Amanda Palmieri Fração

\title{
DIREITO À INVESTIGAÇÃO: ASPECTOS TEÓRICOS E CONSEQUÊNCIAS PRÁTICAS DE SEU RECONHECIMENTO NO \\ PROCESSO PENAL BRASILEIRO
}

\author{
Dissertação de Mestrado - Professor \\ orientador Antonio Magalhães Gomes \\ Filho.
}

FACULDADE DE DIREITO DA UNIVERSIDADE DE SÃO PAULO

SÃO PAULO

2012 
Banca Examinadora: 


\section{ÍNDICE}

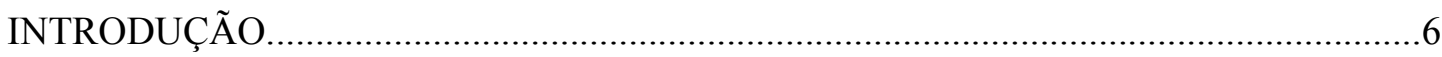

CAPÍTULO I - PROVA PENAL E SUA RELAÇÃO COM O DIREITO À

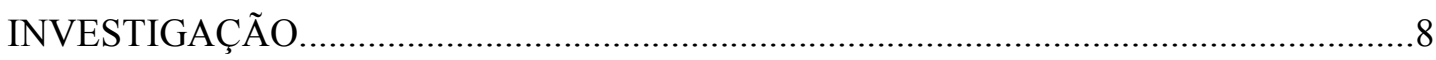

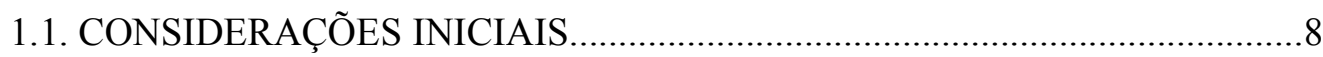

1.2. PROVA: DIFERENTES ACEPÇÕES.............................................................

1.2.1. Prova como demonstração, experimentação e desafio...........................9

1.2.2. Elementos de prova e resultados de prova...........................................10

1.2.3. Provas diretas e provas indiretas.........................................................10

1.2.4. Provas típicas e provas atípicas.............................................................11

1.2.5. Provas constituendas e pré-constituídas..............................................12

1.2.6. Fontes de prova, meios de prova e meios de investigação da

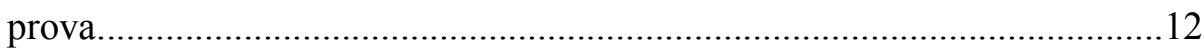

1.2.7. Outras classificações e acepções do vocábulo prova.............................14

1.3. DIREITO À PROVA: PREMISSAS FUNDAMENTAIS...................................15

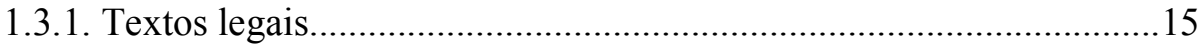

1.3.1.1. Constituição Federal de 1988................................................15

1.3.1.2. Tratados Internacionais de Direitos Humanos......................16

1.3.1.3. Legislação infraconstitucional...............................................20

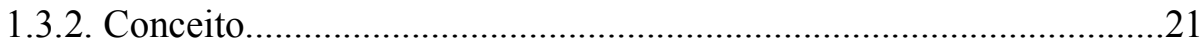

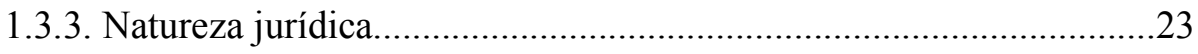

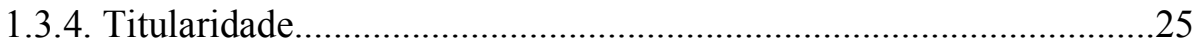

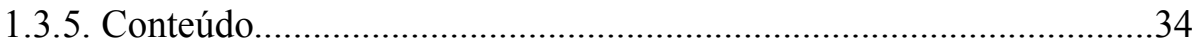

CAPÍTULO II - DIREITO À INVESTIGAÇÃO.............................................................. 
2.1. CONCEITO E FUNDAMENTO.

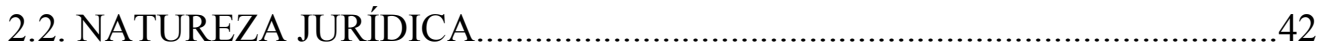

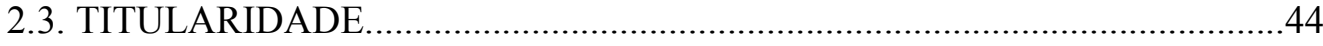

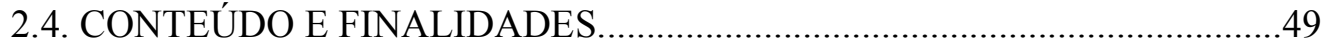

2.5. UTILIZAÇÃO DAS INFORMAÇÕES OBTIDAS NO EXERCÍCIO DO

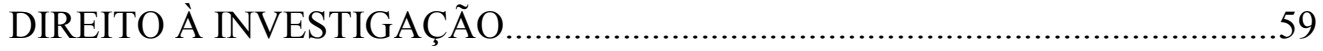

2.5.1. Provas irrepetíveis, cautelares e antecipadas...................................68

2.5.2. Abuso do direito à investigação.......................................................82

2.5.3. Divulgação pela mídia das informações obtidas através das investigações criminais........................................................................90

CAPÍTULO III - DIREITO À INVESTIGAÇÃO: BREVE ANÁLISE DE DIREITO

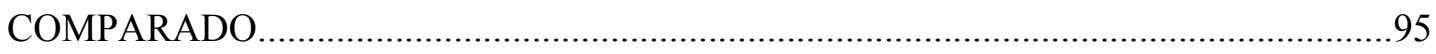

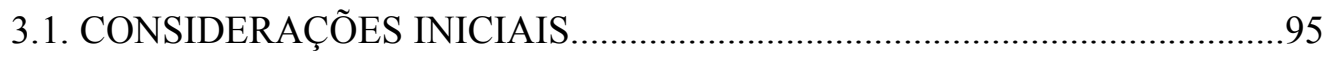

3.2. DIREITO À INVESTIGAÇÃO NOS DIFERENTES SISTEMAS DE

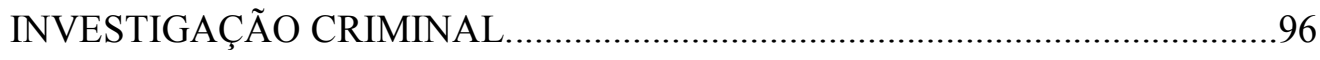

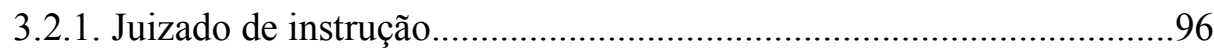

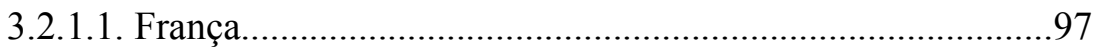

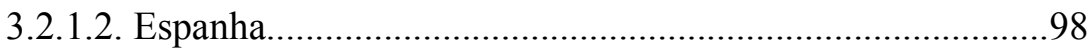

3.2.2. Investigação policial..................................................................99

3.2.2.1. Estados Unidos............................................................... 100

3.2.2.2. Inglaterra................................................................... 103

3.2.3. Investigação ministerial................................................................104

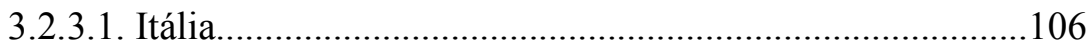

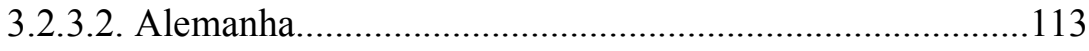

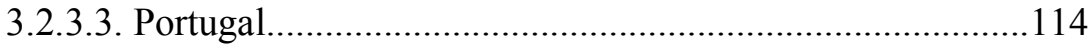

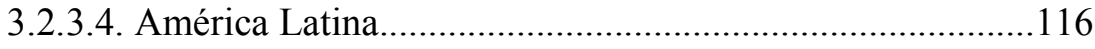


CAPÍTULO IV - DIREITO À INVESTIGAÇÃO E SEU EXERCÍCIO EM FACE DO SISTEMA PROCESSUAL PENAL BRASILEIRO EM VIGOR.......................................119

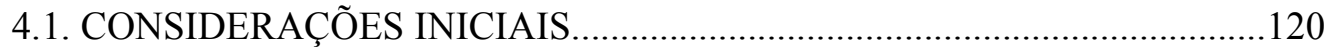

4.2. INVESTIGAÇÃO CRIMINAL E MINISTÉRIO PÚBLICO............................123

4.3. INVESTIGAÇÃO CRIMINAL E DEFESA.....................................................145

4.4. INVESTIGAÇÃO CRIMINAL E VÍTIMA......................................................156

CAPÍTULO V - DIREITO À INVESTIGAÇÃO NO MAIS RECENTE PROJETO DE NOVO CÓDIGO DE PROCESSO PENAL_..................................................................169

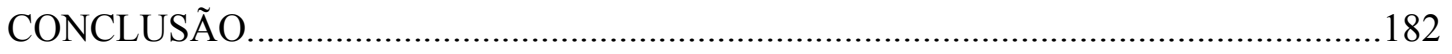

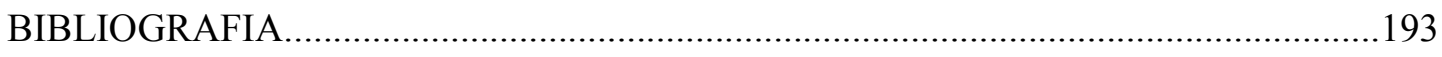

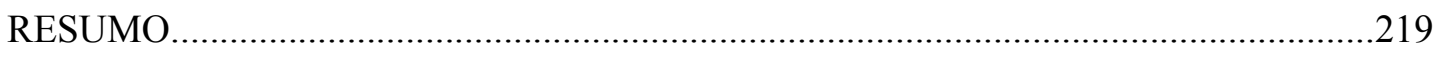




\section{INTRODUÇÃO}

A investigação criminal (também chamada de instrução preliminar ou prévia) normalmente é tratada pela doutrina brasileira meramente como a fase inicial de nossa persecução penal, conhecida como extrajudicial, cuja finalidade primordial é a colheita de informações necessárias à aferição do cabimento ou não da ação penal. Caso a denúncia ou queixa-crime seja oferecida, tem início a segunda fase da persecução penal, designada por judicial, pois relativa ao processo penal propriamente dito.

Ou seja, via de regra, a abordagem que se faz da investigação ressalta seus aspectos procedimentais e sua finalidade de embasar a futura ação penal. Equívoco algum existe no tratamento da matéria sob tais aspectos, sendo, aliás, de grande valia para o processo penal o exame do assunto sob tal viés, dada sua relevância teórica e prática.

O presente estudo, todavia, propõe-se a analisar o tema da investigação sob outro ângulo, com outro enfoque, qual seja o da investigação como um direito das partes, decorrente do próprio direito à prova.

Antes de proceder à análise do direito à investigação em si, faz-se necessário estabelecer algumas premissas teóricas que servirão de base para a melhor compreensão da matéria, a exemplo dos diversos significados que a palavra prova comporta.

Depois de verificadas as possíveis acepções e classificações que cercam o vocábulo prova, o conceito de direito à prova e seus aspectos mais relevantes, em especial seu conteúdo e sua titularidade, serão abordados mais detidamente.

Em seguida, proceder-se-á ao exame do direito à investigação propriamente dito, oportunidade em que serão objeto de análise também sua definição, sua natureza jurídica, bem como os titulares de tal direito e os seus desdobramentos mais relevantes. Nesse sentido, serão analisados diversos aspectos polêmicos relacionados ao direito à investigação, como os possíveis usos e destinações dos elementos de informação colhidos na fase inicial da persecução penal. Neste tópico, far-se-á imprescindível a análise da existência ou não do contraditório em tal etapa do procedimento probatório, bem como de matérias correlatas, como a produção antecipada de provas. Como não poderia deixar de ser, o abuso do direito à investigação e a questão da divulgação pela mídia das informações 
obtidas no seio de uma instrução preliminar também serão abordados, ainda que brevemente. Imperioso mencionar que a análise de todos esses temas considerará não apenas as regras do sistema processual penal brasileiro, mas também o tratamento conferido pelos diversos ordenamentos jurídicos ao direito à investigação, em suas diferentes nuances. Ou seja, o presente trabalho também realizará uma breve análise de direito comparado acerca dos principais aspectos e institutos concernentes ao tema.

Definidas então as bases teóricas que fundamentam o objeto central deste estudo, será alvo de análise mais detida o efetivo exercício do direito à investigação no sistema processual penal brasileiro. Nessa seara, serão abordados e discutidos tanto os dispositivos legais vigentes relacionados à matéria, como sua interpretação doutrinária e jurisprudencial, a fim de traçar um panorama bastante abrangente acerca de como o direito à investigação tem sido assegurado na prática processual penal de nosso País.

Por fim, o mais recente Projeto de novo Código de Processo Penal, que se encontra atualmente em tramitação no Congresso Nacional, também será alvo de abordagem específica, principalmente no que concerne ao direito à investigação.

Em síntese, o presente estudo se dedicará à análise do direito à investigação tanto em seus aspectos teóricos como em seus desdobramentos práticos mais relevantes. 


\section{CAPÍTULO I - PROVA PENAL E SUA RELAÇÃO COM O DIREITO À INVESTIGAÇÃO}

\subsection{CONSIDERAÇÕES INICIAIS}

O estudo do tema prova é dos mais relevantes e caros à ciência processual penal ${ }^{1}$, por variadas razões. As provas permitem a reconstrução dos fatos da maneira mais fidedigna à realidade, apresentando importante função cognitiva ${ }^{2}$, mas não apenas, pois também desempenham papel fundamental na formação do convencimento judicial, sendo sempre destacada sua função persuasiva ou argumentativa ${ }^{3}$.

A atividade probatória também assimila valores e símbolos vigentes na sociedade, constituindo importante ponte nas relações entre o processo e as estruturas sociais ${ }^{4}$. Aliás, a disciplina probatória de um determinado ordenamento jurídico permite até aferir quão democrático ele é, tanto que se afirma que o reconhecimento do direito à prova constitui um dos elementos mais significativos da transição de um regime processual autoritário para um regime processual democrático ${ }^{5}$.

A relevância do tema, sobretudo para o processo penal, em que apenas provas robustas e concludentes podem romper a presunção de inocência que pesa em favor do acusado, é que autoriza sua análise mais aprofundada.

* O modelo de citação adotado neste trabalho foi o franco-italiano, ou simplesmente italiano, tido por EDUARDO CESAR SILVEIRA MARCHI como o método de citação mais adequado à realidade brasileira no âmbito das ciências jurídicas. Cf. Guia de metodologia jurídica (teses, monografias e artigos), Itália, Edizioni del Grifo, 2001, pp. 183-187. Ressalve-se apenas que a citação de juristas brasileiros ao longo do trabalho contará não apenas com seus sobrenomes escritos por extenso, mas também com seus prenomes, em virtude de muitos autores pátrios não serem amplamente conhecidos apenas pelo seu patronímico.

${ }^{1}$ Os juristas italianos GIOVANNI CONSO e VITTORIO GREVI, por exemplo, falam na centralidade do tema para o modelo processual penal acusatório. Cf. Compendio di procedura penale: appendice di aggiornamento, Padova, CEDAM, 2001, p. 276. Também PAOLO TONINI refere-se à prova como o cerne do processo penal. Cf. A prova no processo penal italiano, trad. Alexandra Martins e Daniela Mróz, São Paulo, Revista dos Tribunais, 2002, p. 05. Para JACOBO LÓPEZ BARJA DE QUIROGA, a prova é a pedra angular de todo o sistema de justiça. Cf. Tratado de derecho procesal penal, Navarra, Aranzadi, 2004, p. 900.

${ }^{2}$ Neste ponto, ressalva GUSTAVO HENRIQUE RIGHI IVAHY BADARÓ que, para as teorias que negam a possibilidade de conhecimento verdadeiro dos fatos, por razões ideológicas ou práticas, não há sentido em se falar em prova. Cf. Ônus da prova no processo penal, São Paulo, Revista dos Tribunais, 2003, p. 161.

${ }^{3}$ Cf. GIULIO UBERTIS, La ricerca della verità giudiziale in La conoscenza del fatto nel processo penale, Milano, Giuffrè, 1992, pp. 12-16.

${ }^{4}$ Cf. ANTONIO MAGALHÃES GOMES FILHO, Direito à prova no processo penal, São Paulo, Revista dos Tribunais, 1997, p. 13.

${ }^{5}$ Cf. DELFINO SIRACUSANO, Manuale di diritto processuale penale, vol. 1, Milano, Giuffrè, 1990, p. 395. 


\subsection{PROVA: DIFERENTES ACEPÇÕES}

O termo prova tem a mesma origem etimológica de probo (do latim, probatio e probus), que corresponde às noções de aprovação, correção, confiança, e que se liga à idéia de busca e comunicação da verdade, do conhecimento verdadeiro ${ }^{6}$.

Mas tanto na linguagem comum quanto no mundo jurídico, em especial na ciência processual, o vocábulo prova costuma ser utilizado com diferentes significados. Por tal motivo, é corrente a afirmação de que prova é um termo polissêmico e que, pelo fato de uma mesma palavra ser usada para designar vários objetos, reina certo caos terminológico e grande incoerência no tratamento da matéria ${ }^{7}$.

Como bem observa MICHELLE TARUFFO ao abordar o tema, a prova é um fenômeno complexo e diversificado, o que explica que seu conceito seja problemático, e que suas respectivas classificações sejam inúmeras e pouco rigorosas, além de comumente usadas de maneira bastante flexível ${ }^{8}$.

Mesmo diante da complexidade do tema, e da impossibilidade de adotar uma definição unívoca de prova, ou então de elaborar uma classificação definitiva e que englobe todos os seus possíveis significados, faz-se necessário proceder a algumas distinções e sistematizar melhor a matéria, a fim de torná-la mais clara e compreensível.

Nesse sentido, imperioso enumerar a seguir as principais classificações relativas à prova.

\subsubsection{Prova como demonstração, experimentação e desafio}

Uma primeira importante classificação relativa ao tema é a que distingue prova como demonstração, experimentação e desafio. Na primeira acepção, a prova se destina a estabelecer a veracidade de uma afirmação sobre determinado fato. Na segunda, o vocábulo é empregado para designar a atividade ou procedimento destinado a verificar a correção de certa hipótese. Por fim, na terceira acepção, o significado de prova equivaleria

\footnotetext{
${ }^{6}$ Cf. ANTONIO MAGALHÃES GOMES FILHO, Notas sobre a terminologia da prova (reflexos no processo penal brasileiro) in Estudos em homenagem à Professora Ada Pellegrini Grinover, org. Flávio Luiz Yarshell e Maurício Zanóide de Moraes, São Paulo, DPJ, 2005, p. 305.

7 Cf. MARINA GASCÓN ABELLÁN, Los hechos en el derecho - Bases argumentales de la prueba, Barcelona, Marcial Pons, Ediciones Jurídicas e Sociales, 1999, p. 83.

${ }^{8}$ Cf. La prueba de los hechos, Madrid, Ed. Trotta, 2002, pp. 439-440.
} 
ao de teste ou competição a ser superada para ver reconhecida uma determinada qualidade ${ }^{9}$.

\subsubsection{Elementos de prova e resultados de prova}

Outra relevante distinção concernente ao tema diz respeito aos elementos de prova e aos resultados da prova. Ao utilizar-se a primeira expressão, que no sistema americano da Common Law equivaleria à idéia de "evidence", está-se a fazer referência aos dados objetivos que confirmam ou negam uma afirmação relativa a um fato que interessa à causa. De outro lado, ao usar a segunda locução referida, que corresponderia à noção de "proof”, em inglês, está-se a referir à própria conclusão extraída dos diferentes elementos de prova colhidos ${ }^{10}$.

\subsubsection{Provas diretas e provas indiretas}

Também é bastante comum a classificação das provas em diretas e indiretas. MARINA GASCÓN ABELLÁN aponta três critérios que permitem diferenciar uma classe da outra ${ }^{11}$, mas, de maneira resumida, pode-se dizer que a prova direta é a que permite conhecer o fato por uma única operação inferencial, ou seja, o fato que se quer provar surge direta e espontaneamente, sem mediação ou necessidade de raciocínio, ao passo que, na prova indireta, é necessário fazer ao menos duas inferências para se conhecer o fato a ser provado, este não surge diretamente. Ou seja, à prova indireta corresponderia a idéia de prova indiciária, ou apenas indício ${ }^{12}$.

Explica GUSTAVO HENRIQUE RIGHI IVAHY BADARÓ que na prova direta, há um contato imediato entre o juiz e o fato a ser provado, nada se interpõe entre

\footnotetext{
9 Aludida classificação é trazida tanto por MICHELLLE TARUFFO na obra La prueba de los hechos, Madrid, Ed. Trotta, 2002, pp. 415-416, como por ANTONIO MAGALHÃES GOMES FILHO em seu artigo Notas sobre a terminologia da prova (reflexos no processo penal brasileiro) in Estudos em homenagem à Professora Ada Pellegrini Grinover, org. Flávio Luiz Yarshell e Maurício Zanóide de Moraes, São Paulo, DPJ, 2005, p. 305.

${ }^{10}$ Cf. ANTONIO MAGALHÃES GOMES FILHO, Notas sobre a terminologia da prova (reflexos no processo penal brasileiro) in Estudos em homenagem à Professora Ada Pellegrini Grinover, org. Flávio Luiz Yarshell e Maurício Zanóide de Moraes, São Paulo, DPJ, 2005, pp. 307-308.

${ }^{11}$ Cf. Los hechos en el derecho - Bases argumentales de la prueba, Barcelona, Marcial Pons, Ediciones Jurídicas e Sociales, 1999, pp. 87-88.

12 Cf. ANTONIO MAGALHÃES GOMES FILHO, Notas sobre a terminologia da prova (reflexos no processo penal brasileiro) in Estudos em homenagem à Professora Ada Pellegrini Grinover, org. Flávio Luiz Yarshell e Maurício Zanóide de Moraes, São Paulo, DPJ, 2005, p. 310.
} 
estes. Já na prova indireta, há uma separação entre o juiz e o fato a ser provado, e o contato entre ambos é estabelecido por um fato intermediário ${ }^{13}$.

Para LUIGI PAOLO COMOGLIO, CORRADO FERRI e MICHELLE TARUFFO, na verdade, prova direta seria a que versa sobre o fato principal da causa, enquanto a indireta seria aquela que tem por objeto imediato um fato secundário ${ }^{14}$. Semelhante é o posicionamento de NICOLA FRAMARINO DEI MALATESTA, para quem a prova direta diz respeito ao delito em si, ao passo que a prova indireta se relaciona a coisa diversa do crime ${ }^{15}$.

\subsubsection{Provas típicas e provas atípicas}

As provas também podem ser classificadas com base no fato de estarem ou não expressamente previstas e disciplinadas em lei. Nesse sentido, fala-se em provas típicas quando as mesmas se encontram catalogadas e reguladas em texto legal e, de outro lado, em provas atípicas, quando as mesmas não encontram referência normativa ${ }^{16}$. Para ANTONIO SCARANCE FERNANDES, porém, prova típica é aquela prevista em lei e dotada de procedimento próprio para sua realização, enquanto prova atípica é aquela que, encontrando ou não previsão legal, é destituída de procedimento próprio para sua efetivação $^{17}$.

Neste ponto, oportuno mencionar que as provas atípicas não se confundem com as provas irrituais, que são aquelas provas típicas produzidas sem a observância de seu procedimento probatório, nem com as provas anômalas, que são provas típicas, utilizadas ou para fins diversos daqueles que lhes são próprios, ou para fins característicos de outras provas típicas ${ }^{18}$.

\footnotetext{
${ }^{13}$ Cf. Onus da prova no processo penal, São Paulo, Revista dos Tribunais, 2003, p. 163.

${ }^{14} \mathrm{Cf}$. Lezioni sul processo civile, $2^{\mathrm{a}}$ ed., Bologna, Il Mulino, 1998, p. 611.

${ }^{15}$ Cf. A lógica das provas em matéria criminal, trad. Waleska Girotto Silverberg, vol. I, Conan Editora, 1995 , p. 122.

${ }^{16}$ Cf. ANTONIO MAGALHÃES GOMES FILHO, Notas sobre a terminologia da prova (reflexos no processo penal brasileiro) in Estudos em homenagem à Professora Ada Pellegrini Grinover, org. Flávio Luiz Yarshell e Maurício Zanóide de Moraes, São Paulo, DPJ, 2005, p. 314.

${ }^{17}$ Cf. Prova e sucedâneos da prova no processo penal, Revista Brasileira de Ciências Criminais, $\mathrm{n}^{\circ}$ 66, vol. 15, 2007, p. 199.

${ }^{18}$ Cf. GUSTAVO HENRIQUE IVAHY BADARÓ, Provas atípicas e provas anômalas: inadmissibilidade da substituição da prova testemunhal pela juntada de declarações escritas de quem poderia ser testemunha in Estudos em homenagem à Professora Ada Pellegrini Grinover, org. Flávio Luiz Yarshell e Maurício Zanóide de Moraes, São Paulo, DPJ, 2005, pp. 344-345. Ainda sobre o tema, recomenda-se a leitura da obra de GUILHERME MADEIRA DEZEM, Da prova penal: tipo processual, provas típicas e atipicas, Campinas, Millenium, 2008.
} 


\subsubsection{Provas constituendas e pré-constituídas}

Numa distinção bastante simples, é possível afirmar que as provas constituendas são aquelas formadas durante o processo ${ }^{19}$, através de procedimentos probatórios expressamente previstos em lei, enquanto as provas pré-constituídas têm existência anterior ao processo, são formadas fora do mesmo. Um exemplo típico de prova pré-constituída é o documento, produzido fora do processo e depois nele introduzido ${ }^{20}$.

\subsubsection{Fontes de prova, meios de prova e meios de investigação da prova}

Para os fins deste trabalho, a distinção entre fontes de prova, meios de prova e meios de investigação de prova talvez seja a mais relevante ${ }^{21}$.

Fontes de prova seriam as pessoas ou coisas através das quais se pode conseguir a prova, ou seja, a expressão designa tudo aquilo que é idôneo a fornecer resultado apreciável para a decisão judicial. Disso decorre a distinção que costuma ser feita entre fontes pessoais (testemunhas, peritos, acusado e vítima) e fontes reais de prova (documentos amplamente considerados) $^{22}$. GUSTAVO HENRIQUE RIGHI IVAHY BADARÓ chama ainda atenção para o fato de que as fontes de prova são anteriores ao processo, mas podem ser levadas à apreciação judicial, através de sua introdução no processo pelos meios de prova ${ }^{23}$.

A propósito, os meios de prova consistem nas atividades ou instrumentos por meio dos quais os elementos probatórios são introduzidos e fixados no processo $^{24}$. LUIGI PAOLO COMOGLIO, CORRADO FERRI e MICHELLE TARUFFO não se

${ }^{19}$ Cf. CÂNDIDO RANGEL DINAMARCO, Instituições de Direito Processual Civil, vol. III, São Paulo, Malheiros, 2001, pp. 93-94.

${ }^{20}$ Cf. LUIGI PAOLO COMOGLIO, CORRADO FERRI E MICHELLE TARUFFO, Lezioni sul processo civile, $2^{\mathrm{a}}$ ed., Bologna, Il Mulino, 1998, p. 613.

${ }_{21}$ Aludida classificação foi empreendida, entre outros autores, por ANTONIO MAGALHÃES GOMES FILHO. Cf. Notas sobre a terminologia da prova (reflexos no processo penal brasileiro) in Estudos em homenagem à Professora Ada Pellegrini Grinover, org. Flávio Luiz Yarshell e Maurício Zanóide de Moraes, São Paulo, DPJ, 2005, pp. 308-309.

${ }^{22}$ Cf. ANTONIO MAGALHÃES GOMES FILHO, Notas sobre a terminologia da prova (reflexos no processo penal brasileiro) in Estudos em homenagem à Professora Ada Pellegrini Grinover, org. Flávio Luiz Yarshell e Maurício Zanóide de Moraes, São Paulo, DPJ, 2005, p. 308.

${ }^{23} \mathrm{Cf}$. Ônus da prova no processo penal, São Paulo, Revista dos Tribunais, 2003, p. 166.

${ }^{24}$ Cf. ANTONIO MAGALHÃES GOMES FILHO, Notas sobre a terminologia da prova (reflexos no processo penal brasileiro) in Estudos em homenagem à Professora Ada Pellegrini Grinover, org. Flávio Luiz Yarshell e Maurício Zanóide de Moraes, São Paulo, DPJ, 2005, p. 308. Conceito muito semelhante de meios de prova é trazido por GUSTAVO HENRIQUE IVAHY BADARÓ. Cf. Ônus da prova no processo penal, São Paulo, Revista dos Tribunais, 2003, p. 166. 
afastam de tal conceito, ao afirmar que os meios de prova correspondem aos instrumentos e procedimentos cognitivos que servem para o acertamento dos fatos sobre os quais versa o processo $^{25}$. Resume MARINA GASCÓN ABELLÁN que meio de prova é tudo aquilo que permite conhecer os fatos relevantes da causa ${ }^{26}$.

Dos meios de prova distinguem-se os meios de pesquisa ou de investigação da prova: estes dizem respeito a determinados procedimentos, via de regra extraprocessuais, destinados a obter as já referidas fontes de prova. Ou seja, os meios de investigação não são, por si só, fontes de conhecimento, mas permitem a aquisição de coisas materiais, traços ou declarações dotadas de força probatória ${ }^{27}$.

O Código de Processo Penal italiano, de 1988, disciplina em títulos diferentes os meios de prova, a exemplo dos documentos, testemunhos e perícias, dos meios de obtenção ou investigação de provas, como as inspeções, buscas e apreensões, interceptações de conversas telefônicas, entre outros. Ao tratar do tema, observa PAOLO TONINI que várias características permitem diferenciar os meios de prova dos meios de investigação, entre as quais o fato de que os meios de prova só podem ser produzidos perante o juiz, ao passo que os meios de investigação da prova podem ser produzidos pela polícia ou pelo Ministério Público, tendo os mesmos como destinatários ${ }^{28}$.

Outro importante traço discriminador entre os meios de prova e os meios de investigação reside no fato de que os primeiros devem sempre observar o contraditório, mesmo na fase investigatória, ao passo os últimos podem contar com o chamado "fator surpresa", sem o que seria inviável a obtenção de determinadas fontes de prova na fase inicial da persecução penal ${ }^{29}$. É o que ocorre com as interceptações telefônicas, buscas e apreensões, entre outros. Há, porém, meios de pesquisa que prescindem do referido fator surpresa para que sejam eficazes; a quebra de sigilo bancário ou fiscal é um exemplo.

${ }^{25} \mathrm{Cf}$. Lezioni sul processo civile, $2^{\mathrm{a}}$ ed., Bologna, Il Mulino, 1998, pp. 610-611.

${ }^{26}$ Cf. Los hechos en el derecho - Bases argumentales de la prueba, Barcelona, Marcial Pons, Ediciones Jurídicas e Sociales, 1999, p. 84.

27 Cf. ANTONIO MAGALHÃES GOMES FILHO, Notas sobre a terminologia da prova (reflexos no processo penal brasileiro) in Estudos em homenagem à Professora Ada Pellegrini Grinover, org. Flávio Luiz Yarshell e Maurício Zanóide de Moraes, São Paulo, DPJ, 2005, p. 309.

${ }^{28}$ Cf. A prova no processo penal italiano, trad. Alexandra Martins e Daniela Mróz, São Paulo, Revista dos Tribunais, 2002, p. 242.

29 Cf. ANTONIO MAGALHÃES GOMES FILHO, Notas sobre a terminologia da prova (reflexos no processo penal brasileiro) in Estudos em homenagem à Professora Ada Pellegrini Grinover, org. Flávio Luiz Yarshell e Maurício Zanóide de Moraes, São Paulo, DPJ, 2005, p. 309. 


\subsubsection{Outras classificações e acepções do vocábulo prova}

De suma importância afigura-se a menção ao significado que deve ser atribuído à locução "objeto de prova". Costuma-se afirmar, de modo bastante simplista, que o objeto da prova é meramente o fato relacionado à causa submetida à apreciação judicial $^{30}$. No entanto, parece mais acertado o entendimento professado por alguns juristas segundo o qual o objeto da prova é na verdade não o fato em si, mas a afirmação, a alegação feita sobre o fato ${ }^{31}$.

Nesse sentido, explica ANTONIO MAGALHÃES GOMES FILHO que “o fato, como fenômeno do mundo real, somente poderia ser constatado no próprio momento em que se verifica; não é possível, portanto, provar um acontecimento passado, mas somente demonstrar se uma afirmação sobre este é ou não verdadeira ${ }^{, 32}$.

Ou seja, no processo penal, a atividade probatória tem por objeto as alegações feitas pelas partes acerca do fato criminoso e de outras circunstâncias correlatas relevantes. Não são os fatos em si que se consideram provados ou não, mas sim as alegações formuladas acerca desses mesmos fatos.

Válido ainda mencionar que, principalmente na Itália, costuma-se utilizar a expressão "argumento de prova" para designar os elementos ou dados de convencimento aos quais se atribui um valor probatório inferior, insuficientes para decidir, mas que podem reforçar o raciocínio feito pelo magistrado com base em verdadeiros elementos de prova ${ }^{33}$. O Código de Processo Penal italiano alude expressamente ao referido argumento de prova em um de seus dispositivos (art. 116, $\S 2^{\circ}$ ), permitindo ao juiz extraí-lo das respostas dadas

\footnotetext{
${ }^{30}$ Para GUILHERME DE SOUZA NUCCI, por exemplo, “o objeto da prova, primordialmente, são os fatos, que as partes pretendem demonstrar”. Cf. Código de processo penal comentado, 9 ${ }^{\mathrm{a}}$ ed., São Paulo, Revista dos Tribunais, 2009, p. 348. No mesmo sentido é o posicionamento de PAULO RANGEL. Cf. Direito processual penal, $10^{\mathrm{a}}$ ed., Rio de Janeiro, Lumen Juris, 2005, p. 414.

${ }^{31}$ Cf. GUSTAVO HENRIQUE IVAHY BADARÓ, Ônus da prova no processo penal, São Paulo, Revista dos Tribunais, 2003, p. 159.

32 Cf. ANTONIO MAGALHÃES GOMES FILHO, Notas sobre a terminologia da prova (reflexos no processo penal brasileiro) in Estudos em homenagem à Professora Ada Pellegrini Grinover, org. Flávio Luiz Yarshell e Maurício Zanóide de Moraes, São Paulo, DPJ, 2005, p. 317. Complementa ainda o autor que não é possível dissociar a pesquisa probatória do contraditório processual, "pois o seu objeto não são simples fatos externos - realidades independentes do sujeito -, mas fatos interpretados, pois constituem resultado de uma subsunção em uma classe de fatos relevantes para o direito, segundo a perspectiva de quem os afirma no processo".

${ }^{33}$ Cf. LUIGI PAOLO COMOGLIO, CORRADO FERRI E MICHELLE TARUFFO, Lezioni sul processo civile, $2^{\mathrm{a}}$ ed., Bologna, Il Mulino, 1998, p. 612.
} 
pelas partes no interrogatório, de sua recusa em consentir inspeções, ou mesmo de sua conduta no curso do processo ${ }^{34}$.

Também é digna de nota a locução "sucedâneo de prova", usada para nomear elementos de informação que não derivam de meios de prova propriamente ditos, mas sim decorrem de conhecimentos obtidos de forma diversa e que podem ser considerados na formação do convencimento judicial ${ }^{35}$. Sobre o assunto, observa ANTONIO SCARANCE FERNANDES que a expressão sucedâneos da prova não é comumente utilizada nos países ibero-americanos, embora os fenômenos de que os sucedâneos tratam sejam realidades nos processos criminais da região ${ }^{36}$.

Muitas outras classificações e definições relacionadas ao vocábulo prova poderiam ser ainda aqui enumeradas. No entanto, para os fins a que este trabalho se propõe, as distinções e esclarecimentos até o momento realizados mostram-se suficientes. Resta apenas analisar com maior profundidade e cuidado o significado da expressão direito à prova, e todos os aspectos a ela relacionados, principalmente sua natureza jurídica, sua titularidade e seu conteúdo. É possível adiantar, desde logo, que neste último é que insere o direito à investigação, objeto central deste trabalho.

\subsection{DIREITO À PROVA: PREMISSAS FUNDAMENTAIS}

Para uma correta análise do significado da expressão "direito à prova" e de todas as implicações decorrentes de seu reconhecimento, necessário se faz examinar previamente quais textos legais do ordenamento jurídico brasileiro em vigência asseguram tal direito e em que medida.

\subsubsection{Textos legais}

\subsubsection{Constituição Federal de 1988}

\footnotetext{
${ }^{34}$ Cf. ANTONIO MAGALHÃES GOMES FILHO, Notas sobre a terminologia da prova (reflexos no processo penal brasileiro) in Estudos em homenagem à Professora Ada Pellegrini Grinover, org. Flávio Luiz Yarshell e Maurício Zanóide de Moraes, São Paulo, DPJ, 2005, p. 312-313.

${ }^{35}$ Cf. ANTONIO MAGALHÃES GOMES FILHO e GUSTAVO HENRIQUE RIGHI IVAHY BADARÓ, Prova e sucedâneos de prova no processo penal brasileiro in Revista Brasileira de Ciências Criminais, São Paulo, Revista dos Tribunais, $n^{\circ}$ 65, março-abril de 2007, p. 177.

${ }^{36}$ Cf. Prova e sucedâneos da prova no processo penal, Revista Brasileira de Ciências Criminais, $\mathrm{n}^{\circ} 66$, vol. 15, 2007, p. 234.
} 
A Lei Maior de nosso País não assegura expressamente em seu extenso rol de direitos e garantias fundamentais o direito à prova. Nenhum dos incisos do artigo $5^{\circ}$ da Constituição Federal de 1988 contempla a locução referida, mas nem por isso se pode afirmar que o diploma não assegura o direito à prova. Entende-se que tal direito foi amparado pela Constituição como decorrência lógica de outros direitos expressamente previstos, quais sejam o direito ao devido processo legal (art. $5^{\circ}$, LIV), ao contraditório e à ampla defesa, com os meios e recursos a ela inerentes (art. $\left.5^{\circ}, \mathrm{LV}\right)^{37}$ e à presunção de inocência (art. 5, LVII), já que apenas na hipótese de comprovação da autoria e materialidade de um delito se pode romper a presunção de inocência que existe em favor do acusado para declará-lo culpado, além do que tem o imputado o direito de defender-se provando da acusação que lhe é feita ${ }^{38}$.

\section{Observam ADA PELLEGRINI GRINOVER, ANTONIO SCARANCE} FERNANDES e ANTONIO MAGALHÃES GOMES FILHO que o direito à prova está intimamente ligado ao contraditório e ao exercício do direito de ação e de defesa ${ }^{39}$. Entendido o primeiro como ciência bilateral dos atos e termos do processo, com a possibilidade de impugná- $\operatorname{los}^{40}$, tem-se que tanto ao autor como ao réu são asseguradas posições ativas, de vantagem, a fim de que possam influir no desenvolvimento e no resultado do processo.

Entre as referidas posições jurídicas ativas encontra-se a possibilidade de formular alegações e de demonstrar que as mesmas são verdadeiras, garantindo assim a justiça do provimento jurisdicional. Ou seja, às partes é assegurado o direito à prova tanto como decorrência do contraditório como do exercício dos direitos de ação e de defesa.

\subsubsection{Tratados Internacionais de Direitos Humanos}

Os mais importantes textos internacionais sobre direitos humanos asseguram, de uma forma ou de outra, o direito à prova. Serão aqui objeto de análise os principais diplomas internacionais incorporados ao ordenamento jurídico brasileiro. Não

\footnotetext{
${ }^{37}$ Cf. ADA PELLEGRINI GRINOVER, A marcha do processo, Rio de Janeiro, Forense Universitária, 2000, p. 451.

${ }^{38}$ Cf. ANTONiO MAGAlHÃes GOMES FILHO, Direito à prova no processo penal, São Paulo, Revista dos Tribunais, 1997, p. 80.

${ }^{39} \mathrm{Cf}$. As nulidades no processo penal, $11^{\mathrm{a}}$ ed., São Paulo, Revista dos Tribunais, 2009, p. 113.

${ }^{40}$ Esta é a definição clássica de contraditório trazida por JOAQUIM CANUTO MENDES DE ALMEIDA, que ressalta a necessidade de informação e possibilidade de reação para que o contraditório se faça presente. Cf. Princípios fundamentais do processo penal, São Paulo, Revista dos Tribunais, 1973, p. 82.
} 
custa, porém, mencionar, que a Convenção Européia de Direitos Humanos contém previsão semelhante à verificada nos tratados de que o Brasil é signatário, e que garante ao acusado o direito de "inquirir ou fazer inquirir as testemunhas de acusação, e obter o comparecimento e inquirição das testemunhas de defesa nas mesmas condições que as da acusação” (art. 6º 3, letra d).

Pois bem, com a incorporação ao ordenamento jurídico brasileiro do Pacto Internacional de Direitos Civis e Políticos de 1966, e da Convenção Americana de Direitos Humanos (ou Pacto de São José da Costa Rica) de 1969, entende-se que o direito à prova foi consagrado em definitivo em nosso País ${ }^{41}$, já que o primeiro diploma garante em seu artigo 14.3.e) o direito aos acusados de "interrogar ou fazer interrogar as testemunhas da acusação e de obter o comparecimento e o interrogatório das testemunhas de defesa nas mesmas condições de que dispõe as de acusação", ao passo que o último, na mesma esteira do diploma anterior, assegura à defesa em seu artigo 8.2.f) o direito de "inquirir as testemunhas presentes no tribunal e de obter o comparecimento, como testemunhas ou peritos, de outras pessoas que possam lançar luz sobre os fatos".

Com base nos referidos dispositivos, há quem sustente que, na verdade, os tratados internacionais em questão asseguraram expressamente não o direito à prova, mas sim o direito ao confronto. Este, considerado também um direito fundamental do acusado, abrangeria os direitos à produção da prova testemunhal em audiência pública, à presença na produção da prova testemunhal, à produção de tal prova na presença do julgador do mérito da causa, à imposição às testemunhas do compromisso de dizer a verdade, ao conhecimento da verdadeira identidade das fontes de prova testemunhal, e à comunicação reservada, livre e ininterrupta com o defensor técnico, durante o depoimento das testemunhas ${ }^{42}$.

Para DIOGO MALAN, por exemplo, o artigo 14.3.e) do Pacto Internacional de Direitos Civis e Políticos de 1966, e o art. 8.2.f) da Convenção Americana de Direitos Humanos (ou Pacto de São José da Costa Rica) de 1969 consagram o "right of

${ }^{41}$ Cf. ANTONIO MAGALHÃES GOMES FILHO, Direito à prova no processo penal, São Paulo, Revista dos Tribunais, 1997, p. 82.

${ }^{42}$ Cf. DIOGO MALAN, Processo penal de partes: "right of confrontation" na produção da prova oral, Tese de doutorado apresentada à Faculdade de Direito da Universidade de São Paulo, São Paulo, 2008, p. 100. 
confrontation" aos acusados, ainda que o último tratado, aparentemente, circunscreva o direito à mera inquirição das testemunhas presentes no tribunal ${ }^{43}$.

A redação dos referidos dispositivos dos tratados internacionais em análise, de fato, pode ensejar a interpretação segundo a qual apenas o direito ao confronto foi pelos mesmos assegurado. Afinal, a alusão expressa à matéria probatória cinge-se, basicamente, ao direito de participar da inquirição das testemunhas, e de confrontá-las, com todas as prerrogativas daí decorrentes.

No entanto, numa interpretação mais abrangente dos artigos 14.3.e) do Pacto Internacional de Direitos Civis e Políticos, e do art. 8.2.f) da Convenção Americana de Direitos Humanos, e consentânea com os outros direitos e garantias assegurados por estes tratados, entre os quais o direito a um justo processo, é possível afirmar que, mais do que o direito ao confronto, os dispositivos reconheceram um verdadeiro direito à prova, em seu alcance mais amplo: a todas as partes do processo, e em relação a todos os meios de prova e de investigação, aí incluídas não apenas as fontes pessoais mas também as reais.

Lembre-se que os direitos humanos devem ser interpretados da maneira mais favorável ao indivíduo ${ }^{44}$, além do que a escolha da interpretação que ofereça o maior grau de proteção à pessoa é expressamente imposta pelo art. 29 da Convenção Americana de Direitos Humanos, e pelo artigo $5^{\circ}$ do Pacto Internacional de Direitos Civis e Políticos.

Neste sentido, acrescenta ANTONIO MAGALHÃES GOMES FILHO que "a referência dos textos unicamente a testemunhas (salvo a menção da Convenção Americana a peritos) não deve levar a entender-se excluída a garantia em relação aos demais meios de prova, pois as redações adotadas estão certamente influenciadas pela tradição anglo-americana, em que há predominância da via testemunhal para introdução de elementos informativos no processo, inclusive no que toca aos peritos (expert witness); ademais, tratando-se (...) de atributo essencial à noção de justo processo, é induvidosamente aplicável a qualquer tipo de prova, ${ }^{, 45}$.

\footnotetext{
${ }^{43}$ Cf. Processo penal de partes: "right of confrontation" na produção da prova oral, Tese de doutorado apresentada à Faculdade de Direito da Universidade de São Paulo, São Paulo, 2008, p. 100.

${ }^{44}$ Cf. INGO WOLFGANG SARLET, A eficácia dos direitos fundamentais, $9^{\mathrm{a}} \mathrm{ed}$., Porto Alegra, Livraria do Advogado, 2008, p. 152.

${ }^{45}$ Cf. Direito à prova no processo penal, São Paulo, Revista dos Tribunais, 1997, p. 74.
} 
E, neste ponto, importa ressaltar que, por força do disposto no art. $5^{\circ}, \S 2^{\circ}$, da Constituição Federal ${ }^{46}$, há quem sustente que as garantias previstas nos aludidos tratados internacionais ratificados pelo Brasil e incorporados ao nosso ordenamento têm estatura de direitos fundamentais, o que na verdade só teria tornado expresso o direito à prova assegurado implicitamente em nosso sistema, vez que decorrente de outros direitos e garantias previstos na Carta Magna ${ }^{47}$.

No entanto, é imperioso mencionar que existem várias correntes interpretativas relativas à hierarquia dos tratados internacionais de direitos humanos: defende-se tanto a hierarquia supraconstitucional destes tratados, como a hierarquia constitucional, a hierarquia infraconstitucional mas supralegal, e a paridade hierárquica entre tratado e lei federal ${ }^{48}$.

A jurista FLÁVIA PIOVESAN, por exemplo, sustentava desde antes da Emenda Constitucional $n^{\circ} 45 / 2004$ (que acrescentou o $\S 3^{\circ}$ ao art. $5^{\circ}$ da Carta Magna) que os direitos enunciados nos tratados internacionais de que o Brasil é signatário têm hierarquia de norma constitucional ${ }^{49}$.

Com a Reforma do Judiciário, e o consequente acréscimo do aludido $\S 3^{\circ}$ ao art. $5^{\circ}$ do texto constitucional ${ }^{50}$, passou-se a prever que os tratados e convenções internacionais sobre direitos humanos aprovados com quorum qualificado, idêntico ao exigido para a aprovação de emendas constitucionais, têm a natureza destas.

Para FLÁVIA PIOVESAN, a mudança apenas permitiu o surgimento de duas categorias de tratados internacionais de direitos humanos, quais sejam a dos tratados apenas materialmente constitucionais (já que por força do disposto no art. $5^{\circ}, \S 2^{\circ}$ da Constituição, todos os tratados internacionais de direitos humanos apresentam tal natureza), e os tratados material e formalmente constitucionais (que são aqueles aprovados

\footnotetext{
${ }^{46}$ Eis o que estatui o aludido dispositivo: "Os direitos e garantias expressos nesta Constituição não excluem outros decorrentes do regime e dos princípios por ela adotados, ou dos tratados internacionais em que a República Federativa do Brasil seja parte”.

${ }^{47}$ Cf. ANTONIO MAGAlHÃES GOMES FILHO, Direito à prova no processo penal, São Paulo, Revista dos Tribunais, 1997, p. 82.

${ }^{48}$ Cf. FLÁVIA PIOVESAN, Reforma do Judiciário e direitos humanos in Reforma do Judiciário analisada e comentada - Emenda Constitucional 45/2004, coord. André Ramos Tavares, Pedro Lenza e Pietro de Jesús Alarcón, São Paulo, Método, 2005, p. 69, e INGO WOLFGANG SARLET, A eficácia dos direitos fundamentais, $9^{\mathrm{a}}$ ed., Porto Alegra, Livraria do Advogado, 2008, pp. 150-152.

${ }^{49}$ Cf. A incorporação, a hierarquia e o impacto dos tratados internacionais de proteção dos direitos humanos no direito brasileiro in $\mathrm{O}$ sistema interamericano de proteção dos direitos humanos e o direito brasileiro, coord. Luiz Flávio Gomes e Flávia Piovesan, São Paulo, Revista dos Tribunais, 2000, p. 160.

${ }^{50}$ Dispõe o art. $5^{\circ}, \S 3^{\circ}$ da Constituição Federal de 1988 que "os tratados e convenções internacionais sobre direitos humanos que foram aprovados, em cada Casa do Congresso Nacional, em dois turnos, por três quintos dos votos dos respectivos membros, serão equivalentes às emendas constitucionais".
} 
com o quorum qualificado previsto no art. $5^{\circ}, \S 3^{\circ}$ do texto constitucional). A principal diferença entre eles residiria no regime jurídico aplicável à denúncia (ato unilateral através do qual um Estado se retira de um tratado): os tratados materialmente constitucionais são suscetíveis de denúncia, em virtude das peculiaridades do regime de direito internacional público, ao passo que os tratados material e formalmente constitucionais não são passíveis de denúncia, porque receberam expressamente assento no texto da Constituição ${ }^{51}$.

Já para ALEXANDRE DE MORAES, a introdução do $\S 3^{\circ}$ no art. $5^{\circ}$ da Constituição apenas permitiu ao Congresso Nacional optar por incorporar os tratados internacionais em nosso ordenamento jurídico com o status de emenda constitucional, ou então com status ordinário, de norma infraconstitucional, nos termos do art. 49, I, do texto ${ }^{52}$.

No Supremo Tribunal Federal, embora alguns Ministros defendam a hierarquia constitucional dos tratados internacionais de direitos humanos ${ }^{53}$, decisão tomada pelo Tribunal Pleno em 2008 asseverou o status normativo supralegal dos tratados internacionais de direitos humanos aprovados sem o quorum qualificado previsto no art. $5^{\circ}$, $\S 3^{\circ}$ da Constituição: referidos diplomas estariam abaixo da Constituição na pirâmide normativa, mas acima da legislação interna ${ }^{54}$. Tal seria então a qualificação da Convenção Americana de Direitos Humanos e do Pacto Internacional de Direitos Civis e Políticos, ambos aprovados antes da entrada em vigor da Emenda Constitucional nº 45/2004.

\subsubsection{Legislação infraconstitucional}

No plano infraconstitucional, o principal diploma vigente, qual seja o Código de Processo Penal (CPP), também assegura à acusação e à defesa o direito à prova, em seus mais variados aspectos.

Apenas para citar alguns exemplos, as partes podem especificar as provas que pretendem produzir (artigos 396-A e 406, $\S 3^{\circ}$ do CPP), apresentar documentos em qualquer fase do processo, salvo os casos expressos em lei (art. 231 do CPP), indicar

${ }^{51}$ Cf. Reforma do Judiciário e direitos humanos in Reforma do Judiciário analisada e comentada - Emenda Constitucional 45/2004, coord. André Ramos Tavares, Pedro Lenza e Pietro de Jesús Alarcón, São Paulo, Método, 2005, pp. 72-75.

${ }^{52}$ Cf. Direito constitucional, 24a ed., São Paulo, Atlas, 2009, p. 692-693, e p. 739.

${ }^{53}$ Cf. STF, HC 96772/SP, Relator Min. Celso De Mello, Segunda Turma, j. 09/06/2009, HC 90450/MG, Relator Min. CELSO DE MELLO, Segunda Turma, j. 23/09/2008, entre outros.

${ }^{54}$ Cf. STF, RE 349703/RS, Relator Min. Carlos Britto, Tribunal Pleno, j. 03/12/2008. 
testemunhas e a elas formular perguntas (artigos 41, 396-A, 406, $\S \S 2^{\circ}$ e $3^{\circ}, 532$ e 212 do CPP), requerer a realização de diligências (art. 410 do CPP) bem como esclarecimentos ao perito (artigos $400, \S 2^{\circ}$ e $411, \S 1^{\circ}$ do CPP), entre outros.

Como se vê, vários dispositivos do Código de Processo Penal vigente asseguram às partes o direito de requerer e produzir provas no curso do processo. No entanto, o direito à prova não se resume a tais prerrogativas, é mais abrangente, o que restará melhor explicitado adiante, quando da análise do conteúdo do direito à prova. Antes disso, imperioso analisar seu conceito, sua natureza jurídica e seus titulares.

\subsubsection{Conceito}

Como se sabe, nas relações jurídicas de direito material ou processual, há tanto posições ativas como negativas. As primeiras, também tidas por favoráveis, visam a realizar um determinado interesse de seu titular, ao passo que as segundas, ditas desfavoráveis, destinam-se a realizar certo interesse de outrem em face do titular da posição jurídica ${ }^{55}$.

Entre as posições jurídicas ativas situam-se, além dos poderes e das faculdades, os direitos. Não se procederá aqui a uma definição de direito, dada a enorme complexidade, senão impossibilidade, de alcançar um conceito único sobre o termo ${ }^{56}$. Para o presente estudo, importa ter em mente o significado de direito ligado à prova.

Nesse sentido, o direito à prova consistiria no direito das partes de empregar, durante a persecução penal, todos os meios e instrumentos de prova disponíveis a fim de demonstrar a veracidade dos fatos alegados.

Nas palavras de LUIGI PAOLO COMOGLIO, CORRADO FERRI e MICHELLE TARUFFO, "o direito à prova é o direito de influir no convencimento do juiz acerca dos fatos da causa, valendo-se das provas relativas a tais fatos ${ }^{, 57}$. Acrescentam os juristas que a garantia do direito à prova é fundamental para o exercício efetivo do direito de ação e do direito de defesa e que, por tal motivo, a possibilidade de demonstrar a

${ }^{55}$ Cf. GUSTAVO HENRIQUE IVAHY BADARÓ, Ônus da prova no processo penal, São Paulo, Revista dos Tribunais, 2003, pp. 168-169.

${ }^{56} \mathrm{Cf}$. TERCIO SAMPAIO FERRAZ JR., Introdução ao estudo do direito - Técnica, decisão, dominação, $4^{\mathrm{a}}$ ed., São Paulo, Atlas, 2003, p. 38.

${ }^{57}$ Cf. Lezioni sul processo civile, $2^{\mathrm{a}}$ ed., Bologna, Il Mulino, 1998, p. 609. Eis o aludido trecho, no idioma original: "il diritto alla prova è il diritto di influire sul convincimento del giudice intorno ai fatti della causa, servendosi delle prove relative a tali fatti". 
veracidade das alegações que formulam através das provas deve ser assegurada de modo pleno, e nos mais diferentes momentos do procedimento probatório ${ }^{58}$.

Definição parecida de direito à prova é trazida por MICHELLE TARUFFO. Para o autor, seria o direito da parte de empregar todas as provas de que dispõe, com o fim de demonstrar a verdade dos fatos que fundamentam sua pretensão ou resistência, assim como o direito de influir na formação do convencimento judicial acerca dos fatos versados na causa, através dos meios diretos e contrários de que se disponha ${ }^{59}$.

Necessário apenas ressaltar que o direito à prova está essencialmente ligado às garantias do contraditório, da ação e da defesa. Estes conceitos, aliás, convergem na constante possibilidade de participar ativamente do desenvolvimento do processo, sendo que o exercício concreto das aludidas garantias subordina-se à efetiva possibilidade de as partes servirem-se das provas para a formação do convencimento judicial ${ }^{60}$.

O jurista italiano MICHELLE TARUFFO chama ainda atenção para outro relevante aspecto do direito à prova, qual seja o de que as partes não dirigem sua atividade probatória necessariamente para a reconstrução completa e verídica da situação de fato em que se baseia a controvérsia. Afinal, nada garante que as alegações feitas pelas partes se baseiam em enunciados fáticos verdadeiros. Nas palavras do autor, "o fim que as partes tipicamente perseguem é o de ganhar o julgamento, servindo-se do direito à prova e realizando seu interesse em demonstrar o que tem o ônus de provar, mas este fim se persegue com independência da possibilidade de que a decisão se baseie em uma determinação verdadeira dos fatos. Trata-se de um lugar comum que, todavia, reflete adequadamente a realidade do que ocorre no processo ",61.

\footnotetext{
${ }^{58}$ Em artigo escrito exclusivamente por LUIGI PAOLO COMOGLIO, é trazida uma definição de direito à prova que alude justamente às fases do procedimento probatório. $\mathrm{O}$ direito à prova seria, pois, o "direito a obter do juiz a admissão, a aquisição e a assunção de qualquer prova admissível e relevante (ou, melhor dizendo, a admissão, a aquisição e a assunção de todas as provas que não sejam vedadas pela lei ou que não sejam manifestamente supérfluas e irrelevantes)". Cf. Prove ed accertamento dei fatti nel nuovo C.P.P. in Rivista Italiana di Diritto e Procedura Penale, ano 33, Milano, Giuffrè Editore, 1990, pp. 135-136. Eis o aludido conceito no idioma original: "diritto di ottenere dal giudice l'ammissione, l'acquisizione e l'assunzione di qualunque prova ammissibile e rilevante (o, per meglio dire, l'ammissione, l'acquisizione e l'assunzione di tutte le prove che non siano vietate dalla legge o che non siano manifestamente superflue ed irrelevanti)".

${ }^{59}$ Cf. Il diritto alla prova nel processo civile in Rivista di Diritto Processuale, Padova, CEDAM, n. 39, v. 77, janeiro-março de 1984, pp. 75-76 e 106.

${ }^{60}$ Cf. ADA PELLEGRINI GRINOVER, O conteúdo da garantia do contraditório in Novas tendências do direito processual, Rio de Janeiro, Forense Universitária, 1990, p.19.

${ }^{61}$ Cf. Simplesmente la verdad - El juez y la construcción de los hechos, trad. Daniela Accatino Scagliotti, Madrid, Marcial Pons, 2010, p. 194. O trecho foi traduzido livremente do seguinte: "el fin que las partes típicamente persiguen es el de ganar el juicio, sirviéndose del derecho a la prueba y realizando su interés en demonstrar lo que tienen la carga de probar, pero este fin se persigue com independencia de la posibilidad
} 
O reconhecimento de que uma ou ambas as partes de um processo podem não ter interesse na descoberta da verdade não afasta, porém, o reconhecimento de seu direito à prova, nem desqualifica os sistemas processuais que, mais do que a descoberta da verdade, objetivam a resolução dos conflitos.

Ainda sobre o assunto, observa MICHELLE TARUFFO que "as atuações das partes não podem ficar compreendidas no âmbito da dimensão epistemológica do processo. Inclusive se poderia dizer que se o processo está orientado epistemologicamente, isto é, se está dirigido à averiguação da verdade, isto ocorre não obstante as atuações defensivas desenvolvidas pelas partes”, que se encontram numa situação que poderia ser definida como de "implicação", contra-indicada para uma busca objetiva e desinteressada da verdade. O magistrado assume, nesse sentido, um papel fundamental na determinação da verdade dos fatos, sendo o sujeito a quem se atribui a tarefa de cuidar da admissibilidade das provas, zelar pela sua correta produção, e valorá-las adequadamente para a tomada de decisões ${ }^{62}$.

Pois bem, estabelecido o conceito de direito à prova e destacados alguns de seus aspectos mais relevantes, resta perquirir sobre sua natureza jurídica.

\subsubsection{Natureza jurídica}

Considerando, pois, que o direito à prova é um desdobramento tanto do exercício do contraditório como dos direitos de ação e de defesa ${ }^{63}$, natural que se atribua a ele a natureza jurídica de direito subjetivo: direito de participar de todas as fases do

de que la decisión se funde en una determinación verdadera de los hechos. Se trata de um lugar común que, sin embargo, refleja adecuadamente la realidad de lo que ocurre en el processo". Ao tratar da investigação realizada pela defesa, FRANCISCO DA COSTA OLIVEIRA expôs semelhante conclusão pois, segundo o jurista, "as investigações criminais levadas a cabo pelo próprio arguido deverão ser sempre preferencialmente dirigidas para a comprovação dos factos de que depende a sua Defesa e não à solução do crime, propriamente dita", afinal, a investigação particular não objetiva necessariamente a descoberta da verdade. Cf. A defesa e a investigação do crime, $2^{\mathrm{a}}$ ed. Coimbra, Almedina, 2008, p. 58.

${ }^{62}$ Cf. Simplesmente la verdad - El juez y la construcción de los hechos, trad. Daniela Accatino Scagliotti, Madrid, Marcial Pons, 2010, pp. 195-196. O trecho reproduzido também foi traduzido livremente do seguinte excerto: "las actuaciones de las partes no pueden quedar comprendidas en el ámbito de la dimensión epistémica del proceso. Incluso se podría decir que si el proceso está orientado epistémicamente, esto es, si está dirigido hacia la averiguación de la verdad, eso ocurre no obstante las actuaciones defensivas que desarrollan las partes".

${ }^{63}$ Cf. FLÁVIO LUIZ YARSHELL, Antecipação da prova sem o requisito da urgência e direito autônomo à prova, São Paulo, Malheiros, 2009, pp. 207-208. 
procedimento probatório e de ver introduzido no processo o material produzido por cada uma das partes, influenciando, dessa forma, o convencimento judicial ${ }^{64}$.

Ou seja, às partes é garantido, através do direito à prova, o direito de buscar elementos de informação aptos a demonstrar a veracidade das alegações formuladas, bem como o direito de ver tais dados objetivos inseridos no processo. Afinal, de nada ou muito pouco adiantaria assegurar às partes, principalmente à defesa, o direito de ser ouvido em juízo, formulando as próprias pretensões, se não lhes fosse permitido comprovar que as mesmas têm embasamento fático ${ }^{65}$.

Para FLÁVIO LUIZ YARSHELL, porém, mais que a um direito ou a um ônus, a idéia de prova se relaciona a um dever das partes, pois a descoberta da verdade não interessa apenas a estas, mas também ao Estado que presta a jurisdição, além do que constitui um instrumento eficaz para a edição de decisões justas e contribui, em alguma medida, para a segurança jurídica. Ou seja, para o autor, haveria um autêntico dever de provar, diretamente ligado a outros deveres, como os de colaboração, de lealdade, probidade, moralidade e de veracidade ${ }^{66}$.

No entanto, como já visto ${ }^{67}$, normalmente as partes de um processo, ou ao menos uma delas, não têm interesse em que a verdade venha à tona através do processo, pois isso significaria a obtenção de uma decisão judicial desfavorável. Como bem observa MICHELLE TARUFFO, "cada parte tem interesse em satisfazer a carga de prova que pesa sobre ela, mas isto não equivale em nenhum caso a dizer que as partes dirigem suas atividades processuais para a reconstrução completa e verídica da situação de fato em que se baseia a controvérsia. Na realidade, o que interessa às partes demonstrar é que as alegações de fato que constituem a premissa fática de suas demandas e exceções são fundadas. Nada garante, contudo, que as alegações realizadas pelas partes sejam formadas por enunciados fáticos verdadeiros $" 68$.

${ }^{64}$ Cf. ANTONIO MAGALHÃES GOMES FILHO, Direito à prova no processo penal, São Paulo, Revista dos Tribunais, 1997, p. 84.

${ }^{65}$ Cf. ANTONIO SCARANCE FERNANDES, Processo penal constitucional, $5^{\mathrm{a}}$ ed., São Paulo, Revista dos Tribunais, 2007, p. 78.

${ }^{66} \mathrm{Cf}$. Antecipação da prova sem o requisito da urgência e direito autônomo à prova, São Paulo, Malheiros, 2009, pp. 149-150.

${ }^{67}$ Item 1.3.2.

${ }^{68} \mathrm{O}$ trecho transcrito foi livremente traduzindo do seguinte: "cada parte tiene interés em satisfacer la carga de la prueba que pesa sobre ella, pero eso no equivale en ningún caso a decir que las partes dirigen sus actividades procesales hacia la reconstrucción completa e verídica de la situación de hecho em que se basa la controversia. En realidad, lo que a las partes les interesa demostrar es que las alegaciones de hecho que constituyen la premisa fáctica de sus demandas y excepciones son fundadas. Nada garantiza, sin embargo, 
Os sistemas processuais até podem estimular ou obrigar as partes a evitar condutas obstrutivas, tentando impedir o uso consciente de declarações ou provas falsas, mas isto certamente não equivale a impor às partes um dever de colaborar ativamente na determinação da verdade dos fatos. Segundo o jurista italiano, até o mais ardoroso defensor do princípio da colaboração duvida que a cooperação entre as partes e o juiz possa garantir a obtenção da verdade ${ }^{69}$.

Diante destas considerações, e da constatação de que a verdade absoluta é inatingível, existindo meramente verdades relativas tanto no processo como fora dele ${ }^{70}$, parece realmente mais acertado relacionar a atividade probatória a um direito das partes: direito de demonstrar a veracidade das alegações formuladas, e não dever de obtenção de uma verdade absoluta, que sequer existe.

$\mathrm{E}$, como o direito à prova possui a mesma natureza e o mesmo fundamento dos direitos e ação e de defesa, além de ser um direito subjetivo, é também um direito público ou cívico, já que tem como sujeito passivo o Estado, personificado na figura do magistrado, que tem o dever legal de efetivar os requerimentos das partes no que concerne à atividade probatória, desde que as postulações se apresentem legítimas ${ }^{71}$.

Verificada, assim, a natureza jurídica do direito à prova, imperioso destacar em tópico específico quem são os titulares de tal direito público subjetivo.

\subsubsection{Titularidade}

Diante das premissas estabelecidas anteriormente no sentido de que o direito à prova está intimamente ligado ao contraditório e aos direitos de ação e de defesa, natural supor que os titulares do direito à prova são os mesmos a quem o ordenamento

que las alegaciones realizadas por las partes estén formadas por enunciados fácticos verdaderos". Cf. Simplesmente la verdad - El juez y la construcción de los hechos, trad. Daniela Accatino Scagliotti, Madrid, Marcial Pons, 2010, pp. 194-195.

${ }^{69}$ Cf. Simplesmente la verdad - El juez y la construcción de los hechos, trad. Daniela Accatino Scagliotti, Madrid, Marcial Pons, 2010, p. 195.

${ }^{70}$ Cf. GUSTAVO HENRIQUE RIGHI IVAHY BADARÓ, Ônus da prova no processo penal, São Paulo, Revista dos Tribunais, 2003, pp. 36-37. Segundo o autor, "a verdade judicial, necessariamente relativa, deve ser entendida como uma "verdade" que o juiz busca nas provas existentes nos autos e que seja a "maior aproximação possível" daquilo que se denomina verdade, tout court".

${ }^{71}$ Cf. ANTONIO MAGALHÃES GOMES FILHO, Direito à prova no processo penal, São Paulo, Revista dos Tribunais, 1997, pp. 84-85. 
jurídico reconhece aqueles outros direitos na ação penal condenatória ${ }^{72}$, ou seja, ao acusador e ao réu ${ }^{73}$.

Logo, tanto ao titular da ação penal (Ministério Público ou querelante) como ao acusado é assegurado o direito de utilizar, ao longo da persecução penal, os meios e instrumentos necessários à comprovação de suas asserções, o que implica, na fase processual, a possibilidade de influenciar positivamente a formação da convicção do juiz sobre o fato imputado e demais circunstâncias relevantes à causa penal.

Neste ponto, algumas importantes observações devem ser feitas. Embora as alegações feitas sobre o fato criminoso constituam o cerne da atividade probatória, não constituem seu único objeto. O Código de Processo Penal italiano, por exemplo, assevera em seu art. 187 que são objeto da prova os fatos que se referem à imputação, à punibilidade e à determinação da pena ou da medida de segurança. Os parágrafos do aludido dispositivo acrescentam ao objeto da prova os fatos dos quais depende a aplicação de normas processuais e os fatos inerentes à responsabilidade civil decorrente do crime, caso tenha havido a constituição de parte civil $^{74}$.

Ou seja, são objeto da prova não só os fatos relativos à conduta típica da norma incriminadora, mas também aqueles pertinentes e úteis para a verificação das alegações formuladas pelas partes acerca das demais circunstâncias que envolvem o delito $^{75}$.

Ao tratar do objeto da prova, observam MARIO PISANI, ALFREDO MOLARI, VINCENZO PERCHINUNNO e PIERMARIA CORSO que são três os "perfís" que a investigação probatória deve levar em consideração: perfil objetivo, que consiste na verificação da ocorrência do fato histórico transformado em imputação e sua qualificação jurídica, perfil subjetivo, que diz respeito à individualização da responsabilidade do sujeito

${ }^{72}$ Neste ponto, não é demasiado recordar que, embora se possa falar em tutela meramente declaratória (ex: habeas corpus preventivo), constitutiva (ex: revisão criminal), executiva e também cautelar no âmbito processual penal, a forma de tutela jurisdicional mais comum é a condenatória. Cf. GUSTAVO HENRIQUE RIGHI IVAHY BADARÓ, Direito processual penal, Tomo I, Rio de Janeiro, Elsevier, 2008, pp. 74-76. Por este motivo, a referência ao direito à prova e seus corolários será feita, no mais das vezes, com base na ação penal condenatória. Reconhece-se, porém, a existência do mesmo direito, ainda que com diferentes nuances, nas demais espécies de tutela jurisdicional.

${ }^{73}$ Cf. ANTONIO MAGALHÃES GOMES FILHO, Direito à prova no processo penal, São Paulo, Revista dos Tribunais, 1997, p. 84.

${ }^{74}$ Eis o referido dispositivo legal, em vernáculo: "1. Sono oggeto di prova i fatti che si riferiscono all'imputazione, alla punibilità e alla determinazione della pena o della misura di sicurezza. 2. Sono altresì oggeto di prova i fatti dai quali dipende l'applicazione di norme processuali. 3. Se vi è costituzione di parte civile, sono inoltre oggeto di prova i fatti inerenti alla responsabilità civile derivante dal reato".

${ }^{75}$ Cf. GIUSTINO GATTI, Codice di procedura penale annotato com la giurisprudenza, $18^{\mathrm{a}}$ ed., Napoli, Grupo Editoriale Esselibri Simone, 2010, p. 493. 
e sua imputabilidade, e quantitativo, este relativo à medida da pena e à aplicação de medida de segurança. Os autores trazem ainda como exemplo de fato do qual depende a aplicação de norma processual (e que consiste em objeto de prova, nos termos do art. 187 do CPP italiano) a ocorrência de caso fortuito ou de força maior, que impediu a observância de prazo peremptório. A comprovação do aludido fato permitiria a devolução do prazo perdido ${ }^{76}$.

Embora a legislação processual penal brasileira não conte com previsão semelhante ao art. 187 do Código de Processo penal italiano, também entre nós o objeto da prova é amplo, não se resumindo unicamente às alegações relativas à conduta típica prevista na norma incriminadora. Observa MARCELLUS POLASTRI LIMA que "não somente o fato criminoso praticado e a autoria do mesmo devem ser objeto de pesquisa através da prova, mas também as circunstâncias subjetivas e objetivas que circundam o fato praticado, ou tudo que seja importante para a descoberta da verdade provável e apuração da responsabilidade do agente, visando à aplicação da pena ou medida de segurança, excluídas as questões não relevantes para o deslinde da lide ",77.

Lembra ainda GUSTAVO HENRIQUE RIGHI IVAHY BADARÓ que não constituem objeto de prova apenas os fatos impertinentes, irrelevantes e notórios; até os fatos incontroversos devem ser provados no âmbito processual penal, já que a mera confisssão do réu não induz à sua condenação. E, por aplicação analógica do art. 137 do Código de Processo Civil pátrio, se o juiz determinar, à parte cabe provar o teor e a vigência do direito municipal, estadual, estrangeiro e consuetudinário ${ }^{78}$. Em outras palavras, o objeto do direito à prova não se limita às alegações feitas sobre o fato imputado, é mais vasto, envolve questões subjetivas, dados sobre a culpabilidade e a punibilidade, entre outros.

Considerando, assim, a amplitude do objeto da prova no processo penal, caberia perquirir se os titulares do direito à prova são apenas o acusador e a defesa.

A propósito, nos tratados internacionais de direitos humanos, assim como na legislação brasileira, nota-se uma clara preocupação em assegurar à defesa as prerrogativas inerentes ao direito à prova, o que não significa que à acusação não sejam conferidos poderes de participação em todas as fases do procedimento probatório, como

\footnotetext{
${ }^{76}$ Cf. Manuale di procedura penale, Bologna, Monduzzi, 1994, p. 226.

${ }^{77} \mathrm{Cf}$. A prova penal de acordo com a reforma processual penal, $3^{\mathrm{a}}$ ed., Rio de Janeiro, Lumen Juris, 2009, p. 25.

${ }^{78}$ Cf. Direito processual penal, Tomo I, Rio de Janeiro, Elsevier, 2008, p. 204.
} 
bem ressaltou ANTONIO MAGALHÃES GOMES FILHO ${ }^{79}$. Na verdade, arrisca-se aqui afirmar que o cuidado em estabelecer expressamente certas garantias à defesa se deve ao fato de que, via de regra, é ao acusado que na prática são negados direitos e prerrogativas previstos em lei, não à acusação ${ }^{80}$.

Daí a necessidade de salientar nos textos legais os direitos e garantias que devem ser sempre assegurados à defesa, não se podendo olvidar que esta é garantida pelo contraditório, mas também o garante, na exata medida em que representa um aspecto integrante do próprio direito de ação ${ }^{81}$.

Pois bem, se não há dúvidas de que o direito à prova é assegurado ao Ministério Público e ao querelante, respectivamente, titulares da ação penal pública e privada, assim como ao acusado, maiores dúvidas cercam a possibilidade de estender o direito à prova a outros sujeitos processuais, ou a outras partes.

Neste ponto, mostra-se oportuno realizar uma pequena digressão acerca das noções de sujeitos processuais e partes, das diferenças existentes entre elas e de sua relação com o direito à prova.

Para JULIO B. J. MAIER, o conceito de "sujeito processual” é prescindível, carece de valor sistemático, representa mero problema terminológico, semântico. Para o autor, mais importante que definir ou classificar os sujeitos processuais é enumerá-los. Isto porque, para conceituar sujeitos processuais (partícipes ou intervenientes), não bastaria a idéia de exercício independente ou autônomo das faculdades processuais ou dos deveres impostos pelas regras, tal como comumente sustenta a doutrina: por tal critério, a testemunha, o perito e até a polícia seriam sujeitos processuais ${ }^{82}$.

De acordo com o jurista argentino, existem na verdade certos fatores que permitem incluir ou excluir certas pessoas da categoria "sujeitos processuais penais", quais sejam a assunção ou não de papéis centrais no procedimento, o exercício ou não de funções imprescindíveis, a defesa de interesses próprios ou alheios. A propósito, por tais critérios os chamados "sujeitos processuais penais" comportam diferentes classificações, entre as

${ }^{79}$ Cf. Direito à prova no processo penal, São Paulo, Revista dos Tribunais, 1997, p. 84.

${ }^{80}$ Sobre a estreita ligação entre direito à prova e ampla defesa, veja-se JACINTO NELSON DE MIRANDA COUTINHO, Ampla defesa e direito à contraprova in Revista Brasileira de Ciências Criminais, $\mathrm{n}^{0}$ 55, vol. 13, 2005, pp. 364-386.

81 Cf. ADA PELLEGRINI GRINOVER, ANTONIO SCARANCE FERNANDES e ANTONIO MAGALHÃES GOMES FILHO, As nulidades no processo penal, $11^{\mathrm{a}}$ ed., São Paulo, Revista dos Tribunais, 2009, p. 69.

${ }^{82}$ Cf. Derecho procesal penal, Tomo II, Parte General - Sujetos procesales, Buenos Aires, Editores del Puerto, 2003, pp. 40-41. 
quais protagonistas estatais (tribunal, Ministério Público e polícia) e protagonistas privados (imputado, defensor, querelante adesivo/conjunto ou exclusivo, autor civil), sujeitos essenciais (tribunal, acusador (Ministério Público e/ou querelante), imputado, defensor) e sujeitos eventuais (querelante adesivo/conjunto, autor civil, imputado como demandado civil e terceiro civilmente demandado $)^{83}$, entre outros.

Para outra parcela da doutrina, os conceitos de sujeitos processuais e partes apresentam maior relevância. O jurista português JORGE DE FIGUEIREDO DIAS define sujeitos processuais como os "participantes a quem competem direitos e deveres processuais autônomos, no sentido de que, através de suas próprias decisões, podem codeterminar, dentro de certos limites, a concreta tramitação do processo", sendo que à idéia de "participantes processuais" correspondem "todas as pessoas e entidades que, investidas nas mais diversas funções, actuam juridicamente no processo e para as quais, por isso, nascem daquele diferentes direitos e obrigações". Nesse sentido, seriam sujeitos processuais o tribunal, o Ministério Público e outros titulares da acusação, o arguido e seu defensor, o ofendido e o assistente. Por outro lado, seriam meros participantes processuais as testemunhas, os declarantes, os peritos, os intérpretes, entre outros ${ }^{84}$.

Já as partes poderiam ser definidas tanto em seu aspecto material como em seu aspecto formal, segundo o jurista lusitano. Pelo conceito substantivo de partes, estas seriam os "titulares da relação jurídica substantiva que no processo se discute", ao passo que, pelo conceito processual de partes, estas corresponderiam aos "sujeitos processuais que discutem a causa e esperam do juiz uma apreciação e decisão do mérito dela" $\$ 5$.

Para PAOLO TONINI, sujeitos são os titulares de poderes de iniciativa no procedimento. Observa o autor que o CPP italiano não define sujeitos processuais, mas foi bastante generoso ao elencá-los: juiz, Ministério Público, polícia judiciária, imputado, parte civil, responsável civil, civilmente obrigado pela pena pecuniária, pessoa ofendida e defensor. As testemunhas e os peritos, por exemplo, não são sujeitos processuais, inseremse na categoria de "pessoas" que participam do procedimento. Ressalta ainda o autor que os sujeitos vêm definidos em relação à noção de procedimento penal, que abrange também

${ }^{83}$ Cf. Derecho procesal penal, Tomo II, Parte General - Sujetos procesales, Buenos Aires, Editores del Puerto, 2003, pp. 41-52.

${ }^{84}$ Cf. Direito processual penal, Coimbra, Coimbra Editora, 2004, pp. 240-241.

${ }^{85}$ Cf. Direito processual penal, Coimbra, Coimbra Editora, 2004, pp. 242-244. Acrescenta ainda o autor às pp. 245-246 que, para responder à pergunta se determinado processo penal constitui ou não um processo de partes, estas devem ser tomadas em sua acepção processual material, ou seja, como os "titulares de interesses contrapostos que no processo se discutem e se encontram concretamente em jogo". 
a fase investigatória. Ou seja, mesmo antes de proposta a ação penal, já seria possível falar em sujeitos ${ }^{86}$.

Já o conceito de partes estaria fortemente atrelado à idéia de ação, segundo o jurista italiano. Seriam, assim, partes, o sujeito ativo e o sujeito passivo da ação penal, ou seja, aquele que pediu ao juiz uma decisão relativa à imputação e aquele contra o qual a decisão foi requerida. Segundo o autor, são partes necessárias o Ministério Público e o imputado, e partes eventuais o civilmente obrigado pela pena pecuniária (figura que, no direito italiano, equivale à pessoa a quem incumbe o pagamento da pena pecuniária em caso de insolvência do imputado), o lesado pelo crime que tenha se constituído parte civil contra o imputado, e o responsável civil por ventura acionado pela parte civil ${ }^{87}$.

Considerando que o direito à prova está intimamente ligado aos direitos de ação e de defesa, que o objeto da prova é amplo, pois abrange não apenas as alegações sobre o fato criminoso, mas também demais circunstâncias relevantes à causa penal, entre as quais questões subjetivas, dados sobre a culpabilidade e sobre a pena, e que o conceito de partes é mais restrito que o de sujeitos processuais, pois exclui aqueles que participam do processo sem deduzir ou ver deduzida contra si qualquer pretensão ${ }^{88}$, é possível afirmar que são titulares do direito à prova as partes, necessárias ou eventuais. Ou seja, por tal critério, não apenas o Ministério Público/querelante, e o acusado (partes essenciais) são titulares do direito à prova, mas também o assistente de acusação, caso se faça presente na ação penal. Todos estes têm direito a produzir provas necessárias à comprovação de suas aduções.

No Código de Processo Penal brasileiro, não há referência nem sistematização das categorias sujeitos e partes processuais; aqueles que participam do processo foram apenas nominados e disciplinados no Livro I, Título VIII, do diploma. Em nosso sistema, sequer há previsão de partes eventuais como as verificadas no ordenamento argentino ou italiano (parte civil, responsável civil, entre outros), talvez porque, embora a

${ }^{86}$ Cf. Manuale breve - Diritto processuale penale, Milano, Giuffrè, 2009, pp.39-40.

${ }^{87}$ Cf. Manuale breve - Diritto processuale penale, Milano, Giuffrè, 2009, p. 40.

${ }^{88}$ Embora não se ignore a existência de autores que sustentam a inexistência de partes propriamente ditas no processo penal (conforme bem recorda FERNANDO DA COSTA TOURINHO FILHO, Processo Penal, $31^{\mathrm{a}}$ ed., vol. 2, São Paulo, Saraiva, 2009, p. 467), e se reconheça a dificuldade alcançar um conceito unívoco de partes, questão que, por sua complexidade, poderia constituir objeto de trabalho específico, optou-se, neste estudo, pela adoção de uma definição tradicional e bastante simples, segundo a qual partes são aquelas pessoas que pedem e contra as quais se pede a tutela jurisdicional. Cf. JOSÉ FREDERICO MARQUES, Elementos de direito processual penal, vol. II, $3^{\mathrm{a}}$ ed., Campinas, Millenium, 2009, p. 16. 
cumulação da ação civil com a ação penal seja a regra em vários países europeus, como Alemanha, França, Itália e Portugal, não é, em geral, admitida, no Brasil ${ }^{89}$.

Dessa forma, a única parte eventual prevista expressamente em nosso sistema processual penal é o assistente de acusação. Segundo FERNANDO DA COSTA TOURINHO FILHO, o assistente de acusação é uma parte contingente pois, embora a lei permita sua intervenção no processo, este existirá com ou sem ele ${ }^{90}$. Nas palavras de GUSTAVO HENRIQUE RIGHI IVAHY BADARÓ, trata-se de uma parte “ad coadjuvandum”, que auxilia o Ministério Público na ação penal pública ${ }^{91}$.

Vale lembrar que é o ofendido/vítima do delito que tem legitimidade para intervir como assistente de acusação ${ }^{92}$, entendendo-se por ofendido o titular do interesse jurídico protegido, ainda que de modo não prevalente, pela norma incriminadora que se reputa violada pelo crime ${ }^{93}$. O referido conceito, aliás, se coaduna com o entendimento crescente da doutrina no sentido de admitir a atuação do ofendido como assistente da acusação nos crimes em que o sujeito passivo primário é o Estado ${ }^{94}$.

Lembra JOSÉ FREDERICO MARQUES que, intervindo o ofendido como assistente de acusação, passa a ter os direitos processuais subjetivos de parte no processo ${ }^{95}$, entre os quais o de produzir provas. Vale ressaltar que, usualmente, se discute a natureza do interesse do assistente de acusação, se meramente patrimonial (o que, no fim,

${ }^{89}$ Cf. ANTONIO SCARANCE FERNANDES, Processo penal constitucional, $6^{\mathrm{a}}$ ed., São Paulo, Revista dos Tribunais, 2010, p. 177. Ressalva, no entanto, o autor que tem havido uma crescente aproximação entre os juízos civil e penal no direito brasileiro, a exemplo da possibilidade de composição civil dos danos no âmbito da Lei 9.099/95, e da possibilidade de as varas criminais cumularem competência civil e criminal em matéria de violência doméstica, enquanto não estruturados os Juizados de Violência Doméstica e Familiar contra a Mulher.

${ }^{90}$ Cf. Processo Penal, $31^{\text {a }}$ ed., vol. 2, São Paulo, Saraiva, 2009, p. 533.

${ }^{91}$ Cf. Direito processual penal, Tomo I, Rio de Janeiro, Elsevier, 2008, p. 158. É válido mencionar que, já na década de 90, FÁTIMA ZIYADE identificava quatro principais correntes que buscavam explicar a natureza jurídica de tal figura (parte civil, auxiliar da acusação, substituto processual e parte adesiva). Filiando-se ao posicionamento segundo o qual o assistente de acusação é efetivamente uma parte, que atua em litisconsórcio ativo com o Parquet, asseverou a autora que "a assistência constitui uma espécie de intervenção de terceiros no processo na modalidade voluntária. Ao intervir, o assistente tem movimentos independentes em relação ao Ministério Público, e sua intervenção adesiva o coloca na posição de parte, como litisconsorte do parquet”. Cf. O assistente da acusação, Porto Alegre, Livraria do Advogado, 1993, p. 27.

${ }_{92}$ O Código de Processo Penal brasileiro prevê em seu art. 268 que poderá atuar como assistente do Ministério Público o ofendido ou seu representante legal, ou, na falta, qualquer das pessoas mencionadas no art. 31 (cônjuge, ascendente, descendente ou irmão).

${ }_{93}$ Cf. PAOLO TONINI, Manuale breve - Diritto processuale penale, Milano, Giuffrè, 2009, p. 99.

94 Cf. GUSTAVO HENRIQUE RIGHI IVAHY BADARÓ, Direito processual penal, Tomo I, Rio de Janeiro, Elsevier, 2008, p. 161. O autor traz ainda exemplos de situações especiais em que pessoas ou entidades que, a rigor, não são ofendidos propriamente ditos, podem atuar no processo penal como assistentes (pp. 162-163). No mesmo sentido, veja-se GUILHERME DE SOUZA NUCCI, Código de processo penal comentado, $8^{\mathrm{a}}$ ed., São Paulo, Revista dos Tribunais, 2008, pp. 567-568.

${ }^{95} \mathrm{Cf}$. Elementos de direito processual penal, vol. II, $3^{\mathrm{a}}$ ed., Campinas, Millenium, 2009, p. 61. 
restringiria os limites da atividade probatória, pois a vítima só buscaria obter o título executivo necessário à satisfação de sua pretensão no âmbito civil) ou mais amplo, ancorado na correta aplicação da lei penal, o que alargaria o espectro de sua atuação probatória e possibilitaria ao assistente recorrer da sentença meramente para aumentar a pena.

Respeitadas as opiniões em contrário $^{96}$, parece mais acertado o entendimento professado inclusive pelo Supremo Tribunal Federal ${ }^{97}$, segundo o qual o interesse da vítima ao ingressar num processo como assistente de acusação não é meramente econômico, sua atuação visa ao auxílio do Ministério Público no exercício da tese acusatória amplamente considerada.

Este, aliás, era o posicionamento de FÁTIMA ZIYADE, que, ao debruçarse sobre a figura do assistente de acusação, asseverou que sua atuação nos crimes em que não há dano não se justificaria se o seu interesse fosse exclusivamente econômico. Concluiu a autora que o assistente visa também à correta aplicação da sanção penal ao agente infrator ${ }^{98}$.

No mesmo sentido, sustenta GUSTAVO HENRIQUE RIGHI IVAHY BADARÓ que, "se o interesse do assistente da acusação fosse apenas patrimonial, visando a obter uma reparação do dano, não seria admissível assistência em crime tentado ou crime de que não resultasse prejuízo material. Mais do que isso, caso a demanda cível já tivesse sido proposta e o ofendido já tivesse obtido a condenação cível transitada em julgado, a assistência não deveria ser admitida. Tais situações, contudo, não se verificam na prática",99.

Na maioria dos países de Civil Law, a intervenção do ofendido no processo penal é bastante restrita, limitando-se, no mais das vezes, à função de parte civil. Em Portugal, porém, existe a figura do assistente de acusação, que, disciplinada de modo muito semelhante ao verificado em nosso ordenamento, embora com algumas peculiaridades,

\footnotetext{
${ }^{96}$ Por exemplo, FERNANDO DA COSTA TOURINHO FILHO, Processo Penal, $31^{\text {a }}$ ed., vol. 2, São Paulo, Saraiva, 2009, p. 538.

${ }^{97}$ Sobre o assunto, já na década de 90 decidiu a E. Corte que o interesse do ofendido "não está limitado à reparação civil do dano, mas alcança a exata aplicação da justiça penal” (HC 71453/GO, Segunda Turma, Relator Min. Paulo Brossard, j. 06/09/1994), entendimento este que, ademais, vai ao encontro do proferido pelo STF em outras decisões que admitiram a interposição de recurso pelo assistente de acusação apenas para fins de majoração da pena (ex: HC 83582/RJ, Segunda Turma, Relator Min. Gilmar Mendes, j. 10/04/2007, HC 66754/RJ, Primeira Turma, Relator Min. Octavio Gallotti, j. 18/11/1988).

${ }^{98}$ Cf. O assistente da acusação, Porto Alegre, Livraria do Advogado, 1993, p. 29.

${ }^{99}$ Cf. Direito processual penal, Tomo I, Rio de Janeiro, Elsevier, 2008, p. 159.
} 
também apresenta diversos poderes, entre os quais o de participar da atividade probatória $^{100}$.

Em Portugal, aliás, o assistente de acusação pode intervir já na instrução preparatória, ainda que no papel de colaborador subordinado ao Ministério Público. Neste sentido, pode apresentar ao Parquet memoriais ou requerimento de diligências probatórias, as quais poderão ou não ser realizadas, dependendo do entendimento do Ministério Público sobre a relevância das medidas para a demonstração dos fatos. $\mathrm{Na}$ instrução dita contraditória, o assistente pode intervir diretamente, assistindo aos atos probatórios, requerendo ao juiz a formulação de perguntas às testemunhas ou esclarecimentos ao perito, entre outros ${ }^{101}$.

Nesse diapasão, o Código de Processo Penal brasileiro atribui ao assistente de acusação prerrogativas bem mais restritas. De início, vale recordar que, nos termos do art. 268 do diploma, o ofendido não pode intervir na fase investigatória, mas apenas depois de proposta a ação penal, e até o trânsito em julgado da condenação, conforme o art. 269 do mesmo texto legal ${ }^{102}$.

E, consoante o disposto no art. 271 do diploma em comento, o assistente de acusação pode propor meios de provas e requerer perguntas às testemunhas, previsão esta que poderia levar à conclusão de que a tal parte não é facultado requerer a produção de prova testemunhal, tal como the é permitido em relação a outros meios de prova, mas apenas formular perguntas às testemunhas arroladas pelas outras partes ${ }^{103}$. Tal entendimento, porém, não tem prevalecido, na doutrina ${ }^{104}$ e na jurisprudência, havendo vários julgados do Supremo Tribunal Federal a reconhecer a possibilidade de o assistente de acusação arrolar testemunhas ${ }^{105}$.

${ }^{100}$ Cf. JORGE DE FIGUEIREDO DIAS, Direito processual penal, Coimbra, Coimbra Editora, 2004, pp. 508-520.

${ }^{101}$ Cf. JORGE DE FIGUEIREDO DIAS, Direito processual penal, Coimbra, Coimbra Editora, 2004, p. 522.

102 Dispõe o art. 269 do CCP pátrio que "o assistente será admitido enquanto não passar em julgado a sentença e receberá a causa no estado em que se encontrar”. A regra, interpretada conjuntamente com a previsão do art. 268 do mesmo diploma, já referido, apresenta relevância para a aferição do direito à investigação do ofendido na fase inicial da persecução penal, como se verá adiante.

${ }^{103}$ Esta é a posição de GUSTAVO HENRIQUE RIGHI IVAHY BADARÓ, pois o momento para a acusação arrolar testemunhas é o do oferecimento da denúncia, e quando do ingresso do assistente no feito, tal ato já terá ocorrido. Cf. Direito processual penal, Tomo I, Rio de Janeiro, Elsevier, 2008, p. 164.

${ }^{104}$ Por exemplo, GUILHERME DE SOUZA NUCCI, Código de processo penal comentado, $8^{\mathrm{a}}$ ed., São Paulo, Revista dos Tribunais, 2008, p. 569.

${ }^{105}$ Cf. HC 73390/RS, Segunda Turma, Relator Min. Carlos Velloso, j. 12/03/1996, HC 72.484/GO, Primeira Turma, Relator Min. Ilmar Galvão, j. 31/10/1995. 
Seja como for, importa ressaltar que também o assistente de acusação, na qualidade de parte eventual, é titular do direito à prova, ainda que de maneira não tão ampla quanto as partes necessárias na ação penal condenatória. Em outras palavras, não apenas o Ministério Público e o réu são titulares do direito em comento, mas também a vítima, quer quando atua na condição de querelante, quer quando atua na condição de assistente de acusação.

Vistos, pois, o conceito, a natureza jurídica e a titularidade do direito à prova, resta finalmente analisar o seu conteúdo, de extrema relevância ao objeto deste estudo.

\subsubsection{Conteúdo}

Normalmente, o conteúdo do direito à prova é apresentado como correspondente às fases do procedimento probatório ${ }^{106}$, o que é até compreensível, pois, em cada uma das etapas do aludido procedimento, direitos e prerrogativas diferentes são asseguradas às partes. ADA PELLEGRINI GRINOVER, por exemplo, afirma categoricamente que o direito à prova no processo penal abrange todas as fases do procedimento probatório $^{107}$.

Normalmente, enumeram-se apenas quatro momentos relacionados à atividade probatória, quais sejam proposição, admissão, produção e valoração ${ }^{108}$. A primeira etapa corresponderia à fase de indicação ou requerimento pelas partes das provas que desejam ver produzidas, já a segunda consistiria no momento em que o magistrado se manifesta sobre a admissibilidade dos meios de prova propostos, a terceira, por seu turno, diria respeito à efetiva introdução das provas no processo, e a última etapa, finalmente, se relacionaria à apreciação, pelo juiz, das provas produzidas ${ }^{109}$.

O conteúdo do direito à prova estaria relacionado, pois, a estas fases do procedimento probatório.

${ }^{106}$ Cf. GUILHERME MADEIRA DEZEM, Da prova penal: tipo processual, provas típicas e atípicas, Campinas, Millenium, 2008, p. 89.

${ }^{107}$ Cf. A marcha do processo, Rio de Janeiro, Forense Universitária, 2000, p. 452.

108 Esta divisão do procedimento probatório é trazida, entre outros autores, por PAULO RANGEL. Cf. Direito processual penal, $10^{\mathrm{a}}$ ed., Rio de Janeiro, Lumen Juris, 2005, p. 456.

109 Cf. ADA PELLEGRINI GRINOVER, ANTONIO SCARANCE FERNANDES e ANTONIO MAGALHÃES GOMES FILHO, As nulidades no processo penal, $11^{\mathrm{a}}$ ed., São Paulo, Revista dos Tribunais, 2009, p. 113. 
Numa visão mais abrangente da matéria, sustenta ANTONIO SCARANCE FERNANDES que o direito à prova compreende os seguintes direitos: de requerer a produção da prova, de que o juiz decida sobre tal pedido, de que a prova deferida seja realizada, de que sua produção observe o contraditório e se dê na presença do juiz, de que as partes possam se manifestar sobre a prova produzida, e de que a prova seja avaliada pelo julgador $^{10}$.

Conteúdo semelhante ao acima proposto é trazido por LUIGI PAOLO COMOGLIO, CORRADO FERRI e MICHELLE TARUFFO. Segundo os juristas, o direito à prova compreende o direito de deduzir provas que servem à comprovação das próprias afirmações, o direito à prova contrária (que seria o direito a servir-se de todas as provas necessárias a demonstrar o contrário daquilo que a outra parte pretende demonstrar), assim como o direito à admissão da prova e à sua valoração ${ }^{111}$.

Há, no entanto, juristas que entendem que o procedimento probatório não se limita às fases de proposição, admissão, produção e valoração das provas. Para GUSTAVO HENRIQUE IVAHY BADARÓ, por exemplo, há ainda outro momento probatório, anterior a todos os mencionados, que seria o relativo à investigação criminal ${ }^{112}$.

Admitindo-se, pois, que a etapa inicial da persecução penal, correspondente à fase de investigação, também consiste numa fase do procedimento probatório, natural que o direito à investigação seja considerado como um dos desdobramentos do direito à prova.

$\mathrm{Na}$ doutrina brasileira, referido posicionamento é defendido há bastante tempo por ANTONIO MAGALHÃES GOMES FILHO, para quem o direito à prova deve "permear o fenômeno probatório em sua integralidade, ou seja, deve ser possível em todas aquelas tarefas de procura e colheita dos dados que permitirão ao juiz verificar a ocorrência, ou não, dos acontecimentos históricos afirmados pelas partes e sobre os quais irá versar a sentença final ${ }^{\text {,113. }}$.

No mesmo sentido, sustenta PAOLO TONINI que o direito à prova compreende, em primeiro lugar, o direito de todas as partes de buscar as fontes de prova (que seria o direito à investigação), além das prerrogativas de requerer a admissão do

\footnotetext{
${ }^{110}$ Cf. Processo penal constitucional, $5^{\mathrm{a}}$ ed., São Paulo, Revista dos Tribunais, 2007, pp. 79-80.

${ }^{111}$ Cf. Lezioni sul processo civile, $2^{\mathrm{a}}$ ed., Bologna, Il Mulino, 1998, pp. 609-610.

${ }^{112}$ Cf. Direito processual penal, Tomo I, Rio de Janeiro, Elsevier, 2008, p. 204.

${ }^{113}$ Cf. Direito à prova no processo penal, São Paulo, Revista dos Tribunais, 1997, p. 84.
} 
respectivo meio de prova, participar de sua produção e apresentar uma valoração no momento das conclusões ${ }^{114}$.

Digno de nota, ainda, o entendimento do jurista brasileiro FLÁVIO LUIZ YARSHELL, para quem o direito à prova consistiria basicamente no direito à investigação. Segundo o autor, as expressões são equivalentes, já que o direito à prova consiste no “direito à busca, à obtenção e à pré-constituição daquela”. É que, na verdade, o autor diferencia o "direito à prova" do "direito de provar", este sim abrangendo o requerimento, a admissão, a produção e a valoração da prova em juízo. Para o autor, o chamado "direito de provar" consistiria no direito de "empregar todos os meios disponíveis para demonstração da verdade dos fatos em que fundada uma pretensão ou resistência, no contexto de um dado processo cujo objeto é a declaração do direito "115.

Não obstante a plausibilidade da distinção levada a efeito por FLÁVIO LUIZ YARSHELL, neste trabalho opta-se pelo uso da expressão direito à prova no sentido mais usual e abrangente do termo, englobando todas as fases do procedimento probatório, inclusive a extraprocessual, além das processuais propriamente ditas.

Estabelecido, pois, que, para os fins deste trabalho, a expressão direito à prova abrange tanto os direitos à proposição, admissão, produção e valoração da prova, como o direito à investigação, é chegado o momento de analisar o último dos referidos direitos em si. Por constituir o tema central deste estudo, merece o direito à investigação ser objeto de análise em capítulo específico.

${ }^{114}$ Cf. A prova no processo penal italiano, trad. Alexandra Martins e Daniela Mróz, São Paulo, Revista dos Tribunais, 2002, p. 83.

${ }^{115}$ Cf. Antecipação da prova sem o requisito da urgência e direito autônomo à prova, São Paulo, Malheiros, 2009, pp. 232-233. 


\section{CAPÍTULO II - DIREITO À INVESTIGAÇÃo}

\subsection{CONCEITO E FUNDAMENTO}

Como já adiantado no capítulo anterior, o direito à investigação consiste em um dos desdobramentos do direito à prova. Uma vez que o conteúdo deste se liga diretamente às fases do procedimento probatório e às prerrogativas a serem exercidas em cada uma dessas etapas, o direito à investigação, que seria o direito a buscar as fontes de prova $^{116}$, seria o primeiro a poder ser exercido pelas partes.

O direito à prova compreende, assim, tanto a prerrogativa de buscar as provas e a elas ter acesso, como os direitos de requerê-las, de vê-las admitidas, de participar de sua produção e de obter sua valoração, nessa ordem ${ }^{117}$.

Oportuno salientar que o entendimento acima esposado não é pacífico na doutrina nacional ou estrangeira. Inexiste consenso sobre quais seriam as fases do procedimento probatório, havendo autores que apontam apenas duas, três, ou então quatro etapas da atividade probatória, sem sequer mencionar o momento de pesquisa do material de prova, vez que anterior ao processo ${ }^{118}$.

Para os juristas italianos GIOVANNI CONSO e VITTORIO GREVI, por exemplo, o direito à prova se desdobraria basicamente em outros dois direitos, quais sejam os de requerer a admissão da prova e de obter a prova requerida ${ }^{119}$. Já para DELFINO SIRACUSANO, o direito à prova englobaria os direitos à admissão do meio de prova, o direito ao próprio meio de prova, ou seja, à potencial representação que este permite, e o direito à correta elaboração probatória ${ }^{120}$.

Parece mais acertado, todavia, o posicionamento segundo o qual não apenas os aspectos endo-processuais devem ser levados em consideração no que concerne ao procedimento probatório, pois as fontes de prova são conhecidas antes mesmo de ter início

${ }^{116}$ Cf. GUSTAVO HENRIQUE IVAHY BADARÓ, Direito processual penal, Tomo I, Rio de Janeiro, Elsevier, 2008, p. 204.

${ }^{117}$ Cf. FLÁVIO LUIZ YARSHELL, Antecipação da prova sem o requisito da urgência e direito autônomo à prova, São Paulo, Malheiros, 2009, p. 210.

${ }^{118}$ O jurista VICENTE GRECO FILHO entende que são apenas três os momentos da prova, quais sejam o do requerimento ou propositura, o do deferimento e o da produção. Cf. Manual de processo penal, $7^{\underline{a}}$ ed., São Paulo, Saraiva, 2009, p. 196. Já o autor PAULO RANGEL alude a quatro fases do procedimento probatório (proposição, admissão, produção e valoração). Cf. Direito processual penal, $10^{a}$ ed., Rio de Janeiro, Lumen Juris, 2005, 456.

${ }^{119}$ Cf. Compendio di procedura penale: appendice di aggiornamento, Padova, CEDAM, 2001, pp. 290-291.

${ }^{120}$ Cf. Manuale di diritto processuale penale, vol. 1, Milano, Giuffrè, 1990, p. 395. 
o processo, além do que é possível, em certas hipóteses, que provas sejam efetivamente produzidas antes de proposta a ação penal. Por tal razão é que o direito à prova deve ser reconhecido antes ou fora do processo.

Na lição de ANTONIO MAGALHÃES GOMES FILHO, é possível falar-se num autêntico direito à investigação, pois "a faculdade de procurar e descobrir provas é condição indispensável para que se possa exercer o direito à prova",21. Ressalta o autor que, no sistema inquisitório, a tarefa de investigar, de colher previamente o material probatório, era atribuída quase que exclusivamente aos órgãos estatais, encarregados oficialmente de tal função. Ou seja, a atividade de pesquisa probatória era confiada essencialmente ao juiz instrutor ou à polícia, no máximo ao órgão da acusação, mas nunca ao imputado. No modelo acusatório, a consagração do direito à prova gera a necessidade de permitir às partes, em especial ao acusado e seu defensor, que realizem atividades tendentes à descoberta de fontes de prova que serão utilizadas no processo.

A propósito, mostra-se pertinente neste momento realizar pequena digressão acerca das diferenças entre os modelos inquisitório e acusatório.

$\mathrm{Na}$ verdade, nos últimos tempos, muito tem se falado na inexistência de modelos acusatórios e inquisitórios puros, dada a dificuldade de encontrar nos ordenamentos jurídicos modelos inteiramente acusatórios, ou então totalmente inquisitórios ${ }^{122}$. Advém dessa constatação o entendimento de que os sistemas processuais penais de hoje ou são predominantemente acusatórios ou prevalentemente inquisitórios ${ }^{123}$.

Também é possível colher na doutrina pátria críticas à utilização da expressão sistema misto para designar aqueles ordenamentos em que predomina a forma inquisitiva na fase preparatória e a acusatória na fase processual ${ }^{124}$. JACINTO NELSON DE MIRANDA COUTINHO chama a atenção para o fato de que a própria noção de

\footnotetext{
${ }^{121}$ Cf. Direito à prova no processo penal, São Paulo, Revista dos Tribunais, 1997, p. 86.

122 Cf. GUSTAVO HENRIQUE IVAHY BADARÓ, Ônus da prova no processo penal, São Paulo, Revista dos Tribunais, 2003, pp. 101-102.

${ }^{123}$ Cf. PAULO CÉSAR BUSATO, De magistrados, inquisidores, promotores de justiça e samambaias - Um estudo sobre os sujeitos no processo em um sistema acusatório in $\mathrm{O}$ novo processo penal à luz da Constituição (Análise crítica do Projeto de Lei no 156/2009, do Senado Federal), Rio de Janeiro, Lumen Juris, 2010, p. 104.

${ }^{124}$ Cf. AURY LOPES JR., Introdução crítica ao processo penal (fundamentos da instrumentalidade garantista), $3^{\mathrm{a}}$ ed., Rio de Janeiro, Lumen Juris, 2005, pp. 168-169.
} 
sistema, baseada na idéia de um princípio unificador, impede que ele seja tido como misto $^{125}$.

Seja como for, mostra-se pertinente esclarecer quais características diferenciam ao menos em tese os aludidos sistemas.

O processo inquisitório é normalmente iniciado de ofício ${ }^{126}$ e seu procedimento se desenrola de modo secreto e através de atos escritos, o que dificulta sobremaneira, senão impossibilita, o exercício do contraditório e da ampla defesa ${ }^{127}$. Caracterizam ainda tal sistema o fato de a confissão do réu ser considerada a rainha das provas e o de os julgadores não estarem sujeitos à recusa ${ }^{128}$. Necessário também mencionar que, em matéria probatória, a busca da verdade não se dá de modo imparcial, normalmente a versão dos fatos aventada é desfavorável ao acusado ${ }^{129}$.

Já no processo acusatório, há separação entre as funções de investigar, acusar e julgar. Na verdade, a função investigatória pode ser atribuída a quem acusa ou a um terceiro órgão, a polícia, mas o que notabiliza tal sistema é o fato de que o juiz não pode ao mesmo tempo acusar e julgar ${ }^{130}$. Além disso, o processo não pode ser iniciado de ofício, e seu procedimento se desenrola com a observância aos princípios do contraditório, da ampla defesa, da publicidade e da oralidade ${ }^{131}$. O sistema se notabiliza ainda pela imparcialidade na busca da verdade no processo penal ${ }^{132}$.

Há também o chamado sistema misto, que contém características inerentes aos sistemas inquisitório e acusatório, as primeiras verificadas em geral na fase inicial da

\footnotetext{
${ }^{125}$ Sustenta o autor que, numa visão mais adequada da realidade, "os sistemas são mistos não por força da simples somatória de elementos que os integram, mas, fundamentalmente, porque em sendo sistemas regidos pelo princípio inquisitivo, têm agregados a si elementos provenientes do sistema acusatório" e "sendo regidos pelo princípio dispositivo, têm agregados a si elementos provenientes do sistema inquisitório". Cf. Cada parte no lugar constitucionalmente demarcado in Revista de Informação Legislativa, ano 46, $\mathrm{n}^{\circ}$ 183, edição especial, julho-setembro de 2009, pp. 108-109.

${ }^{126}$ Cf. GUSTAVO HENRIQUE IVAHY BADARÓ, Ônus da prova no processo penal, São Paulo, Revista dos Tribunais, 2003, p. 102.

${ }^{127}$ Sobre as origens e evolução histórica do processo inquisitório, veja-se JOÃO MENDES DE ALMEIDA JR., O processo criminal brasileiro, $4^{\mathrm{a}}$ ed., vol. I, São Paulo, Freitas Bastos, 1959, pp. 224-229.

${ }^{128}$ Cf. GUILHERME DE SOUZA NUCCI, Manual de processo penal e execução penal, $2^{\mathrm{a}}$ ed., São Paulo, Revista dos Tribunais, 2006, p. 103.

${ }^{129}$ Cf. NICOLA FRAMARINO DEI MALATESTA, A lógica das provas em matéria criminal, trad. Waleska Girotto Silverberg, vol. I, Conan Editora, 1995, p. 115.

${ }^{130}$ Cf. ADA PELLEGRINI GRINOVER, A iniciativa instrutória do juiz no processo penal acusatório in Revista Brasileira de Ciências Criminais, $n^{0}$ 27, São Paulo, Revista dos Tribunais, 1999, p. 71.

131 Aspectos históricos do processo acusatório foram objeto de análise por ANTONIO SCARANCE FERNANDES. Cf. Teoria geral do procedimento e o procedimento no processo penal, São Paulo, Revista dos Tribunais, 2005, pp. 76-77.

${ }^{132}$ Cf. NICOLA FRAMARINO DEI MALATESTA, A lógica das provas em matéria criminal, trad. Waleska Girotto Silverberg, vol. I, Conan Editora, 1995, p. 115.
} 
persecução (a exemplo da ausência de publicidade) e as segundas presentes na fase processual ou judicial (como a publicidade e a separação entre as funções de acusar e julgar) ${ }^{133}$.

Pois bem, para os fins deste trabalho, importa salientar que, em matéria de provas, a adoção do sistema acusatório e do processo penal de partes gera a necessidade de atribuir à acusação e à defesa todas as prerrogativas necessárias à efetivação de seu direito à prova, já que este decorre da própria idéia de contraditório e dos direitos de ação e de defesa, além do que não mais incumbe ao juiz a função de perseguir a verdade ou instruir o processo.

Desse modo, mostra-se indispensável num processo penal que se pretenda acusatório conferir às partes o direito não apenas de requerer e produzir provas, ou então de vê-las admitidas e apreciadas pelo magistrado, mas também o direito de pesquisá-las, de buscar suas fontes, de investigar o material que poderá subsidiar suas alegações durante toda a persecução penal.

Sobre o assunto, observa FLÁVIO LUIZ YARSHELL que nos sistemas de Common Law, o direito à prova e, por conseguinte, o direito à investigação, sempre foi reconhecido com maior facilidade, já que a iniciativa instrutória é incumbida preponderantemente às partes, ao passo que nos países de Civil Law, especialmente nos sistemas europeus continentais, a admissão do direito à prova encontra maior resistência pelo fato de que o juiz assume relevante papel na instrução, sendo dotado inclusive de poderes que lhe permitem determinar a realização de determinada prova para o melhor esclarecimento dos fatos ${ }^{134}$. Apenas em tempo mais recentes, por influência dos tratados internacionais de direitos humanos e das Constituições do pós-guerra, com extenso rol de direitos e garantias fundamentais, é que o direito à prova passou a ser admitido mais amplamente nesses ordenamentos da Europa continental ${ }^{135}$.

Para MANUEL DA COSTA ANDRADE, por exemplo, o processo penal americano é o que mais se aproxima de um modelo acusatório puro, pois as partes é que são incumbidas de investigar e reunir meios de provas (o juiz assume uma postura absolutamente passiva), ao passo que o processo penal alemão, embora também acusatório,

${ }^{133}$ Cf. MARCOS ALEXANDRE COELHO ZILLI, A iniciativa instrutória do juiz no processo penal, São Paulo, Revista dos Tribunais, 2003, p. 41.

${ }^{134} \mathrm{Cf}$. Antecipação da prova sem o requisito da urgência e direito autônomo à prova, São Paulo, Malheiros, 2009, p. 208.

${ }^{135}$ Cf. ADA PELLEGRINI GRINOVER, A marcha do processo, Rio de Janeiro, Forense Universitária, 2000, p. 449. 
é integrado por um princípio de investigação; o juiz é quem detém o domínio do processo, e está imbuído de poderes autônomos de investigação e de prova ${ }^{136}$.

Neste ponto, imperioso mencionar outra importante distinção entre modelos processuais penais verificados na atualidade. Utilizando como critério o sujeito ou órgão a quem incumbe a marcha do processo, os sistemas processuais penais podem ser classificados em inquisitoriais ou adversariais.

No sistema inquisitorial, há impulso oficial na condução do processo, ou seja, o juiz assume relevante papel no andamento do feito, sendo, por isso mesmo, dotado de amplos poderes instrutórios. Já no sistema dito adversarial, incumbe às partes, preponderantemente, a responsabilidade pela evolução do processo, o juiz fica praticamente inerte no que toca à marcha processual, e por tal razão o material probatório é trazido fundamentalmente pela acusação e pela defesa ${ }^{137}$.

Atente-se apenas para o fato de que as classificações do processo em acusatório/inquisitório e adversarial/inquisitorial costumam ser alvo de muitas confusões, as quais precisam ser desde logo desfeitas.

$\mathrm{Na}$ verdade, as aludidas categorias (acusatório/inquisitório e adversarial/inquisitorial) não se identificam: a primeira diz respeito, fundamentalmente, à existência ou não de atribuição a órgãos distintos das funções de acusar, defender e julgar $^{138}$, ao passo que a segunda refere-se, em síntese, ao grau de iniciativa probatória e de responsabilidade pelo andamento do processo concedido às partes e ao juiz. Logo, um processo acusatório pode ser regido tanto pelo sistema adversarial como pelo inquisitorial $^{139}$.

Pois bem, seja nos países de Common Law, típicos de sistema adversarial, seja nos países de tradição continental, em que predomina o modelo inquisitorial de marcha processual, o direito à investigação deve ser reconhecido como desdobramento necessário do direito à prova, pois, mesmo nas nações em que o juiz é dotado de poderes instrutórios, às partes é conferido o direito à prova como decorrência lógica da adoção do

\footnotetext{
${ }^{136}$ Cf. Sobre as proibições de prova em processo penal, Coimbra, Coimbra Editora, 2006, pp. 137-138.

${ }^{137}$ Cf. MARCOS ALEXANDRE COELHO ZILLI, A iniciativa instrutória do juiz no processo penal, São Paulo, Revista dos Tribunais, 2003, pp. 42-44.

${ }^{138}$ Cf. GUSTAVO HENRIQUE IVAHY BADARÓ, Ônus da prova no processo penal, São Paulo, Revista dos Tribunais, 2003, p. 102.

${ }^{139}$ Cf. ADA PELLEGRINI GRINOVER, A iniciativa instrutória do juiz no processo penal acusatório in Revista Brasileira de Ciências Criminais, nº 27, São Paulo, Revista dos Tribunais, 1999, p. 27.
} 
princípio acusatório e das garantias a ele inerentes, como o contraditório, o direito de ação e o direito de defesa.

\subsection{NATUREZA JURÍDICA}

Vistos, pois, o conceito e o fundamento jurídico do direito à investigação, não se poderia deixar de aludir à sua natureza jurídica.

Entendido o direito à investigação como uma das prerrogativas inerentes ao direito à prova, razoável supor que apresente aquele a mesma natureza jurídica deste, qual seja a de um direito subjetivo que pode ser exercido pelas partes em decorrência dos próprios direitos de ação e de defesa.

Neste ponto, mostra-se válido recordar a lição de ADA PELLEGRINI GRINOVER, para quem ação e defesa são face e verso da mesma medalha, garantias correlatas e justapostas que atuam sobre componentes idênticos e asseguram o justo processo, bem como o contraditório, que também as garante ${ }^{140}$.

Mesmo o jurista FLÁVIO LUIZ YARSHELL, que enxerga na atividade probatória um dever das partes, relacionado ao princípio de lealdade e aos deveres de veracidade e de colaboração, reconhece na investigação um direito ou prerrogativa que integra o conteúdo do chamado direito à prova ${ }^{141}$.

E, uma vez que a investigação consiste num direito subjetivo das partes, decorrente do direito à prova, ligado, ainda que indiretamente, aos direitos de ação e de defesa, é possível afirmar que o direito à investigação igualmente constitui um direito público ou cívico ${ }^{142}$ : tem como sujeito passivo o Estado, que, através de suas autoridades, efetiva os requerimentos relacionados ao exercício da atividade instrutória ${ }^{143}$.

Aliás, na etapa inicial da persecução penal brasileira, também chamada de instrução preliminar ou prévia, é assegurado à acusação o direito de requisitar diligências à autoridade policial (art. 13, II, CPP), e ao imputado e ao ofendido é garantido

\footnotetext{
${ }^{140}$ Cf. O processo constitucional em marcha, São Paulo, Max Limonad, 1985, pp. 10-11.

${ }^{141}$ Cf. Antecipação da prova sem o requisito da urgência e direito autônomo à prova, São Paulo, Malheiros, 2009, p. 195.

142 Cf. ANTONIO SCARANCE FERNANDES, Processo penal constitucional, $6^{\mathrm{a}}$ ed., São Paulo, Revista dos Tribunais, 2010, p. 80.

${ }^{143}$ Cf. ANTONIO MAGALHÃES GOMES FILHO, Direito à prova no processo penal, São Paulo, Revista dos Tribunais, 1997, P. 84.
} 
expressamente ao menos o direito de requerer diligências à polícia, as quais poderão ou não ser realizadas, a juízo da autoridade competente (art. 14, CPP).

Ainda que o direito à investigação não se restrinja a tais prerrogativas, como se verá adiante, cabe desde logo salientar que o Código de Processo Penal brasileiro, pela redação dos dispositivos supracitados, concede nítido tratamento diferenciado ao direito à investigação da acusação e da defesa, especificamente no que diz respeito à sua relação com a atividade investigativa da polícia. Todavia, há quem sustente que, tal como ocorre com o órgão da acusação, não pode a autoridade policial deixar de realizar as diligências requeridas pela defesa, e mesmo pela vítima. A interpretação decorre da releitura dos dispositivos mencionados à luz dos princípios da igualdade e, principalmente, da ampla defesa, ambos assegurados pela Constituição Federal de $1988^{144}$.

Ao analisar o art. 14 do Código de Processo Penal pátrio, já dizia JOAQUIM CANUTO MENDES DE ALMEIDA que a cláusula "a juízo da autoridade" está relacionada ao poder-dever inquisitivo do delegado de polícia na condução de seu mister, de modo que não deve representar restrição ao direito de defesa, muito menos abuso de $\operatorname{poder}^{145}$.

Acrescenta ainda MARTA SAAD que a autoridade policial só poderá deixar de realizar diligências requeridas pela defesa se as mesmas se revelarem inviáveis ou inócuas, e mesmo assim, a decisão deverá ser devidamente fundamentada. Se os atos instrutórios forem relevantes e pertinentes à apuração das circunstâncias do crime e ao exercício do direito de defesa do acusado, não poderá o delegado indeferir sua realização; o contrário autoriza o investigado a valer-se de mandado de segurança, ou mesmo habeas $\operatorname{corpus}^{146}$, para ver assegurado seu direito de defesa, e, no fim, seu direito à investigação.

A doutrina mais tradicional, no entanto, sustenta que os requerimentos de diligências formulados pela defesa, e pela vítima também, podem ou não ser deferidos pela autoridade policial, segundo seu critério ${ }^{147}$.

${ }^{144}$ Cf. MARTA SAAD, O Direito de Defesa no Inquérito Policial, São Paulo, Revista dos Tribunais, 2004, p. 351. No mesmo sentido, veja-se ANDRÉ AUGUSTO MENDES MACHADO, Investigação criminal defensiva, São Paulo, Revista dos Tribunais, 2010, p. 117.

${ }_{145}$ Cf. Principios Fundamentais do Processo Penal, São Paulo, Revista dos Tribunais, 1973, p. 213.

${ }^{146}$ Cf. O Direito de Defesa no Inquérito Policial, São Paulo, Revista dos Tribunais, 2004, p. 352.

${ }^{147}$ Cf. JULIO FABBRINI MIRABETE, Código de processo penal interpretado, $11^{\mathrm{a}}$ ed., São Paulo, Atlas, 2006, pp. 118-119. 
A propósito, em relação ao $\S 3^{\circ}$ do art. 159 do Código Processo Penal ${ }^{148}$, introduzido pela Lei $\mathrm{n}^{\mathrm{o}} 11.690 / 08$ e que veio a permitir a formulação de quesitos e a indicação de assistente técnico pelas partes, há quem sustente que, em se tratando de perícias realizadas na fase investigativa, apenas o possível titular da ação penal (Ministério Público ou querelante) é que poderia formular quesitos, e que a indicação de assistente técnico só pode se dar na fase judicial da persecução penal. Nesse sentido, por exemplo, o posicionamento de ANTONIO MAGALHÃES GOMES FILHO ${ }^{149}$ e MARCELLUS POLASTRI LIMA ${ }^{150}$. No entanto, há importantes vozes dissonantes, que defendem a possibilidade de as partes, amplamente consideradas, indicarem assistentes técnicos e formularem quesitos aos peritos já durante a instrução preliminar. Nas palavras de ANTONIO SCARANCE FERNANDES, "o fato de constar do inc. II do $\S 5^{\circ}$ do art. 159 , que será permitido às partes indicar assistentes técnicos durante o curso de processo judicial não pode ser entendido como regra restritiva no sentido de que a indicação não possa acontecer durante a fase de investigação. O parágrafo anterior possibilita, de forma ampla, ao perito atuar sempre que concluídos os exames e elaborado o laudo pelos peritos oficiais. A sua atuação antes de ser oferecida a acusação pode ser relevante para esclarecer pontos essenciais para a verificação da justa causa para a ação penal" "151.

Seja como for, importa ressaltar neste ponto que, apesar de nosso ordenamento jurídico conferir prerrogativas diferenciadas para acusação, defesa e vítima no que diz respeito ao exercício do direito à investigação, possui o mesmo a natureza de um direito subjetivo público assegurado às partes, ainda que eventuais, no processo penal.

\subsection{TITULARIDADE}

Também aqui tomando por base a premissa de que o direito à investigação é um dos corolários do direito à prova, forçoso concluir que os titulares daquele direito não poderiam deixar de ser os mesmos a quem foi atribuído o direito à prova, ou seja, às partes no processo penal, sejam elas necessárias (titular da ação penal e acusado, que

\footnotetext{
${ }^{148}$ Eis a previsão do art. $159, \S 3^{\circ}$ do CPP: "serão facultados ao Ministério Público, ao assistente de acusação, ao ofendido, ao querelante a ao acusado a formulação de quesitos e indicação de assistente técnico".

${ }^{149}$ Cf. Provas - Lei 11.690, de 09.06.2008 in As reformas no processo penal - as novas leis de 2008 e os projetos de reforma, coord. Maria Thereza Rocha de Assis Moura, São Paulo, Revista dos Tribunais, 2008, pp. 277-278.

${ }^{150}$ Cf. A prova penal de acordo com a reforma processual penal, $3^{\text {a }}$ ed., Rio de Janeiro, Lumen Juris, 2009, pp. 144-147.

${ }^{151}$ Cf. Processo penal constitucional, $6^{a}$ ed., São Paulo, Revista dos Tribunais, 2010, p. 80.
} 
personificam as figuras da acusação e defesa), ou eventuais/contingentes (assistente de acusação).

Há, no entanto, uma importante diferença entre os titulares do direito à prova e do direito à investigação, que precisa desde logo ser ressaltada: como o último direito é exercido, principalmente, na etapa inicial da persecução penal ${ }^{152}$, não se mostra totalmente correto aduzir que o direito à investigação tem como titulares pura $\mathrm{e}$ simplesmente as partes, pois sequer existe processo propriamente dito nesta fase de instrução $\operatorname{preliminar}^{153}$.

Afigura-se, assim, mais acertado afirmar que os titulares do direito à investigação são as possíveis partes de um processo penal, ou seja, todos aqueles sobre os quais recair a mera possibilidade de atuar como partes necessárias ou eventuais num futuro processo penal.

Atente-se para o fato de que não se deve exigir nem a condição de provável parte para assegurar o direito à investigação na fase instrutória preliminar ${ }^{154}$, afinal, o direito deve ser garantido também aos investigados ditos inocentes, justamente para que possam demonstrar a inexistência de justa causa para a ação penal.

Em outras palavras, o direito à investigação deve ser conferido não apenas aos indiciados, mas também aos suspeitos, e a todos aqueles a quem, na condição de possíveis partes, possa interessar a colheita de informações já nesta etapa da persecução penal.

Nesse sentido, mostra-se pertinente salientar que o titular da ação penal, pública ou privada, também tem direito a investigar, a colher elementos de informação

\footnotetext{
${ }^{152}$ Como se verá adiante (item 2.4), o direito à investigação não é exercido apenas na etapa inicial da persecução penal.

${ }^{153}$ Também para AURY LOPES JR. constitui um equívoco falar em partes na instrução preliminar pois, entre outras razões, na etapa inicial da persecução penal ainda não há processo, tampouco o exercício de uma pretensão e a correlativa resistência. Cf. Sistemas de investigação preliminar no processo penal, Rio de Janeiro, Lumen Juris, 2001, p. 261.

154 Lembre-se, neste ponto, a lição de AURY LOPES JR., aplicável analogamente à hipótese: "existe possibilidade em lugar de probabilidade quando as razões favoráveis ou contrárias à hipótese são equivalentes. O juízo de possibilidade prescinde da afirmação de um predomínio das razões positivas sobre as razões negativas e vice-versa. Para a abertura do inquérito policial (ou qualquer outro instrumento de investigação preliminar) seria suficiente um juízo de possibilidade, posto que no curso da investigação se irão aportando outros elementos que permitam um maior grau de convencimento. Inobstante, para a admissão de uma ação penal ou aplicação de uma medida cautelar pessoal, é necessário mais do que isso, deve existir um juizo de probabilidade, uma predominância das razões positivas. Se a possibilidade basta para a imputação, não pode bastar para a acusação, pois o peso do processo agrava-se notavelmente sobre as costas do imputado”. Cf. Sistemas de investigação preliminar no processo penal, Rio de Janeiro, Lumen Juris, 2001, pp. 54-55.
} 
relativos às circunstâncias do crime nesta fase anterior ao processo, até para evitar acusações equivocadas. Logo, ao Ministério Público e ao querelante, como possíveis partes acusadoras na ação penal, também é assegurada a titularidade do direito à prova.

Cabível, no entanto, perquirir se, nas hipóteses em que não é possível desde logo aferir se a ação penal será de iniciativa pública ou privada, a vítima poderia investigar, uma vez que não se admite assistente de investigação na fase de instrução prévia, segundo dispõe o art. 268 do Código de Processo Penal pátrio ${ }^{155}$.

Nessas situações limítrofes, a solução que parece mais acertada é assegurar o direito à investigação também à vítima, ainda que de forma mais restrita, uma vez que, como dito acima, mais que às prováveis partes na futura ação penal, é às possíveis partes que deve ser garantido o direito de colher elementos de informação relativos ao fato criminoso e demais questões relevantes atinentes à pena, à culpabilidade, à satisfação de interesses civis, entre outros.

Até para o fim de atribuir corretamente a iniciativa da ação penal a atividade investigativa pode se revelar importante, de modo que se afigura mais correto o entendimento segundo o qual a vítima também é titular do direito à investigação, mesmo quando não se tenha absoluta certeza de que a iniciativa da ação penal será privada no caso concreto.

Nesta hipótese de dúvida acerca da titularidade da ação penal, porém, talvez fosse recomendável apenas que a atividade probatória do ofendido se limitasse à de auxílio ao órgão/autoridade oficialmente incumbidos de investigar. A regra, assim concebida, não afastaria por completo a participação da vítima e possível querelante nesta fase investigativa, e tampouco causaria patente desequilíbrio entre acusação e defesa, já que a garantia de direito irrestrito de investigação tanto ao órgão estatal de acusação como à vítima nestas situações em que não se tem certeza sobre quem é o titular da ação penal colocaria o suspeito em posição flagrantemente desfavorável em relação àqueles.

Em Portugal, por exemplo, o assistente de acusação é admitido já na instrução preliminar, mas na condição de colaborador subordinado ao Ministério Público, podendo, basicamente, apresentar memoriais ou requerer diligências probatórias, que serão

${ }^{155}$ Não é demasiado mencionar uma vez mais o conteúdo do referido dispositivo: "Art. 268. Em todos os termos da ação pública, poderá intervir, como assistente do Ministério Público, o ofendido ou seu representante legal, ou, na falta, qualquer das pessoas mencionadas no art. 31" (leia-se cônjuge, ascendente, descendente ou irmão). 
realizadas ou não a juízo do Parquet, com base na relevância das medidas para a demonstração dos fatos ${ }^{156}$. A regra poderia ser transportada, com as devidas adaptações, para o ordenamento brasileiro.

Neste ponto, mostra-se pertinente mencionar o posicionamento do jurista italiano ANDREA ANTONIO DALIA, para quem o direito à investigação deve ser atribuído não apenas à acusação e à defesa, mas também à vítima do crime, que, nesse sentido, auxiliaria a atividade instrutória estatal ${ }^{157}$.

Não custa lembrar, é claro, que neste momento só se está a verificar quem são os titulares em tese do direito à investigação; o modo pelo qual o exercício de tal direito se daria, e as vantagens e inconvenientes da ampliação de suas prerrogativas para além daquelas previstas hoje expressamente em nosso ordenamento jurídico, serão melhor debatidos adiante ${ }^{158}$.

Por fim, registre-se que, num sistema que se pretenda acusatório, ao juiz não deve ser atribuído o direito à investigação: o magistrado até pode dispor de certos poderes instrutórios $^{159}$, o que não significa que ele tenha o direito a investigar.

Aliás, justamente por isso é que muito se tem criticado a previsão do art. 156, I, do Código de Processo Penal brasileiro, com a redação que lhe foi dada pela Lei ${ }^{\circ}$ 11.690/08. O dispositivo faculta ao juiz, de ofício, ordenar, mesmo antes de iniciada a ação penal, a produção de provas consideradas urgentes e relevantes, observando a necessidade, a adequação e a proporcionalidade da medida.

\footnotetext{
${ }^{156}$ Cf. JORGE DE FIGUEIREDO DIAS, Direito processual penal, Coimbra, Coimbra Editora, 2004, p. 522.

${ }^{157}$ Nesse sentido, afirma o autor que o direito a investigar "vale tanto para o promotor - que é o titular do poder de investigação para a procura de fontes que sustentem a acusação - quanto para a pessoa ofendida pelo crime - que pode desenvolver uma atividade de suporte à atividade institucional do promotor - e, com maior razão, para a pessoa submetida às investigações, interessada em pesquisar aquilo que pretende apresentar, depois, ao juiz, para mostrar a ausência de culpa". Cf. Manuale di diritto processuale penale, $4^{\mathrm{a}}$ ed., Padova, CEDAM, 2001, p. 203. O trecho mencionado foi traduzido livremente do que segue transcrito: [o direito à investigação] "vale tanto per il magistrato del pubblico ministero - che è il titolare del potere d'investigazione alla ricerca delle fonti a sostegno dell'accusa - quanto per la persona offesa dal reato - che può svolgere un'attività di supporto all'attività istituzionale del magistrato - e, a maggior ragione, per la persona sottoposta alle indagini, interessata a ricercare quanto intende rappresentare, poi, al giudice, in funzione di discolpa".

${ }^{158}$ Ver Capítulo IV.

${ }^{159}$ MARCOS ALEXANDRE COELHO ZILLI afirma categoricamente que a "iniciativa instrutória a cargo do juiz, por si só, não é incompatível com a modelagem acusatória”. Cf. A iniciativa instrutória do juiz no processo penal, São Paulo, Revista dos Tribunais, 2003, p. 272. No mesmo sentido a opinião de MICHELLE TARUFFO, que, todavia, ressalva que os poderes instrutórios do magistrado devem ser acessórios e complementares à iniciativa probatória das partes. Cf. Simplesmente la verdad - El juez y la construcción de los hechos, trad. Daniela Accatino Scagliotti, Madrid, Marcial Pons, 2010, p. 199.
} 
Há quem sustente até a inconstitucionalidade do dispositivo, por representar uma afronta ao processo de partes, acusatório, e ao princípio da imparcialidade do juiz ${ }^{160}$. No entanto, como bem observa ANTONIO MAGALHÃES GOMES FILHO, o art. 156, I, pode ser interpretado à luz da Constituição Federal de 1988, e de uma visão sistemática da Lei 11.690/08 (que visou a sublinhar os traços distintivos entre provas e elementos informativos da investigação), o que afasta a idéia de juiz investigador que muitos têm propalado $^{161}$.

Segundo o jurista, ao dizer "que o juiz pode determinar produção antecipada de provas consideradas urgentes e relevantes, a lei não contempla outra coisa senão a iniciativa judicial para a antecipação de atos tendentes à formação de provas não de elementos de investigação -, diante do risco de desaparecimento ou deterioração de fontes de informação. São, por exemplo, os casos de depoimentos antecipados, perícias urgentes etc. - que até mesmo podem resultar em provas destinadas a demonstrar teses defensivas -, que, de outro modo, estariam comprometidos pela ação do tempo",162.

Também para MARCELLUS POLASTRI LIMA o dispositivo deve ser entendido segundo uma interpretação conforme à Constituição, de modo que o juiz só pode ordenar a realização de provas na fase investigatória se houver pedido das partes neste sentido $^{163}$.

Em suma, conclui-se que o direito à investigação não deve ser conferido ao juiz, mas sim às partes, ainda que potenciais, a fim de que exerçam plenamente as garantias constitucionais que lhes são asseguradas.

É bem verdade que, normalmente, o vocábulo investigação remete a atos ou procedimentos conduzidos por autoridades públicas, sendo praticamente inconcebível a idéia de investigações realizadas por particulares, principalmente na seara criminal. Mas é justamente tal visão que precisa ser desfeita, uma vez que tanto à acusação como à defesa,

\footnotetext{
${ }^{160}$ Cf. NEREU JOSÉ GIACOMOLLI, A fase preliminar do processo penal - Crises, misérias e novas metodologias investigatórias, Rio de Janeiro, Lumen Juris, 2011, p. 47.

${ }^{161}$ Cf. Provas - Lei 11.690, de 09.06.2008 in As reformas no processo penal - as novas leis de 2008 e os projetos de reforma, coord. Maria Thereza Rocha de Assis Moura, São Paulo, Revista dos Tribunais, 2008, p. 261.

${ }^{162}$ Cf. Provas - Lei 11.690, de 09.06.2008 in As reformas no processo penal - as novas leis de 2008 e os projetos de reforma, coord. Maria Thereza Rocha de Assis Moura, São Paulo, Revista dos Tribunais, 2008, p. 261.

${ }^{163}$ Cf. A prova penal de acordo com a reforma processual penal, $3^{\mathrm{a}}$ ed., Rio de Janeiro, Lumen Juris, 2009, pp. 45-46.
} 
aqui englobados o acusado e seu defensor, e também à vítima, é assegurado o direito à prova, que implica também o direito de investigar fatos de seu interesse na esfera criminal.

Não se está aqui a negar que órgãos ou agentes estatais realizam atos investigatórios, pelo contrário, reconhece-se que a maioria, quase a totalidade, das investigações são conduzidas por funcionários ou instituições do Estado, até em observância a ditames constitucionais e legais.

No entanto, o que se quer enfatizar é que, no processo penal, o reconhecimento de um direito à prova de titularidade das partes gera também o direito de buscar as fontes, o material probatório necessário à demonstração da veracidade de suas asserções, ao longo de toda a persecução penal. Desse modo, forçoso reconhecer que acusação, defesa e vítima também são titulares do direito à investigação ${ }^{164}$.

Idêntico posicionamento é defendido por FLÁVIO LUIZ YARSHELL, para quem a idéia de investigação não deve ser limitada à busca da prova por agentes públicos. Nas palavras do próprio autor, "a investigação deve ser vista genericamente como prerrogativa que, tendo origem no direito à prova, ganha autonomia e não se limita à seara dos órgãos públicos ${ }^{\text {"165 }}$. Sustenta ainda o jurista que não deve ser conferida maior ou menor credibilidade à investigação pelo fato de ser ela realizada ou não por agentes estatais. Tanto a investigação privada como a pública estão sujeitas a excessos e, por isso mesmo, devem se submeter a controle jurisdicional, prévio ou posterior ${ }^{166}$.

\subsection{CONTEÚDO E FINALIDADES}

\footnotetext{
164 Também sustenta que o direito à investigação deve ser reconhecido tanto ao órgão acusador quanto ao imputado GUSTAVO HENRIQUE IVAHY BADARÓ. Ao tratar do tema, observou o jurista que, "reconhecido o direito de investigação da acusação, em respeito ao princípio da igualdade de partes, deverá ser conferido igual direito à defesa”. Cf. Direito processual penal, Tomo I, Rio de Janeiro, Elsevier, 2008, p. 204.

${ }^{165}$ Cf. Antecipação da prova sem o requisito da urgência e direito autônomo à prova, São Paulo, Malheiros, 2009, p. 217.

${ }^{166}$ Cf. Antecipação da prova sem o requisito da urgência e direito autônomo à prova, São Paulo, Malheiros, 2009, pp. 219-220. Complementa ainda o jurista que "a pesquisa de fatos e a busca da prova - não obstante a presunção de legitimidade dos atos administrativos e, de um modo geral, dos atos que emanam do Estado - não devem ser tidas por incensuráveis tão-somente porque provém de certa autoridade; como, por outro lado, não se pode presumir ilegítima ou viciada a investigação que o ente privado busque realizar só pela circunstância de provir de alguém que não seja autoridade. Uma e outra devem considerar que a busca da prova, por si só, representa uma forma de invasão da esfera individual, e isso deve ser considerado quer se trate de investigação de fatos presidida por autoridade, quer se trate de investigação cuja iniciativa parta de ente privado".
} 
Questão das mais interessantes no estudo do direito à investigação é delimitar seu conteúdo, o qual está diretamente relacionado às suas finalidades.

Imprescindível esclarecer desde já que o direito à investigação pode ser exercido desde a fase anterior ao processo ou mesmo no curso deste ${ }^{167}$. É claro que a própria idéia de investigação remete à etapa prévia ao processo penal propriamente dito, em que se realizam atos tendentes a verificar as circunstâncias em que ocorreu o delito. Todavia, é possível falar-se no direito à investigação também depois de já instaurado o processo, pois a qualquer momento pode surgir a necessidade de esclarecer determinados fatos $^{168}$.

$\mathrm{Na}$ verdade, o que se quer dizer é que, com a propositura da ação penal, não necessariamente já se conhecem todos os fatos relevantes relacionados à causa. É ilusória a idéia de que, no curso da instrução propriamente dita, meramente se provam as afirmações feitas pelas partes com base no que chegou a seu conhecimento através dos atos realizados na etapa anterior da persecução penal.

Depois de iniciado o processo, também se pode fazer necessário o exercício do direito à investigação com vistas à obtenção de material probatório ${ }^{169}$. Porém, normalmente, ao se abordar a atividade investigatória, está-se a referir à fase préprocessual da persecução penal.

A propósito, costuma-se afirmar que o direito à investigação tem como finalidade principal permitir às partes a busca de provas. PAOLO TONINI, por exemplo,

${ }^{167} \mathrm{O}$ jurista PAOLO TONINI, por exemplo, assevera que o direito à investigação, a pesquisar as provas, deve ser conferido às partes durante todo o procedimento probatório. Cf. A prova no processo penal italiano, trad. Alexandra Martins e Daniela Mróz, São Paulo, Revista dos Tribunais, 2002, p. 84.

${ }^{168}$ No processo penal italiano, por exemplo, a melhor doutrina entende que as investigações defensivas não encontram qualquer limite temporal, podem ser exercidas quando a investigação estatal já estiver em curso, ou antes mesmo de sua instauração, e até em sede de execução e no procedimento de revisão. Cf. PASQUALE VENTURA, Le indagine difensive, Milano, Giuffrè, 2005, pp. 45 e 57.

${ }^{169}$ Ao analisar o assunto sob a ótica do processo civil, FLÁVIO LUIZ YARSHELL teceu importantes considerações a esse respeito, aplicáveis analogamente ao processo penal: "não se pode pensar na investigação prévia como substancialmente distinta - especialmente quanto aos respectivos limites - da investigação que, afinal de contas, também se realiza no bojo do processo". Prosseguiu ainda o autor: "certo que, até mesmo em termos lógicos, uma coisa é provar fatos já conhecidos, e outra é conhecer os fatos através da produção de provas. Em tese, a primeira teria lugar no processo declaratório, e a segunda no momento da investigação preliminar. Mas o problema reside justamente aí: não parece correto afirmar que quem provoca a instauração do processo de conhecimento declaratório já conheça os fatos e que, naquele momento, precise apenas prová-los. O que pode existir nesse momento - exceção feita à prova que, por sua natureza, já seja pré-constituída - é afirmação do autor (e também do réu) de que os fatos se passaram desta ou daquela forma". (... ) "Assim, a convicção da parte sobre os fatos não significa dizer que eles precisam ser apenas provados, como se, então, a instrução no processo declaratório fosse apenas ratificar o que afirmou a parte. A instrução que se realiza dentro do processo declaratório, inclusive a depender do meio de prova do qual se cogite, também envolve o que se poderia entender como investigação". Cf. Antecipação da prova sem o requisito da urgência e direito autônomo à prova, São Paulo, Malheiros, 2009, pp. 220-221. 
defende que à acusação e à defesa deve ser permitido buscar as provas, porque ninguém melhor do que as partes para compreender quais elementos são adequados à formação do convencimento judicial $^{170}$.

Como já visto, o vocábulo prova comporta vários significados, sobretudo no que respeita à ciência processual. Perfeitamente cabível, portanto, perquirir em que sentido deve ser compreendido o termo prova quando se afirma que o direito à investigação consiste, basicamente, no direito a pesquisar provas.

A doutrina, em geral, sustenta que no exercício do direito à investigação, as partes procuram fontes de prova ${ }^{171}$. Neste ponto, conveniente recordar o que se deve entender por fontes de prova. No capítulo anterior, fontes de prova foram definidas como as pessoas ou coisas através das quais se pode conseguir a prova, ou seja, tudo aquilo que é idôneo a fornecer resultado apreciável para a decisão judicial.

Não custa também reafirmar a observação então feita de que as fontes de prova são anteriores ao processo: elas decorrem dos fatos em si, existem independentemente do processo, são todas as pessoas e coisas que podem servir ao esclarecimento dos fatos cuja reconstrução se busca.

Na lição de RUBÉN A. CHAIA, as fontes de prova são anteriores e estranhas ao processo, têm independência em relação a este ${ }^{172}$. No mesmo sentido é a posição de CÂNDIDO RANGEL DINAMARCO, para quem são fontes de prova os elementos externos em si mesmos, quando considerados em sua aptidão a fornecer indicações úteis ao julgamento ${ }^{173}$.

Corrobora o entendimento de que através do exercício do direito à investigação são obtidas fontes de prova o fato de que a descoberta destas pode até evitar a propositura da ação penal e o início do processo. Ou seja, tanto as fontes de prova existem independentemente do processo que podem até servir como meio de evitá-lo.

\footnotetext{
${ }^{170}$ Cf. A prova no processo penal italiano, trad. Alexandra Martins e Daniela Mróz, São Paulo, Revista dos Tribunais, 2002, p. 84.

${ }^{171}$ Tal posicionamento é defendido, por exemplo, por PAOLO TONINI em sua obra $A$ prova no processo penal italiano, trad. Alexandra Martins e Daniela Mróz, São Paulo, Revista dos Tribunais, 2002, p. 83, e por GUSTAVO HENRIQUE RIGHI IVAHY BADARÓ em seu livro Direito processual penal, Tomo I, Rio de Janeiro, Elsevier, 2008, p. 83.

${ }_{172}$ Cf. La prueba en el proceso penal, Buenos Aires, Hammurabi, 2010, pp. 87-88.

${ }^{173}$ Cf. Instituições de direito processual civil, vol. III, São Paulo, Malheiros, 2001, p. 86.
} 
ANTONIO MAGALHÃES GOMES FILHO já chamava a atenção para o fato de que o direito à investigação deve ser assegurado até para fins de embasamento da persecução ou seu impedimento ${ }^{174}$.

Na verdade, mesmo quando da análise da investigação criminal como mera etapa inicial da persecução penal já se destacava sua função de impedir a formulação de acusações infundadas ou processos penais descabidos.

Normalmente, é apontada como principal finalidade da investigação criminal a colheita das informações necessárias à propositura ação penal ${ }^{175}$. No entanto, a instrução preliminar ou prévia possui ainda outras importantes funções, entre as quais evitar processos desnecessários e acusações equivocadas ${ }^{176}$.

Aludida finalidade da instrução preliminar foi designada por JOAQUIM CANUTO MENDES DE ALMEIDA como a função preventiva da investigação criminal. O autor, aliás, classifica as funções da investigação criminal em preventiva e preparatória. A primeira "decorre da necessidade de fundamentar um juizo de acusação, isto é, um julgamento prévio dos elementos acusatórios, quer para garantia da inocência contra a leviandade ou calúnia, quer para garantia do organismo jurisdicional contra os dispêndios inúteis e injustos de tempo e de trabalho”, enquanto a segunda é determinada "pela necessidade de produção, antes e fora da audiência, de provas dificilmente realizáveis no tempo e no local de concentração do processo" ${ }^{177}$.

E, considerando as finalidades do direito à investigação acima referidas, é possível afirmar que, tal como ocorre com o direito à prova, seu objeto não é apenas o fato criminoso, a prova da materialidade e os indícios de autoria, mas também todas as circunstâncias relevantes do delito, como as relativas à tipicidade formal e material, ilicitude e eventuais excludentes, elementos da culpabilidade, fatores relacionados à punibilidade, à satisfação de interesses civis da vítima, entre outros.

\footnotetext{
${ }^{174}$ Cf. Direito à prova no processo penal, São Paulo, Revista dos Tribunais, 1997, p. 86. Nas palavras do autor, "o direito à prova também deve ser reconhecido antes e fora do processo, até como meio de se obter elementos que autorizem a persecução, ou possam evitá-la”.

${ }^{175}$ Cf. ROGÉRIO LAURIA TUCCI, Persecução penal, prisão e liberdade, São Paulo, Saraiva, 1980, p. 19, e JOSÉ FREDERICO MARQUES, Elementos de direito processual penal, vol. I, $2^{\mathrm{a}}$ ed., Campinas, Millenium, 2000 , p. 152.

${ }^{176}$ FAUZI HASSAN CHOUKR salienta que “este momento inicial (da persecução penal) é marcado por uma precariedade de informes considerável, não sendo possível um controle aprofundado acerca da existência ou não de algo a ser apurado em sede criminal, donde a importância de cercar-se esse momento contra as investidas arbitrárias”. Cf. Garantias constitucionais na investigação criminal, $2^{\mathrm{a}}$ ed., Rio de Janeiro, Lumen Juris, 2001, p. 79.

${ }^{177}$ Cf. Princípios fundamentais do processo penal, São Paulo, Revista dos Tribunais, 1973, p. 30.
} 
Acrescenta NEREU JOSÉ GIACOMOLLI que "de mero filtro procedimental (finalidade imediata) a fase investigatória recolhe importantes elementos, cujos reflexos atingem o status de cidadão, sua esfera patrimonial e pessoal, com o fornecimento de base aos rumos do procedimento, ao arquivamento, ao deferimento ou não de medidas cautelares constritivas da liberdade (prisão preventiva, v. g.) e dos bens (arresto, seqüestro, v. g.), bem como delimitam a pretensão acusatória estatal (oferecimento de denúncia) ${ }^{\prime \prime 178 .}$

E se o exercício do direito à investigação, e esta em si, servem justamente para subsidiar a acusação, ou mesmo evitá-la, além de fornecer supedâneo para decisões na fase instrutória preliminar e eventuais provas a serem utilizadas no processo, forçoso ainda concluir que os destinatários das fontes de provas colhidas no exercício do direito à investigação são as próprias partes.

Explique-se melhor: o direito à investigação, consistente no direito subjetivo de buscar e colher material probatório apto ao esclarecimento dos fatos penais, tem as partes como titulares e ao mesmo tempo destinatários de tal direito, titulares porque, como já visto, é à acusação, à defesa e à vítima que é atribuído tal direito, e destinatários, porque é aos mesmos referidos sujeitos que se destinam as informações obtidas na investigação, mais do que ao juiz.

GUSTAVO HENRIQUE IVAHY BADARÓ, por exemplo, afirma categoricamente que as fontes de prova, colhidas no exercício do direito à investigação, destinam-se precipuamente às partes, que têm disponibilidade sobre as mesmas, pois são quem melhor conhece os fatos ${ }^{179}$. O magistrado não pode buscar fontes de prova, sob pena de comprometer sua imparcialidade; a ele destinam-se os meios de prova, que são os instrumentos através dos quais os elementos de prova, os dados objetivos descobertos, são introduzidos no processo $^{180}$.

Ressalte-se apenas que a assertiva de que as fontes de prova destinam-se às partes e não ao juiz não implica que, chegando ao conhecimento do magistrado informações sobre fontes de prova, devam estas ser simplesmente desconsideradas. $\mathrm{O}$ julgador pode, no exercício de seus poderes instrutórios, determinar a realização do meio

\footnotetext{
${ }^{178}$ Cf. A fase preliminar do processo penal - Crises, misérias e novas metodologias investigatórias, Rio de Janeiro, Lumen Juris, 2011, p. 58.

${ }^{179}$ Cf. Onus da prova no processo penal, São Paulo, Revista dos Tribunais, 2003, p. 167.

${ }^{180}$ Cf. LUIGI PAOLO COMOGLIO, Prove ed accertamento dei fatti nel nuovo C.P.P. in Rivista Italiana di Diritto e Procedura Penale, ano 33, Milano, Giuffrè Editore, 1990, p. 145.
} 
de prova necessário à incorporação ao processo dos elementos informativos fornecidos pela respectiva fonte.

E o entendimento de que o exercício do direito à investigação tem como destinatários as próprias partes e objetiva, entre outras coisas, evitar ações penais infundadas e descabidas, permite chegar ainda a outra conclusão, de extrema importância: o direito à investigação é um direito autônomo, existe independentemente do processo, embora esteja a ele diretamente relacionado.

Ainda que, como dito alhures, o direito à investigação possa ser exercido durante a instrução processual, ele existe fora e antes do processo, e seu exercício não necessariamente será seguido do último, e este ponto é que merece ser destacado.

Usualmente, o direito à investigação, e o direito à prova em geral, é relacionado à idéia de julgamento, de formação do convencimento judicial. Ao longo deste trabalho mesmo, em diversas oportunidades foram colacionadas definições e tecidas diversas considerações ligando os direitos à prova e à investigação ao processo e às decisões judiciais.

No entanto, é exatamente tal vinculação necessária que se quer tentar combater: o exercício do direito à investigação, como desdobramento do direito à prova, pode gerar efeitos para o processo e para o convencimento judicial, mas não necessariamente, porque, antes de tudo, tal direito destina-se às partes, à acusação, à defesa e à vítima ${ }^{181}$.

Antes de iniciado o processo, ao titular da ação penal, seja ela pública ou privada, incumbe pesquisar fontes de prova para formar sua opinião acerca do cabimento ou não da propositura de ação penal, e ao imputado interessa colher material probatório no intuito de demonstrar a inviabilidade da instauração do processo penal.

\footnotetext{
${ }^{181}$ RUBÉN A. CHAIA, por exemplo, defende que as provas não servem apenas ao juiz, mas também às partes e à sociedade. No entanto, o autor deixa transparecer seu entendimento no sentido de que as provas estão intrinsecamente ligadas ao processo e à decisão judicial. Eis o que sustenta o jurista: "la prueba no sólo sirve al juez que la utiliza al exponer sus argumentos, sino que también há de servir a las partes para confrontar sus hipótesis y controlar la decisión judicial o impugnarla mediante los recursos que estimen pertinentes" (...) "pero la prueba no resulta necesaria solo para los sujetos involucrados en el proceso, es vital también para la sociedad que respetará mucho más las decisiones que se adopten desde los órganos judiciales, en tanto y en cuanto éstas puedan pasar airosas por los filtros de control de la irracionalidad". Cf. La prueba en el proceso penal, Buenos Aires, Hammurabi, 2010, p. 54.
} 
Ou seja, ainda que dos direitos de ação e de defesa é que se origine o direito à prova, e que do último decorra o direito à investigação ${ }^{182}$, não necessariamente este deverá ser exercido com escopo processual. Ao exercício do direito de investigação pode ou não se seguir um processo, já que uma das finalidades desse exercício em fase anterior ao processo penal é justamente impedir a formulação de acusações equivocadas e processos penais sem fundamento.

Logo, também é possível afirmar que o direito à investigação visa, num primeiro momento, à formação do convencimento das partes, dos interessados na demanda que eventualmente será proposta. O órgão da acusação deve ser persuadido da necessidade e viabilidade de ajuizar uma ação penal contra o imputado, e este, na qualidade de possível réu em futura demanda, tem interesse em buscar fontes, pessoas ou coisas capazes de demonstrar o equívoco de eventual instauração de um processo.

Apenas se ajuizada a ação penal é que o direito à investigação repercutirá também na formação do convencimento judicial, pois das fontes de prova colhidas é que serão produzidos os meios de prova, cujos elementos servirão à formação da convicção do juiz.

Ou seja, embora a noção de direito à prova, e em especial de direito à investigação, esteja fortemente atrelada à idéia de processo, de julgamento, de formação do convencimento judicial, mostra-se fundamental desfazer este mito de vinculação necessária entre direito à investigação e ação penal. $\mathrm{O}$ direito à investigação pode sim ser exercido independentemente da existência de processo, dada sua autonomia.

Em recente trabalho sobre o tema, o jurista FLÁVIO LUIZ YARSHELL analisou o direito autônomo à prova no campo civil. Conclusões semelhantes às ora aqui apontadas foram alcançadas pelo autor e, dada sua relevância para o presente estudo, merecem ser aqui transcritas: "se o assim denominado direito à prova, visto como desdobramento da ação e da defesa, pode abranger as prerrogativas de buscar e obter a prova, essas mesmas prerrogativas não estão necessariamente vinculadas à declaração do direito dirigida a uma dada relação de direito material. Visto sob o prisma da busca e da obtenção das fontes de prova, o assim denominado direito à prova pode ser entendido, em

${ }^{182}$ Cf. PAOLO TONINI, Direito de defesa e prova cientifica: novas tendências do processo penal italiano in Revista Brasileira de Ciências Criminais, ano 12, no 48, maio-junho de 2004, p. 201. 
alguma medida, como antecedente do pleito de tal declaração ou, a depender do que resulte dessa busca, até mesmo como excludente do referido pleito",183.

Algumas idéias defendidas por FLÁVIO LUIZ YARSHELL em seu estudo sobre o direto autônomo à prova amoldam-se perfeitamente também ao processo penal, a exemplo das acima expostas. Outras, no entanto, devem ter sua aplicação restrita ao campo civil.

O autor sustenta, por exemplo, que investigar, buscar a fonte de prova, é também produzir prova de forma antecipada, pois da atividade investigatória resultam autênticos elementos de prova, cujo conhecimento não pode ser descartado. Afirma o autor que, "quando se investiga (ainda que mediante surpresa) e se registra o resultado da investigação, não se está apenas obtendo ou conservando uma fonte de prova. (...) Salvo em casos nos quais rigorosamente se busca apenas preservar fisicamente a fonte, nos demais, chegar à fonte é também empregar o meio de prova. Por outras palavras, buscar a fonte, no mais das vezes, é também produzir prova, ainda que não se esteja, aí, pensando diretamente na formação do convencimento do juiz que aplicará o direito no caso concreto, mas sim nos sujeitos parciais ${ }^{, 184}$.

Ainda que as conclusões acima possam ser aplicadas ao processo civil, no processo penal, devido às suas peculiaridades, as assertivas não se coadunam perfeitamente. Isto porque, na seara criminal, os atos investigatórios são realizados, no mais das vezes, de forma unilateral, sem observância ao contraditório. O chamado fator surpresa, aliás, geralmente é decisivo para o êxito das investigações ${ }^{185}$. A comunicação prévia à parte contrária dos atos investigatórios a serem realizados possivelmente frustraria os objetivos da investigação, salvo em relação a meios de investigação de prova específicos, como a quebra de sigilo bancário ou fiscal ${ }^{186}$.

Considerando, pois, que a maioria das diligências realizadas no curso da instrução preliminar ocorre sem a garantia do contraditório, impossível falar-se que, na investigação penal, ao buscar-se fontes de prova também se está a empregar o meio de

\footnotetext{
${ }^{183} \mathrm{Cf}$. Antecipação da prova sem o requisito da urgência e direito autônomo à prova, São Paulo, Malheiros, 2009, p. 210.

${ }^{184}$ Cf. Antecipação da prova sem o requisito da urgência e direito autônomo à prova, São Paulo, Malheiros, 2009, p. 212.

${ }^{185}$ Nesse sentido, observa DELFINO SIRACUSANO que os meios de investigação de provas são baseados no fator surpresa. Cf. Manuale di diritto processuale penale, vol. 1, Milano, Giuffrè, 1990, p. 404.

${ }^{186} \mathrm{Na}$ busca e apreensão e na interceptação telefônica, por exemplo, o fator surpresa é essencial à efetividade das medidas.
} 
prova, que fornecerá os elementos de informação, os dados objetivos que o juiz tomará em conta para proferir a decisão ${ }^{187}$.

Na verdade, FLÁVIO LUIZ YARSHELL reconhece que a atividade de investigação no campo civil não guarda exata correspondência com a realizada no campo penal, já que as técnicas empregadas são diversas, assim como os agentes responsáveis por sua promoção ${ }^{188}$. Admite ainda o jurista que as informações obtidas unilateralmente através das investigações não podem, por si sós, fundamentar decisões judiciais no campo criminal $^{189}$.

Logo, as relevantes conclusões a que chegou FLÀVIO LUIZ YARSHELL em relação ao direito à prova no âmbito processual civil devem ser empregadas com ressalvas em matéria criminal ${ }^{190}$. Imperioso ainda ressaltar que os próprios conceitos utilizados pelo autor de meios de prova, elementos de prova e fontes de prova não são equivalentes aos referidos logo no primeiro capítulo deste estudo, tanto que o autor admite a utilização de meios de prova antes e fora do processo, capazes de fornecer verdadeiros elementos de prova, os quais podem servir à formação da convicção dos interessados ou do juiz $^{191}$.

$\mathrm{Na}$ seara criminal, em que, via de regra, existe uma fase anterior à instauração do processo penal propriamente dito, as definições trazidas logo no início deste trabalho acerca das expressões fontes de prova, meios de prova e meios de investigação de prova parecem mais adequadas e aptas a evitar certas distorções indesejáveis.

Além disso, não se pode olvidar que o processo criminal possui características peculiares que o distinguem sobremaneira do processo civil, não apenas as já referidas, no sentido de que as investigações devem contar com elementos-surpresa para não verem frustrados seus objetivos, ou então de que os agentes que realizam as

187 No mesmo sentido, afirma MIRJAN R. DAMASKA que "a atividade investigativa conduz mais frequentemente a informações úteis para a aquisição da prova do que para a prova entendida em sentido estrito". Cf. I volti della giustizia e del potere - Analisi comparatistica del processo, Bologna, Il Mulino, 1991, p. 113. Em vernáculo: "L'attività investigativa conduce tuttora più spesso ad informazioni utili per l'aquisizione delle prove che alle prove intese in senso stretto".

${ }^{188} \mathrm{Cf}$. Antecipação da prova sem o requisito da urgência e direito autônomo à prova, São Paulo, Malheiros, 2009 , p. 37.

${ }^{189}$ Cf. Antecipação da prova sem o requisito da urgência e direito autônomo à prova, São Paulo, Malheiros, 2009 , p. 39.

${ }^{190}$ Sobre as semelhanças e diferenças entre o processo civil e criminal no que diz respeito à prova, veja-se KARL JOSEPH ANTON MITTERMAIER, Tratado de la prueba en materia criminal, trad. Primitivo González del Alba, Buenos Aires, Hammurabi, 2006, pp. 71-73.

${ }^{191}$ Veja-se, a respeito, FLÁVIO LUIZ YARSHELL, Antecipação da prova sem o requisito da urgência e direito autônomo à prova, São Paulo, Malheiros, 2009, pp. 34-35 e 212. 
investigações penais são diversos, a exemplo da polícia: no processo penal, deve-se sempre ter em mente que, de um lado, figura o Estado que, com todo seu aparato repressor, objetiva perseguir e punir aqueles que cometem crimes e, de outro, figuram os acusados, cidadãos comuns que partem de uma posição desfavorável, justamente porque contra eles já pesa uma acusação.

É justamente com a finalidade de compensar a posição desprivilegiada que o acusado assume desde o início do processo, e permitir que as partes desfrutem de uma igualdade efetiva, que aos réus são assegurados certos direitos e prerrogativas não conferidas à parte contrária ${ }^{192}$, a exemplo de prazos mais dilatados, repartição diferenciada do ônus da prova, entre outros ${ }^{193}$.

Pelas razões expostas é que se deve entender que, no exercício do direito à investigação no âmbito criminal, e em momento anterior ao processo, as partes, ainda que potenciais, utilizam, via de regra, meios de investigação ou de pesquisa de prova, através dos quais colhem apenas fontes de prova, aqui entendidas como as pessoas e coisas das quais se pode obter a prova em eventual processo penal. Os meios de prova, salvo em hipóteses excepcionais (que serão oportunamente objeto de análise), são produzidos no curso do processo, com a necessária observância do contraditório.

A propósito, é justamente em virtude de os atos investigatórios penais serem realizados unilateralmente que as informações através deles obtidas não podem servir como elementos de prova aptos a fundamentar as decisões finais.

A importância das discussões acerca da inexistência de contraditório na instrução preliminar, e dos possíveis usos das informações obtidas no exercício do direito à investigação, pela sua importância, merecem ser objeto de estudo em separado.

\footnotetext{
${ }^{192}$ Como bem observa ANTONIO SCARANCE FERNANDES, os princípios da igualdade e do contraditório exigem que as normas procedimentais assegurem às partes tratamento isonômico. Disso decorre o princípio do favor rei, segundo o qual, "para equilibrar a situação do acusado à posição naturalmente privilegiada do Ministério Público, órgão de Estado, permite regras que o favoreçam”. Cf. Teoria geral do procedimento e o procedimento no processo penal, São Paulo, Revista dos Tribunais, 2005, p. 45.

193 Cf. ANTONIO MAGALHÃES GOMES FILHO, A motivação das decisões penais, São Paulo, Revista dos Tribunais, 2001, p. 43. Complementa o autor que "longe de configurar uma violação da igualdade entre as partes, o tratamento privilegiado de quem se defende atende não apenas a um princípio geral, que impõe maior consideração à posição daquele que poderá vir a ter sacrificado o seu direito à liberdade, mas igualmente resulta da constatação histórica de que na generalidade dos casos a acusação criminal recai sobre sujeitos já desfavorecidos no plano social e econômico".
} 


\subsection{UTILIZAÇÃO DAS INFORMAÇÕES OBTIDAS NO EXERCÍCIO DO DIREITO À INVESTIGAÇÃO}

Como visto anteriormente, às possíveis partes de um processo penal deve ser assegurado o direito à investigação, ou seja, o direito de pesquisar, de buscar material apto a fornecer informações relevantes sobre os fatos alegados, como própria decorrência do direito à prova.

E o direito deve ser assegurado durante toda a persecução penal, tanto em sua fase judicial, iniciada após a propositura da ação penal, como antes do processo, até para o fim de evitá-lo. Isto significa que o direito à investigação é um direito autônomo, embora relacionado ao processo, não necessariamente será por ele seguido.

Importante ainda mencionar que o direito à investigação tem não apenas como titulares mas também como destinatários as partes, ainda que potenciais, já que a descoberta de informações relevantes sobre o ilícito penal serve, num primeiro momento, à sua orientação ${ }^{194}$, à formação de seu posicionamento no que diz respeito à causa: dependendo dos dados objetivos colhidos no exercício do direito à investigação, o órgão da acusação pode até deixar de oferecer a ação penal.

Logo, é possível afirmar que, quando o direito à investigação é exercido em momento anterior à instauração do processo, as possíveis partes não produzem prova em sentido estrito, no máximo obtêm fontes de prova que poderão ser levadas à apreciação judicial através de sua introdução no processo pelos meios de prova ${ }^{195}$.

Como bem asseveram ANTONIO MAGALHÃES GOMES FILHO e GUSTAVO HENRIQUE IVAHY BADARÓ, “os elementos trazidos pela investigação não constituem, a rigor, provas no sentido técnico-processual do termo, mas informações de caráter provisório, aptas somente a subsidiar a formulação de uma acusação perante o juiz ou, ainda, servir de fundamento para admissão dessa acusação e, eventualmente, para a decretação de alguma medida de natureza cautelar ",196.

\footnotetext{
${ }^{194}$ Cf. FLÁVIO LUIZ YARSHELL, Antecipação da prova sem o requisito da urgência e direito autônomo à prova, São Paulo, Malheiros, 2009, p. 217. Observa o autor que o Estado permite que o interessado pesquise fatos e busque a prova "para que as partes possam avaliar suas chances, de sorte a ingressar em juizo com maior segurança e responsabilidade ou, por outra, simplesmente não ingressar (ou não resistir a dada pretensão)".

${ }^{195}$ Cf. GUSTAVO HENRIQUE IVAHY BADARÓ, Ônus da prova no processo penal, São Paulo, Revista dos Tribunais, 2003, p. 166.

${ }^{196}$ Cf. Prova e sucedâneos de prova no processo penal brasileiro in Revista Brasileira de Ciências Criminais, São Paulo, Revista dos Tribunais, nº 65, março-abril de 2007, p. 193.
} 
O jurista MARCELLUS POLASTRI LIMA também chama a atenção para a freqüente confusão entre atos de prova e atos de investigação, ressaltando que, embora comumente se denominem provas em sentido amplo os dados obtidos durante a investigação, só podem receber tal qualificação os elementos colhidos em observância ao contraditório; os demais não passam de atos de investigação ${ }^{197}$.

Ou seja, via de regra, os dados obtidos no exercício do direito à investigação antes de iniciado o processo só podem ser usados até este momento, quer para que as partes formem seu convencimento e tracem suas respectivas estratégias de atuação, quer para que o magistrado aceite a ação penal proposta ou mesmo para ele que fundamente eventual decisão proferida nessa etapa da persecução. Nesse sentido, observa AURY LOPES JR. que "os atos praticados na instrução preliminar esgotam sua eficácia probatória com a admissão da acusação, isto é, servem para justificar medidas cautelares e outras restrições adotadas no curso da fase pré-processual e para justificar o processo ou o não-processo ${ }^{, 198}$.

Desse modo, é possível concluir que as informações obtidas no exercício do direito à investigação (na fase pré-processual da persecução) podem ser utilizadas para orientar as partes, quer quanto à viabilidade da ação penal, quer quanto às suas chances em juízo, ou mesmo para fins de definição de estratégias da acusação e da defesa. Também servirão tais dados como fontes de prova em eventual processo, pois, com base nos mesmos, as partes poderão requerer ao juízo os meios de prova que desejarão ver realizados.

Os conhecimentos adquiridos através dos atos investigatórios também podem subsidiar as decisões judiciais proferidas nesta fase inicial da persecução penal, tanto as de natureza cautelar como a decisão que aceita ou rejeita a ação penal proposta.

Estas são, portanto, as principais destinações das informações obtidas no exercício do direito à investigação, ou, ao menos, deveriam ser, uma vez que o art. 155 do Código de Processo Penal permite, em sua atual redação ${ }^{199}$, que os elementos de informação colhidos no inquérito policial sejam valorados pelo magistrado no momento de

${ }^{197}$ Cf. A prova penal de acordo com a reforma processual penal, $3^{\text {a }}$ ed., Rio de Janeiro, Lumen Juris, 2009, p. 14.

${ }^{198}$ Cf. Sistemas de investigação preliminar no processo penal, Rio de Janeiro, Lumen Juris, 2001, p. 119.

${ }^{199}$ Eis o caput do dispositivo legal mencionado: "O juiz formará sua convicção pela livre apreciação da prova produzida em contraditório judicial, não podendo fundamentar sua decisão exclusivamente nos elementos informativos colhidos na investigação, ressalvadas as provas cautelares, não repetíveis e antecipadas". 
proferir a sentença, apenas com a ressalva de que a convicção do juiz não pode se embasar exclusivamente no inquérito policial.

Ao comentar o aludido dispositivo, ANTONIO MAGALHÃES GOMES FILHO observou que "para chegar ao resultado da prova, ou seja, à conclusão sobre a veracidade ou a falsidade de um fato afirmado, o juiz penal pode servir-se tanto de elementos de prova (produzida em contraditório) como de informações trazidas pela investigação. Só não poderá se utilizar, diz a lei, exclusivamente de dados informativos da investigação, ${ }^{, 200}$.

$\mathrm{Na}$ verdade, como bem lembrou CLEUNICE VALENTIM BASTOS PITOMBO, o artigo 155 do Código de Processo Penal foi alterado recentemente pela Lei $\mathrm{n}^{\mathrm{o}}$ 11.690/08, que, na última grande reforma processual, modificou diversas disposições do diploma relativas à prova. Pois bem, o projeto de lei originário (PL 4.205/2001) pretendia excluir das razões de decidir os elementos informativos obtidos no inquérito policial, exceção feita às provas cautelares e irrepetíveis. Todavia, o texto legal sofreu modificações em sua tramitação no Congresso, e de sua versão final passou a fazer parte o vocábulo “exclusivamente", que não constava da redação inicial do projeto de lei. Nas palavras da autora, "tal inclusão acabou por limitar o instituto",201.

Mesmo diante de aludida previsão legal, sustenta-se que a sentença não deveria apoiar-se sequer complementar ou subsidiariamente em elementos colhidos no inquérito policial sem a observância das garantias do contraditório e da ampla defesa.

AURY LOPES JR. acredita ser “absolutamente inconcebivel que os atos praticados por uma autoridade administrativa, sem a intervenção do órgão jurisdicional, tenham valor probatório na sentença. Não só não foram praticados ante o juiz, senão que simbolizam a inquisição do acusador, pois o contraditório é meramente aparente e muitas vezes inexistente. Da mesma forma, a igualdade sequer é um ideal pretendido, muito pelo contrário, de todas as formas se busca acentuar a vantagem do acusador público"202.

Mesmo antes da entrada em vigor da Lei $n^{\circ} 11.690 / 08$, ANTONIO SCARANCE FERNANDES já ponderava que "nunca se conseguiu afastar inteiramente a

${ }^{200}$ Cf. Provas - Lei 11.690, de 09.06.2008 in As reformas no processo penal - as novas leis de 2008 e os projetos de reforma, coord. Maria Thereza Rocha de Assis Moura, São Paulo, Revista dos Tribunais, 2008, p. 251.

${ }^{201}$ Cf. Considerações iniciais sobre a Lei 11.690/08 in Boletim do Instituto Brasileiro de Ciências Criminais, $\mathrm{n}^{\mathrm{o}}$ 188, ano 16, Edição Especial, julho de 2008, p. 20.

${ }^{202}$ Cf. Sistemas de investigação preliminar no processo penal, Rio de Janeiro, Lumen Juris, 2001, pp. 188189. 
influência dos elementos informativos obtidos durante a investigação pela polícia, pelo juiz instrutor ou promotor, sobre o julgamento, pois, em virtude de serem colhidos próximos do fato, têm maior poder de convencimento a respeito da realidade dos acontecimentos. Até hoje é comum sustentar-se o aproveitamento desses elementos com base no princípio da verdade real. Parte-se, às vezes, da premissa de que incumbe ao acusado desmentir os informes obtidos na investigação, os quais, se confirmados ou não contrariados em juízo, merecem ser utilizados. Há, com justiça, forte resistência a essas idéias, pois com elas se negam os princípios do contraditório, da ampla defesa e da presunção de inocência ${ }^{203, " . ~}$

A possibilidade de utilização de tais informes colhidos na instrução preliminar como provas a serem valoradas pelo juiz na formação de seu convencimento. deve ser veementemente refutada (salvo exceções que serão adiante analisadas), por inúmeras razões, sendo talvez a principal delas o fato de que os atos investigatórios são, em geral, realizados unilateralmente, sem a observância do contraditório.

O contraditório é uma garantia do próprio devido processo legal, e faz-se imprescindível para a atividade instrutória ${ }^{204}$. Na lição de LUIGI FERRAJOLI, “ainda mais importante do que a necessidade da prova é a garantia do contraditório, isto é, a possibilidade da refutação ou da contraprova, ${ }^{205}$.

O contraditório, entendido como ciência bilateral dos atos e termos do processo, com a possibilidade de impugná-los, assegura ainda o direito de defesa, pois permite ao imputado ter conhecimento dos atos processuais e contrariá-los ${ }^{206}$.

203 Cf. Teoria Geral do Procedimento e o Procedimento no Processo Penal, São Paulo, Revista dos Tribunais, 2005, p. 90.

204 Cf. ADA PELLEGRINI GRINOVER, O processo constitucional em marcha, São Paulo, Max Limonad, 1985, p. 09 e 17.

${ }^{205}$ Cf. Direito e razão - Teoria do garantismo penal, São Paulo, Revista dos Tribunais, 2002, p. 121.

${ }^{206}$ È possível afirmar que o contraditório assegura o direito à defesa, mas também é pelo último garantido. Como explicam ADA PELLEGRINI GRINOVER, ANTONIO SCARANCE FERNANDES e ANTONIO MAGALHÃES GOMES FILHO, "defesa e contraditório estão indissoluvelmente ligados, porquanto é do contraditório (visto em seu primeiro momento, da informação) que brota o exercício da defesa; mas é essa como poder correlato ao de ação - que garante o contraditório. A defesa, assim, garante o contraditório, mas também por este se manifesta e é garantida”. Cf. As nulidades no processo penal, $11^{\text {a }}$ ed., São Paulo, Revista dos Tribunais, 2009, p. 69.

Oportuno mencionar o posicionamento de MARTA SAAD, para quem a defesa pode existir independentemente do contraditório. A autora sustenta tal tese com base no fato de que, embora no inquérito policial brasileiro não exista contraditório, o direito à defesa pode ser exercido. Cf. $O$ direito de defesa no inquérito policial, São Paulo, Revista dos Tribunais, 2004, p. 223.

De fato, parece ilógico afirmar que defesa e contraditório são indissociáveis, e ao mesmo tempo sustentar que na fase de investigações criminais não há contraditório, mas apenas exercício do direito de defesa. Quem melhor desfaz a aparente contradição é ANTONIO SCARANCE FERNANDES, ao esclarecer que, mesmo 
Logo, no que se relaciona à atividade probatória, o contraditório assegura tanto o direito à realização de provas para demonstração da veracidade das alegações formuladas como a produção de provas que evidenciem a incorreção das asserções da parte contrária.

Para que determinada prova possa ser apreciada e valorada pelo juiz, servindo à formação de seu convencimento, é necessário que sobre ela tenha sido exercido o contraditório, ou seja, a prova deve ter sido objeto de conhecimento por ambas as partes, e a estas deve ter sido assegurada a possibilidade de impugná-la, ou mesmo de produzir outras provas que a infirmassem.

Não se pode olvidar também que o contraditório, além de assegurar os direitos de ação e defesa, também representa a melhor forma de reconstrução dos fatos, já que o método dialético é tido como dos mais eficazes para a verificação da veracidade das alegações formuladas pelas partes ${ }^{207}$.

Considerando, assim, que os atos de investigação são realizados, via de regra, unilateralmente, sem o conhecimento ou a participação do outro sujeito processual e, por conseguinte, sem a observância do contraditório, impossível cogitar-se de sua eficácia probatória, isto é, de sua utilização como prova em sentido estrito para fins de decisão judicial.

$\mathrm{Na}$ verdade, não é pacífica na doutrina a idéia de inexistência de contraditório na fase de investigação criminal. ROGÉRIO LAURIA TUCCI, por exemplo, defende com veemência ser indispensável a instalação de um regime de contraditoriedade já na fase de investigação criminal, pois este seria um direito fundamental do imputado, assim como a plenitude de defesa também na fase inicial da persecução penal ${ }^{208}$.

JOAQUIM CANUTO MENDES DE ALMEIDA também sustentava a idéia de contrariedade na instrução prévia, principalmente no que dizia respeito à antecipação

\footnotetext{
não havendo contraditório na investigação, existe direito de defesa, só que esta não é ampla, tal como prevista na Constituição Federal. A defesa assegurada na etapa investigatória é limitada ao resguardo dos interesses mais relevantes do imputado, e seu exercício permite, nesse escopo, "o requerimento de diligências, o pedido de liberdade provisória, de relaxamento do flagrante, a impetração de habeas corpus". Cf. Processo penal constitucional, $5^{\text {a }}$ ed., São Paulo, Revista dos Tribunais, 2007, p. 70.

${ }^{207}$ Cf. GIULIO UBERTIS, Il contradittorio nella formazione della prova penale in Estudos em homenagem à Professora Ada Pellegrini Grinover, org. Flávio Luiz Yarshell e Maurício Zanóide de Moraes, São Paulo, DPJ, 2005, p. 332.

${ }^{208}$ Cf. Investigação criminal no projeto de reforma do Código de Processo Penal in Revista do Advogado, $\mathrm{n}^{\mathrm{o}}$ 78, ano XXIV, setembro de 2004, p. 108.
} 
das $\operatorname{provas}^{209}$. Atualmente, AURY LOPES JR., mesmo reconhecendo a impossibilidade de um contraditório pleno na investigação preliminar, defende a existência de um contraditório mínimo, com a comunicação e participação dos sujeitos em determinados $\operatorname{atos}^{210}$.

Observa ainda FAUZI HASSAN CHOUKR que os fautores da existência de contraditório na investigação criminal fundamentam sua opinião principalmente no fato de que tal fase seria um verdadeiro processo administrativo preparatório ao exercício da ação penal, e também no conflito de interesses verificado já nesta etapa da persecução, a permitir que se fale em litígio e acusado ${ }^{211}$.

Respeitado o posicionamento em contrário, parece que o entendimento mais acertado é aquele segundo o qual inexiste contraditório real e efetivo na fase de investigação criminal.

Como já afirmado, os sujeitos exercem seu direito à investigação de modo unilateral, geralmente sem que a parte contrária tenha sequer conhecimento dos atos a serem realizados, o que serve até para que os objetivos da atividade não restem frustrados. O chamado elemento-surpresa muitas vezes é determinante para o sucesso da investigação empreendida $^{212}$, de modo que assegurar o contraditório pleno na instrução preliminar vai contra os próprios objetivos desta ${ }^{213}$.

Sobre este ponto, muito pertinentes são as observações de ANTONIO SCARANCE FERNANDES, para quem "não há razão para se estender à investigação um contraditório amplo e irrestrito, reservado ao estágio processual. Ainda não há procedimento, mas atos de investigação, alguns marcados pela necessidade de sigilo, como a busca e apreensão, a interceptação telefônica. Para que configure o contraditório pleno, seria necessária a ciência prévia do ato a ser realizado, a oportunidade de

209 Cf. Principios fundamentais do processo penal, São Paulo, Revista dos Tribunais, 1973, p. 114 e seguintes.

${ }_{210}$ Cf. Sistemas de investigação preliminar no processo penal, Rio de Janeiro, Lumen Juris, 2001, p. 251. Em outra obra, o autor sustenta que, quando se refere ao contraditório na fase pré-processual, alude ao seu primeiro momento, qual seja o da informação, "porque, em sentido estrito, não pode existir contraditório no inquérito porque não existe uma relação jurídico-processual, não está presente a estrutura dialética que caracteriza o processo. Não havendo o exercício de uma pretensão acusatória, não pode existir a resistência”. Cf. Introdução crítica ao processo penal (fundamentos da instrumentalidade garantista), $4^{\mathrm{a}}$ ed., Rio de Janeiro, Lumen Juris, 2006, pp. 251-252.

${ }^{211}$ Cf. Garantias constitucionais na investigação criminal, $2^{\mathrm{a}}$ ed., Rio de Janeiro, Lumen Juris, 2001, pp. 126-127.

212 Cf. GIOVANNI CONSO e VITTORIO GREVI, Compendio di procedura penale: appendice di aggiornamento, Padova, CEDAM, 2001, p. 282.

${ }^{213}$ Cf. FLÁVIO LUIZ YARSHELL, Antecipação da prova sem o requisito da urgência e direito autônomo à prova, São Paulo, Malheiros, 2009, pp. 37-39. 
participação e de reação, o que é inviável, porque o sucesso de certas diligências está exatamente na surpresa de sua realização, 214.

Também não se pode desconsiderar o fato de que a atividade investigatória realizada pelos sujeitos não é imparcial, ação e defesa buscam elementos que demonstrem a correção de suas respectivas alegações e o equívoco das asserções da parte contrária, de modo que a reconstrução dos fatos dá-se exclusivamente sob um ponto de vista parcial e unilateral $^{215}$. Lembre-se que no exercício do direito à prova - e, por conseguinte, do direito à investigação - as partes não necessariamente desejam que a verdade dos fatos venha à tona, e orientam sua atividade instrutória nesse sentido, o que é até natural, mas encontra como contrapeso na fase processual da persecução penal a atuação do juiz, a quem incumbe zelar pela dimensão epistemológica do processo ${ }^{216}$.

Não é por outra razão que tanto a presença das partes é considerada condição indispensável à garantia do contraditório em matéria probatória ${ }^{217}$ como a presença do magistrado ${ }^{218}$, pois só podem ser consideradas válidas as provas produzidas perante o juiz competente ${ }^{219}$. E a presença do magistrado é requisito imprescindível à caracterização do contraditório em relação à prova também porque uma das mais relevantes finalidades de assegurar a ciência e a possibilidade de reação inerentes à garantia é influenciar o convencimento do magistrado. Como bem observa FAUZI HASSAN CHOUKR, o binômio ciência/participação não é um fim em si mesmo, somente tem sentido enquanto pode "servir para influenciar o espirito de quem decide, produzindo provas, argumentando ou rebatendo argumentos ${ }^{, 220}$.

Desse modo, o fato de o exercício do direito à investigação antes do processo se dar de modo unilateral, sem que o outro sujeito tenha ciência prévia dos atos a serem realizados ou possa deles participar, e também sem a presença do magistrado,

${ }^{214}$ Cf. Reação defensiva à imputação, São Paulo, Revista dos Tribunais, 2002, pp. 120-122.

215 Cf. GUSTAVO HENRIQUE IVAHY BADARÓ, Ônus da prova no processo penal, São Paulo, Revista dos Tribunais, 2003, p. 222.

${ }^{216}$ Cf. MICHELLE TARUFFO, Simplesmente la verdad - El juez y la construcción de los hechos, trad. Daniela Accatino Scagliotti, Madrid, Marcial Pons, 2010, pp. 194-196. Veja-se mais sobre o assunto no item 1.3.2.

${ }^{217}$ Cf. ADA PELLEGRINI GRINOVER, O conteúdo da garantia do contraditório in Novas tendências do direito processual, Rio de Janeiro, Forense Universitária, 1990, p. 24.

${ }^{218}$ Cf. LUIGI FERRAJOLI, Direito e razão - Teoria do garantismo penal, São Paulo, Revista dos Tribunais, 2002, p. 590.

219 Cf. ADA PELLEGRINI GRINOVER, ANTONIO SCARANCE FERNANDES e ANTONIO MAGALHÃES GOMES FILHO, As nulidades no processo penal, $11^{\mathrm{a}}$ ed., São Paulo, Revista dos Tribunais, 2009 , p. 115.

${ }^{220}$ Cf. Garantias constitucionais na investigação criminal, $2^{\mathrm{a}}$ ed., Rio de Janeiro, Lumen Juris, 2001, p. 131. 
impede que se conclua pela existência de contraditório nessa etapa inicial da persecução penal.

Todavia, se praticamente não há dúvidas da imprescindibilidade do contraditório para que se possa falar em provas propriamente ditas, grandes questionamentos pairam sobre os momentos em que se deve assegurar a garantia. Discutese muito se o contraditório deve se fazer presente desde a produção da prova ou pode se dar em momento posterior.

Na doutrina estrangeira, questiona-se, por exemplo, se o contraditório deve ser para a prova ou sobre a prova, isto é, se a garantia deve ser assegurada já no momento de sua produção, ou pode se dar depois de já formada a prova ${ }^{221}$.

A distinção entre as hipóteses mencionadas é grande, já que o contraditório para a prova exige a atuação das partes na sua própria formação, enquanto no contraditório sobre a prova, embora esta possa ter sido produzida unilateralmente, a participação da parte contrária em momento posterior permite o reconhecimento do contraditório.

Para MICHELLE TARUFFO, por exemplo, o contraditório para a prova, ou seja, na formação da prova, só deve ser exigido para as provas que se formam realmente dentro do processo, depois que este já foi instaurado. Para os atos instrutórios realizados fora ou antes de processo, a mera garantia do contraditório antes da valoração da prova pelo juiz é suficiente. Nas palavras do próprio jurista, "o princípio do contraditório não pode ser uma modalidade necessária de formação da prova (exceto para as provas que se formam no processo), mas deve ser implementado quando as provas são controladas (se isto se realiza no âmbito do processo) ou, ao menos, quando são usadas no processo para a determinação dos fatos. Isto implica que se coloque as partes em condições de influir na valoração das provas que se realizará pelo juiz, é dizer, de intervir, discutir e eventualmente deduzir outras provas, antes que a decisão sobre o fato seja formulada"222.

${ }^{221}$ Cf. GIULIO UBERTIS, Il contradittorio nella formazione della prova penale in Estudos em homenagem à Professora Ada Pellegrini Grinover, org. Flávio Luiz Yarshell e Maurício Zanóide de Moraes, São Paulo, DPJ, 2005, p. 334, e SERGIO LORUSSO, Provvedimenti “allo stato degli atti” e processo penale di parti, Milano, Giuffrè Editore, 1995, p. 218.

${ }^{222}$ Cf. La prueba de los hechos, Madrid, Ed. Trotta, 2002, pp. 384-385. Eis a versão em espanhol do trecho mencionado: "el principio del contradictorio no puede ser una modalidad necesaria de formación de la prueba (excepto para las pruebas que se forman en el proceso), pero debe ser implementado cuando las pruebas son controladas (si esto se realiza en el ámbito del proceso) o, al menos, cuando se usan en el proceso para la determinación de los hechos. Esto implica que se ponga em todo caso las partes en condiciones de influir en la valoración de las pruebas que se realizará por el juez, es decir, de intervenir, discutir y eventualmente deducir otras pruebas, antes que la decisión sobre el hecho sea formulada". 
Segundo GIULIO UBERTIS, a Corte Européia de Direitos Humanos exige, como requisito mínimo, o contraditório diferido sobre a fonte de prova. Ou seja, não é imprescindível o contraditório no momento da produção da prova, mas ele deve existir ao menos posteriormente. No entanto, observou o jurista que, na doutrina italiana, o posicionamento majoritário é no sentido de que o contraditório sobre a prova é insuficiente, a garantia deve se fazer presente já no momento da produção. Porém, não se entende ser essencial assegurar o contraditório para a prova em relação a decisões diversas daquelas de absolvição ou condenação ${ }^{223}$.

A propósito, GIULIO UBERTIS faz menção ainda a situações em que o contraditório não é exigido nem para a prova nem sobre a prova (contraditório diferido). Seriam as hipóteses de contraditório implícito (em que o imputado renuncia à garantia, concordando com o uso da prova produzida unilateralmente pela parte contrária), impossível (em que o ato instrutório é, por si só, incompatível com a garantia) ou "contaminado" (por algum ato ilícito) ${ }^{224}$.

$\mathrm{Na}$ doutrina brasileira, de modo geral, também se admite o contraditório sobre a prova, ou seja, o contraditório diferido, mas apenas nas hipóteses de provas irrepetíveis, cautelares ou antecipadas ${ }^{225}$.

As expressões são tratadas muitas vezes como sinônimas pela doutrina ${ }^{226}$, reinando certo caos terminológico no uso das mesmas. Considerando, porém, que o art. 155 do Código de Processo Penal excepciona a regra de que o juiz não poderá formar sua convicção exclusivamente com base nos elementos informativos colhidos na investigação,

${ }^{223}$ Cf. Il contradittorio nella formazione della prova penale in Estudos em homenagem à Professora Ada Pellegrini Grinover, org. Flávio Luiz Yarshell e Maurício Zanóide de Moraes, São Paulo, DPJ, 2005, pp. 335-337.

${ }^{224}$ Maiores explicações sobre estas hipóteses podem ser encontradas em Il contradittorio nella formazione della prova penale in Estudos em homenagem à Professora Ada Pellegrini Grinover, org. Flávio Luiz Yarshell e Maurício Zanóide de Moraes, São Paulo, DPJ, 2005, pp. 337-340.

${ }^{225}$ Cf. ANTONIO MAGALHÃES GOMES FILHO, Provas - Lei 11.690, de 09.06.2008 in As reformas no processo penal - as novas leis de 2008 e os projetos de reforma, coord. Maria Thereza Rocha de Assis Moura, São Paulo, Revista dos Tribunais, 2008, p. 255.

${ }^{226}$ A jurista ADA PELLEGRINI GRINOVER, por exemplo, menciona a existência de determinadas perícias que têm "natureza cautelar" e visam a assegurar o resultado da prova. Cf. O conteúdo da garantia do contraditório in Novas tendências do direito processual, Rio de Janeiro, Forense Universitária, 1990, p. 29. Ainda em relação ao tema, observam ADA PELLEGRINI GRINOVER, ANTONIO SCARANCE FERNANDES e ANTONIO MAGALHÃES GOMES FILHO que "existem provas - como o exame do corpo de delito e do local do crime - que têm natureza cautelar e visam a assegurar seu resultado antes da instauração do processo penal, exigindo-se sua antecipação ad perpetuam rei memoriam. Para essas cautelas, o contraditório fica diferido para momentos sucessivos". Cf. As nulidades no processo penal, $11^{\mathrm{a}}$ ed., São Paulo, Revista dos Tribunais, 2009, p. 115. O jurista GUILHERME DE SOUZA NUCCI, por sua vez, alude à produção antecipada de provas como um procedimento incidente, de natureza cautelar. Cf. Código de processo penal comentado, 9ª ed., São Paulo, Revista dos Tribunais, 2009, p. 351. 
ressalvadas as provas cautelares, não repetíveis e antecipadas, talvez fosse o caso de empreender certas distinções entre tais locuções, até para dar sentido à norma referida, uma vez que a lei não se vale de palavras desnecessárias ou inúteis (ao menos, não deveria fazêlo).

\subsubsection{Provas irrepetíveis, cautelares e antecipadas}

$\mathrm{Na}$ tentativa de empreender algumas distinções entre as expressões provas irrepetíveis, cautelares e antecipadas, referidas no art. 155 do Código de Processo Penal, é possível afirmar que a primeira delas é a que, talvez, apresente maior facilidade de conceituação. Segundo MARCELLUS POLASTRI LIMA, são provas irrepetíveis “aquelas que só podem ser produzidas no momento do seu descobrimento, devido à sua natureza, peculiar,"227.

Esclarece JOAQUIM CANUTO MENDES DE ALMEIDA que o ato instrutório promovido na fase investigativa pode não ser repetido na fase processual quer por circunstâncias fáticas, quer por circunstâncias temporais, quer por razões de conveniência. Segundo o autor, "a inadiabilidade e a intransportabilidade da produção de prova" podem se dever ao material probatório, ao instrumental probatório ou ao pessoal probatório $^{228}$.

Ou seja, provas irrepetíveis são aquelas que, uma vez colhidas, não mais poderão ser reproduzidas. MARCELLUS POLASTRI LIMA cita como exemplos determinadas perícias, pessoas que provável ou certamente não poderão ser ouvidas na fase de instrução em face de grave doença, morte ou desaparecimento ${ }^{229}$.

Considera-se, pois, que sendo o ato instrutório da investigação criminal irrepetível em Juízo, pode o mesmo adquirir caráter definitivo, passando a ser aceito como prova mesmo não tendo havido observância ao contraditório no momento de sua produção. $\mathrm{Na}$ hipótese, incide o chamado contraditório diferido, que se dá sobre a prova anteriormente produzida.

${ }^{227}$ Cf. A prova penal de acordo com a reforma processual penal, $3^{\text {a }}$ ed., Rio de Janeiro, Lumen Juris, 2009, p. 53.

${ }^{228}$ Cf. Princípios fundamentais do processo penal, São Paulo, Revista dos Tribunais, 1973, p. 23.

${ }^{229}$ Cf. A prova penal de acordo com a reforma processual penal, $3^{\mathrm{a}}$ ed., Rio de Janeiro, Lumen Juris, 2009, p. 53 . 
Pode ocorrer, no entanto, que, mesmo sendo o ato da investigação irrepetível, seja possível dar ciência prévia à parte contrária de sua realização.

Como dito anteriormente, existem atos instrutórios que, de fato, devem ser feitos unilateralmente para que sua própria finalidade não reste frustrada. No entanto, existem também determinadas diligências irrepetíveis em que a comunicação anterior de sua realização a outra parte não acarreta prejuízo algum a seus objetivos. O jurista ANTONIO SCARANCE FERNANDES cita a inquirição de uma testemunha como exemplo de ato investigatório em que a ciência prévia à parte contrária e sua conseqüente participação na diligência não acarretam qualquer prejuízo à finalidade do ato ${ }^{230}$. Em tais hipóteses, a observância do contraditório para a prova, ou seja, desde a sua produção, mostra-se imprescindível.

É possível concluir, portanto, que nos casos de irrepetibilidade do ato de instrução preliminar, sempre que possível a ciência prévia da parte contrária sobre sua realização, deve-se proceder a um incidente jurisdicionalizado para colheita da prova, a fim de que o contraditório reste assegurado desde sua formação. Isto porque o contraditório para a prova deve ser a regra, a exceção é o contraditório sobre a prova (ou diferido) ${ }^{231}$.

Note-se que a irrepetibilidade do ato também deve ser conhecida desde logo. Neste caso, o procedimento correto será colher a prova perante o juiz e na presença das possíveis partes, com a presença de um defensor dativo (se já houver sido identificado o autor do fato, este deverá ser intimado para o ato, com a garantia de representação de seu advogado). Nas hipóteses em que só depois de já instaurado o processo se constatar que determinada diligência, até então repetível em tese, tornou-se impassível de nova realização, o contraditório necessariamente será diferido ${ }^{232}$.

No ordenamento jurídico italiano, há a previsão de um incidente específico para a colheita de provas irrepetíveis em momento anterior ao da instrução probatória propriamente dita. Trata-se do chamado incidente probatório, que consistiria numa espécie

\footnotetext{
${ }^{230}$ Cf. Processo penal constitucional, $5^{\mathrm{a}}$ ed., São Paulo, Revista dos Tribunais, 2007, p. 72.

231 Cf. GUILHERME MADEIRA DEZEM, Da prova penal: tipo processual, provas típicas e atipicas, Campinas, Millenium, 2008, p. 91.

${ }^{232}$ Cf. ANTONIO MAGALHÃES GOMES FILHO, Provas - Lei 11.690, de 09.06.2008 in As reformas no processo penal - as novas leis de 2008 e os projetos de reforma, coord. Maria Thereza Rocha de Assis Moura, São Paulo, Revista dos Tribunais, 2008, pp. 254-255.
} 
de antecipação da fase do "dibattimento" (ou de debates), e que pode ocorrer já no curso da instrução preliminar, em razão da urgência na produção da prova ${ }^{233}$.

Na definição de ANDREA ANTONIO DALIA, o incidente probatório consiste no "instituto mediante o qual se procede, na presença do juiz, no curso das investigações preliminares, na audiência preliminar ou na fase dos atos anteriores à fase de debates, à assunção antecipada dos meios de prova"234.

$\mathrm{Ou}$ seja, o incidente probatório previsto no sistema processual penal italiano consiste num procedimento excepcional em que a prova é produzida antes da fase de debates, mas segundo as mesmas regras e garantias para a última estabelecidas, na hipótese de a irrepetibilidade do ato instrutório ser desde logo previsível ${ }^{235}$. É mais freqüente na etapa investigatória, mas pode se dar em outros momentos do procedimento anteriores à fase de debates ${ }^{236}$.

Necessário ainda mencionar que aludido incidente é realizado perante o juiz, na presença das partes e de seus respectivos advogados, tanto que apenas são utilizáveis as provas colhidas em incidente probatório em relação aos acusados cujos defensores participaram de sua respectiva produção ${ }^{237}$.

Lembram ainda MARZIA FERRAIOLI e ANDREA ANTONIO DALIA que o Código de Processo Penal italiano elenca os meios de prova suscetíveis de serem realizados previamente através de incidente probatório (por exemplo, a prova testemunhal) ${ }^{238}$.

No Brasil, a previsão de incidentes probatórios jurisdicionalizados é também reclamada há muito tempo pela doutrina. FAUZI HASSAN CHOUKR, por

\footnotetext{
${ }^{233}$ Cf. PAOLO TONINI, A prova no processo penal italiano, trad. Alexandra Martins e Daniela Mróz, São Paulo, Revista dos Tribunais, 2002, p. 82.

${ }^{234}$ Cf. Manuale di diritto processuale penale, $4^{\mathrm{a}}$ ed., Padova, CEDAM, 2001, p. 560. Eis o referido conceito, em vernáculo: “L'incidente probatório è l'istituto mediante il quale si procede, in presenza del giudice, nel corso delle indagini preliminari, nell'udienza preliminare o nella fase degli atti preliminari al dibattimento, all'assunzione antecipata di mezzi di prova".

${ }^{235}$ Cf. ANTONIO MAGALHÃES GOMES FILHO, Provas - Lei 11.690, de 09.06.2008 in As reformas no processo penal - as novas leis de 2008 e os projetos de reforma, coord. Maria Thereza Rocha de Assis Moura, São Paulo, Revista dos Tribunais, 2008, p. 254.

${ }^{236}$ Cf. ANDREA ANTONIO DALIA, Manuale di diritto processuale penale, $4^{\mathrm{a}}$ ed., Padova, CEDAM, 2001, p. 560.

${ }^{237}$ Cf. PAOLO TONINI, A prova no processo penal italiano, trad. Alexandra Martins e Daniela Mróz, São Paulo, Revista dos Tribunais, 2002, p. 82.

${ }^{238}$ Cf. Manuale di diritto procesuale penale, $7^{\mathrm{a}}$ ed., Padova, CEDAM, 2010, p. 528.
} 
exemplo, defende a incidentalização típica de medidas de investigação, principalmente para os atos que envolvam valores constitucionalmente consagrados, como a intimidade ${ }^{239}$.

AURY LOPES JR. também sustenta a necessidade de instauração do incidente de produção antecipada da prova para que os elementos colhidos no seio de uma investigação possam ser utilizados no julgamento. O jurista defende que ao imputado deve ser permitido participar ativamente da produção antecipada de provas e, em relação às provas periciais irrepetíveis, deve lhe ser permitido oferecer quesitos e conhecer seus $\operatorname{resultados}^{240}$. Afirma ainda o autor que "a única forma de valorar na sentença condenatória um ato do inquérito desta natureza, sem que tenha sido repetido em juízo, é através da produção antecipada, que opera como um instrumento para jurisdicionalizar e conceder-lhe o status de ato de prova". Concluiu, finalmente, que "a produção antecipada de provas tem sua eficácia condicionada aos requisitos mínimos de jurisdicionalidade, contraditório, possibilidade de defesa e fiel reprodução na fase processual ${ }^{\text {,241 }}$.

Nessa esteira, MARTA SAAD também defende que para o ato realizado no curso de instrução preliminar adquirir valor probatório, deve ter sido ofertada a possibilidade de defesa quando de sua realização na fase inicial da persecução. Tal defesa consubstanciar-se-ia na possibilidade de o investigado acompanhar a produção da prova, formular quesitos ao perito, requerer outros atos instrutórios, entre outros ${ }^{242}$.

Os juristas ADA PELLEGRINI GRINOVER, ANTONIO MAGALHÃES GOMES FILHO e ANTONIO SCARANCE FERNANDES também sustentam que, salvo as hipóteses em que não existe suspeita contra pessoa determinada, ou os casos de absoluta urgência (em que há risco de desaparecimento dos sinais do crime ou impossibilidade de conservação da coisa a ser examinada), deveria ser conferida ao imputado a oportunidade de apresentar quesitos para maior garantia de sua defesa ${ }^{243}$.

Inegável, portanto, a tendência existente na atualidade de exigir que a colheita de provas irrepetíveis em momento anterior ao da instrução probatória propriamente dita seja não só determinada por autoridade judicial, como conte com a

\footnotetext{
${ }^{239}$ Cf. Garantias constitucionais na investigação criminal, $2^{\mathrm{a}}$ ed., Rio de Janeiro, Lumen Juris, 2001, pp. 216-217.

${ }^{240} \mathrm{Cf}$. Sistemas de investigação preliminar no processo penal, Rio de Janeiro, Lumen Juris, 2001, p. 252.

${ }^{241}$ Cf. Sistemas de investigação preliminar no processo penal, Rio de Janeiro, Lumen Juris, 2001, p. 193.

${ }^{242}$ Cf. $O$ direito de defesa no inquérito policial, São Paulo, Revista dos Tribunais, 2004, p. 182.

${ }^{243}$ Cf. As nulidades no processo penal, $11^{\mathrm{a}}$ ed., São Paulo, Revista dos Tribunais, 2009, p. 145.
} 
participação das partes ${ }^{244}$, salvo nas hipóteses em que for impossível a presença do outro sujeito, quer para não frustrar o objetivo da diligência, quer porque ainda não se tem suspeito determinado, quer porque a realização do ato é tão premente que a ciência prévia do envolvido o obstaria ${ }^{245}$

Necessário mencionar que, atualmente, no Brasil, inexiste um instituto semelhante ao incidente probatório italiano, mas há vários dispositivos do Código de Processo Penal vigente que tratam da produção de provas antes da fase instrutória propriamente dita, e que remetem à distinção que ora se objetiva empreender entre provas antecipadas, cautelares e irrepetíveis.

Como visto acima, a idéia de prova irrepetível não apresenta maiores dificuldades de compreensão. Mais tormentosa se mostra a distinção entre provas cautelares e antecipadas. Aliás, não apenas no processo penal mas também no processo civil o tema é alvo de intensos debates jurídicos. Grandes processualistas civis brasileiros já se dedicaram ao estudo das diferenças/similitudes entre tutela cautelar e tutela antecipada $^{246}$.

Aqui, a discussão sobre a matéria se restringirá às provas no campo processual penal, mas antes de tratar das possíveis diferenças entre a prova cautelar e a prova antecipada, mostra-se oportuno estabelecer algumas premissas conceituais necessárias à melhor compreensão da matéria.

O processo cautelar visa a assegurar a eficácia de um outro processo, seja de conhecimento ou de execução, evitando danos causados pelo retardamento da resposta jurisdicional. A atividade cautelar é, pois, desenvolvida através de processo que recebe o mesmo nome e tem por finalidade a obtenção de um provimento acautelatório ${ }^{247}$.

Na lição de CÂNDIDO RANGEL DINAMARCO, a instrumentalidade das medidas cautelares é de segundo grau, porque elas se colocam como "instrumento a

\footnotetext{
${ }^{244}$ Cf. GUILHERME DE SOUZA NUCCI, Código de processo penal comentado, $9^{\mathrm{a}}$ ed., São Paulo, Revista dos Tribunais, 2009, p. 351.

${ }^{245}$ Cf. ANTONIO SCARANCE FERNANDES, Processo penal constitucional, $5^{\text {a }}$ ed., São Paulo, Revista dos Tribunais, 2007, pp. 70-72.

${ }^{246}$ Cf. JOSÉ ROBERTO DOS SANTOS BEDAQUE, Tutela cautelar e tutela antecipada - tutelas sumárias e tutelas de urgência - Tentativa de sistematização, 5aed., São Paulo, Malheiros, 2006, ANTONIO CLAUDIO DA COSTA MACHADO, Tutela antecipada, São Paulo, Oliveira Mendes, 1998, entre outros. ${ }^{247}$ Cf. ANTONIO CARLOS DE ARAÚJO CINTRA, ADA PELLEGRINI GRINOVER, e CÂNDIDO RANGEL DINAMARCO, Teoria geral do processo, $20^{\mathrm{a}}$ ed., São Paulo, Malheiros, 2004, p. 317.
} 
serviço do instrumento", servindo à eficiência do provimento jurisdicional principal, o que, por seu turno, serve ao direito material e à própria sociedade ${ }^{248}$.

Em matéria de prova, medidas cautelares podem ser utilizadas a fim de assegurar a eficiência de tal atividade, no entanto, dado o seu caráter excepcional, devem se sujeitar ao preenchimento dos requisitos do periculum in mora (risco de que a ação do tempo impeça ou dificulte sobremaneira que pessoas e coisas sirvam como fonte de prova ao tempo da instrução) e do fumus boni iuris (que, na hipótese, corresponderia à relevância da prova que se quer produzir previamente) ${ }^{249}$.

Por todo o exposto é que provas cautelares podem ser definidas como “aquelas provas requeridas pelas partes para assegurar o resultado útil do processo",250. São as provas colhidas ad perpetuam memoriam e que visam à conservação das fontes, a fim de que sejam preservadas para ulterior utilização no processo.

Lembra OVÍDIO A. BAPTISTA DA SILVA que, "na asseguração cautelar de provas, o que se pretende é tão somente documentar algum fato cujo desaparecimento seja provável, a fim de poder-se depois utilizá-lo como prova" ${ }^{\text {251. }}$.

Das provas cautelares se distinguiriam as provas antecipadas pois nestas haveria verdadeira produção de prova, mas em momento anterior à fase instrutória propriamente dita. Aqui não se visaria meramente à assecuração da fonte de prova, mas sim à produção do meio de prova ${ }^{252}$.

Em outras palavras, na asseguração da prova, esta não seria produzida, mas meramente conservada, preservada para futura produção na fase instrutória do processo. Já na produção antecipada ou emergencial da prova, esta seria efetivamente produzida em momento anterior ao usual no processo, sendo desnecessária sua repetição.

\footnotetext{
${ }^{248}$ Cf. A instrumentalidade do processo, $13^{\mathrm{a}}$ ed., São Paulo, Malheiros, 2008, p. 308.

${ }^{249}$ Cf. ANTONIO MAGALHÃES GOMES FILHO, Provas - Lei 11.690, de 09.06.2008 in As reformas no processo penal - as novas leis de 2008 e os projetos de reforma, coord. Maria Thereza Rocha de Assis Moura, São Paulo, Revista dos Tribunais, 2008, p. 253. Vale a pena ainda mencionar que, além dessas características do provimento cautelar, outras costumam ser apontadas pela doutrina, entre as quais a sumariedade formal e material, a temporariedade, a referibilidade e a incapacidade de gerar coisa julgada material. Cf. JOÃO GUALBERTO GARCEZ RAMOS, A tutela de urgência no processo penal brasileiro, Belo Horizonte, Del Rey, 1998, p. 257.

${ }^{250}$ Cf. MARCELLUS POLASTRI LIMA, A prova penal de acordo com a reforma processual penal, $3^{\mathrm{a}}$ ed., Rio de Janeiro, Lumen Juris, 2009, p. 53.

${ }^{251}$ Cf. Comentários ao Código de Processo Civil, vol. XI, 2ª ed., Porto Alegre, Letras Jurídicas, 1986, p. 444.

${ }^{252}$ Cf. PONTES DE MIRANDA, Comentários ao Código de Processo Civil, t. XII, Rio de Janeiro, Forense, 1973, p. 254.
} 
Com base na explicação acima referida, alguns juristas pátrios têm distinguido as provas cautelares das antecipadas no âmbito processual penal: as primeiras seriam, basicamente, aquelas colhidas em momento anterior ao processo, por meio de uma ação cautelar própria, ao passo que as segundas seriam aquelas produzidas depois de já iniciada a ação penal, mas em momento anterior ao designado para tanto ${ }^{253}$.

Reforçando esta diferenciação, observa MARCELLUS POLASTRI LIMA que a prova cautelar é aquela obtida antes de iniciada a ação penal, tanto que fica em autos apartados à espera da instauração do futuro do processo, quando será juntada, ao passo que a prova antecipada é aquela colhida depois de proposta a demanda, e por isso mesmo é juntada imediatamente aos autos ${ }^{254}$.

No mesmo sentido parece inclinar-se o jurista ANTONIO MAGALHÃES GOMES FILHO, ao asseverar que "o que o legislador pretendeu certamente sublinhar, com a variação de nomenclatura [provas cautelares e antecipadas] foi que há situações mais gerais em que os atos de formação de prova são realizados cautelarmente, independentemente da observância de contraditório, e outros casos em que a antecipação ocorre já com a relação processual instaurada (v.g., o do art. 225 do CPP), com a necessária participação das partes ${ }^{, 255}$, embora nos pareça mais acertado buscar assegurar, tanto quanto possível, o contraditório também na prova cautelar ${ }^{256}$.

${ }^{253}$ Cf. JOSÉ BARCELOS DE SOUZA, Dificuldades na prática do direito: produção antecipada de prova e prova ad perpetuam memoriam, com a reforma processual penal de 2008, artigo ainda no prelo, a ser publicado em obra jurídica em homenagem ao Professor Sérgio Demoro Hamilton, pela Editora Lumen Juuris, Rio de Janeiro apud MARCELLUS POLASTRI LIMA, A prova penal de acordo com a reforma processual penal, $3^{\text {a }}$ ed., Rio de Janeiro, Lumen Juris, 2009, p. 286.

${ }^{254} \mathrm{Cf}$. A prova penal de acordo com a reforma processual penal, $3^{\mathrm{a}}$ ed., Rio de Janeiro, Lumen Juris, 2009, p. 56. Em outro capítulo do livro (p. 287), o autor, ao tratar da prova testemunhal, assevera ser "necessário distinguir entre produção e asseguração da prova, para ver se se trata de mero depoimento produzido antecipadamente ou prova ad perpetuam rei memoriam. O primeiro é feito com o processo já formado, mas antes da audiência designada, em face da premência de tempo; o segundo é feito antes de o processo ser formado (v. g., em fase de investigação) e terá que aguardar em cartório para ser juntado posteriormente aos autos do processo futuro".

${ }^{255}$ Cf. Provas - Lei 11.690, de 09.06.2008 in As reformas no processo penal - as novas leis de 2008 e os projetos de reforma, coord. Maria Thereza Rocha de Assis Moura, São Paulo, Revista dos Tribunais, 2008, p. 253.

${ }^{256}$ Imperioso ainda mencionar que a distinção entre provas cautelares e antecipadas levada a efeito na atualidade pelos processualistas penais brasileiros encontra respaldo na diferenciação da doutrina processual civil mais tradicional. OVÍDIO A. BAPTISTA DA SILVA já observava que o Código de Processo Civil tratava "promiscuamente" das ações cautelares de asseguração de depoimentos e da produção antecipada de prova testemunhal, como se fossem a mesma coisa, quando, na verdade, não eram. Segundo o autor, a distinção é essencial e inapagável: "não basta, para confundi-la, que o legislador assim o deseje. O juiz que preside a instrução preventiva, proposta antes do ajuizamento da causa, sob forma de ação cautelar, certamente ainda não recebe a prova como seu destinatário natural, pois só o juiz da causa onde ela deva ser afinal produzida, averiguará de sua legitimidade e pertinência e a receberá como prova; coisa essencialmente diversa ocorre quando o próprio juiz da causa, que às vezes, já admitiu o depoimento no 
Com base nas distinções acima formuladas, seria possível perquirir sobre quais tipos de provas se referem os artigos 225 e 366 do Código de Processo Penal. O primeiro $^{257}$, ao permitir a antecipação do depoimento de uma testemunha que justificadamente tiver de ausentar-se, ou caso haja fundado receio de que, por motivo de enfermidade ou velhice, sua oitiva não possa se dar na fase instrutória do processo penal, parece aludir tanto à prova cautelar ${ }^{258}$ como à antecipada. Isto porque a medida pode ser determinada de ofício (o que, a princípio, só se deve admitir no curso do processo, sob pena de violação ao princípio acusatório) ou a requerimento das partes (o que pode se dar antes ou depois de ajuizada a ação penal) ${ }^{259}$.

Imperioso, no entanto, mencionar a existência de entendimento segundo o qual a hipótese do art. 225 trata apenas de produção emergencial e antecipada da prova. $\mathrm{O}$ jurista VINICIUS DE TOLEDO PIZA PELUSO sustenta tal posicionamento, pois vislumbra a realização da medida prevista no art. 225 do CPP apenas depois de já instaurado o processo, hipótese em que "a relação processual penal está completa, com a presença do réu (devidamente citado) e seu defensor constituído, ocorrendo que a antecipada oitiva das testemunhas será acompanhada pela parte e seu defensor que, assim, participarão ativamente na produção da prova, que somente foi antecipada em razão de situações especialíssimas "260. Aludida interpretação do art. 225 do CPP, todavia, além de restringir muito sua aplicabilidade, impedindo a colheita de prova oral nas mesmas circunstâncias durante a fase de investigação, contraria o disposto no art. 156, I do CPP, que faculta ao juiz ordenar, mesmo antes de iniciada a ação penal, a produção de provas consideradas urgentes e relevantes.

momento adequado, defere a sua produção antecipada, por ocorrer algum dos pressupostos aceitos pela lei como índice de perigo de perda ou grave dificultação da produção da prova no momento próprio. Aqui o juiz admite a antecipação do depoimento e o recebe, desde logo, como prova”. Cf. Comentários ao Código de Processo Civil, vol. XI, 2ª ed., Porto Alegre, Letras Jurídicas, 1986, p. 453. No mesmo sentido, o comentário de PONTES DE MIRANDA a seguir transcrito: "cumpre distinguir-se do depoimento da testemunha, de natureza cautelar mas prévia, o depoimento antecipado, interrogatório ou inquirição, se o depoimento é para a ação já proposta, regulado pelo art. $847,2^{a}$ parte [do CPC]. Não há dúvida que se procede antecipadamente por cautela; mas o depoimento, aí, já é parte da instrução”. Cf. Comentários ao Código de Processo Civil, t. XII, Rio de Janeiro, Forense, 1973, p. 267.

${ }^{257}$ Eis a previsão do aludido dispositivo legal: “Art. 225. Se qualquer testemunha houver de ausentar-se, ou, por enfermidade ou por velhice, inspirar receio de que ao tempo da instrução criminal já não exista, o juiz poderá, de oficio ou a requerimento de qualquer das partes, tomar-lhe antecipadamente o depoimento".

${ }^{258}$ Para JOÃO GUALBERTO GARCEZ RAMOS, a providência prevista no art. 225 do CPP é uma autêntica medida cautelar instrutória, pois preenche todas as notas características de provimentos dessa natureza. Cf. $A$ tutela de urgência no processo penal brasileiro, Belo Horizonte, Del Rey, 1998, p. 276.

${ }^{259} \mathrm{O}$ entendimento é partilhado por MARCELLUS POLASTRI LIMA. Cf. A prova penal de acordo com a reforma processual penal, $3^{\text {a }}$ ed., Rio de Janeiro, Lumen Juris, 2009, p. 288.

${ }^{260}$ Cf. Revelia e produção antecipada da prova testemunhal in Revista Brasileira de Ciências Criminais, $\mathrm{n}^{\mathrm{o}}$ 72, v. 16, 2008, p. 195. 
No que diz respeito ao artigo $366^{261}$ do referido diploma, por autorizar a antecipação de provas urgentes na hipótese de citação por edital, em que o réu não comparece à audiência, comporta diferentes interpretações: considerando que já existe processo quando da realização da medida, estar-se-ia adiante da produção antecipada de prova. O entendimento, no entanto, não se afigura o mais correto, uma vez que, embora já exista processo, o réu não se faz presente nem representado nos autos; a finalidade da colheita de tal prova é meramente conservá-la para eventual utilização no futuro. Tratar-seia, pois, de típica hipótese de prova cautelar ${ }^{262}$.

Ainda em relação ao art. 366 do Código de Processo Penal, não se poderia deixar de mencionar a necessidade de que a colheita da prova se mostre de fato urgente para a decretação de sua realização. Nas palavras de GUILHERME DE SOUZA NUCCI, "somente as provas realmente pereciveis precisam ser efetivadas na ausência do réu, ainda que lhe seja nomeado defensor dativo ou indicado defensor público. Dentre as que demandam maior controvérsia está, inequivocamente, a prova testemunhal,263. A lembrança do autor é salutar, na exata medida em que, pelo fato de a passagem do tempo poder dissipar a memória da testemunha acerca dos fatos relevantes à causa, passou-se a sustentar que a produção da prova testemunhal seria sempre urgente.

Aliás, recorda ANTONIO SCARANCE FERNADES que, também por conta da previsão dos artigos 92 e $93^{264}$ do CPP o entendimento acima ganhou força, já que, ao tratarem da suspensão do processo decorrente de questão prejudicial, os dispositivos equipararam a prova testemunhal às provas urgentes. Alerta, no entanto, o autor, que tal não foi o objetivo do legislador com a redação dada ao art. 366. Sua intenção

\footnotetext{
${ }^{261}$ Estatui o aludido art. 366 do Código de Processo Penal o seguinte: "Se o acusado, citado por edital, não comparecer, nem constituir advogado, ficarão suspensos o processo e o curso do prazo prescricional, podendo o juiz determinar a produção antecipada das provas consideradas urgentes e, se for o caso, decretar prisão preventiva, nos termos do disposto no art. 312 ”.

${ }^{262}$ Cf. ANTONIO SCARANCE FERNANDES, Processo penal constitucional, $6^{\mathrm{a}}$ ed., São Paulo, Revista dos Tribunais, 2010, p. 274, GUILHERME DE SOUZA NUCCI, Código de processo penal comentado, 9ª ed., São Paulo, Revista dos Tribunais, 2009, p. 674 e VINICIUS DE TOLEDO PIZA PELUSO, Revelia e produção antecipada da prova testemunhal in Revista Brasileira de Ciências Criminais, nº 72, v. 16, 2008, pp. 195-196.

${ }^{263}$ Cf. Código de processo penal comentado, 9aㅡ ed., São Paulo, Revista dos Tribunais, 2009, p. 673.

264 Eis o que estatuem os aludidos dispositivos: "Art. 92. Se a decisão sobre a existência da infração depender da solução de controvérsia, que o juiz repute séria e fundada, sobre o estado civil das pessoas, o curso da ação penal ficará suspenso até que no juízo cível seja a controvérsia dirimida por sentença passada em julgado, sem prejuízo, entretanto, da inquirição das testemunhas e de outras provas de natureza urgente" (grifo nosso) e "Art. 93. Se o reconhecimento da existência da infração penal depender de decisão sobre questão diversa da prevista no artigo anterior, da competência do juízo cível, e se neste houver sido proposta ação para resolvê-la, o juiz criminal poderá, desde que essa questão seja de difícil solução e não verse sobre direito cuja prova a lei civil limite, suspender o curso do processo, após a inquirição das testemunhas e realização das outras provas de natureza urgente" (grifo nosso).
} 
teria sido a de "assegurar ao acusado maior amplitude de defesa em todo o processo e, seguramente, durante a produção da prova, principalmente a testemunhal, ${ }^{, 265}$.

ANTONIO MAGALHÃES GOMES FILHO foi um dos juristas que defendeu a impossibilidade de sempre se decretar a produção de prova testemunhal quando o processo for suspenso com base no art. 366 do CPP. Segundo o autor, "essa antecipação na colheita da prova não deverá ser, certamente, uma rotina nos casos em que houve a suspensão do processo diante da ausência do réu citado por edital, mas providência resultante da avaliação do risco concreto de impossibilidade na obtenção futura de informações necessárias ao êxito da persecução",266.

A discussão sobre a aplicabilidade do art. 366 do CPP chegou ao Superior Tribunal de Justiça, que, ao pacificar o entendimento sobre a matéria, editou a Súmula $\mathrm{n}^{\mathrm{o}}$ 455, com o seguinte teor: "a decisão que determina a produção antecipada de provas com base no art. 366 do CPP deve ser concretamente fundamentada, não a justificando unicamente o mero decurso do tempo". Ou seja, prevaleceu o entendimento segundo o qual a mera suspensão do processo na hipótese do art. 366 do CPP não é motivo suficiente para a produção antecipada de prova testemunhal ou qualquer outra: a urgência e a relevância da medida devem ser demonstradas para que a mesma seja decretada.

Retomando, assim, a comparação entre as chamadas provas irrepetíveis, cautelares e antecipadas, não obstante seja possível distingui-las, tal como se tentou empreender logo acima, deve-se reparar que, de maneira geral, as expressões são tratadas como equivalentes pela doutrina pátria. Por exemplo, a locução "produção antecipada da prova" é usada indistintamente por vários juristas para designar tanto a colheita unilateral de provas urgentes e irrepetíveis na fase investigatória da persecução, sem a intervenção do juiz e que deverão ser submetidas ao contraditório diferido ${ }^{267}$, como a realização de provas também importantes e urgentes, na presença das partes e do magistrado ${ }^{268}$.

${ }^{265}$ Cf. Processo penal constitucional, 6a ed., São Paulo, Revista dos Tribunais, 2010, p. 275. Prossegue o autor: "De que adiantaria a suspensão para a defesa se as testemunhas fossem sempre ouvidas sem a sua presença e de advogado de sua confiança? Teria a regra do art. 366 garantido ao acusado apenas o direito de formulação das alegações finais e de não ser julgado até que comparecesse, mas não teria a possibilidade de influir na prova que poderá fundamentar a sua condenação”.

${ }^{266}$ Cf. Medidas cautelares da Lei 9.271/96: produção antecipada de provas e prisão preventiva in Boletim do Instituto Brasileiro de Ciências Criminais, n⿳⺈ 42, junho de 1996, p. 05.

${ }^{267}$ Por exemplo, ADA PELLEGRINI GRINOVER, ANTONIO SCARANCE FERNANDES e ANTONIO MAGAlHÃES GOMES FILHO. Cf. As nulidades no processo penal, $11^{\mathrm{a}}$ ed., São Paulo, Revista dos Tribunais, 2009, p. 145.

${ }^{268}$ Cf. AURY LOPES JR., Sistemas de investigação preliminar no processo penal, Rio de Janeiro, Lumen Juris, 2001. p. 125. 
Na verdade, o próprio Código de Processo Penal brasileiro não foi rigoroso ao tratar das diferentes hipóteses de prova mencionadas no art. 155 do diploma. Em outros de seus dispositivos, como visto, fala-se genericamente em produção antecipada de provas. No âmbito processual civil, verificou-se o mesmo fenômeno. Como observa OVÍDIO A. BABTISTA DA SILVA, tanto a legislação brasileira como a portuguesa e a italiana não diferenciam as hipóteses de asseguração e produção antecipada da prova ${ }^{269}$.

Diante desse cenário, a distinção entre provas irrepetíveis, cautelares e antecipadas não será adotada com extremo rigor neste trabalho, e sim na medida em que possível.

Oportuno ainda mencionar que, embora no âmbito processual civil seja defensável a idéia de produção antecipada de provas sem o requisito da urgência ${ }^{270}$, no processo penal, a hipótese, se não for refutada de pronto, deve ser analisada com muita cautela, pois, como visto, a própria dinâmica criminal obsta a instalação do contraditório antes de iniciado o processo, e mesmo a cognição plena acerca dos fatos sobre os quais versa a causa não é desejável em tal momento da persecução. Ademais, no processo penal não se sabe de antemão exatamente contra quem será utilizada esta prova antecipada (diferentemente do que ocorre no processo civil, onde as futuras partes de eventual demanda são desde logo conhecidas, pois correspondem aos titulares da relação jurídica de direito material).

O jurista FLÁVIO LUIZ YARSHELL, que sustenta ser possível antecipar a produção da prova mesmo nos casos em que não há perigo na demora, o faz partindo da premissa de que no próprio exercício do direito à investigação já se está a produzir provas. No entendimento do autor, "buscar a fonte, no mais das vezes, é também empregar o meio de prova”, ou produzi-la de forma antecipada (pré-constituição) ${ }^{271}$.

No entanto, como visto, no processo penal a asserção não se aplica, já que investigar, ou seja, buscar as fontes de prova, é uma atividade exercida unilateralmente, via de regra, sem o necessário contraditório exigido para a produção dos meios de prova. No

\footnotetext{
${ }^{269}$ Cf. Comentários ao Código de Processo Civil, vol. XI, 2ª ed., Porto Alegre, Letras Jurídicas, 1986, p. 453.

${ }^{270}$ O jurista FLÁVIO LUIZ YARSHELL sustenta firmemente tal posicionamento, pois, na visão do autor, o direito à prova é autônomo, existe independentemente do processo, e se destina precipuamente à formação do convencimento das partes acerca de suas chances de êxito em eventual processo declaratório. Cf. Antecipação da prova sem o requisito da urgência e direito autônomo à prova, São Paulo, Malheiros, 2009, p. 232, e ao longo de toda a obra.

${ }^{271}$ Cf. Antecipação da prova sem o requisito da urgência e direito autônomo à prova, São Paulo, Malheiros, 2009, pp. 212-213.
} 
exercício do direito à investigação, não há nem a presença da parte contrária nem a do juiz, ambas imprescindíveis para a garantia do contraditório ${ }^{272}$. Ademais, no âmbito penal, até mesmo as atividades empregadas para a realização da investigação são diversas dos instrumentos usados para a produção da prova. Costuma-se arrolar como meios de investigação ou de pesquisa das provas as interceptações telefônicas, as buscas e apreensões, inspeções, entre outros. Já os meios de prova seriam a prova documental, testemunhal, pericial, acareações, reconhecimentos, reconstituições.

Como se vê, em matéria criminal, a atividade de investigação não se confunde com a atividade de produção da prova. Apenas se admite, excepcionalmente, que os atos realizados no seio de uma investigação anterior ao processo sejam usados como prova em sentido estrito quando forem irrepetíveis, de urgente realização e importantes para o feito. Ainda assim, deverão ser submetidos ao contraditório diferido ${ }^{273}$.

Reafirme-se ainda que a antecipação das provas sem o requisito da urgência no âmbito penal tampouco se afigura desejável sob o aspecto da profundidade da cognição levada a efeito antes da instauração do processo. Não se objetiva um conhecimento pleno acerca dos fatos relevantes para a causa antes da instauração do processo, pois para este ter início basta a probabilidade da materialidade e da autoria delitiva. Apenas para a prolação da decisão final, de mérito, é que se faz necessário um juízo de certeza sobre tais aspectos.

Nesse sentido, observa AURY LOPES JR. que, como para a admissão de uma ação penal ou aplicação de uma medida cautelar pessoal não é necessário um juízo de certeza sobre a existência do delito e sua autoria, bastando meramente um juízo de probabilidade, ou seja, um predomínio das razões positivas, a cognição realizada durante a investigação anterior ao processo é sumária, limitada, superficial. Segundo o autor, " $a$ instrução preliminar não deve ser normativamente uma cognição plena, profunda $e$ completa sobre a existência do delito, pois esse é o objetivo da fase processual e da instrução definitiva. Uma fase pré-processual plenária não representa mais do que uma

${ }^{272}$ Como bem observam ADA PELLEGRINI GRINOVER, ANTONIO MAGALHÃES GOMES FILHO e ANTONIO SCRANCE FERNANDES, "tanto será viciada a prova que for colhida sem a presença do juiz, como o será a prova colhida pelo juiz, sem a presença das partes". Cf. As nulidades no processo penal, $11^{\mathrm{a}}$ ed., São Paulo, Revista dos Tribunais, 2009, p. 114.

${ }^{273}$ Sobre o assunto, assevera expressamente ANTONIO MAGALHÃES GOMES FILHO que "somente quando tiver sido imprevisivel a impossibilidade de renovação da prova será viável utilizar os elementos anteriormente obtidos sem o contraditório". Mas ressalva ainda o autor que "sua eventual utilização no processo não afasta a necessidade de submetê-la ao contraditório diferido, permitindo-se às partes discutir a sua admissibilidade, regularidade e idoneidade". Cf. Provas - Lei 11.690, de 09.06.2008 in As reformas no processo penal - as novas leis de 2008 e os projetos de reforma, coord. Maria Thereza Rocha de Assis Moura, São Paulo, Revista dos Tribunais, 2008, p. 255. 
molesta duplicidade ou, ainda pior, desvirtua completamente a fase processual, transformando-se na alma do processo ${ }^{, 274}$.

Ao tratar dos diferentes standards probatórios, GUSTAVO HENRIQUE RIGHI IVAHY BADARÓ também assevera que é suficiente um mero juízo de probabilidade para a concessão de medidas cautelares anteriores ao processo, e mesmo para o recebimento da denúncia, ressaltando, porém o autor que, como a certeza absoluta é inatingível, deve ser tida como altíssimo grau de probabilidade ${ }^{275}$.

Seja como for, fato é que, como não se objetiva o exaurimento da cognição acerca do fato penal na fase investigatória, a produção antecipada de provas sem o requisito da urgência neste momento da persecução penal não se mostra adequada nem desejável.

Por fim, cumpre apenas salientar que, embora a aludida antecipação da prova não urgente seja praticamente desconsiderada na seara criminal, há quem sustente a possibilidade de realização das "justificações” previstas no Código de Processo Civil também no âmbito penal, justificações estas que prescindem do requisito da urgência.

Na lição de OVÍDIO A. BAPTISTA DA SILVA, consistiria a justificação na ação destinada a constituir prova da existência de algum fato ou relação jurídica, sendo que, diferentemente do que ocorre na asseguração da prova, em que se exige o perigo da demora e não há efetiva produção da prova, na justificação inexiste o requisito da urgência, e há verdadeira constituição da prova. O autor lembra ainda outra diferença: na tomada de provas ad perpetuam rei memoriam, o juiz apenas colhe os elementos da prova a ser produzida no futuro, sem analisá-la, ao passo que, na justificação, o magistrado dá por existentes, na sentença, os fatos ou relações jurídicas sobre os quais versou a medida ${ }^{276}$.

\footnotetext{
${ }^{274}$ Cf. Sistemas de investigação preliminar no processo penal, Rio de Janeiro, Lumen Juris, 2001, pp. 92-94. Arremata o jurista, afirmando que "é inadmissivel que a investigação preliminar seja ou converta-se em plenária, não só porque atrasa todo o processo, mas também porque tende a converter os meros atos de investigação - praticados muitas vezes em segredo e sem qualquer contraditório - em atos de prova, transformando a fase processual num mero trâmite para valorar e sentenciar. Em definitivo, o sistema plenário degenera o processo e a sua estrutura dialética, pois fulmina a igualdade de oportunidades e o contraditório. Também causa a insatisfação geral pela sensação de repetição de atos, quando na verdade nunca deveriam ter sido produzidos na investigação preliminar, mas sim reservados para o processo".

${ }^{275}$ Segundo o jurista, a certeza processual significa o grau mais elevado de probabilidade, um convencimento judicial racional além de qualquer dúvida razoável. Cf. Ônus da prova no processo penal, São Paulo, Revista dos Tribunais, 2003, pp. 54-55.

${ }^{276}$ Cf. Comentários ao Código de Processo Civil, vol. XI, 2ª ed., Porto Alegre, Letras Jurídicas, 1986, pp. 546-549.
} 
Ou seja, embora no Código de Processo Civil vigente a ação de justificação tenha sido incluída no Livro III, que trata do processo cautelar, entende-se na verdade que aludida ação não é cautelar, pois não se funda no periculum in mora.

Explica HUMBERTO THEODORO JÚNIOR que a justificação é uma "medida de constituição avulsa de prova, sem o caráter de prevenção que se nota nas antecipações cautelares de prova (vistorias e inquirições ad perpetuam rei memoriam) $e$ sem a acessoriedade que é essencial a estas, uma vez que a justificação pode simplesmente servir como documentação, exaurindo em si mesma sua finalidade processual,"277.

Para FLÁVIO LUIZ YARSHELL, a justificação é o exemplo maior da possibilidade de produção antecipada de prova sem o requisito da urgência. Em suas próprias palavras, "é na seara da referida medida [justificação] que a produção antecipada e autônoma da prova - desligada da urgência e da declaração do direito em "processo regular" - parece alcançar seu ápice. E, embora haja tentativa de se distinguir a produção antecipada de prova da justificação, os critérios apontados não convencem ou, quando menos, não superam a convergência que existe entre uma e outra, e que reside na pré-constituição de prova. Ambas se afiguram, enfim, como meios pelos quais o sistema admite a produção de prova de forma autônoma" 278 . Caso se considere, porém, que a produção antecipada de provas no processo penal não prescinde do requisito da urgência, tal como se está aqui a sustentar, afigura-se impossível afirmar que a medida equivale à justificação, que dispensa o mesmo requisito.

A propósito, da leitura do art. 861 do Código de Processo Civil, depreendese que a justificação pode ter por finalidade servir apenas como documento para quem a promove, sem caráter contencioso, ou então servir efetivamente como prova em futuro processo.

Necessário, porém, ressaltar que a ação de justificação deve ao menos ser fundada em interesse legítimo (como todos os pedidos de tutela jurisdicional, aliás) ${ }^{279}$.

\footnotetext{
${ }^{277}$ Cf. Processo cautelar, $22^{\mathrm{a}}$ ed., São Paulo, Liv. e Ed. Universitária de Direito, 2005, pp. 348-349.

${ }^{278} \mathrm{Cf}$. Antecipação da prova sem o requisito da urgência e direito autônomo à prova, São Paulo, Malheiros, 2009, pp. 422-423.

${ }^{279}$ Cf. OVÍDIO A. BAPTISTA DA SILVA, Comentários ao Código de Processo Civil, vol. XI, 2 $2^{\mathrm{a}}$ ed., Porto Alegre, Letras Jurídicas, 1986, p. 547. Ao tratar do direito à investigação, FLÁVIO LUIZ YARSHELL faz observação semelhante, ao salientar a necessidade de "justa causa" para a investigação. Segundo o autor, a investigação, para ser realizada, deve necessariamente estar ligada a uma relação material controvertida. Cf. Antecipação da prova sem o requisito da urgência e direito autônomo à prova, São Paulo, Malheiros, 2009, p. 220.
} 
Pois bem, se no campo civil as justificações são não apenas admitidas como também regulamentadas em lei, no campo penal sua aplicabilidade não é tão clara, pela própria ausência de previsão legal nesse sentido. Tal é o posicionamento de AURY LOPES $\mathrm{JR}^{280}$, por exemplo. Mas há juristas como MARCELLUS POLSATRI LIMA ${ }^{281}$ e JOSÉ FREDERICO MARQUES que sustentam ser possível o uso da justificação também na seara criminal, por exemplo, em incidentes relativos à indenização pelo dano resultante do delito, ou como procedimento preparatório para constituir prova em pedido de habeas corpus, ou ainda para fins de instrução do pedido formulado em revisão criminal ${ }^{282}$.

\subsubsection{Abuso do direito à investigação}

Sem a pretensão de analisar profundamente ou esgotar o tema do abuso de direitos processuais, dada sua amplitude e complexidade ${ }^{283}$, buscar-se-á aqui examinar, em linhas gerais, o abuso do direito à investigação na seara criminal.

Como se sabe, ocorre abuso de um direito quando dele não é feito o uso regular, esperado. No que diz respeito ao abuso de direito processual, entende-se que ele ocorre, basicamente, quando há um desvio de finalidade na prática de determinado ato processual. Segundo HELENA NAJJAR ABDO, o abuso de direito processual se manifesta sempre que "uma determinada escolha desvia ou deturpa a finalidade do

${ }^{280}$ Cf. Sistemas de investigação preliminar no processo penal, Rio de Janeiro, Lumen Juris, 2001, p. 192.

${ }^{281} \mathrm{Cf}$. A prova penal de acordo com a reforma processual penal, $3^{\mathrm{a}}$ ed., Rio de Janeiro, Lumen Juris, 2009, p. 284.

${ }^{282}$ Cf. Elementos de direito processual civil, vol. II, Campinas, Millennium Editora, 2009, p. 316. Também sustentam o cabimento da justificação na esfera criminal ALEXANDRA LEBELSON SZAFIR, Competência para justificação prévia preparatória de revisão criminal in Boletim do Instituto Brasileiro de Ciências Criminais, $\mathrm{n}^{\mathrm{0}}$ 37, janeiro de 1999, p. 08, e LEÔNIDAS RIBEIRO SCHOLZ e ANDRÉ PIRES DE ANDRADE KEHDI, Cabimento de perícia em sede de justificação prévia de natureza criminal in Boletim do Instituto Brasileiro de Ciências Criminais, no 177, agosto de 2007, pp. 15-16.

${ }^{283}$ Como bem observa FLÁVIO LUIZ YARSHELL, há enorme dificuldade em definir tecnicamente o que seja abuso de direito, tanto que este é um tema discutido há muito tempo na seara da teoria geral do direito e em diferentes campos do direito privado e público, inclusive processual. Neste último, segundo o autor, "cogita-se do abuso no exercício dos direitos de ação, de defesa e das posições jurídicas que deles resultam, quando vistos em uma perspectiva analítica; ai incluído o direito de provar, quer se pensado como desdobramento da ação e da defesa, quer, ainda, se entendido como prerrogativa de pedir ao Estado tãosomente a produção de certa prova". Cf. Antecipação da prova sem o requisito da urgência e direito autônomo à prova, São Paulo, Malheiros, 2009, pp. 195-196.

Complementa ainda LUIZ SERGIO FERNANDES SOUZA que "o problema central que orienta a pesquisa sobre o abuso dos direitos processuais diz respeito à existência de limites à atuação daqueles que, em tese, agem em conformidade com a norma legal. Na perspectiva do formalismo jurídico, ou se exerce um direito, pelo que não se pode cogitar de abuso, ou então se está praticando um ilícito, razão pela qual também não há de se falar em abuso. A discussão, posta nestes termos, aponta para a dificuldade em separar o direito e a moral, a norma e aplicação do direito, distinções que surgem somente quando o pensamento jurídico se dá conta do contraste entre o ordenamento normativo e os fatos". Cf. Abuso de direito processual - uma teoria pragmática, São Paulo, Revista dos Tribunais, 2005, p. 11. 
processo como um todo ou do próprio instrumento ou meio processual utilizado para a prática do ato”, sendo que também são característicos do abuso de direito processual a aparência de legalidade do ato e o exercício de uma situação jurídica subjetiva (poder, dever, ônus ou faculdade) ${ }^{284}$.

Também se colhem na doutrina opiniões no sentido de que o abuso de direito processual se verifica quando o exercício de determinada prerrogativa excede os limites impostos pela boa-fé ou pelos bons costumes, contraria os objetivos perseguidos pela norma, ou viola outros direitos e garantias igualmente assegurados ${ }^{285}$.

Para WINFRIED HASSEMER, "o abuso de direito começa precisamente ali, onde o titular de um direito utiliza o mesmo na forma de um instrumento de lesão. Ao invés de usá-lo como um instrumento útil, o que na realidade é, emprega-o para dele abusar,"286.

No processo civil, o abuso do direito à prova, e, mais amplamente, de direitos processuais, encontra regulamentação não só no Brasil, mas também em outros países. Nos Estados Unidos, por exemplo, é utilizada a expressão “abuse discovery” para tratar das postulações de ordem probatória que causam embaraço, opressão, gasto ou ônus excessivo, ou que são realizadas no intuito de causar atrasos ou despesas à parte contrária $^{287}$.

A fim de coibir tais condutas, afastando ou minimizando o abuso do direito à prova e do direito à investigação, foram previstas no direito norte-americano medidas protetivas, que podem ter função repressiva ou preventiva (as chamadas "protective order"). Ocorre, porém, que a própria dificuldade em distinguir a "discovery" abusiva da

\footnotetext{
${ }^{284}$ Cf. Fundamentos sistemáticos do abuso do processo no direito processual civil, Dissertação de Mestrado apresentada à Faculdade de Direito da Universidade de São Paulo em 2002, pp. 298-299.

${ }^{285}$ Cf. CARLA SILENE CARDOSO LISBOA BERNARDO GOMES, Inexistência de multa por litigância de má-fé no processo penal in Análise de precedentes criminais do Superior Tribunal de Justiça - Estudos em homenagem à Desembargadora Jane Ribeiro Silva, Belo Horizonte, Ed. Atualizar, 2009, p. 76.

${ }^{286} \mathrm{O}$ excerto foi traduzido livremente do seguinte: "el abuso del derecho comienza precisamente allí, donde el titular de un derecho redirecciona el mismo en la forma de un instrumento de lesión. En lugar de utilizarlo como un instrumento útil, lo que en realidad es, lo emplea para abusar de él”. Cf. Sobre el abuso de los derechos in Revista de Ciências Jurídicas ¿Más derecho?, nº 3, 2003, p. 29.

${ }^{287}$ Cf. FLÁVIO LUIZ YARSHELL, Antecipação da prova sem o requisito da urgência e direito autônomo à prova, São Paulo, Malheiros, 2009, pp. 196-197. O autor traz inúmeros exemplos de "abuse discovery": requerimento de informações inúteis ou excessivas com objetivo de atormentar a parte contrária ("overuse of discovery" ou "overdiscovery"), fornecimento de elevado número de documentos para dificultar sua análise pela parte adversa ("bulk discovery" ou "hide and seek play"), requerimento genérico e vago de informações ("fishing expedition"), recusa ao fornecimento de informações requeridas, sob a falsa alegação de impossibilidade de colaboração, destruição de documentos, entre outros.
} 
agressiva, e de identificar o responsável pelo abuso (parte ou advogado) faz com que apenas os casos flagrantes de "abuse discovery" sejam lá sancionados ${ }^{288}$.

No Brasil, o tema do abuso de direitos processuais vem sendo estudado há bastante tempo pela doutrina processual civil, e encontrava regulamentação já no Código de Processo Civil de 1939, o qual arrolava como modalidades de tal abuso as seguintes: dolo, temeridade, fraude, emulação, capricho, erro grosseiro, violência, protelação da lide, falta ao dever de dizer a verdade, e situação intermediária do poder de disposição no processo $^{289}$.

O Código de Processo Civil de 1973, que se encontra em vigor, optou por evitar a utilização da nomenclatura do direito civil (erro, dolo, fraude, etc.) para tratar do abuso de direitos processuais, o que, segundo RUI STOCO, seguiu a tendência dos códigos europeus de valorizar, principalmente, o princípio da probidade na atuação dos litigantes em uma contenda judicial. No entanto, segundo o autor, os conceitos de abuso de direito processual, litigância de má-fé, e má-fé processual encontram fundamento no abuso de direito material ${ }^{290}$.

Para HELENA NAJJAR ABDO, a doutrina do abuso do processo extrai do direito privado sobretudo as noções de aparência de legalidade, relatividade dos direitos e desvio de finalidade, mas há peculiaridades inerentes ao próprio processo, em especial a de que a conduta abusiva é cometida no âmbito de uma relação jurídica processual, em que são possíveis titulares do abuso as partes, e onde o objeto do abuso não é um direito subjetivo, mas sim uma situação subjetiva processual ${ }^{291}$.

Pois bem, verificada a prática de um ato abusivo no âmbito do processo civil, surge como conseqüência a imposição de uma sanção, a qual pode ser de variadas ordens em nosso sistema: nulidade ou ineficácia do ato abusivo, imposição de multa, condenação em perdas e danos, restrição de direitos, responsabilidade criminal do agente, entre outras ${ }^{292}$.

\footnotetext{
${ }^{288}$ Cf. FLÁVIO LUIZ YARSHELL, Antecipação da prova sem o requisito da urgência e direito autônomo à prova, São Paulo, Malheiros, 2009, pp. 197-198.

${ }^{289}$ Cf. JOSÉ OLÍMPIO DE CASTRO FILHO, Abuso do direito no processo civil, 2ª ed., Rio de Janeiro, Forense, 1960, pp. 87-88.

${ }^{290}$ Cf. Abuso do direito e má-fé processual, São Paulo, Revista dos Tribunais, 2002, p. 65.

${ }^{291}$ Cf. Fundamentos sistemáticos do abuso do processo no direito processual civil, Dissertação de Mestrado apresentada à Faculdade de Direito da Universidade de São Paulo em 2002, p. 297.

${ }^{292}$ Cf. JOSÉ OĹ́MPIO DE CASTRO FILHO, Abuso do direito no processo civil, $2^{\underline{a}}$ ed., Rio de Janeiro, Forense, 1960, p. 192, e HELENA NAJJAR ABDO, Fundamentos sistemáticos do abuso do processo no
} 
No mais das vezes, o abuso de direito processual acarreta a chamada litigância de má-fée ${ }^{293}$. O Código de Processo Civil (CPC), em seu art. 14, impõe às partes e a todos aqueles que participam do processo os deveres de veracidade, de lealdade, de boafé, e de não produzir provas nem praticar atos inúteis ou desnecessários à declaração ou defesa de direito. $\mathrm{O}$ art. 17 do mesmo diploma arrola ainda as condutas que caracterizam litigância de má-fé, entre as quais a de alterar a verdade dos fatos. Tais condutas podem ser sancionadas a requerimento das partes ou de ofício pelo magistrado, através da imposição de multa não excedente a $1 \%$ do valor da causa, além da fixação de indenização pelos prejuízos causados, mais honorários advocatícios e despesas processuais, nos termos do art. 18 do CPC.

Todo o raciocínio acima exposto aplica-se ao processo civil. O sistema processual penal pátrio, por sua vez, não conta com regras expressas relativas ao abuso de direitos processuais, nem alude à litigância de má-fé nas leis que o regem. Poder-se-ia, pois, aventar a hipótese de aplicação por analogia das regras do processo civil relativas ao tema. Tal solução, contudo, não se mostra acertada, uma vez que não existe propriamente lacuna legislativa em nosso regramento processual penal no que se refere à matéria em análise $^{294}$. Na verdade, são os princípios, direitos e garantias próprios do processo penal que dificultam, ou até mesmo impedem, cogitar-se de abuso de direito processual, litigância de má-fé e aplicação de suas respectivas sanções na seara criminal ${ }^{295}$.

Lembra WINFRIED HASSEMER que a defesa penal tem direitos especiais, derivados da garantia do devido processo legal, além do que, diferentemente do que ocorre no processo civil, no criminal não é tarefa fácil identificar os danos causados pelos atos praticados em abuso de direito, muito menos calculá-los ${ }^{296}$.

De fato, alguns institutos e prerrogativas exclusivos do processo penal, como a ampla defesa e o princípio da presunção de inocência, dificultam, senão obstam, o

direito processual civil, Dissertação de Mestrado apresentada à Faculdade de Direito da Universidade de São Paulo em 2002, p. 265.

${ }^{293}$ Cf. CARLA SILENE CARDOSO LISBOA BERNARDO GOMES. Cf. Inexistência de multa por litigância de má-fé no processo penal in Análise de precedentes criminais do Superior Tribunal de Justiça Estudos em homenagem à Desembargadora Jane Ribeiro Silva, Belo Horizonte, Ed. Atualizar, 2009, p. 75.

${ }^{294}$ Cf. CARLA SILENE CARDOSO LISBOA BERNARDO GOMES, Inexistência de multa por litigância de má-fé no processo penal in Análise de precedentes criminais do Superior Tribunal de Justiça - Estudos em homenagem à Desembargadora Jane Ribeiro Silva, Belo Horizonte, Ed. Atualizar, 2009, p. 84.

${ }^{295}$ Também no processo penal italiano ELENA MARIA CATALANO chama atenção para o fato de que o conceito de abuso processual e as classificações elaboradas pela doutrina processual-civil não são plenamente suscetíveis de transposição para o terreno processual penal. Cf. L'abuso del processo, Milano, Giuffrè, 2004, p. 32.

${ }^{296}$ Cf. Sobre el abuso de los derechos in Revista de Ciências Jurídicas ¿Más derecho?, nº 3, 2003, p. 31. 
reconhecimento do abuso de direitos processuais, em especial do direito à investigação, na esfera penal.

O próprio art. 5 LV, da Constituição Federal de 1988 assegura aos acusados em geral a ampla defesa, com os meios e recursos a ela inerentes. No exercício deste direito, o imputado pode realizar uma série de atos e se abster de realizar outros tantos, sem que sua conduta seja considerada violadora dos deveres de lealdade e cooperação processual, ou atentatória à boa-fé e aos bons costumes. Afinal, está em jogo o direito à liberdade do indivíduo, que prepondera, no caso concreto, sobre outros valores envolvidos. Lembre-se que, no processo penal, não litigam partes com interesses particulares e em igualdade de condições, mas sim o Estado, de um lado, com todo seu aparato repressor, e o réu, de outro, buscando se defender da acusação que lhe foi imputada e que pode redundar, no mais das vezes, na privação de sua liberdade.

É justamente em virtude dessa desigualdade entre os litigantes no processo penal que, entre outras coisas ${ }^{297}$, não se impõe ao imputado rígidos deveres de veracidade, de lealdade e de colaboração processual. Ao acusado é garantido, por exemplo, o direito ao silêncio (art. $5^{\circ}$, LXIII, da Constituição Federal), ou, mais amplamente, o direito a não produzir provas contra si mesmo ${ }^{298}$.

Tal direito está diretamente relacionado tanto ao já mencionado direito à ampla defesa como ao princípio da presunção de inocência, pois apenas num sistema em que esta é assegurada, o silêncio do acusado não é interpretado como prova nem gera presunção em seu desfavor ${ }^{299}$.

\footnotetext{
${ }^{297}$ Sobre outros direitos e garantias assegurados exclusivamente à defesa no processo penal, veja-se mais nas notas 192 e 193.

${ }^{298}$ A previsão do art. $5^{\circ}$, LXIII, da Constituição Federal de 1988, relativa ao direito do preso de permanecer calado, não pode ser interpretada restritivamente, sob pena de o preceito não atingir a finalidade para a qual foi concebido. Tem-se entendido, portanto, que o direito ao silêncio é assegurado não apenas aos acusados presos, mas também aos que se encontram soltos, e aos meros suspeitos/indiciados, além do que a prerrogativa garante tanto o direito de calar-se nos interrogatórios, como o de não produzir quaisquer provas contra si. Cf. MARTA SAAD, O direito de defesa no inquérito policial, São Paulo, Revista dos Tribunais, 2004, pp. 289-298. Sobre o assunto, acrescentam MARIA THEREZA ROCHA DE ASSIS MOURA e MAURÍCIO ZANÓIDE DE MORAES que "definir o direito ao silêncio como sendo, unicamente, o direito de calar ante as perguntas da autoridade competente (policial ou judiciária), no momento do interrogatório, é impor-lhe uma limitação que não condiz com as origens do instituto". Cf. Direito ao silêncio no interrogatório in Revista Brasileira de Ciências Criminais, $\mathrm{n}^{\circ}$ 6, São Paulo, Revista dos Tribunais, abriljunho de 1994, p. 138.

299 Ao tratar do tema, observa ANTONIO MAGALHÃES GOMES FILHO que o direito ao silêncio "representa exigência inafastável do processo penal informado pela presunção de inocência, pois admitir-se o contrário equivaleria a transformar o acusado em objeto da investigação, quando sua participação só pode ser entendida na perspectiva da defesa, como sujeito processual. Diante disso, evidente que seu silêncio jamais pode ser interpretado desfavoravelmente”. Cf. O princípio da presunção de inocência na
} 
O direito a não auto-incriminação é também conhecido pelo brocardo latino "nemo tenetur se detegere" 300 , e é um dos temas mais interessantes e polêmicos no âmbito da ciência processual penal, tanto que poderia, por si só, ser objeto de estudo específico. Para os fins deste trabalho, porém, importa ressaltar que tem prevalecido o entendimento de que o direito a não auto-incriminação engloba não apenas os direitos ao silêncio ou a não submissão a qualquer diligência probatória que implique a auto-acusação do imputado, mas também abrange o direito à mentira ${ }^{301}$.

$\mathrm{Na}$ doutrina brasileira, GUILHERME DE SOUZA NUCCI é um dos juristas que defende categoricamente a existência do direito à mentira. Segundo ele, "no exercício da sua autodefesa e para não incidir na auto-acusação, pode o acusado dizer o que bem entende, inclusive mentir. Se pode e deve defender-se com amplidão, é natural que o direito de faltar com a verdade esteja presente. Tanto assim que ele pode até incriminar outra pessoa para salvar-se, sem que seja punido. Essa mentira não é sancionada ${ }^{, 302}$.

\section{Já para MARIA ELIZABETH QUEIJO ${ }^{303}$ e GUSTAVO HENRIQUE}

RIGHI IVAHY BADARÓ, não existe propriamente um direito de mentir para o acusado,

Constituição de 1988 e na Convenção Americana sobre Direitos Humanos - Pacto de São José da Costa Rica in Revista da Associação dos Advogados de São Paulo, no 42, 1994, pp. 30-34.

${ }^{300}$ Há várias expressões em latim que denotam a mesma idéia: nemo tenetur se ipsum accusare (ninguém é obrigado a acusar a si mesmo), nemo contra se edere tenetur (ninguém é obrigado a se denunciar), nemo tenetur detegere propriam turpitudinem (ninguém é obrigado a declarar a própria torpeza), nemo testis contra se ipsum (ninguém testemunhe contra si mesmo). Cf. JOÃO CLAUDIO COUCEIRO, A garantia constitucional do direito ao silêncio, São Paulo, Revista dos Tribunais, 2004, p. 25.

${ }^{301}$ Para parte da doutrina, não existe direito à mentira no processo penal brasileiro. Ilustra tal corrente o posicionamento de ROMEU PIRES DE CAMPOS BARROS, para quem a mentira do acusado produz efeitos de direito substancial e de direito processual: "no primeiro aspecto, servirá como um indice da personalidade do acusado, que também, como objeto do processo, está sendo observado pelo seu julgador neste ato, podendo influir na medida da pena, quando esta venha a lhe ser imposta, atentas as condições previstas no art. 42 do Código Penal. E o efeito de direito processual resultará do comportamento do acusado como parte, o que poderá gerar presunções contrárias aos seus interesses na avaliação do conjunto das provas” Cf. Sistema do processo penal brasileiro, vol. I, Rio de Janeiro, Forense, 1987, p. 453.

${ }^{302}$ Cf. GUILHERME DE SOUZA NUCCI, $O$ valor da confissão como meio de prova no processo penal, São Paulo, Revista dos Tribunais, 1997, p. 86. No mesmo sentido posicionam-se MARTA SAAD, $O$ direito de defesa no inquérito policial, São Paulo, Revista dos Tribunais, 2004, p. 298, e THEODOMIRO DIAS NETO, $O$ direito ao silêncio: tratamento nos direitos alemão e norte-americano in Revista Brasileira de Ciências Criminais, nº 19, São Paulo, Revista dos Tribunais, julho-setembro de 1997, p. 187.

${ }^{303}$ Segundo a autora, “a eventual mentira e a reticência do acusado não poderão ser valoradas pelo juiz, como indícios de culpabilidade, porque nada mais são do que expressão do direito a não se autoincriminar". Cf. $O$ direito de não produzir prova contra si mesmo (o princípio nemo tenetur se detegere e suas decorrências no processo penal), São Paulo, Saraiva, 2003, p. 235. 
mas sim uma irrelevância jurídica em sua mentira, pois de tal ato não poderão lhe advir conseqüências negativas $^{304}$.

Na doutrina estrangeira, o jurista MIRJAN R. DAMASKA reconhece que o acusado é mais propenso a mentir do que a testemunha, pois visa a proteger seus interesses na causa. No entanto, ressalva o jurista que da garantia do direito à mentira podem advir conseqüências indesejáveis para o processo, pois os deveres de lealdade e de colaboração para a administração da Justiça deixam de ser observados ${ }^{305}$.

Seja como for, o fato é que, no Brasil, salvo na hipótese de auto-acusação falsa (crime do art. 341 do Código Penal, em que o indivíduo se acusa, perante a autoridade, de crime inexistente ou praticado por outrem), a mentira do acusado não é punível, apenas a das testemunhas configura crime contra a Administração da Justiça (art. 342 do Código Penal) ${ }^{306}$.

Como se vê, no processo penal não se pode impor ao imputado um rígido dever de veracidade, de lealdade e de colaboração processual, por conta dos princípios, direitos e garantias aplicáveis exclusivamente em tal esfera. E, no que diz respeito à acusação, lembre-se que a maioria das ações penais é de iniciativa pública, e tem como titulares o Parquet. Os membros desta instituição estatal estão obrigados a observar rígidos padrões de legalidade em sua atuação e, por isso, a princípio, não poderiam praticar atos processuais abusivos, até sob pena de responsabilização funcional.

Em outras palavras, o fato de a ação penal ser geralmente pública, por si só, já impede cogitar-se da prática de atos processuais abusivos pela acusação, por conta da presunção de legalidade de que se reveste a atuação do Ministério Público.

Diante do exposto, afigura-se praticamente impossível no sistema processual brasileiro sancionar condutas que caracterizem abuso do direito à investigação. A mera importação dos institutos relacionados à "abuse discovery" do direito norte-

\footnotetext{
${ }^{304}$ Acrescenta ainda o autor que "o direito ao silêncio do acusado inclui o direito de apresentar versão para encobrir fatos sobre os quais deseja se calar. Se o acusado atribui a outrem a autoria do crime que lhe é imputado, sabendo ser este inocente, não cometerá o crime de denunciação caluniosa, se o fizer para se defender. Porém, se o acusado mentir para confessar um crime que não cometeu, poderá responder pelo delito de auto-acusação falsa”. Cf. Direito processual penal, Tomo I, Rio de Janeiro, Elsevier, 2008, p. 233. ${ }^{305}$ Cf. I volti della giustizia e del potere - Analisi comparatistica del processo, Bologna, Il Mulino, 1991, pp. 221-222.

${ }^{306}$ Mencione-se que, no sistema da Common Law, diferentemente do que ocorre em nosso processo penal, o acusado pode renunciar ao direito a não auto-incriminação e, neste caso, tem o dever de dizer a verdade, sob pena de cometer perjúrio. Cf. ADA PELLEGRINI GRINOVER, Interrogatório do réu e direito ao silêncio in Ciência Penal, ano 3, n 1, São Paulo, Ed. Convívio, 1976, p. 24.
} 
americano, ou a aplicação, por analogia, das regras e sanções previstas no Código de Processo Civil pátrio relativas aos deveres das partes e às condutas que caracterizam litigância de má-fé, não se mostra viável, em face das particularidades existentes no processo penal, em que uma das partes é, no mais das vezes, uma instituição estatal que deve observar rígidos parâmetros de legalidade, e onde as garantias da ampla defesa e da presunção de inocência atenuam os deveres de lealdade, veracidade e colaboração processual do imputado, permitindo-lhe até mesmo mentir para não se auto-incriminar, sem que por isso lhe seja imposta qualquer sanção.

Sobre este assunto, vale destacar a opinião de CARLA SILENE CARDOSO LISBOA BERNARDO GOMES, para quem "o processo penal não contempla a possibilidade de condenação por litigância de má-fé, sendo vedada a aplicação subsidiária do Código de Processo Civil nessa parte, porque os princípios específicos deste não se coadunam com os princípios que regem o processo penal ${ }^{\text {’307 }}$. No mesmo sentido foram proferidas diversas decisões pelo C. Superior Tribunal de Justiça em tempos recentes $^{308}$.

É evidente, porém, que o direito à investigação, como todo direito, não é absoluto, e por isso mesmo seu exercício deve se dar dentro de certos limites, sob pena de violar outros direitos e garantias igualmente assegurados. Por certo não se pode utilizar meios de investigação de prova, ou produzir provas cautelares e antecipadas, ilícitas no bojo de uma instrução preliminar. Não são permitidas, por exemplo, escutas ou interceptações telefônicas que desatendam aos parâmetros legais, tampouco a realização de outros atos instrutórios que impliquem violação de sigilo, intimidade ou privacidade. Lembre-se que a inadmissibilidade das provas ilícitas é assegurada pela Constituição Federal de 1988, em seu art. 5º, LVI.

Do mesmo modo, devem os titulares do direito à investigação procurar se abster de realizar diligências com fins escusos, apenas para prejudicar a parte contrária, acarretando-lhe despesas excessivas, criando óbices desnecessários à sua atuação ou retardando sua instrução preliminar. Lembre-se que o abuso de direito processual não é punível na seara criminal apenas para que os seus princípios informadores sejam

\footnotetext{
${ }^{307}$ Cf. Inexistência de multa por litigância de má-fé no processo penal in Análise de precedentes criminais do Superior Tribunal de Justiça - Estudos em homenagem à Desembargadora Jane Ribeiro Silva, Belo Horizonte, Ed. Atualizar, 2009, p. 86.

${ }^{308}$ Cf. STJ, APn 477/PB, Rel. Min. Eliana Calmon, Corte Especial, j. 04.03.2009, STJ, HC 117.320/SC, Rel. Min. Jane Silva, Sexta Turma, j. 02.12.2008, entre outros.
} 
preservados. Se restar demonstrado que referidas condutas abusivas em matéria probatória não se deram no escopo de resguardar a ampla defesa ou a presunção de inocência, ou extrapolaram os limites legais impostos à atuação ministerial, cabível cogitar-se da aplicação de eventual sanção neste sentido.

Ressalte-se, porém, que a imposição de penalidades para tais atos abusivos seria igualmente problemática na hipótese acima, pela dificuldade de comprovação do exercício do direito à investigação para finalidade escusa, e mesmo de apuração do responsável pelos excessos cometidos, no caso das instruções preliminares particulares (parte ou advogado).

Esta dificuldade de sancionar adequadamente o abuso do direito à investigação é também verificada no processo penal italiano, não obstante a minuciosa disciplina jurídica existente no país sobre o assunto ${ }^{309}$.

Em suma, parece recomendável que o tratamento do abuso do direito à investigação no processo penal brasileiro se dê casuisticamente, em face do ordenamento jurídico vigente. Não é possível afirmar, aprioristicamente, quais condutas podem configurar abuso de direito em matéria de investigação, principalmente por conta das peculiaridades que distinguem o processo penal do cível. Logo, as circunstâncias de cada caso concreto deverão ser analisadas para apuração de eventual prática de ato de instrução preliminar abusivo, com todas as conseqüências daí advindas. Não tem sido admitida, por exemplo, a imposição por analogia das penas por litigância de má-fé do processo civil ao processo penal, mas é possível cogitar-se da aplicação de outras sanções, como a inadmissibilidade de meios de investigação de prova, e de provas cautelares e antecipadas, ilícitas, e mesmo a responsabilização do profissional incumbido da investigação, nas esferas cabíveis, quando demonstrado o excesso.

\subsubsection{Divulgação pela mídia das informações obtidas através das} investigações criminais

Neste ponto, afigura-se oportuno fazer uma breve digressão acerca dos possíveis usos pela imprensa das informações relativas às investigações criminais. É sabido que o cometimento de crimes, muitas vezes, desperta grande atenção da opinião pública,

${ }^{309}$ Cf. ELENA MARIA CATALANO, L'abuso del processo, Milano, Giuffrè, 2004, e ANDRÉ AUGUSTO MENDES MACHADO, Investigação criminal defensiva, São Paulo, Revista dos Tribunais, 2010, pp. 163166. 
seja por sua gravidade, seja pelas vítimas atingidas, seja pelas peculiares circunstâncias que os cercam.

Natural, portanto, que os meios de comunicação apresentem interesse em noticiar a prática de delitos. Ocorre, porém, que comumente a imprensa o faz de maneira não comedida, relatando os fatos em tom sensacionalista, tratando os suspeitos como se condenados fossem, em evidente afronta ao princípio da presunção de inocência, ou então prejudicando as investigações oficiais quando acaba com o elemento surpresa, essencial a determinadas diligências.

Ressalte-se que a sociedade atual, massificada, vive numa era de grande desenvolvimento tecnológico, de modo que a veiculação de qualquer notícia pelo rádio, televisão ou Internet, meios de comunicação instantâneos, pode atingir milhares de pessoas em segundos. Em se tratando da notícia do cometimento de um delito, dependendo da maneira pela qual for transmitida, pode imprimir a pecha de provável culpado a um indivíduo que, mesmo sendo considerado inocente ao término da investigação ou do processo, já terá sofrido uma série de estigmatizações e discriminações.

O jurista italiano FRANCESCO CARNELUTTI já chamava a atenção para as conseqüências negativas da própria condição de investigado pela prática de um delito, que adquirem repercussão ainda maior quando vêm a público: "O homem, quando sobre ele recai a suspeita de haver cometido um delito, é dado às bestas, como se dizia no tempo dos condenados oferecidos como pasto às feras. A fera, a indomável e insaciável fera, é a multidão. (...) Apenas é surgida suspeita, o imputado, sua família, sua casa, seu trabalho, são inquiridos, requeridos, examinados, desnudados, na presença de todo mundo. $O$ indivíduo, desta maneira, é convertido em pedaços. E o indivíduo, recorde-se, é o único valor que deveria ser salvo pela civilização" ${ }^{\text {310. }}$.

Ainda sobre o assunto, ADAUTO SUANNES salienta o fato de que a divulgação, pela imprensa, do nome de um indivíduo suspeito da prática de um crime

\footnotetext{
${ }^{310}$ Cf. Las miserias del proceso penal, trad. S. S. Melendo, Editorial Temis S.A., Bogotá, 1989, pp. 48-49. O trecho foi traduzido livremente do seguinte: "El hombre, cuando sobre él recae la sospecha de haber cometido un delito, es dado ad bestias, como se decía en un tiempo de los condenados ofrecidos como pasto a las fieras. La fiera, la indomable e insaciable fiera, es la multitud. (...) Apenas ha surgido la sospecha, el imputado, su familia, su casa, su trabajo, son inquiridos, requeridos, examinados, desnudados, a la presencia de todo el mundo. El individuo, de esta manera, es convertido em pedazos. Y el individuo, recordémoslo, es el único valor que debería ser salvado por la civilidad".
} 
como sendo seu autor viola, mais do que o princípio da presunção de inocência, o da dignidade da pessoa humana ${ }^{311}$.

E, como já dito, a divulgação descuidada ou precipitada de informações pela imprensa acerca do rumo das investigações pode prejudicar não apenas o imputado, mas também a própria efetividade da instrução preliminar, como quando leva ao conhecimento antecipado das diligências a serem realizadas, comprometendo o elemento surpresa necessário ao êxito de determinados meios de investigação de provas.

Não se objetiva aqui efetuar uma profunda análise acerca da correlação entre investigações criminais e seu tratamento pela mídia, tema este que, por sua amplitude e importância, é suscetível de estudo específico ${ }^{312}$. Objetiva-se, neste momento, apenas trazer à tona as discussões concernentes ao uso por terceiros, em especial os veículos de comunicação, dos elementos informativos colhidos em instruções criminais prévias.

É importante salientar que a veiculação pelos meios de comunicação de fatos relacionados às investigações criminais envolve o conflito entre diferentes direitos fundamentais: o direito à liberdade de imprensa, ao acesso à informação, à vida privada, $\mathrm{e}$ à publicidade dos atos administrativos e jurisdicionais, ainda que mitigada pelo sigilo das investigações em certas hipóteses ${ }^{313}$.

Como bem observa NEREU JOSÉ GIACOMOLLI, o problema muitas vezes não reside na veiculação em si de informações a respeito de um crime, mas sim no modo como se transmite a notícia. Segundo o autor, "a incongruência situa-se justamente na publicidade extrema, abusiva, mormente a efetivada pela mídia, através da divulgação de imagens, nomes completos, endereços, atividades profissionais de meros suspeitos da prática de ilícitos, antecipatória de processos, de condenação e de pena, além da estigmatização. A manipulação da situação - pena, julgamento, encarceramento, algemas, etc. - passou a servir de material fértil à manutenção dos índices de audiência de programas de rádio e televisão, em suma, de fonte de lucro, quiçá pelo sabor do

\footnotetext{
${ }^{311}$ Cf. Os Fundamentos éticos do devido processo penal, São Paulo, Revista dos Tribunais, 1999, p. 159.

${ }^{312} \mathrm{O}$ assunto já foi alvo de análise aprofundada pela jurista ANA LÚCIA MENEZES VIEIRA in Processo penal e mídia, São Paulo, Revista dos Tribunais, 2003.

${ }^{313}$ Cf. ANA LÚCIA MENEZES VIEIRA, Processo penal e mídia, São Paulo, Revista dos Tribunais, 2003, p. 208.
} 
escândalo, de certo movimento de tragédia e de certo emergir reprodutor da miséria humana, soterrada, escondida, entranhada, olvidada" ${ }^{\text {314. }}$.

A jurista ANA LÚCIA MENEZES VIEIRA lembra que a aplicação do princípio da proporcionalidade permite que um dos valores envolvidos na veiculação de notícias sobre crimes se sobreponha aos demais no caso concreto, e aponta uma série de alternativas propostas pela doutrina para a melhor ponderação entre os princípios acima referidos: ausência total de controle para a mídia, com mera reparação civil nas hipóteses de publicações violadoras de direitos da personalidade, autocontrole da imprensa, que dependeria de maturidade jornalística dos meios de comunicação, além de educação da população em nível tal que lhe permitisse ter visão crítica das notícias que lhe são repassadas, ou mesmo através da edição de normas que limitem a divulgação de informações relativas a investigações ou processos penais, solução esta que não esbarraria em qualquer óbice constitucional, diante da possibilidade de restringir a liberdade de imprensa para assegurar outros bens jurídicos de igual valor ${ }^{315}$.

Também para HELENA NAJJAR ABDO os direitos e princípios concernentes à veiculação de informações processuais pela imprensa podem ser conciliados. O direito de informar, que atende ao princípio da publicidade mediata (indireta), pode ser exercido sem implicar violação à privacidade dos envolvidos, bastando para tanto que observe a regra de objetividade. Tal regra serve como limite à publicidade do processo, e impõe o seguinte método de trabalho aos meios de comunicação: selecionar as informações a serem veiculadas com base no interesse público, cuidar para que o conteúdo da notícia seja verdadeiro, e transmiti-la sem quaisquer juízos de valores ou observações de cunho subjetivo ${ }^{316}$.

Como já ressalvado, por se tratar de tema complexo e abrangente, a comunicação pela imprensa dos atos processuais, e mais especificamente dos atos de

\footnotetext{
${ }^{314}$ Cf. A fase preliminar do processo penal-Crises, misérias e novas metodologias investigatórias, Rio de Janeiro, Lumen Juris, 2011, pp. 60-61. Prossegue ainda o autor, afirmando que "as investigações passaram a receber estranhas denominações, na linha do entretenimento popular e da sustentação econômica da mídia: operação satiagraha, operação cupim, operação guilhotina, operação jurupari, operação visconde, etc. Muitas foram as críticas acerca da aproximação a um verdadeiro espetáculo cinematográfico, transmitido on line, com divulgação impactante de interceptações telefônicas, de imagens, som, troca de tiros, homens vestidos à moda ninja, embates, prisões ao vivo, frotas de veículos com sirenes ligadas, gritos e aplausos histéricos. O resultado é a confusão entre opinião pública e publicada, a degeneração do processo penal, bem como o desvirtuamento da atividade de informar".

${ }^{315}$ Cf. Processo penal e mídia, São Paulo, Revista dos Tribunais, 2003, pp. 259-262.

316 Cf. Observância da regra da objetividade na publicidade do processo realizada pelos meios de comunicação social, Tese de Doutorado apresentada à Faculdade de Direito da Universidade de São Paulo em 2006, p. 245.
} 
investigação criminal, deve ser (e tem sido) objeto de análises aprofundadas e específicas. O presente trabalho se dedica essencialmente ao estudo da investigação como direito das partes, decorrente do direito à prova, e das repercussões práticas do reconhecimento de tal direito em nosso ordenamento jurídico.

Todavia, na análise dos possíveis usos das informações colhidas no seio das investigações, não se poderia deixar de mencionar que terceiros estranhos ao procedimento, mais precisamente os meios de comunicação, também se valem desses informes no exercício de suas atividades.

Aqui se buscou apenas chamar a atenção para os riscos ao investigado e à própria investigação da atuação descuidada e excessiva da imprensa ao noticiar os fatos criminosos e suas circunstâncias, salientando que a doutrina tem apontado diversas soluções para que os princípios e valores concernentes ao tema restem assegurados no caso concreto. 


\section{CAPÍTULO III - DIREITO À INVESTIGAÇÃO: BREVE ANÁLISE DE DIREITO COMPARADO}

\subsection{CONSIDERAÇÕES INICIAIS}

Nos capítulos anteriores, buscou-se estabelecer as premissas teóricas necessárias à compreensão do direito à investigação em sua completude, com ligeiras incursões no direito comparado. Isto porque o estudo da investigação como direito das partes decorrente do direito à prova gerava a necessidade de análise tanto de seu conteúdo, como de sua natureza jurídica, de sua titularidade e dos modos pelos quais tal direito pode ser exercitado, mas não apenas: a admissibilidade do direito à investigação também exigia perquirir sobre as possíveis destinações das informações obtidas nessa fase da persecução penal.

Vistos, pois, os principais aspectos teóricos relacionados ao direito à investigação, é chegado o momento de examinar com maior atenção o tratamento conferido pelos diferentes sistemas processuais à matéria. Essa análise de direito comparado, ainda que perfunctória - uma vez que não se trata do objeto central deste estudo -, permitirá conhecer como os países têm lidado com o tema, e avaliar as vantagens e inconvenientes de cada um dos regramentos perfilhados.

Nesse sentido, mostra-se imperioso verificar qual foi o modelo de investigação criminal adotado pelos ordenamentos analisados, já que tal escolha repercute diretamente sobre os modos através dos quais o direito à investigação pode ser exercido pelas partes. Aliás, um dos critérios mais utilizados para classificar os diferentes sistemas de investigação criminal é justamente o do sujeito responsável por sua realização. Num sistema de investigação ministerial, por exemplo, por óbvio que ao Parquet é assegurado o direito à investigação, o que permite cogitar da atribuição de tal direito também à defesa, até para fins de garantia da igualdade e da paridade de armas. Já nos sistemas de investigação policial e do juizado de instrução, o direito à investigação encontra maiores dificuldades de reconhecimento.

Neste ponto, é importante mencionar que, na maioria dos países, a instrução preliminar não é atribuída exclusivamente a determinado órgão ou instituição, o que se explica, entre outros fatores, pelo próprio reconhecimento do direito à investigação das 
partes. Mas, levando em consideração o sujeito a quem foi incumbida precipuamente a função de realizar investigações criminais, costuma-se dividir os sistemas de instrução prévia ou preparatória em três categorias: juizado de instrução, investigação policial e investigação ministerial. A análise de cada uma dessas modalidades permitirá verificar, em linhas gerais, como o direito à investigação é tratado nos mais diferentes países.

\subsection{DIREITO À INVESTIGAÇÃO NOS DIFERENTES SISTEMAS DE INVESTIGAÇÃO CRIMINAL}

\subsubsection{Juizado de instrução}

Em linhas gerais, é possível afirmar que, no juizado de instrução, a investigação criminal é atividade atribuída essencialmente a um magistrado dito instrutor. Este sistema era típico dos sistemas processuais penais inquisitórios, nos quais o juiz reunia as funções de investigar, acusar e julgar ${ }^{317}$, mas subsiste até hoje em países que adotaram o sistema acusatório.

Entre os atos praticáveis pelo juiz no exercício desse mister, AURY LOPES JR. elenca os seguintes: interrogatório do investigado, determinação de medidas cautelares ou reais, concessão de liberdade provisória, designação de defensor para o investigado, realização de inspeções judiciais, determinação de perícias, reconhecimento de pessoas e coisas, oitiva de testemunhas, entre outras ${ }^{318}$.

Saliente-se que a busca de elementos de convicção é feita pessoalmente pelo magistrado, e não apenas na sua presença, sendo possível, porém, o auxílio de órgão administrativo, via de regra a polícia, para a realização de determinadas diligências ${ }^{319}$.

Neste sistema, o juiz geralmente inicia de ofício a instrução preliminar, procedendo aos atos de investigação que julgar mais convenientes e valorando-os conforme seu convencimento, sem vincular-se a qualquer dos envolvidos no procedimento (acusação ou defesa).

317 Cf. MARCOS ALEXANDRE COELHO ZILLI, A iniciativa instrutória do juiz no processo penal, São Paulo, Revista dos Tribunais, 2003, p. 39.

${ }^{318}$ Cf. Sistemas de investigação preliminar no processo penal, Rio de Janeiro, Lumen Juris, 2001, pp. 64-65.

319 Cf. NEREU JOSÉ GIACOMOLLI, A fase preliminar do processo penal - Crises, misérias e novas metodologias investigatórias, Rio de Janeiro, Lumen Juris, 2011, p. 28. 
Entre as vantagens apresentadas pela adoção do juizado de instrução estaria a maior credibilidade dos resultados da investigação, já que esta é conduzida por uma autoridade estatal que se sobrepõe às partes ${ }^{320}$, a desnecessidade de interferência de outro sujeito no deferimento de medidas cautelares ${ }^{321}$, além do que, ao menos em tese, fica afastada eventual tendência de colheita de elementos que favoreçam mais à acusação que à defesa, ou vice-versa.

Todavia, o regime apresenta alguns sérios inconvenientes, entre os quais o fato de remeter aos sistemas processuais penais inquisitórios, e a irrazoabilidade de uma única autoridade decidir pela realização de determinados atos investigatórios e também valorá- $\operatorname{los}^{322}$. Ademais, corre-se o risco de os elementos colhidos na etapa investigatória servirem como prova na fase processual, sem que tenham sido produzidos com observância ao contraditório e à ampla defesa ${ }^{323}$.

Como já adiantado, embora característico dos sistemas inquisitórios, o juizado de instrução também se faz presente em sistemas acusatórios na atualidade, a exemplo da França e da Espanha.

\subsubsection{França}

Neste país, a despeito de a investigação ficar a cargo do juiz instrutor, o Ministério Público também apresenta papel importante na fase inicial da persecução penal, sendo atribuição de seus representantes o recebimento das notícias do cometimento de infrações penais e sua correta classificação em crimes, delitos ou contravenções, através de breve investigação (enquête préliminaire). Se o fato típico configurar crime ou delito mais grave, deve o Parquet meramente encaminhar a notícia ao juiz de instrução, a quem incumbirá presidir a instrução preparatória. Este magistrado dirige as investigações,

\footnotetext{
${ }^{320}$ Cf. AURY LOPES JR., Sistemas de investigação preliminar no processo penal, Rio de Janeiro, Lumen Juris, 2001, p. 73.

${ }^{321}$ Cf. NEREU JOSÉ GIACOMOLLI, A fase preliminar do processo penal - Crises, misérias e novas metodologias investigatórias, Rio de Janeiro, Lumen Juris, 2011, p. 29.

${ }^{322}$ Cf. AURY LOPES JR., Sistemas de investigação preliminar no processo penal, Rio de Janeiro, Lumen Juris, 2001, p. 76.

${ }^{323}$ Cf. NEREU JOSÉ GIACOMOLLI, A fase preliminar do processo penal - Crises, misérias e novas metodologias investigatórias, Rio de Janeiro, Lumen Juris, 2011, p. 29.
} 
ouvindo testemunhas e suspeitos, realizando constatações materiais ${ }^{324}$ e determinando quais diligências deverão ser feitas pela polícia ou outros órgãos, como peritos ${ }^{325}$.

De outro lado, se o delito for de menor gravidade e complexidade, a investigação fica a cargo do Ministério Público, que é auxiliado pela polícia em tal atividade, sendo oportuno mencionar que, assim como na Itália, na França os membros do Parquet também são considerados magistrados, pois integram tanto como os juízes de instrução o Poder Judiciário ${ }^{326}$.

Como se vê, na França o direito à investigação é conferido ao menos ao órgão da acusação (em certas hipóteses, vale ressaltar), mesmo sendo incumbência do juiz instrutor, com o auxílio da polícia, a realização da instrução preliminar.

\subsubsection{Espanha}

Neste país, a fase pré-processual também é dominada pela figura do juiz instrutor, mas o sistema apresenta certa complexidade, pois há três diferentes tipos de instrução preliminar, quais sejam sumario, diligencias previas e instrucción complementaria $^{327}$. A determinação da espécie de instrução depende do rito processual previsto para cada tipo de delito e de qual órgão é incumbido da investigação, pois se o sumario é o modelo de instrução judicial por natureza, as diligencias previas são atribuídas essencialmente ao Ministério Público ${ }^{328}$.

Mas também no modelo espanhol a polícia atua como órgão auxiliar nas investigações, realizando diligências e atos preparatórios necessários à propositura da ação penal $^{329}$.

Nota-se, portanto, que o direito à investigação também é reconhecido ao órgão da acusação na Espanha, ainda que de forma restrita. Quanto à defesa, não há

\footnotetext{
${ }^{324}$ Cf. JACOBO LÓPEZ BARJA DE QUIROGA, Tratado de derecho procesal penal, Navarra, Aranzadi, 2004 , p. 705.

${ }^{325}$ Cf. DENISE NEVES ABADE, Garantias do processo penal acusatório - O novo papel do Ministério Público no processo penal de partes, Rio de Janeiro, Renovar, 2005, pp. 41-44.

${ }^{326}$ Cf. AURY LOPES JR., Sistemas de investigação preliminar no processo penal, Rio de Janeiro, Lumen Juris, 2001, pp. 217-218.

${ }^{327}$ Cf. VINÍCIO STEIN CAMPOS, A força dos grupos de pressão sobre a proposta de mudanças na investigação criminal, na reforma do processo penal brasileiro in Revista A Força Policial, nº 60, São Paulo, outubro-dezembro de 2008, p. 28.

${ }^{328}$ Cf. AURY LOPES JR., Sistemas de investigação preliminar no processo penal, Rio de Janeiro, Lumen Juris, 2001, pp. 204-205.

${ }^{329}$ Cf. DENISE NEVES ABADE, Garantias do processo penal acusatório - O novo papel do Ministério Público no processo penal de partes, Rio de Janeiro, Renovar, 2005, p. 49.
} 
reconhecimento legal expresso de tal direito, mas há uma tendência cada vez maior de permitir sua participação na fase instrutória prévia. O próprio código de processo penal local exige a intimação prévia do defensor do investigado para a realização de certas diligências, e mesmo para a produção de prova antecipada ${ }^{330}$.

Aliás, os tribunais espanhóis também têm discutido a constitucionalidade das provas produzidas por detetives privados, sendo possível perceber certa inclinação da jurisprudência e de alguns juristas espanhóis no sentido de admitir tais provas em juízo, desde que preenchidos certos requisitos, como a observância ao contraditório, ainda que diferido $^{331}$.

\subsubsection{Investigação policial}

No modelo de investigação policial, é a polícia judiciária o órgão incumbido de promover os atos necessários à apuração das principais circunstâncias relativas ao delito.

Vale observar que, neste modelo, a polícia não é mera auxiliar de outro órgão a quem é efetivamente atribuída a função investigatória, e sim a instituição legalmente responsável pela promoção da instrução preliminar, tendo, por este motivo, discricionariedade em sua atuação. Nesse sentido, pode realizar as diligências que reputar necessárias, e na forma que entender mais adequada, desde que, observe, evidentemente, o princípio da legalidade que pauta sua atuação ${ }^{332}$.

Apenas para a realização de diligências que importem restrição a direitos fundamentais exige-se autorização judicial, funcionando o magistrado, na hipótese, como

\footnotetext{
${ }^{330}$ Cf. ANTONIO SCARANCE FERNANDES, Reação defensiva à imputação, São Paulo, Revista dos Tribunais, 2002, p. 119.

${ }^{331}$ Veja-se mais a respeito do tema em ELIA PÉREZ HERNÁNDEZ, La constitucionalidad de las pruebas aportadas por los detectives privados in Poder Judicial, n 35, setembro de 1994, pp. 225-260.

332 Sobre o assunto, explica ODETE MEDAUAR que "a discricionariedade significa uma condição de liberdade, mas não liberdade ilimitada; trata-se de liberdade onerosa, sujeita a vínculo de natureza peculiar. É uma liberdade-vínculo. Só vai exercer-se com base na atribuição legal, explícita ou implícita, desse poder especifico a determinados órgãos ou autoridades. Por outro lado, o poder discricionário sujeita-se não só às normas específicas para cada situação, mas a uma rede de princípios que asseguram a congruência da decisão ao fim de interesse geral e impedem seu uso abusivo". Cf. Direito administrativo moderno, $9^{a}$ ed., São Paulo, Revista dos Tribunais, 2005, pp. 126-127.
} 
"garantidor da legalidade das medidas investigatórias tomadas contra e a favor do suspeito "333.

Costuma-se apontar como vantagens do modelo de investigação policial a maior efetividade das investigações decorrente da proximidade da instituição com os cidadãos, a disponibilidade de instrumentos mais adequados para a realização de diligências, menor custo financeiro ao Estado, entre outros ${ }^{334}$.

Por outro lado, há diversos argumentos contrários à instrução preliminar efetuada pela polícia, um deles o risco de sua atuação discricionária se tornar arbitrária, ou mesmo a maior vulnerabilidade da instituição às pressões políticas e midiáticas ${ }^{335}$, bem como a morosidade, a má qualidade ${ }^{336}$ e, por conseguinte, a ineficiência ${ }^{337}$ das investigações levadas a cabo pela polícia.

Adotam este modelo de instrução preliminar, por exemplo, a Inglaterra e os Estados Unidos, países da Common Law, que, por isso mesmo, apresentam inúmeras diferenças em relação aos sistemas jurídicos dos países da Civil Law.

\subsubsection{Estados Unidos}

Como já dito, neste país é a polícia a entidade responsável pelas investigações criminais $^{338}$. No entanto, o Ministério Público atua conjuntamente com o órgão policial nessa atividade: as diligências pelo último realizadas são destinadas aos membros do Parquet, os quais, na esfera federal, também podem investigar delitos ${ }^{339}$.

A propósito, oportuno mencionar algumas características do sistema norteamericano que o diferenciam bastante do nosso: lá vige o princípio da oportunidade da

${ }^{333}$ Cf. FAUZI HASSAN CHOUKR, Garantias constitucionais na investigação criminal, $2^{\mathrm{a}}$ ed., Rio de Janeiro, Lumen Juris, 2001, p. 45.

334 Cf. NEREU JOSÉ GIACOMOLLI, A fase preliminar do processo penal - Crises, misérias e novas metodologias investigatórias, Rio de Janeiro, Lumen Juris, 2011, p. 27.

${ }^{335}$ Cf. MARCELA DE JESUS BOLDORI FERNANDES, A legitimidade investigativa do Ministério Público e a importância de sua investigação no combate ao crime organizado in Boletim Científico ESMPU, ano III, $\mathrm{n}^{\mathrm{o}}$ 2, Brasília, ESMPU, abril-junho de 2004, p. 53.

${ }^{336}$ Cf. ANTONIO SCARANCE FERNANDES, O equilibrio na investigação criminal in Estudos em Homenagem à Professora Ada Pellegrini Grinover, coord. Flávio Luiz Yarshell e Maurício Zanóide de Moraes, São Paulo, DPJ Editora, 2005, p. 325.

${ }^{337}$ Cf. VALTER FOLETO SANTIN, O Ministério Público na investigação criminal, Bauru, Edipro, 2001, p. 239.

${ }^{338}$ Cf. NEREU JOSÉ GIACOMOLLI, A fase preliminar do processo penal - Crises, misérias e novas metodologias investigatórias, Rio de Janeiro, Lumen Juris, 2011, pp. 26-27.

${ }^{339}$ Cf. DENISE NEVES ABADE, Garantias do processo penal acusatório - O novo papel do Ministério Público no processo penal de partes, Rio de Janeiro, Renovar, 2005, p. 30. 
ação penal, segundo o qual o órgão responsável pela acusação pode deixar de promover a ação penal por razões de conveniência (até econômica) ou falta de interesse público ${ }^{340}$, ao passo que no Brasil vigora, como regra, o princípio da obrigatoriedade da ação penal ${ }^{341}$.

O promotor americano também possui ampla liberdade para escolher os delitos que imputará ao infrator, o qual poderá receber várias acusações pelo mesmo fato, numa espécie de fragmentação da conduta delitiva para que fiquem configurados diversos crimes $^{342}$, e em esferas diferentes (estadual e federal) ${ }^{343}$. Aliás, o sistema federativo americano permite que os Estados disciplinem de maneiras diversas um mesmo tema, podendo ocorrer conflitos também entre os sistemas estaduais e o modelo federal ${ }^{344}$.

Outro importante diferencial do sistema americano reside no fato de que os promotores não ingressam na carreira através de concurso público, mas sim são eleitos, interessando, consequentemente, aos mesmos obter o maior número possível de condenações para conquistar a simpatia de seu eleitorado ${ }^{345}$.

Pois bem, nos EUA não apenas o direito à investigação do órgão da acusação é reconhecido em certa medida, mas também o direito à investigação da defesa. $\mathrm{Na}$ verdade, a possibilidade de promover investigações particulares encontra guarida há

\footnotetext{
${ }^{340}$ Os princípios da obrigatoriedade e da oportunidade da ação penal foram didaticamente conceituados por FLÚVIO CARDINELLE OLIVEIRA GARCIA: "o princípio da obrigatoriedade, também chamado de princípio da indisponibilidade ou da legalidade, é o que predomina no processo penal. Segundo ele, a autoridade policial é obrigada a instaurar Inquérito Policial e o órgão do Ministério Público não pode deixar de promover a ação penal quando houver a prática de um crime apurado mediante ação penal pública, conforme dispõem os artigos 5, 6 e 24 do CPP. Tal princípio contrapõe-se ao da oportunidade ou disponibilidade, pelo qual o órgão estatal tem a faculdade de promover ou não a ação penal, de acordo com a máxima minima non curat praetor, devendo o Estado abster-se de coisas insignificantes e, assim, deixar de promover o jus puniendi quando verificar, sob o prisma do interesse público, que do exercício da ação penal poderá advir maiores inconvenientes que vantagens". Cf. Formas alternativas de resolução de conflitos: uma abordagem no âmbito do direito penal e processual penal in Processo penal e garantias constitucionais, coord. Marco Antonio Marques da Silva, São Paulo, Quartier Latin, 2006, p. 281, nota 170.

${ }^{341}$ Para os crimes de menor potencial ofensivo, tem-se entendido que vige o princípio da discricionariedade regulada, através do qual o Ministério Público pode deixar de promover a ação penal, nas hipóteses previstas em lei. Sobre a compatibilidade entre o princípio da oportunidade da ação penal, inspirado na Common Law, e o nosso sistema processual penal, marcado pela indisponibilidade da ação penal por parte do Ministério Público, vejam-se os comentários de ANTONIO SCARANCE FERNANDES, O consenso na Justiça penal in Boletim do Instituto Brasileiro de Ciências Criminais, São Paulo, v. 7, n. 83, out. 1999, p. 15.

342 Cf. JANAÍNA CONCEIÇÃO PASCHOAL, Breves apontamentos relativos ao instituto do plea bargaining no direito norte-americano in Revista do curso de direito do Centro Universitário das Faculdades Metropolitanas Unidas, São Paulo, v. 15, n. 23, 2001, p. 118.

${ }^{343}$ Cf. FLÚVIO CARDINELLE OLIVEIRA GARCIA, Formas alternativas de resolução de conflitos: uma abordagem no âmbito do direito penal e processual penal in Processo penal e garantias constitucionais, coord. Marco Antonio Marques da Silva, São Paulo, Quartier Latin, 2006, p. 283.

${ }^{344}$ Cf. FAUZI HASSAN CHOUKR, Garantias constitucionais na investigação criminal, $2^{\mathrm{a}}$ ed., Rio de Janeiro, Lumen Juris, 2001, p. 72.

${ }^{345}$ Cf. FLÚVIO CARDINELLE OLIVEIRA GARCIA, Formas alternativas de resolução de conflitos: uma abordagem no âmbito do direito penal e processual penal in Processo penal e garantias constitucionais, coord. Marco Antonio Marques da Silva, São Paulo, Quartier Latin, 2006, p. 282.
} 
muito tempo nos Estados Unidos ${ }^{346}$, em virtude do próprio sistema adversarial vigente no país $^{347}$. Diferentemente do sistema inquisitorial, no qual a marcha processual recai preferencialmente sobre o juiz, no sistema adversarial, verificado principalmente nos países de origem anglo-saxã, às partes incumbe toda a responsabilidade pelo andamento processual e pela atividade instrutória ${ }^{348}$.

Logo, no sistema adversarial, as partes podem tanto investigar os fatos como produzir provas, sendo permitido também à defesa, por exemplo, inquirir testemunhas e consultar peritos, num modelo que prima por buscar a igualdade de oportunidades e limitações entre os adversários.

Neste ponto, observa MARCOS ALEXANDRE COELHO ZILLI que, como a acusação dispõe de todo um aparato de órgãos encarregados de concretizar a investigação que a defesa não detém, foram conferidas a esta certas prerrogativas, a fim de manter a igualdade entre as partes. Menciona o autor algumas dessas oportunidades concedidas ao imputado: "possibilidade de requisitar o comparecimento de testemunhas, obrigatoriedade da acusação em apresentar todas as provas que favoreçam o acusado, e liberdade de uso, pela defesa, de investigadores particulares" ${ }^{\text {349 }}$.

Oportuno ainda mencionar outra peculiaridade do sistema americano: as informações obtidas na investigação defensiva podem ser utilizadas como provas na fase judicial, desde que expressamente admitidas pelo Juiz na fase adjudicatória (a qual, na persecução penal, situa-se entre a fase investigatória e a judicial).

Como por conta disso exige-se da defesa na fase investigatória todos os requisitos necessários à obtenção de provas em Juízo, comumente opta-se por produzir as provas fora do processo para depois introduzi-las documentalmente nos autos, o que

\footnotetext{
${ }^{346}$ Cf. ANTONIO SCARANCE FERNANDES. Cf. Rumos da investigação criminal no direito brasileiro in Boletim do Instituto Manoel Pedro Pimentel, na 21, vol. 5, 2002, p. 13.

${ }^{347}$ Cf. ANDRÉ AUGUSTO MENDES MACHADO, Investigação criminal defensiva, São Paulo, Revista dos Tribunais, 2010, pp. 47-48.

${ }^{348}$ Cf. MARCOS ALEXANDRE COELHO ZILLI, A iniciativa instrutória do juiz no processo penal, São Paulo, Revista dos Tribunais, 2003, pp. 26-27. Neste ponto, não custa relembrar o que já foi dito acerca das confusões feitas entre as seguintes classificações do processo: acusatório/inquisitório e adversarial/inquisitorial. Como visto (item 2.1) estas categorias não se identificam: a primeira diz respeito, fundamentalmente, à existência ou não de atribuição a órgãos distintos das funções de acusar, defender e julgar, ao passo que a segunda refere-se, em síntese, ao grau de iniciativa probatória e de responsabilidade pelo andamento do processo concedido às partes e ao juiz. Logo, um processo acusatório pode ser regido tanto pelo sistema adversarial como pelo inquisitorial.

${ }^{349}$ Cf. A iniciativa instrutória do juiz no processo penal, São Paulo, Revista dos Tribunais, 2003, p. 48.
} 
também se deve à onerosidade da Justiça Criminal americana ${ }^{350}$. Imperioso, no entanto, ressaltar uma vez mais que a introdução no processo de elementos de informação colhidos na fase de investigação criminal deve observar regras e parâmetros rígidos, a fỉm de que esta etapa inicial da persecução penal não se torne a fase instrutória em si do processo $^{351}$.

Mas não há previsão de um procedimento rígido para a realização da investigação defensiva, devem ser observadas apenas as diretrizes gerais estabelecidas pela Constituição americana, e os precedentes dos tribunais concernentes à matéria, o que é, aliás, bastante característico desse sistema ${ }^{352}$.

\subsubsection{Inglaterra}

Neste país, o sistema processual penal é tão peculiar que não há nem mesmo um órgão de acusação estatal similar ao Ministério Público ${ }^{353}$, de modo que todas as tarefas relacionadas à investigação criminal, e à persecução penal como um todo, recaem sobre a polícia $^{354}$.

\footnotetext{
${ }^{350}$ Cf. ANDRÉ AUGUSTO MENDES MACHADO, Investigação criminal defensiva, São Paulo, Revista dos Tribunais, 2010, p. 126.

${ }^{351}$ Nesse sentido, muito pertinentes são as observações de ENNIO AMODIO, que, após minuciosa análise do ordenamento jurídico americano, asseverou que "as provas reais, frutos das buscas e apreensões efetuadas na fase anterior à do julgamento, podem fazer parte do material probatório utilizável pelo promotor, desde que tenham sido obtidas em observância às regras ditadas pela Quarta Emenda para tutelar a inviolabilidade domiciliar. A regra do "law of evidence", elaborada pela tradição da Common Law para assegurar a oralidade do julgamento e evitar o errôneo convencimento dos jurados, e o sistema das regras de exclusão ("exclusionary rules"), criado pela Suprema Corte para estimular a polícia a respeitar os direitos constitucionais do cidadão em investigações criminais, constituem uma barreira que impede o órgão da acusação de dar às investigações anteriores à fase de julgamento incontestável dignidade probatória". Eis o trecho, no idioma original: "Le prove reali, frutto delle perquisizioni e dei sequestri compiuti nella fase pretrial, in tanto possono entrare a far parte del materiale probatorio utilizzabile dal prosecutor, in quanto siano state raccolte nel rispetto delle norme dettate dal IV Emendamento a tutela della libertà domiciliare. Il diritto delle prove penali (law of evidence), elaborato della tradizione di common law per garantire l'oralità del dibattimento e prevenire l'erroneo convincimento dei giurati, e il sistema delle exclusionary rules, creato dalla U. S. Supreme Court per indurre la polizia a rispettare $i$ diritti costituzionali del cittadino nelle investigazioni penali, costituiscono una barriera che impedisce all'organo dell'accusa di dare alle indagini della fase pretrial incontestabili dignità probatoria". Cf. Il processo penale negli Stati Uniti d'America, Milano, Giuffrè Editore, 1988, p. XXXVII.

${ }^{352}$ Cf. ANDRÉ AUGUSTO MENDES MACHADO, Investigação criminal defensiva, São Paulo, Revista dos Tribunais, 2010, p. 127.

${ }^{353}$ Cf. EDUARDO LUIZ SANTOS CABETTE, O papel do inquérito policial no sistema acusatório - o modelo brasileiro in Revista Brasileira de Ciências Criminais, $n^{\circ}$ 35, São Paulo, Revista dos Tribunais, julhosetembro de 2001, p. 190.

${ }_{354}$ Cf. FAUZI HASSAN CHOUKR, Garantias constitucionais na investigação criminal, $2^{\mathrm{a}}$ ed., Rio de Janeiro, Lumen Juris, 2001, pp. 71-72.
} 
Aliás, o órgão policial inglês também nem sempre apresenta caráter estatal, o que torna possível a participação da sociedade civil organizada ou do ofendido pelo delito na persecução penal ${ }^{355}$.

Devido às enormes disparidades havidas entre este sistema e o nosso, inspirado no modelo continental europeu, o mesmo não será objeto de maiores considerações.

\subsubsection{Investigação ministerial}

Finalmente, no modelo da investigação ministerial, a promoção da instrução preliminar fica a cargo do Ministério Público, que pode realizar diretamente os atos investigatórios através de seus promotores ou direcionar a investigação realizada pela polícia. Na primeira hipótese, os membros do Parquet colhem eles próprios os elementos de informação através da oitiva de testemunhas, realização de diligências fora dos gabinetes e demais medidas cabíveis ${ }^{356}$. Na segunda, a promoção efetiva dos atos investigatórios cabe à polícia, que assume então função auxiliar na instrução, cumprindo meramente as determinações do Parquet ${ }^{357}$, tanto que os policiais, por estarem vinculados àquelas, não têm autonomia para contestá-las, estando sujeitos a sanções disciplinares caso não as cumpram.

Importante ressaltar que não se trata de mero controle da atividade policial pelo Ministério Público, como pode acontecer nos sistemas de investigação policial, uma

355 Cf. EDUARDO LUIZ SANTOS CABETTE, O papel do inquérito policial no sistema acusatório - o modelo brasileiro in Revista Brasileira de Ciências Criminais, $\mathrm{n}^{\mathbf{0}}$ 35, São Paulo, Revista dos Tribunais, julhosetembro de 2001, p. 190.

${ }^{356}$ Sobre o assunto, afirma MARCELLUS POLASTRI LIMA que "exercendo o Parquet a investigação se posiciona na situação de autoridade administrativa, já que, aqui, não é parte, como no processo penal, e, ao encarregar-se de apuração de infração penal, através de colheita de provas, pode o Ministério Público praticar uma gama variada de atos", estando sujeito, todavia, "a controle de legalidade, podendo inclusive, ser considerado autoridade coatora para fins de habeas corpus e mandado de segurança”. Cf. O Ministério Público pode ou não investigar? Uma análise de recente decisão do STF, in Revista Brasileira de Ciências Criminais, n 46, São Paulo, Revista dos Tribunais, janeiro-fevereiro de 2004, pp. 377-378.

${ }^{357}$ O sistema de investigação ministerial dificilmente é encontrado em sua forma "pura", por assim, dizer, nos países que encarregam o Parquet de promover as investigações criminais. Geralmente, os promotores não são os únicos a investigar os delitos em tais ordenamentos, pois contam com o auxílio da polícia, a qual, porém, costumeiramente lhe é subordinada. A esse respeito, observa ainda FAUZI HASSAN CHOUKR que, nesses países "não se perde a noção da importância do papel policial ao longo da fase preparatória da ação penal, nem o fato óbvio de que a policia desenvolve a primeira atividade cognitiva da ocorrência da infração penal”. Cf. O relacionamento entre o Ministério Público e a polícia judiciária no processo penal acusatório in Revista Jurídica da Escola Superior do Ministério Público de São Paulo, ano I, $\mathrm{n}^{\circ}$ 2, ESMP, julho-dezembro de 2001, p. 104. 
vez que na instrução preliminar ministerial há efetiva relação de subordinação entre Parquet e polícia, ao menos no que diz respeito à investigação criminal.

Normalmente, elencam-se diversas vantagens apresentadas pelo sistema do promotor-investigador, entre as quais é possível mencionar a maior efetividade de suas investigações $^{358}$, característica esta que, reflexamente, confere maior celeridade e economia ao procedimento, além da maior consistência dos elementos probatórios colhidos $^{359}$ e da menor sujeição dos promotores a ingerências externas, o que, por seu turno, conduz ao menor risco de envolvimento destas autoridades em situações de corrupção.

Diversos inconvenientes também são apontados acerca da instrução preliminar realizada pelo Parquet, entre os quais a concentração de poderes na figura do promotor e na própria instituição do Ministério Público, que pode levar ao cometimento de atos com abuso de $\operatorname{poder}^{360}$, ao que soma o risco de a instituição colher elementos que favoreçam apenas a tese acusatória, comprometendo assim os resultados da investigação e prejudicando enormemente o investigado ${ }^{361}$.

Também se costuma lembrar como desvantagens da investigação ministerial sua falta de impessoalidade ${ }^{362}$, a violação à igualdade e à paridade de $\operatorname{armas}^{363}$, a possível seletividade ${ }^{364}$ das investigações, pois o Parquet poderia escolher quais delitos apurar ${ }^{365}$, a

358 Cf. RODRIGO CÉSAR REBELLO PINHO, Participação no Painel "O Ministério Público e a Investigação Criminal" do Seminário Propostas para um Novo Modelo de Persecução Criminal - Combate à Impunidade, Série Cadernos do CEJ, n 25, Brasília, CJF, 2005, p. 51.

359 Cf. NEREU JOSÉ GIACOMOLLI, A fase preliminar do processo penal - Crises, misérias e novas metodologias investigatórias, Rio de Janeiro, Lumen Juris, 2011, p. 30.

360 Cf. JOSÉ CARLOS FRAGOSO, São ilegais os "procedimentos investigatórios" realizados pelo Ministério Público Federal in Revista Brasileira de Ciências Criminais, nº. 37, São Paulo, Revista dos Tribunais, janeiro-março de 2002, p. 244.

361 Cf. NEREU JOSÉ GIACOMOLLI, A fase preliminar do processo penal - Crises, misérias e novas metodologias investigatórias, Rio de Janeiro, Lumen Juris, 2011, p. 30.

${ }^{362}$ Cf. ORLANDO MIRANDA FERREIRA, Inquérito policial e o Ato Normativo 314 - PGJ/CPJ in Revista Brasileira de Ciências Criminais, $n^{\circ}$. 45, São Paulo, Revista dos Tribunais, outubro-dezembro de 2003, p. 263.

${ }^{363}$ Cf. LUÍS GUILHERME VIEIRA, O Ministério Público e a investigação criminal in Revista Brasileira de Ciências Criminais, no. 46, São Paulo, Revista dos Tribunais, janeiro-fevereiro de 2004, pp. 314-315.

${ }^{364}$ Cf. GUILHERME DE SOUZA NUCCI, A investigação criminal e a atuação do Ministério Público in Revista CEJAP, vol. 5, no 7, 2004, p. 23.

${ }^{365}$ Cf. FÁBIO MOTTA LOPES, A impossibilidade de o Ministério Público investigar no âmbito criminal in Revista CEJ (Conselho de Estudos Judiciários), vol. 13, n 47, 2009, p. 99. 
ausência de controle sobre sua atividade investigatória ${ }^{366}$, e a falta de estrutura material e pessoal para que o Parquet assuma mais esta função ${ }^{367}$.

Entre os Estados que já adotaram o modelo do promotor-investigador, é possível mencionar Itália, Alemanha, Portugal, diversos países da América Latina, entre outros.

\subsubsection{Itália}

Neste país, o Código de Processo Penal de 1988 alterou o regime de instrução judicial até então vigente para substituí-lo pelo modelo de investigação ministerial, no qual ao Parquet é atribuída a função de conduzir a instrução, cabendo à polícia a realização das diligências determinadas, ou então de atividades que lhe são típicas, a exemplo da identificação criminal ${ }^{368}$.

Trata-se de uma investigação unitária, na qual Ministério Público e polícia judiciária atuam no âmbito de suas respectivas atribuições: a última age em função daquilo que o Parquet determina para o êxito da investigação (o que não retira, porém, o poder de iniciativa de seus membros), ao passo que o Ministério Público, como titular da ação penal e "dominus" da fase investigatória, utiliza esta para colher os elementos necessários à apresentação ao juiz das razões da acusação que pretende formular ${ }^{369}$.

Esta etapa pré-processual da persecução penal recebeu o nome de indagini preliminari, e nela atua ainda um juiz de garantias, diferente do magistrado que conduzirá o processo penal, e responsável por analisar e autorizar medidas restritivas de direitos, o que só demonstra a preocupação do ordenamento italiano em evitar que esses elementos de informação colhidos na fase investigatória sejam utilizados na fase processual da persecução penal, ou influam na formação do convencimento do magistrado ${ }^{370}$.

${ }^{366}$ Cf. MAURÍCIO ZANÓIDE DE MORAES, Esgrimando com o professor Sérgio Marcos de Moraes Pitombo: os inexistentes poderes investigatórios criminais do Ministério Público in Revista do Advogado, $\mathrm{n}^{\circ}$ 78, ano XXIV, setembro de 2004, p. 69.

${ }^{367}$ Cf. ROGÉRIO LAURIA TUCCI, Ministério Público e investigação criminal, São Paulo, Revista dos Tribunais, 2004, p. 78.

${ }^{368}$ Cf. FAUZI HASSAN CHOUKR, Garantias constitucionais na investigação criminal, $2^{\mathrm{a}}$ ed., Rio de Janeiro, Lumen Juris, 2001, p. 63.

${ }^{369}$ Cf. MARZIA FERRAIOLI E ANDREA ANTONIO DALIA, Manuale di diritto procesuale penale, $7^{\mathrm{a}}$ ed., Padova, CEDAM, 2010, p. 416, 418 e 430.

${ }^{370}$ Cf. AURY LOPES JR., Sistemas de investigação preliminar no processo penal, Rio de Janeiro, Lumen Juris, 2001, pp. 223-224. 
A Itália talvez seja o país em que o direito à investigação é assegurado mais plenamente às partes, pois não apenas ao órgão da acusação é conferida a prerrogativa de investigar, como visto acima, mas também à defesa e à vítima. $\mathrm{O}$ ordenamento jurídico italiano, aliás, contém amplo e detalhado regramento da investigação defensiva, que assistiu à grande evolução nos últimos tempos.

$\mathrm{Na}$ verdade, o direito à investigação só veio a encontrar efetivo amparo legal na Itália quando da reforma que culminou no Código de Processo Penal de 1988. O Código anterior, de 1930, conhecido como Código Rocco e de viés flagrantemente autoritário, instituiu um sistema inquisitório no qual a atividade probatória, além de carecer de suficiente regulamentação, era incumbida essencialmente ao juiz. Como observa PAOLO TONINI ao tratar da matéria, "o juiz era "o senhor do processo e das provas"; durante a instrução, a verdade era investigada em sigilo, com amplos poderes coercitivos. No momento da fase de debates, as partes não tinham poderes incisivos de controle, pois a verdade já havia sido acertada e estava contida nos autos dos atos instrutórios"371.

No sistema processual penal italiano do Código de 1930, a atividade investigativa era vedada à defesa, que podia manifestar-se sobre o assunto apenas na fase debates, através do controle sobre a regularidade dos atos realizados naquela fase e da crítica às provas colhidas na instrução ${ }^{372}$.

O Código de 1988 acolheu o sistema acusatório e, nesse sentido, não só disciplinou pormenorizadamente o direito à prova como atribuiu às partes o poder de investigá-las, de requerer sua admissão e de contribuir para sua formação, na qual deve ser observado o princípio do contraditório.

Em matéria de investigação criminal, o novo Código de Processo Penal da Itália permitiu concluir claramente que incumbe às partes a busca de fontes de prova, tanto ao Ministério Público, que tem o ônus de provar e de convencer o juiz da culpa do imputado, como a este último, que pode colher fontes de prova que infirmem as trazidas pela acusação ou que lhe retirem a credibilidade ${ }^{373}$.

O Código de Processo penal italiano de 1988 criou, portanto, um novo modelo de instrução preliminar, as chamadas "indagini preliminari”, segundo o qual as

${ }^{371}$ Cf. A prova no processo penal italiano, trad. Alexandra Martins e Daniela Mróz, São Paulo, Revista dos Tribunais, 2002, p. 17.

${ }^{372}$ Cf. PASQUALE VENTURA, Le indagine difensive, Milano, Giuffrè, 2005, p. 07.

${ }^{373}$ Cf. PAOLO TONINI, A prova no processo penal italiano, trad. Alexandra Martins e Daniela Mróz, São Paulo, Revista dos Tribunais, 2002, pp. 60-61. 
investigações criminais devem ser conduzidas pelo Ministério Público, que pode contar com o apoio da polícia na realização das diligências. Imbuído ainda desse novo espírito, o legislador reformista previu a possibilidade de a defesa participar mais ativamente dessa fase, seja através da participação do advogado do investigado nos atos de instrução preliminar do Parquet, seja através das investigações privadas para a busca de fontes de $\operatorname{prova}^{374}$.

Sobre o assunto, observou ENNIO AMODIO que o novo código de processo penal italiano trouxe a figura do juiz de investigações preliminares como garante das liberdades do investigado, atribuiu ao Ministério Público ampla liberdade investigatória, muitas vezes subtraída ao rigor das formas e, em contrapartida, permitiu também à defesa realizar atos de investigação. Nesse sentido, acrescentou que "graças à contribuição de uma cultura totalmente externa aos acadêmicos puros, mas ancorada na experiência dos advogados, deu o código um desafogo concreto à exigência de tornar o defensor protagonista de autônomas atividades investigatórias paralelas às do Ministério Público. Com o art. 38 das disposições de atuação do CPP foi assim rompida uma enraizada regra deontológica que proibia aos defensores ter contatos com as testemunhas, 375 .

Sobre a investigação defensiva, cumpre mencionar que, inicialmente, as informações colhidas na investigação particular eram dirigidas ao Ministério Público ${ }^{376}$, pois a jurisprudência, ao interpretar o aludido art. 38 das disposições de atuação do Código de Processo Penal italiano, posicionava-se pela teoria da canalização, segundo a qual os elementos resultantes da investigação privada deveriam ser direcionados ao Ministério Público para serem passíveis de utilização ${ }^{377}$.

Entendia-se que os elementos de informação obtidos pela defesa não podiam ser levados diretamente à cognição do juiz, mas sim deveriam se restringir ao seu uso interno, ou no máximo serem entregues ao Ministério Público, que, no exercício de

\footnotetext{
${ }^{374}$ Cf. PASQUALE VENTURA, Le indagine difensive, Milano, Giuffrè, 2005, p. 09.

375 Cf. Vitórias e derrotas da cultura dos juristas na elaboração do novo Código de Processo Penal in Revista Brasileira de Ciências Criminais, nº 25, São Paulo, Revista dos Tribunais, janeiro-março de 1999, p. 20. O art. 38 das disposições de atuação do CPP a que aludiu o autor faz referência expressa ao art. 190, parágrafo primeiro do mesmo diploma (que assegura o direito à prova), e estabelece que "l'attività prevista dal primo comma può essere svolta, su incarico del difensori, da investigatori privati”.

376 Cf. ANTONIO SCARANCE FERNANDES, Reação defensiva à imputação, São Paulo, Revista dos Tribunais, 2002, p. 118.

377 Cf. ANDRÉ AUGUSTO MENDES MACHADO, Investigação criminal defensiva, São Paulo, Revista dos Tribunais, 2010, p. 145.
} 
suas funções, poderia requerer, por exemplo, a instauração de um incidente probatório com base nos informas trazidos ${ }^{378}$.

Há que se ressaltar, no entanto, que o referido art. 38 das disposições de atuação do Código de Processo Penal italiano continha uma mera enunciação de princípio, que assegurava ao defensor do investigado e do ofendido a faculdade de desenvolver investigações para buscar elementos de informação favoráveis ao assistido; o dispositivo não regulava as modalidades de desenvolvimento e documentação das investigações, nem a utilização de seus resultados, e justamente por isso o tema gerava tanta controvérsia, e até mesmo impedia o exercício mais amplo do direito à investigação pela defesa. Lembra PASQUALE VENTURA que a interpretação restritiva do art. 38 das disposições de atuação do Código de Processo Penal italiano pela jurisprudência na verdade acentuou a disparidade de tratamento entre acusação e defesa, mortificando a faculdade de realizar investigações do defensor ${ }^{379}$.

No intuito de restabelecer o equilíbrio entre as partes na fase investigativa, em 1995 foi editada a Lei $n^{\circ} 332$, que permitia que os elementos colhidos na investigação defensiva fossem endereçados ao juiz e não mais ao Parquet $^{380}$.

Referido texto normativo, no entanto, não disciplinou as modalidades de desenvolvimento das investigações privadas, tampouco sua forma de documentação, além do que, na prática, o valor probatório conferido às investigações defensivas ainda era inferior ao das investigações do Parquet ${ }^{381}$.

A fim de assegurar uma igualdade mais efetiva entre as partes na fase investigatória, foram feitas alterações no ordenamento italiano em 1999, que redundaram

378 Cf. GIORGIO LATTANZI E ERNESTO LUPO, Codice di procedura penale - Rassegna di giurisprudenza e di dottrina - Atti e prove, Libri II e III, Milano, Giuffrè, 1997, p. 581.

${ }^{379}$ Cf. PASQUALE VENTURA, Le indagine difensive, Milano, Giuffrè, 2005, pp. 09-16. Complementa o jurista que a orientação jurisprudencial reinante à época acabava por desrespeitar o princípio da participação paritária da acusação e da defesa em todas as fases e graus do procedimento. Nas palavras do autor, "é verdade que não pode existir identidade de poderes entre acusação e defesa, sobretudo na fase das investigações preliminares em que o Ministério Público e a polícia judiciária podem realizar atos limitativos de liberdade protegidos pela Constituição; todavia parecia injustificado negar à defesa, fora os atos que envolviam o sacrifício da liberdade individual, aquilo que era permitido à acusação”. Em vernáculo: "è vero che non ci può essere identità di poteri fra accusa e difesa, soprattutto nella fase delle indagini preliminari in cui pubblico ministero e polizia giudiziaria possono compiere atti limitativi di libertà protette dalla Costituzione; tuttavia appariva ingiustificato negare alla difesa, al di fuori di atti che non comportino il sacrifício di libertà individuali, ciò che invece veniva concesso all'accusa".

${ }^{380}$ Cf. ANDRÉ AUGUSTO MENDES MACHADO, Investigação criminal defensiva, São Paulo, Revista dos Tribunais, 2010, p. 146.

${ }^{381}$ Cf. PASQUALE VENTURA, Le indagine difensive, Milano, Giuffrè, 2005, p. 19. 
em maior autonomia à investigação privada ${ }^{382}$. Mas foi apenas com a Lei $n^{0} 397$, de 07 de dezembro de 2000, que a instrução preliminar defensiva foi regulada detalhadamente na Itália, e ao advogado do imputado, da vítima e de outras partes privadas foram conferidas prerrogativas antes restritas ao Ministério Público e à polícia ${ }^{383}$.

A partir do ano $2000^{384}$, foi possibilitado ao defensor, no curso da investigação particular, realizar as seguintes medidas: entrevistar pessoal e informalmente potenciais testemunhas, colher declaração escrita de pessoas, com a cominação do crime de falso testemunho, requerer laudos periciais ou produzi-los através de assistentes técnicos, efetuar vistoria em coisas ou inspecionar lugares públicos e privados, solicitar documentos em poder da Administração Pública, formar o instrumento para documentação dessas atividades, entre outras ${ }^{385}$.

MARZIA FERRAIOLI e ANDREA ANTONIO DALIA chamam a atenção para o fato de que essas medidas foram previstas com o objetivo de permitir que o advogado participe ativamente das investigações e contribua eficazmente ao acertamento dos fatos, no interesse de seu assistido, o que assegura, no fim, o próprio direito à prova ${ }^{386}$.

Oportuno salientar que, na Itália, a iniciativa investigatória pertence ao defensor, não ao assistido, e não apenas do imputado, mas de qualquer das partes privadas. Desse modo, também a vítima e o responsável civil, por exemplo, podem ver realizadas investigações particulares através de seus advogados ${ }^{387}$.

382 Cf. ANTONIO SCARANCE FERNANDES, Reação defensiva à imputação, São Paulo, Revista dos Tribunais, 2002, p. 119.

${ }^{383}$ Cf. ÉDSON LUÍS BALDAN, Investigação defensiva: o direito de defender-se provando in Revista Brasileira de Ciências Criminais, $\mathrm{n}^{\circ}$ 64, São Paulo, Revista dos Tribunais, janeiro-fevereiro 2007, p. 271.

${ }^{384}$ A investigação defensiva deixou de ser mera previsão abstrata a partir da Lei ${ }^{\circ} 397 / 2000$, que veio a disciplinar o procedimento para a realização desse tipo de instrução preliminar, mas como bem salientou ANDRÉ AUGUSTO MENDES MACHADO, a regulamentação trazida pelo diploma não é exaustiva, "sendo completada pelas Regole di comportamento del penalista nelle investigazioni difensiva, cujo texto foi aprovado, em 14.07.2001, pela Unione Camere Penali Italiane (associação italiana de advogados criminalistas). Tais regras possuem valor convencional, isto é, vinculam somente os advogados inscritos nas Câmeras Penais. Além disso, em 26.10.2002, o Consiglio Nazionale Forense, órgão de representação institucional da advocacia, introduziu modificações ao Código Deontológico, com o objetivo de disciplinar o desenvolvimento da investigação defensiva. A violação dessas disposições é punida com sanções disciplinares". Cf. A investigação criminal defensiva, São Paulo, Revista dos Tribunais, 2010, p. 147. nota 64.

385 Os atos de investigação facultados à defesa foram objeto de breve e objetiva análise pelo jurista italiano ANIELLO NAPPI em sua obra Guida breve alla procedura penale, $2^{\mathrm{a}}$ ed., Milano, Giuffrè, 2004, pp. 200207.

${ }^{386}$ Cf. Manuale di diritto procesuale penale, $7^{\mathrm{a}}$ ed., Padova, CEDAM, 2010, p. 487.

${ }^{387}$ Cf. ANDRÉ AUGUSTO MENDES MACHADO, Investigação criminal defensiva, São Paulo, Revista dos Tribunais, 2010, pp. 148-149. Acrescenta ainda o autor que "essa atividade investigatória pode ser promovida por defensor particular ou dativo, em qualquer estado e grau de persecução criminal, na execução penal, para promover a revisão criminal e até mesmo de forma preventiva, caso exista a 
Observe-se ainda que o ordenamento italiano preocupou-se também em assegurar que mesmo os imputados pobres ou sem advogados particulares desfrutem de tais prerrogativas inerentes ao exercício de seu direito de defesa, através do instituto do patrocínio custeado pelo Estado e da instituição de um defensor "de ofício" (público/dativo) $^{388}$.

O Código de Processo Penal italiano vigente autoriza ainda que o defensor seja auxiliado por assistente técnico ou investigador privado autorizado, figura esta que consiste numa espécie de investigador particular especialmente qualificado, que, depois de adquirir certa maturidade profissional, obtém autorização para exercer investigação defensiva, expedida pelo Prefeito da província onde irá atuar ${ }^{389}$.

Vale lembrar que, no desenvolvimento das investigações, o defensor, seja do imputado ou de qualquer das partes privadas, pode também nomear um substituto para realizar as funções que lhe foram originalmente incumbidas. Tal nomeação pode ter caráter genérico, o que permite a prática de quaisquer atos investigativos pelo substituto, ou específico, quando for concedida a substituição para a prática de diligências certas e $\operatorname{determinadas}^{390}$.

E, no que diz respeito à utilização dos elementos de informação obtidos através das investigações privadas, o Código de Processo Penal italiano faculta à defesa apresentar à autoridade judiciária apenas os informes que reputar favoráveis. Ou seja, o defensor pode escolher se e quando usar as documentações resultantes das investigações.

$\mathrm{Na}$ verdade, o defensor não precisa nem registrar formalmente o resultado da investigação se o mesmo for desfavorável ao seu cliente, prerrogativa esta que não se

possibilidade de instauração de procedimento criminal. Em suma, o defensor pode investigar sempre que houver a necessidade de procurar elementos de prova favoráveis ao assistido, não obstante esta atividade se manifestar com maior freqüência na fase de persecução prévia".

388 Cf. PASQUALE VENTURA, Le indagine difensive, Milano, Giuffrè, 2005, pp. 20-23.Sobre tal figura, veja-se mais em GASPARE DALIA, Il nuovo ruolo del diffensore di ufficio e la disciplina del gratuito patrocínio in Il nuovo ruolo del difensore nel processo penale, coord. Andréa Antonio Dalia e Marzia Ferraioli, Giuffrè Editore, Milano, 2002, pp. 11-82.

${ }^{389}$ Cf. GIOVANNI CONSO e VITTORIO GREVI, Compendio di procedura penale, Padova, Cedam, 2001, pp. 485. Ainda sobre o tema, acrescentam os autores que os investigadores privados autorizados são equiparados aos assistentes técnicos na faculdade de abster-se de testemunhar, por segredo profissional, sobre o conteúdo e os resultados da investigação particular. Sobre a qualificação do investigador privado, a amplitude de seus poderes e sua relação com o defensor, veja-se mais em GIANLUCA D'AIUTO, L'estensione all'invesigatore privato delle garanzie di liberta del difensore in Il nuovo ruolo del difensore nel processo penale, coord. Andréa Antonio Dalia e Marzia Ferraioli, Giuffrè Editore, Milano, 2002, pp. 83100.

${ }^{390}$ Cf. PASQUALE VENTURA, Le indagine difensive, Milano, Giuffrè, 2005, pp. 34-35. 
estende ao Parquet ou à polícia, que estão obrigadas a documentar seus atos investigatórios $^{391}$.

Proibi-se, no entanto, a utilização de apenas parte de um ato investigatório (por exemplo, o defensor não pode apresentar à autoridade apenas a parte do depoimento de uma testemunha que é favorável ao seu assistido). Isto porque tal conduta implicaria, em última análise, a falsificação da documentação produzida. A propósito, vale a pena mencionar que o defensor pode cometer crimes como o de favorecimento pessoal ou de falsidade se agir em desacordo com os limites legais estabelecidos para o exercício dessa atividade $^{392}$.

A regulamentação da investigação defensiva no ordenamento italiano denota a preocupação do legislador local em definir bem o modo de realização dos atos investigatórios, sua instrumentalização e formalização, bem como os limites para a utilização das informações obtidas. Não obstante, a disciplina legal atinente à investigação defensiva tem sido alvo de severas críticas, por conta dos inconvenientes que apresenta.

Em relação às referidas desvantagens da investigação privada, a ausência de poderes coercitivos por parte dos defensores é lembrada como um fator de desequilíbrio entre o imputado e o Ministério Público, além do fato de que, corriqueiramente, mesmo após as alterações no ordenamento italiano, é atribuído maior peso aos elementos de informação colhidos pelo Parquet do que pela defesa ${ }^{393}$.

A falta de consenso sobre a qualificação subjetiva do causídico que documenta a investigação defensiva - se pública ou privada ${ }^{394}$ - também têm gerado

\footnotetext{
${ }^{391}$ Cf. ANDRÉ AUGUSTO MENDES MACHADO, Investigação criminal defensiva, São Paulo, Revista dos Tribunais, 2010, p. 154.

392 Cf. PASQUALE VENTURA, Le indagine difensive, Milano, Giuffrè, 2005, pp. 150 e 179-180. A propósito, sobre os crimes de possível cometimento no âmbito das investigações defensivas na Itália recomenda-se a leitura dos seguintes artigos: ELIO LO MONTE, Il delitto di rivelazione di segretti inerenti ad un procedimento penale in Il nuovo ruolo del difensore nel processo penale, coord. Andréa Antonio Dalia e Marzia Ferraioli, Giuffrè Editore, Milano, 2002, pp. 343-381, e CARLO LONGOBARDO, Le false dichiarazione al difensore in Il nuovo ruolo del difensore nel processo penale, coord. Andréa Antonio Dalia e Marzia Ferraioli, Giuffrè Editore, Milano, 2002, pp. 383-422.

${ }^{393}$ Nesse sentido, afirma GUSTAVO HENRIQUE IVAHY BADARÓ que "a defesa, no curso da indagine preliminare, encontra-se em posição de nítida inferioridade em relação à acusação, não só pela dificuldade, de ordem essencialmente prática para desenvolver uma autônoma atividade investigatória, voltada à descoberta de fontes de provas a favor do investigado, mas sobretudo pela relevância que tem no dibattimento muitos dos atos atribuídos ao Ministério Público”. Cf. Ônus da prova no processo penal, São Paulo, Revista dos Tribunais, 2003, p. 145.

${ }^{394}$ Para ANIELLO NAPPI, por exemplo, ao realizar investigações criminais o defensor não assume função pública, porque efetua atividade que é manifestação de uma livre escolha acerca da modalidade de exercício do direito de defesa. Cf. Guida breve allá procedura penale, $2^{\mathrm{a}}$ ed., Milano, Giuffrè, 2004, p. 200.
} 
discussões na Itália acerca das possíveis diferentes conseqüências para o advogado que procede ao registro infiel dos atos investigatórios ${ }^{395}$.

Fala-se também que, na prática, a investigação defensiva acentua a desigualdade entre os imputados ricos e pobres ${ }^{396}$, bem como gera dúvidas acerca da veracidade das informações obtidas, dada a premente parcialidade com que é desenvolvida $^{397}$.

A doutrina italiana discute também as repercussões da investigação defensiva sobre a proteção de dados pessoais e a possibilidade de realização de atos investigatórios atípicos pela defesa ${ }^{398}$.

Em que pesem as críticas e vulnerabilidades do sistema italiano de investigação defensiva, fato é que a previsão legal de tal tipo de instrução, bem como sua regulamentação, constituem uma inovação positiva, pois asseguram plenamente o direito à investigação à defesa e permitem, de algum modo, maior equilíbrio entre esta e a acusação, numa nobre tentativa de fornecer a ambas as mesmas armas na fase inicial da persecução penal $^{399}$. Recorde-se ainda que as chamadas "indagini difensive" foram facultadas também à vítima e a outras partes privadas no processo penal italiano, o que, sem dúvida, revela ser possível não só no plano teórico mas também no plano concreto a asseguração do direito à investigação ao ofendido.

\subsubsection{Alemanha}

Já na Alemanha, há muito tempo a investigação criminal fica a cargo do Ministério Público, considerado o dirigente e o destinatário de tal atividade ${ }^{400}$. Não

\footnotetext{
395 Veja-se mais sobre o assunto em ANDRÉ AUGUSTO MENDES MACHADO, Investigação criminal defensiva, São Paulo, Revista dos Tribunais, 2010, pp. 165-166.

${ }^{396}$ Cf. ANTONIO MAGAlHÃes GOMES FILHO, Direito à Prova no Processo Penal, São Paulo, Revista dos Tribunais, 1997, p. 87.

397 Cf. ANTONIO SCARANCE FERNANDES, Reação defensiva à imputação, São Paulo, Revista dos Tribunais, 2002, p. 119.

${ }^{398}$ Cf. ANDRÉ AUGUSTO MENDES MACHADO, Investigação criminal defensiva, São Paulo, Revista dos Tribunais, 2010, pp. 166-168.

399 ÉDSON LUÍS BALDAN arrola ainda outros benefícios da investigação defensiva, a exemplo do conseqüente aprimoramento das investigações públicas, a criação da categoria profissional dos investigadores privados, o estímulo das ciências afins ao direito penal, a maior importância conferida aos advogados, a obrigação da motivação judicial na admissão da acusação e a maior proximidade do processo penal com a dita "verdade real". Cf. Investigação defensiva: o direito de defender-se provando in Revista Brasileira de Ciências Criminais, $n^{0}$ 64, São Paulo, Revista dos Tribunais, janeiro-fevereiro 2007, pp. 270-271.

${ }^{400}$ Cf. FAUZI HASSAN CHOUKR, Garantias constitucionais na investigação criminal, $2^{\mathrm{a}}$ ed., Rio de Janeiro, Lumen Juris, 2001, p. 57.
} 
obstante, há também órgãos de polícia federal e estaduais ${ }^{401}$ que, na prática, acabam realizando a maior parte das diligências relativas à instrução preliminar ${ }^{402}$. Fala-se até numa relação legal de encargo nesse sentido, onde a polícia seria mandatária do Parquet ${ }^{403}$.

Na verdade, o sistema alemão se aproxima do italiano ${ }^{404}$, distinguindo-se deste fundamentalmente pelo fato de que o Parquet está inserido constitucionalmente no Poder Executivo (embora haja uma série de prerrogativas e peculiaridades tendentes a lhe conferir maior independência, e que acabam por aproximar seus integrantes daqueles do Poder Judiciário $)^{405}$. Na Itália, não custa recordar, os promotores integram o Poder Judiciário, possuindo as mesmas garantias que os magistrados, mas diferenciando-se destes pela função postulatória que exercem ${ }^{406}$.

Como se vê, na Alemanha, embora ao órgão da acusação seja amplamente assegurado o direito à investigação, o mesmo não se verifica em relação à defesa, que ainda prescinde do reconhecimento de prerrogativas dessa ordem para que seu próprio direito à prova reste plenamente assegurado.

\subsubsection{Portugal}

Em Portugal, a instrução preliminar, lá chamada simplesmente de inquérito, também é conduzida pelo Ministério Público, como decorrência de sua primordial função de promover a perseguição das infrações penais ${ }^{407}$. O exercício dessa atividade, porém, se

401 Cf. VINÍCIO STEIN CAMPOS, A força dos grupos de pressão sobre a proposta de mudanças na investigação criminal, na reforma do processo penal brasileiro in Revista A Força Policial, $\mathrm{n}^{\circ}$ 60, São Paulo, outubro-dezembro de 2008, p. 26.

402 Cf. AURY LOPES JR., Sistemas de investigação preliminar no processo penal, Rio de Janeiro, Lumen Juris, 2001, p. 230.

${ }^{403}$ Cf. KAI AMBOS, Control de la policía por el fiscal versus domínio policial de la instrucción in Revista Jurídica da Escola Superior do Ministério Público de São Paulo, ano I, nº 2, ESMP, julho-dezembro de 2001, p. 121.

${ }^{404}$ Cf. FAUZI HASSAN CHOUKR, Garantias constitucionais na investigação criminal, $2^{\mathrm{a}}$ ed., Rio de Janeiro, Lumen Juris, 2001, p. 57.

405 Cf. DENISE NEVES ABADE, Garantias do processo penal acusatório - O novo papel do Ministério Público no processo penal de partes, Rio de Janeiro, Renovar, 2005, pp. 35-36.

${ }^{406}$ Cf. DENISE NEVES ABADE, Garantias do processo penal acusatório - O novo papel do Ministério Público no processo penal de partes, Rio de Janeiro, Renovar, 2005, pp. 38-40.

${ }^{407}$ Cf. JORGE DE FIGUEIREDO DIAS, Direito processual penal, Coimbra, Coimbra Editora, 2004, p. 395. 
dá com a assistência da polícia criminal ${ }^{408}$, que atua sob seu mando direto e dependência funcional $^{409}$.

É válido ressaltar que no ordenamento português, o Parquet integra o Poder Judiciário, e seus membros, conhecidos como "magistrados do Ministério Público", possuem as mesmas prerrogativas conferidas aos juízes ${ }^{410}$.

A propósito, os magistrados também podem praticar alguns atos instrutórios (têm, por exemplo, livre disposição sobre os atos a serem investigados), mas nem por isso são considerados juízes instrutores, já que o protagonista da investigação criminal é realmente o Parquet ${ }^{411}$. E a exemplo do que ocorre na Itália, existe a figura do juiz garante, encarregado de ordenar ou autorizar a realização de atos investigatórios potencialmente ofensivos aos direitos e garantias fundamentais ${ }^{412}$.

Mencione-se ainda a existência de exceções à regra de atribuição ao Parquet da direção da instrução preparatória: infrações julgadas em processo sumário e contravenções podem ser investigadas por autoridades administrativas diversas, assim como ocorre com os crimes cometidos por juízes, em que a instrução prévia é dirigida por um magistrado ${ }^{413}$.

E se ao Ministério Público é reconhecido amplamente o direito à investigação no ordenamento português, o mesmo não se pode afirmar em relação à defesa: ao advogado do argüido não é reconhecido o direito de promover investigações autônomas relativas ao fato criminoso e suas circunstâncias; ser-lhe-ia facultado apenas apresentar memoriais ou requerer a realização de diligências ao Parquet, que as deferiria se entendesse que pudessem contribuir para a descoberta da verdade.

No entanto, há quem sustente que, mesmo diante da falta de previsão e regulamentação legal, a realização de investigações pela defesa seria possível. Este é, por

\footnotetext{
${ }^{408}$ Cf. EDUARDO LUIZ SANTOS CABETTE, O papel do inquérito policial no sistema acusatório - o modelo brasileiro in Revista Brasileira de Ciências Criminais, $n^{\circ}$ 35, São Paulo, Revista dos Tribunais, julhosetembro de 2001, p. 190.

${ }^{409}$ Cf. AURY LOPES JR., Sistemas de investigação preliminar no processo penal, Rio de Janeiro, Lumen Juris, 2001, p. 236.

${ }^{410}$ Cf. DENISE NEVES ABADE, Garantias do processo penal acusatório - O novo papel do Ministério Público no processo penal de partes, Rio de Janeiro, Renovar, 2005, p. 52.

${ }^{411}$ Cf. FAUZI HASSAN CHOUKR, Garantias constitucionais na investigação criminal, $2^{\mathrm{a}}$ ed., Rio de Janeiro, Lumen Juris, 2001, pp. 67-68.

412 Cf. AURY LOPES JR., Sistemas de investigação preliminar no processo penal, Rio de Janeiro, Lumen Juris, 2001, p. 237.

${ }^{413}$ Cf. JORGE DE FIGUEIREDO DIAS, Direito processual penal, Coimbra, Coimbra Editora, 2004, p. 396.
} 
exemplo, o posicionamento de FRANCISCO DA COSTA OLIVEIRA ${ }^{414}$, e de JORGE DE FIGUEIREDO DIAS, para quem não está o defensor do imputado absolutamente impedido de proceder às suas próprias averiguações complementares, podendo fazê-lo sempre que o exercício de seu mister assim exigir. O jurista traz como exemplo de atos investigatórios realizáveis pela defesa o exame do lugar da infração e a busca de testemunhas ${ }^{415}$.

Ressalva, porém, FRANCISCO DA COSTA OLIVEIRA que talvez o principal obstáculo da investigação defensiva é o da escassez de meios de averiguação e obtenção de prova que envolvam terceiros ou poderes de autoridade, uma vez que nem o defensor nem o imputado gozam de poderes coercitivos, muitas vezes necessários quando há renitência em colaborar com o arguido ${ }^{416}$.

\subsubsection{América Latina}

$\mathrm{Na}$ América Latina, muitos países passaram por reformas processuais penais nas últimas décadas e adotaram o modelo de investigação ministerial, inspirados fundamentalmente nas diretrizes traçadas pelo Código de Processo Penal Modelo para a Ibero-América.

Também chamado de Código Processual Penal-Tipo para Ibero-América, o diploma prevê a adoção de um sistema acusatório, no qual o Ministério Público está incumbido não apenas da persecução penal dos crimes de ação pública, mas também da realização da instrução preliminar e da direção da polícia ${ }^{417}$.

Sobre o assunto, observa FAUZI HASSAN CHOUKR que o CódigoModelo atribui a condução das investigações ao Parquet, "que valoriza o acervo informativo com supremacia no que tange à etapa pré-processual, bem como no momento do arquivamento ou propositura da ação penal ${ }^{\text {,418. }}$.

\footnotetext{
${ }^{414}$ Cf. A defesa e a investigação do crime, $2^{\mathrm{a}}$ ed. Coimbra, Almedina, 2008, p. 31.

${ }^{415}$ Cf. Direito processual penal, Coimbra, Coimbra Editora, 2004, p. 488.

${ }^{416} \mathrm{Cf}$. A defesa e a investigação do crime, $2^{\mathrm{a}}$ ed. Coimbra, Almedina, 2008, pp. 55-56.

${ }^{417}$ Eis a previsão do art. 68 do diploma: 68. Função. Ao Ministério Púbico está confiado o exercício da persecução penal dos crimes de ação pública, dependam ou não dependam de representação ou de uma autorização estatal (art. 229), salvo nos casos expressamente excetuados pela lei. Com este propósito realizará todos os atos necessários para cumprir este fim, conforme as disposições deste Código e a lei que o organiza. Terá a seu cargo, especificamente, o procedimento preparatório (art. 250 e ss.) e a direção da polícia (art. 261) em sua função judicial.

${ }^{418}$ Cf. Garantias constitucionais na investigação criminal, 2a ed., Rio de Janeiro, Lumen Juris, 2001, p. 73.
} 
Quanto ao órgão policial, prevê o Código-Tipo que o mesmo deve auxiliar o Ministério Público na efetivação do procedimento preparatório, numa relação de expressa subordinação para com os membros daquela instituição ${ }^{419}$, o que não significa menosprezo à importância da polícia na fase inicial da persecução penal, principalmente considerando que são seus membros que normalmente têm o primeiro contato com a prática delitiva e que acabam por executar a maioria das ações concretas relativas à investigação ${ }^{420}$.

Fala-se até que o Ministério Público, sem a polícia, é como uma cabeça sem mãos, não pode atuar sem ela ${ }^{421}$. Todavia, nos países da América Latina que reformaram seus códigos de processo penal, atribuindo ao Parquet a condução da instrução preliminar, buscou-se conferir maior efetividade às investigações criminais, suprimindo as desvantagens do modelo de investigação policial e, principalmente, os traços autoritários contidos nas legislações até então vigentes, contempladoras ainda de um modelo inquisitório de processo penal.

Imperioso salientar, no entanto, que o Código Processual Penal-Tipo Para Ibero-América não previu para a defesa as mesmas prerrogativas conferidas à acusação no que diz respeito ao direito à investigação. Ao Ministério Público foram concedidos amplos poderes investigatórios ${ }^{422}$, ao passo que ao imputado e à vítima foi dado apenas o direito de

419 Nesse sentido são as seguintes previsões do Código-Modelo: “73. Função. A polícia, por iniciativa própria, em virtude de uma denúncia ou por ordem do Ministério Público, deverá investigar os fatos puniveis perseguíveis de ofício, impedir que os tentados ou os cometidos sejam levados a conseqüências posteriores, individualizar aos culpados e reunir os elementos de prova úteis para dar base à acusação ou determinar a absolvição antecipada. Se o fato punível depender, para sua persecução, de uma representação particular ou de uma autorização estatal, regerão as regras do art. 229. Os funcionários policiais serão auxiliares do Ministério Público para efetivar o procedimento preparatório”.

"74. Subordinação. Os funcionários da polícia administrativa, enquanto cumpram atos de polícia judicial, executarão suas tarefas sob a superintendência direta do órgão do Ministério Público e deverão executar suas ordens, sem prejuizo da autoridade administrativa à qual estejam submetidas. Deverão também cumprir as ordens que, para a tramitação do procedimento, lhe dirijam os Juizes perante quem tenha andamento o processo. O Ministério Público supervisionará o correto cumprimento da função judicial da polícia; poderá expedir a ela instruções gerais, cuidando de respeitar sua organização administrativa".

${ }^{420}$ Cf. FAUZI HASSAN CHOUKR, O relacionamento entre o Ministério Público e a polícia judiciária no processo penal acusatório in Revista Jurídica da Escola Superior do Ministério Público de São Paulo, ano I, $\mathrm{n}^{\circ} 2$, ESMP, julho-dezembro de 2001, pp. 104-105.

${ }^{421}$ Cf. JUAN-LUIS GÓMEZ COLOMER, La investigacion criminal: problemas actuales y perspectivas de unificacion internacional in Revista Jurídica da Escola Superior do Ministério Público de São Paulo, ano I, $\mathrm{n}^{\circ}$ 2, ESMP, julho-dezembro de 2001, p. 201.

${ }^{422} \mathrm{O}$ art. 250 do diploma em análise ilustra bem a abrangência do direito à investigação assegurado ao Parquet: "250. Objeto da investigação. Na busca da verdade (art. 232), o Ministério Público deverá praticar todas as diligências pertinentes e úteis para determinar a existência do fato, com todas as circunstâncias de importância para a lei penal, e seus participantes, procurando sua identificação e o conhecimento das circunstâncias pessoais que sirvam para valorar sua responsabilidade ou influam em sua punibilidade, verificando também o dano causado pelo delito, ainda quando não tenha exercido a ação civil". 
propor meios de prova durante o procedimento preparatório, cuja realização depende de um juízo de pertinência e utilidade do Parquet ${ }^{423}$.

No entanto, para a produção antecipada de provas o diploma exige que o pedido do Ministério Público seja deferido pelo juiz da instrução, que então determina a intimação de todos os intervenientes, seus defensores ou mandatários para a prática do ato. Apenas se este for de extrema urgência ou se ignore por completo quem seja o imputado, a diligência poderá ser realizada sem a intimação de quem quer que seja, mas há a designação de um defensor de ofício para controle do ato ${ }^{424}$.

${ }^{423}$ Eis o que dispõe sobre o assunto o art. 256 do Código-Tipo: "256. Proposição de diligências. O imputado, as pessoas a quem seja dado intervir no procedimento, seus defensores ou mandatários poderão propor meios de prova em qualquer momento do procedimento preparatório. O Ministério Público os levará a cabo se os considerar pertinentes e úteis, devendo fazer constar sua opinião em contrário aos efeitos que ulteriormente correspondam".

${ }^{424}$ Tais conclusões resultam da interpretação conjugada dos artigos 258 e 259 do Código-Modelo. 


\section{CAPÍTULO IV - DIREITO À INVESTIGAÇÃO E SEU EXERCÍCIO EM FACE DO SISTEMA PROCESSUAL PENAL BRASILEIRO EM VIGOR}

\subsection{CONSIDERAÇÕES INICIAIS}

Como já visto, o direito à investigação, entendido como um das prerrogativas do direito à prova, encontra amparo legal nos dispositivos que asseguram este último. Desse modo, não custa recordar que, embora a Constituição Federal de 1988 não assegure expressamente em seu rol de direitos e garantias fundamentais o direito à prova, entende-se que o mesmo foi garantido implicitamente, como consectário lógico de outros direitos, entre os quais o direito ao devido processo legal previsto no art. $5^{\circ}$, LIV, o direito ao contraditório e à ampla defesa, com os meios e recursos a ela inerentes, referido no art. $5^{\circ}, \mathrm{LV}$, e o próprio direito à presunção de inocência, tratado no art. $5^{\circ}$, LVII do texto constitucional $^{425}$.

Vale ainda lembrar que a incorporação ao ordenamento jurídico brasileiro do Pacto Internacional de Direitos Civis e Políticos de 1966, e da Convenção Americana de Direitos Humanos (ou Pacto de São José da Costa Rica) de 1969, corroborou a existência do direito à prova e, por conseguinte, do direito à investigação, em nosso País, a despeito da tese defendida por alguns juristas de que os tratados asseguraram, na verdade, o direito ao confronto ${ }^{426}$.

É que o primeiro diploma referido garante em seu artigo 14.3.e) o direito aos acusados de "interrogar ou fazer interrogar as testemunhas da acusação e de obter o comparecimento e o interrogatório das testemunhas de defesa nas mesmas condições de que dispõe as de acusação”, enquanto o último tratado, de forma semelhante ao anterior, assegura à defesa em seu artigo 8.2.f) o direito de "inquirir as testemunhas presentes no tribunal e de obter o comparecimento, como testemunhas ou peritos, de outras pessoas que possam lançar luz sobre os fatos”.

Aqui, buscou-se empreender uma análise não literal dos dispositivos mencionados, mas sim teleológica, abrangente, e consentânea com os demais direitos e

\footnotetext{
${ }^{425}$ Sobre o tema, v. considerações tecidas no item 1.3.1.1.

${ }^{426}$ DIOGO MALAN é um dos juristas que defende tal posicionamento, conforme visto no item 1.3.1.1.
} 
garantias assegurados por estes tratados, de modo que é possível afirmar que, mais do que o direito ao confronto, os diplomas reconheceram um verdadeiro direito à prova, extensível a todas as partes do processo, e em relação a todos os meios de prova e de investigação, aí incluídas não apenas as fontes pessoais mas também as reais.

Imperioso ainda mencionar que, não obstante a existência de inúmeros posicionamentos em contrário, o Supremo Tribunal Federal reconheceu o status normativo supralegal dos tratados internacionais de direitos humanos acima referidos, eis que aprovados sem o quorum qualificado previsto no art. $5^{\circ}, \S 3^{\circ}$ da Constituição. Dessa maneira, o Pacto Internacional de Direitos Civis e Políticos de 1966, e a Convenção Americana de Direitos Humanos de 1969 estariam abaixo da Constituição na pirâmide normativa, mas acima da legislação interna ${ }^{427}$.

Em suma, o direito à investigação encontra respaldo tanto na Constituição Federal de 1988 como nos tratados internacionais de direitos humanos incorporados ao nosso ordenamento, como decorrência do próprio direito à prova.

Resta agora verificar quais dispositivos da Carta Magna e das normas infraconstitucionais cuidam diretamente do direito à investigação, e em que medida o asseguram às possíveis partes de um processo penal, titulares do direito em análise, como visto alhures ${ }^{428}$.

Pois bem, o nosso ordenamento jurídico, notoriamente, adotou o modelo de investigação policial, pelo qual a promoção da instrução preliminar é tida como função precípua da polícia judiciária.

Decorre da leitura da própria Constituição Federal de 1988 a conclusão acima exposta, uma vez que os incisos I e IV do $\S 1^{\circ}$ do art. $144^{429}$ do diploma prevêem ser incumbência da polícia federal a apuração de infrações e o exercício, com exclusividade, das funções de polícia judiciária da União, e o $\S 4^{\circ}$ do mesmo dispositivo atribui às polícias

\footnotetext{
${ }^{427}$ Veja-se mais sobre o tema no item 1.3.1.2.

${ }^{428}$ Sobre o assunto, veja-se o item 2.3 .

${ }^{429}$ Eis o que estatuem os referidos dispositivos: “Art. 144. (...) $\S 1^{\circ}$ A polícia federal, instituída por lei como órgão permanente, organizado e mantido pela União e estruturado em carreira, destina-se a: I - apurar infrações penais contra a ordem politica e social ou em detrimento de bens, serviços e interesses da União ou de suas entidades autárquicas e empresas públicas, assim como outras infrações cuja prática tenha repercussão interestadual ou internacional e exija repressão uniforme, segundo se dispuser em lei; (...) IVexercer, com exclusividade, as funções de polícia judiciária da União”.
} 
civis as funções de polícia judiciária nos Estados e a apuração de infrações penais, exceto as militares ${ }^{430}$.

No entanto, a própria Constituição Federal alude à possibilidade de órgãos diversos da polícia judiciária promoverem investigações criminais: no já referido art. 144, $\S 4^{\circ}$ do texto constitucional prevê-se que as infrações penais militares não são investigadas pela polícia civil, enquanto o art. 58, $\S 3^{\circ}$ do diploma dispõe sobre os poderes investigatórios das comissões parlamentares de inquérito, os quais abrangem o cometimento de ilícitos penais ${ }^{431}$.

O Código de Processo Penal vigente, na mesma esteira do texto constitucional, também prevê ser o inquérito policial a forma por excelência de investigação criminal em nosso ordenamento jurídico, ressalvando, porém, a existência de outras modalidades de instrução preliminar admissíveis. É o caput do art. $4^{\circ}$ do diploma ${ }^{432}$ que estabelece ser finalidade da polícia judiciária a apuração das infrações penais e de sua autoria, sendo que o parágrafo único ressalva que tal competência não exclui a de outras autoridades administrativas às quais seja atribuída idêntica função ${ }^{433}$.

$\mathrm{Na}$ verdade, inúmeras outras espécies de investigação penal têm sua realização pacificamente admitida em nosso País. Além dos já referidos inquérito policial militar $^{434}$ e do inquérito parlamentar ${ }^{435}$, é possível mencionar a investigação judicial de crimes eleitorais ${ }^{436}$, o inquérito promovido por autoridades florestais ${ }^{437}$, a investigação

\footnotetext{
430 Veja-se o exato teor do dispositivo mencionado: “Art. 144. (...) $\& 4^{\circ}$ Às polícias civis, dirigidas por delegados de polícia de carreira, incumbem, ressalvada a competência da União, as funções de polícia judiciária e a apuração de infrações penais, exceto as militares".

${ }^{431} \mathrm{O}$ referido dispositivo estabelece o seguinte: "Art. 58. (...) $\S 3^{\circ}$ As comissões parlamentares de inquérito, que terão poderes de investigação próprios das autoridades judiciais, além de outros previstos nos regimentos das respectivas Casas, serão criadas pela Câmara dos Deputados e pelo Senado Federal, em conjunto ou separadamente, mediante requerimento de um terço de seus membros, para a apuração de fato determinado e por prazo certo, sendo suas conclusões, se for o caso, encaminhadas ao Ministério Público, para que promova a responsabilidade civil ou criminal dos infratores".

${ }^{432}$ Eis o teor integral do mencionado dispositivo de lei: "Art. $4^{\circ}$. A polícia judiciária será exercida pelas autoridades policiais no território de suas respectivas circunscrições e terá por fim a apuração das infrações penais e da sua autoria. Parágrafo único. A competência definida neste artigo não excluirá a de autoridades administrativas, a quem por lei seja cometida a mesma função".

433 Mencione-se ainda que os artigos 27 e $39, \S 5^{\circ}$, do Código de Processo Penal corroboram a admissibilidade de outras formas de investigação criminal em nosso ordenamento jurídico, pois tratam da possibilidade de o órgão responsável pela acusação promover ação penal baseado meramente em peças de informação levadas a ele que contenham os elementos de convicção necessários ao oferecimento de uma denúncia.

${ }^{434}$ Código de Processo Penal Militar (Decreto-Lei $\left.n^{\circ} 1.002 / 69\right)$, art. $8^{\circ}$, a), e $9^{\circ}$.

${ }^{435}$ Constituição Federal de 1988 , art. $58, \S 3^{\circ}$, e Lei ${ }^{\circ} 1.579 / 59$, art. $2^{\circ}$.

${ }^{436}$ Lei Complementar $n^{\circ}$ 64/90, art. 22.

${ }^{437}$ Código Florestal (Lei no $4.771 / 65$ ), art. 33, caput e letra b).
} 
realizada por autoridades sanitárias e alfandegárias ${ }^{438}$, a investigação judicial dos crimes cometidos por magistrados ${ }^{439}$, a investigação ministerial dos crimes cometidos por membros do Parquet ${ }^{440}$, as investigações do Supremo Tribunal Federal ${ }^{441}$ e as investigações administrativas ${ }^{442}$.

$\mathrm{O}$ inquérito judicial realizado no curso das falências costumava ser lembrado como outra espécie de instrução preliminar admitida em nosso ordenamento, mas com o advento da Lei $n^{\circ}$ 11.101/05, conhecida como Lei de Recuperação de Empresas e de Falências, deixou de existir ${ }^{443}$. Da mesma forma, a investigação judicial dos crimes praticados por organizações criminosas era usualmente citada como exemplo de instrução preliminar realizada por órgão diverso da polícia. No entanto, tal espécie de investigação criminal prevista na Lei $\mathrm{n}^{\mathrm{o}} 9.034 / 95$, art. $2^{\circ}$, III, e $3^{\circ}$, deixou de ser admitida após o Supremo Tribunal Federal, em 2004, ter julgado parcialmente procedente a ADIN 1570/DF, para declarar a inconstitucionalidade do artigo $3^{\circ}$, no que se refere aos dados "fiscais" e "eleitorais". No que diz respeito às informações "bancárias" e "financeiras" também referidas no dispositivo legal, só não houve a declaração de inconstitucionalidade pois a matéria já fora revogada pela Lei Complementar $n^{\circ} 105 / 01$, que disciplinou o acesso a tais informes de maneira diversa da Lei $n^{\circ} 9.034 / 95^{444}$.

Pois bem, se as modalidades acima referidas de instrução preliminar são admitidas sem maiores controvérsias em nosso ordenamento jurídico, o mesmo não se pode dizer em relação às investigações promovidas pelas possíveis partes em um processo penal, titulares do direito à investigação.

A realização de atos investigatórios na esfera penal pelo Ministério Público, por exemplo, foi alvo de intensas críticas e teve sua constitucionalidade posta em xeque diversas vezes. Quanto ao suspeito, ainda se discute a própria existência do direito de defesa na etapa inicial da persecução penal, o que revela a dificuldade de admitir a realização de investigações defensivas. Já a vítima não tem sequer sua atuação como assistente de acusação admitida nesta fase, o que praticamente impossibilita cogitar da

${ }^{438}$ Lei $6.437 / 77$, art. $2^{\text {o e art. } 12 .}$

${ }^{439}$ Lei Orgânica da Magistratura Nacional (Lei Complementar $n^{\circ}$ 35/79), art. 33.

${ }^{440}$ Lei Orgânica Nacional do Ministério Público (Lei no 8.625/93), art. 41.

${ }^{441}$ Regimento Interno do Supremo Tribunal Federal, art. 43.

${ }^{442}$ Lei 8.112/90, art. 154.

${ }^{443}$ De acordo com a sistemática instaurada pela Lei $n^{\circ} 11.101 / 05$, a investigação dos crimes falimentares não é mais feita por meio do inquérito judicial, e sim do inquérito policial, isto quando já não houver os elementos necessários ao oferecimento da denúncia, hipótese em que o inquérito policial será dispensável.

${ }_{444}$ Veja-se mais sobre o assunto em GUILHERME MADEIRA DEZEM, Lei do crime organizado in Legislação penal especial, vol. 2, 2ª ed., São Paulo, Premier Máxima, 2008, pp. 343-344. 
realização de determinados atos investigatórios, em se tratando de ação penal de iniciativa pública.

O cenário acima descrito causa certa estranheza, senão estupefação, se consideradas as premissas teóricas até o momento expostas, segundo as quais a realização de investigações criminais constitui na verdade um direito público subjetivo das possíveis partes de um processo penal, decorrente do próprio direito à prova.

De início nota-se, portanto, a enorme distância existente entre o reconhecimento do direito à investigação no plano teórico e o modo como tem sido tratado na realidade brasileira, o que se deve, em grande parte, à disciplina conferida ao tema pelas normas vigentes.

Torna-se, assim, imperiosa a análise do sistema jurídico em vigor a fim de que sejam conhecidas as razões pelas quais a concretização do direito à investigação encontra tamanha resistência em nosso País. Somente assim será possível rebater os argumentos comumente suscitados em desfavor de tal direito a fim de que ele possa gozar, cada vez mais, de plena efetividade, o que não impede, porém, a formulação de propostas de alterações legislativas - e a análise das já existentes - com vistas a tornar expresso tal direito, e permitir seu exercício de modo mais pacífico e seguro.

\subsection{INVESTIGAÇÃO CRIMINAL E MINISTÉRIO PÚBLICO}

No que diz respeito ao exercício do direito à investigação pelo Ministério Público, é possível afirmar que apenas nas últimas décadas assistiu-se a um movimento pelo qual os membros do Parquet passaram a realizar eles próprios diligências investigatórias. $\mathrm{O}$ aumento do número de crimes cometidos em nosso País, o recrudescimento da violência, a ascensão das organizações criminosas, mais complexas, são algumas das razões que explicam tal tendência, ao lado da propalada ineficiência das instituições policiais, que não conseguiram combater o avanço da criminalidade e têm seus membros muitas vezes envolvidos na prática de delitos.

Tão logo foi identificada esta atividade do Parquet, passou-se a discutir, mais que a legalidade, a constitucionalidade das investigações realizadas pela instituição. Sem dúvida alguma, em matéria de investigação criminal, a Constituição Federal de 1988 atribuiu ao Ministério Público, em seu art. 129, VII e VIII, as funções de exercer o controle 
externo da atividade policial, e de requisitar diligências investigatórias e a instauração de inquérito policial. Também cabe ao Parquet promover, privativamente, a ação penal pública, nos termos do inciso I do referido artigo. Todavia, nenhum dispositivo da Carta em vigor atribuiu expressamente ao Ministério Público o poder de realizar investigações penais, diferentemente do que ocorreu em relação à polícia e às comissões parlamentares de inquérito.

Inúmeros argumentos foram então suscitados pelos juristas contrários à realização da instrução preliminar prévia pelo Parquet, um deles o uso da expressão "com exclusividade" no art. 144, $\S 1^{\circ}$, IV da Constituição Federal, para aludir ao exercício das funções de polícia judiciária da União pela polícia federal.

Para muitos autores ${ }^{445}$, o dispositivo referido impede as investigações criminais do Ministério Público, porque tal função seria privativa da polícia judiciária.

O jurista JOSÉ AFONSO DA SILVA, ao tratar do tema, afirmou que “argumenta-se que a Constituição não deferiu à Polícia Judiciária o monopólio da investigação criminal. É verdade, mas as exceções estão na própria Constituição e nenhuma delas contempla o Ministério Público. O próprio $\S 4^{\circ}$ do art. 144 ressalva a competência da União em contemplação da Polícia Judiciária Federal (art. 144, $\S 1^{\circ}$ ) e exclui da competência da Polícia Judiciária a apuração das infrações penais militares, em harmonia com o art. 124, com base no qual cabe à Polícia Judiciária Militar, exercida por autoridades das corporações militares no âmbito de cada qual, por meio de inquérito policial militar. Outra exceção que costuma se lembrar é a do poder investigatório das comissões parlamentares de inquérito, que também é expressa na Constituição (art. $58, \S$ $\left.3^{\circ}\right)^{, 446}$

\footnotetext{
${ }^{445}$ Por exemplo, MIGUEL REALE JÚNIOR, O crime de desobediência e os processos investigatórios do Ministério Público in Boletim do Instituto Manoel Pedro Pimentel, $\mathrm{n}^{\circ} 18$, ano , outubro-novembrodezembro de 2001, p. 09, LUIZ ALBERTO MACHADO, Palestra "Conversa com a Polícia Judiciária" realizada no IV Congresso Nacional de Delegados de Polícia de Carreira em Foz do Iguaçu, a 09/10/1996 in Revista ADPESP (Associação dos Delegados de Polícia do Estado de São Paulo), ano 17, $\mathrm{n}^{\circ}$ 22, São Paulo, dezembro de 1996, p. 63, JOSÉ CARLOS FRAGOSO, São ilegais os "procedimentos investigatórios" realizados pelo Ministério Público Federal in Revista Brasileira de Ciências Criminais, nº. 37, São Paulo, Revista dos Tribunais, janeiro-março de 2002, p. 242, ORLANDO MIRANDA FERREIRA, Inquérito policial e o Ato Normativo $314-P G J / C P J$ in Revista Brasileira de Ciências Criminais, ${ }^{\circ}$. 45, São Paulo, Revista dos Tribunais, outubro-dezembro de 2003, pp. 258-259, e LUÍS GULHERME VIEIRA, O Ministério Público e a investigação criminal in Revista Brasileira de Ciências Criminais, ${ }^{\circ}$. 46, São Paulo, Revista dos Tribunais, janeiro-fevereiro de 2004, p. 343.

${ }^{446}$ Cf. Em face da Constituição Federal de 1988, o Ministério Público pode realizar elou presidir investigação criminal, diretamente? in Revista Brasileira de Ciências Criminais, $\mathrm{n}^{\circ}$. 49, São Paulo, Revista dos Tribunais, julho-agosto de 2004, p. 380. Em outra oportunidade, ao interpretar o art. 144, § $4^{\circ}$, da Carta Magna, JOSÉ AFONSO DA SILVA afirmou que "a Constituição reservou à Polícia Civil Estadual um
} 
Mas há também vários juristas que interpretam o art. 144, $\S 1^{\circ}$, IV do texto constitucional de forma diversa, entendendo que a exclusividade ali mencionada diz respeito à organização das polícias, de modo que apenas a polícia federal pode exercer as funções de polícia judiciária da União; as polícias rodoviárias e ferroviárias federais e as polícias civis estaduais não poderiam, pois, exercer esta mesma atividade.

Segundo ADA PELLEGRINI GRINOVER, a exclusividade referida no art. 144 da Constituição diz respeito à "repartição de atribuições entre Polícia da União e Polícia Estadual, indicando a indelegabilidade das funções da primeira às Polícias dos Estados ${ }^{, 447}$.

De fato, o entendimento que se demonstra mais correto a respeito da previsão do $\S 1^{\circ}$, IV, do art. 144, da Constituição Federal é o de que a atribuição da exclusividade das funções de polícia judiciária da União à Polícia Federal não impediu outros órgãos/autoridades estatais de realizar investigações criminais, tanto porque esta é a interpretação do texto constitucional consentânea com o reconhecimento do direito à investigação, como porque a própria Carta Magna prevê expressamente a possibilidade de instituições diversas da polícia realizarem investigações criminais, a exemplo das comissões parlamentares de inquérito.

campo de atividade exclusiva que não pode ser invadido por norma infraconstitucional e, menos ainda, por disposições de ato administrativo. Uma delas é a realização do inquérito policial, que constitui o cerne da atividade da Polícia Judiciária”. Cf. Controle externo da atividade policial como uma das funções institucionais do Ministério Público - Entendimento do art. 129, VII, da Constituição Federal - Conteúdo da lei complementar e seus limites constitucionais - Competências exclusivas das polícias in Revista ADPESP, ano 17, $\mathrm{n}^{\circ}$ 22, São Paulo, dezembro de 1996, p. 23.

${ }^{447}$ Cf. Investigações pelo Ministério Público in Boletim do Instituto Brasileiro de Ciências Criminais, ano 12, $\mathrm{n}^{\circ}$ 145, dezembro de 2004, p. 04. No mesmo sentido são as opiniões de AURY LOPES JR., Sistemas de investigação preliminar no processo penal, Rio de Janeiro, Lumen Juris, 2001, p. 143, JOSÉ BARCELOS DE SOUZA, Investigação direta pelo Ministério Público in Revista Brasileira de Ciências Criminais, $\mathrm{n}^{\circ}$. 44, São Paulo, Revista dos Tribunais, julho-setembro de 2003, p. 364, LUIZ CARLOS DOS SANTOS GONÇALVES, A atuação criminal do Ministério Público: entre a tradição e a efetividade in Revista Brasileira de Ciências Criminais, nº. 46, São Paulo, Revista dos Tribunais, janeiro-fevereiro de 2004, p. 166, e MARCELLUS POLLASTRI LIMA. Explica este jurista que, a seu ver, "a Constituição Federal não dá às polícias civis dos Estados membros a exclusividade de apuração das infrações penais, e nem mesmo das atividades de polícia judiciária, pois o que faz é dizer que incumbe à polícia civil as funções de polícia judiciária e a apuração de infrações penais, mas sem o caráter de privatividade. (...) Mesmo em relação à Polícia Federal, o que é exclusivo é o exercício da polícia judiciária, e não a apuração de crimes (art. 144, $\S$ $\left.1^{\circ}, I V\right)$, já que a própria Constituição elenca exceções à regra geral, considerando ainda que as funções de polícia judiciária não se refletem necessariamente na apuração de crimes, cabendo também auxiliar a justiça criminal, fornecer informações necessárias à instrução e julgamentos de processos, realizar diligências requisitadas pelo juiz ou pelo Ministério Público e cumprir mandados de prisão, na forma do art. 13 do CPP”. Cf. O Ministério Público pode ou não investigar? Uma análise de recente decisão do STF, in Revista Brasileira de Ciências Criminais, nº 46, São Paulo, Revista dos Tribunais, janeiro-fevereiro de 2004, pp. 374-375. 
Aliás, as investigações penais promovidas por autoridades alfandegárias, sanitárias, florestais, entre outras, são amplamente reconhecidas como válidas em nosso ordenamento jurídico, como visto alhures, não tendo sequer sua constitucionalidade questionada. A constatação apenas reforça o acerto do entendimento acima exposto, aplicável também ao $\S 4^{\circ}$ do art. 144 da Constituição, o que permite afirmar que tampouco às polícias civis foi incumbida a apuração de infrações penais com exclusividade, embora a investigação criminal seja sua atribuição primordial.

Também o já referido art. 129 da Constituição Federal, que trata das funções institucionais do Ministério Público, costuma ser invocado por aqueles que sustentam a impossibilidade de o Parquet promover investigações criminais em nosso ordenamento jurídico. É que, entre as atribuições incumbidas expressamente ao Parquet na seara criminal, estão apenas a promoção da ação penal pública, o controle externo da atividade policial, a requisição de diligências investigatórias e a instauração de inquérito policial.

Muitos juristas sustentaram que o texto constitucional conferiu poderes investigatórios criminais ao Ministério Público com base na função que lhe foi atribuída pelo art. 129, VI, qual seja a de expedir notificações nos procedimentos administrativos de sua competência, requisitando informações e documentos para instruí-los. Para HUGO NIGRO MAZZILLI, por exemplo, "no inc. VI do art. 129, cuida-se de quaisquer procedimentos administrativos de atribuição do Ministério Público - e aqui também se incluem as investigações destinadas à coleta direta de elementos de convicção para a opinio delictis; se os procedimentos administrativos a que se refere este inciso fossem apenas em matéria cível, teria bastado o inquérito civil de que cuida o inc. III. O inquérito civil nada mais é que uma espécie de procedimento administrativo de atribuição ministerial. Mas o poder de requisitar informações e diligências não se exaure na esfera cível; atinge também a área destinada a investigações criminais ${ }^{\text {"448. }}$. No mesmo sentido é o posicionamento de AURY LOPES JR. ${ }^{449}$ e MARCELLUS POLASTRI LIMA ${ }^{450}$.

Colhem-se, porém, na doutrina, opiniões em contrário, como as de LUÍS GUILHERME VIEIRA, para quem o art. 129, VI, da Constituição Federal refere-se a

\footnotetext{
${ }^{448}$ Cf. Regime jurídico do Ministério Público, $5^{\text {a }}$ ed., São Paulo, Saraiva, 2001, pp. 439-440.

${ }^{449}$ Cf. Sistemas de investigação preliminar no processo penal, Rio de Janeiro, Lumen Juris, 2001, p. 143.

${ }^{450}$ Cf. O Ministério Público pode ou não investigar? Uma análise de recente decisão do STF, in Revista Brasileira de Ciências Criminais, nº 46, São Paulo, Revista dos Tribunais, janeiro-fevereiro de 2004, pp. 374375.
} 
“procedimentos administrativos conduzidos pelo Ministério Público, como o inquérito civil. Nessa hipótese, caso um Promotor de Justiça necessite de elementos de prova a instruir uma ação civil pública deverá fazer uso de seus poderes a fim de lograr obter informações e documentos. Diverso constitui o papel do Ministério Público nos casos de investigação por meio de inquérito policial. A lei, de fato, não contém palavras inúteis. Se assim não fosse, não teriam sido diferenciados os poderes dos órgãos ministeriais em incisos diferentes para situações diferentes" ${ }^{, 451}$.

Também com base na atribuição ao Ministério Público das funções de promover a ação penal pública ${ }^{452}$ e de requisitar diligências investigatórias, bem como a instauração de inquérito policial ${ }^{453}$, defendeu-se a constitucionalidade das investigações ministeriais. Afinal, o Parquet é o destinatário natural da instrução preliminar, e quem "pode o mais, pode o menos" (o mais, no caso, seria propor a ação penal, e o menos seria investigar).

Neste sentido, a teoria dos poderes implícitos ${ }^{454}$ costuma ser lembrada como argumento a corroborar a tese de que, embora a função investigatória não tenha sido atribuída expressamente ao Parquet na Constituição Federal de 1988, seria um instrumento ínsito, um meio necessário ao alcance das demais finalidades que lhe foram incumbidas,

${ }^{451}$ Cf. O Ministério Público e a investigação criminal in Revista Brasileira de Ciências Criminais, $\mathrm{n}^{\circ}$. 46, São Paulo, Revista dos Tribunais, janeiro-fevereiro de 2004, p. 340. Compartilham esse posicionamento MIGUEL REALE JR, O crime de desobediência e os processos investigatórios do Ministério Público in Boletim do Instituto Manoel Pedro Pimentel, $\mathrm{n}^{\mathrm{o}}$ 18, ano _ , outubro-novembro-dezembro de 2001, p. 10, e JOSÉ AFONSO DA SILVA, Em face da Constituição Federal de 1988, o Ministério Público pode realizar elou presidir investigação criminal, diretamente? in Revista Brasileira de Ciências Criminais, $\mathrm{n}^{\circ}$. 49, São Paulo, Revista dos Tribunais, julho-agosto de 2004, p. 386.

${ }^{452}$ Cf. DIEGO DINIZ RIBEIRO, A intervenção do Ministério Público na investigação criminal: a figura do promotor-investigador in Boletim do Instituto Brasileiro de Ciências Criminais, ano $10, \mathrm{n}^{\circ} 121$, dezembro de 2002, p. 11.

${ }^{453}$ Cf. ALOÍSIO FIRMO GUIMARÃES SILVA, MARIA EMILIA MORAES DE ARAÚJO e PAULO FERNANDO CORRÊA, A investigação criminal direta pelo Ministério Público in Boletim do Instituto Brasileiro de Ciências Criminais, ano 6, nº 66, maio de 1998, p. 251-252.

454 A teoria dos poderes implícitos foi formulada pela Suprema Corte americana no julgamento do caso MacCullogh vs. Maryland e estabelece que as Constituições, ao atribuírem determinadas finalidades a certos órgãos e entidades, implicitamente lhes conferem os meios, os poderes através dos quais serão atingidos os fins estabelecidos. Cf. PINTO FERREIRA, Comentários à Constituição Brasileira, vol. II, São Paulo, Saraiva, 1989, p. 132. Ainda sobre o tema, acrescenta MANOEL GONÇALVES FERREIRA FILHO que " $a$ tese dos "poderes implícitos" é uma construção da doutrina e da jurisprudência norte-americanas - os implied powers - a partir de uma Constituição sintética, a de 1787. Isto se fez para propiciar o reconhecimento, em favor de órgãos e entes constitucionais, de certos poderes instrumentais, necessários á consecução de determinadas tarefas ou objetivos, que lhes atribuía a Constituição". Cf. O poder investigatório do Ministério Público in Boletim do Instituto Manoel Pedro Pimentel, $\mathrm{n}^{\mathrm{o}}$ 23, dezembro de 2004, p. 03. Ressalva, porém, ALEXANDRE DE MORAES que os poderes implícitos decorrentes de missão constitucional podem ser exercidos pelos respectivos titulares desde que não expressamente limitados por outras funções previstas no mesmo diploma, ou seja, os aludidos poderes se sujeitam a proibições e limites estruturais da Constituição. Cf. Constituição do Brasil Interpretada e legislação constitucional, $7^{\mathrm{a}}$ ed., São Paulo. Atlas, 2007, p. 1717. 
em especial a de promover a ação penal. Defendem tal posicionamento AURY LOPES JR. $^{455}$ e HUGO NIGRO MAZZILLI ${ }^{456}$, para citar apenas alguns autores.

Há, no entanto, entendimentos dissonantes a este respeito: ADA PELLEGRINI GRINOVER, por exemplo, refuta a aplicação da teoria dos poderes implícitos à matéria, sob o argumento de que não haveria espaço no desenho constitucional para tanto. Por outro lado, a jurista sustenta que a Constituição teria aberto uma "válvula de escape" no art. 129, IX, a permitir as investigações criminais do Ministério Público ${ }^{457}$.

O referido dispositivo ${ }^{458}$ autoriza o Parquet a exercer funções diversas daquelas que lhe foram expressamente conferidas no texto constitucional, desde que compatíveis com sua finalidade. Segundo ADA PELLEGRINI GRINOVER, a realização da instrução preliminar é compatível com as demais funções do Parquet arroladas no art. 129 do diploma aludido, já que o Ministério Público é o destinatário das investigações, e o resultado destas não pode servir de base para a decisão de mérito, qualquer que seja o seu protagonista, pois os elementos são nelas colhidos sem o crivo do contraditório ${ }^{459}$.

Para JOSÉ AFONSO DA SILVA, no entanto, a teoria dos poderes implícitos não é aplicável à hipótese em análise, uma vez que inexiste relação de meio e fim entre a investigação criminal e a ação penal, além do que tal teoria só seria aplicável no silêncio da Constituição, e, no caso, a função de apurar o cometimento de delitos foi atribuída expressamente à polícia judiciária ${ }^{460}$. O jurista também é contrário ao uso da máxima "quem pode o mais, pode o menos" nas discussões sobre os poderes

\footnotetext{
${ }^{455}$ Cf. Sistemas de investigação preliminar no processo penal, Rio de Janeiro, Lumen Juris, 2001, p. 143.

${ }^{456}$ Cf. As investigações do Ministério Público para fins penais in Revista Magister de Direito Penal e Processual Penal, ano 1, $\mathrm{n}^{\circ}$ 5, 2005, p. 23.

${ }^{457}$ Cf. Investigações pelo Ministério Público in Boletim do Instituto Brasileiro de Ciências Criminais, ano $12, \mathrm{n}^{\mathrm{o}} 145$, dezembro de 2004, p. 04.

${ }^{458}$ Eis o teor integral do art. 129, IX, da Constituição Federal de 1988: “"Art. 129. São funções institucionais do Ministério Público: IX-exercer outras funções que lhe forem conferidas, desde que compativeis com sua finalidade, sendo-lhe vedada a representação judicial e a consultoria jurídica de entidades públicas".

${ }^{459}$ Cf. Investigações pelo Ministério Público in Boletim do Instituto Brasileiro de Ciências Criminais, ano 12, no 145 , dezembro de 2004, p. 04.

${ }^{460}$ Cf. Em face da Constituição Federal de 1988, o Ministério Público pode realizar elou presidir investigação criminal, diretamente? in Revista Brasileira de Ciências Criminais, $\mathrm{n}^{\circ}$ 49, São Paulo, Revista dos Tribunais, julho-agosto de 2004, pp. 376-377. No mesmo sentido é posicionamento de CEZAR ROBERTO BITTENCOURT, A inconstitucionalidade dos poderes investigatórios do Ministério Público in Revista Brasileira de Ciências Criminais, $\mathrm{n}^{\circ}$ 66, São Paulo, Revista dos Tribunais, maio-junho de 2007, p. 259, e RENATO STANZIOLA VIEIRA, Ainda, investigação criminal direta do Ministério Público: poder implícito ou limite explícito? Proposta de novo enfoque in Boletim do Instituto Brasileiro de Ciências Criminais, ano 17, nº 199, junho de 2009, p. 11.
} 
investigatórios criminais do Parquet, já que não se pode falar em "mais" e "menos" em matéria de competência ${ }^{461}$.

\section{Compartilham deste entendimento LUÍS GUILHERME VIEIRA ${ }^{462}$ e}

MAURÍCIO ZANÓIDE DE MORAES, para quem a atividade investigativa e a acusação judicial "não têm a mesma natureza jurídica e não estão postas de forma hierárquica pela qual a investigação seria o menos e a ação penal seria o mais. Não se pode confundir anterioridade com prevalência ou com intensidade. A investigação é anterior, não inferior à ação penal $" 463$.

MIGUEL REALE JR., além de refutar a aplicação do argumento "quem pode o mais pode o menos", observa que a realização de investigações criminais pelo Parquet pode levar à desestabilização da relação de igualdade existente entre acusação e defesa $^{464}$. Muitos são os juristas, aliás, a alertar para o risco de a investigação ministerial violar a igualdade processual e a paridade de $\operatorname{armas}^{465}$, ressaltando SÉRGIO MARCOS DE MORAES PITOMBO que a realização de investigações criminais pelo Parquet, mais do que desrespeitar aqueles princípios, compromete a própria imparcialidade da instituição, pois implica a busca orientada de prova, tendente a corroborar a versão da acusação sobre os fatos, desconsiderando eventuais informações que interessem ao envolvido ${ }^{466}$.

461 Cf. Em face da Constituição Federal de 1988, o Ministério Público pode realizar elou presidir investigação criminal, diretamente? in Revista Brasileira de Ciências Criminais, $\mathrm{n}^{\circ}$ 49, São Paulo, Revista dos Tribunais, julho-agosto de 2004, pp. 377-379.

${ }^{462}$ Segundo o autor, o adágio "quem pode o mais pode o menos" é um argumento falacioso invocado para justificar uma "pseudo-atribuição concorrente/supletiva" do Parquet de promover investigações criminais, pois enquanto os particulares podem fazer tudo que não lhes seja expressamente proibido, os órgãos e instituições públicas só podem fazer aquilo que lhes é expressamente permitido, ou seja, sua competência deve estar claramente prevista em lei. Cf. O Ministério Público e a investigação criminal in Revista Brasileira de Ciências Criminais, $n^{\circ}$. 46, São Paulo, Revista dos Tribunais, janeiro-fevereiro de 2004, p. 319.

463 Cf. Esgrimando com o professor Sérgio Marcos de Moraes Pitombo: os inexistentes poderes investigatórios criminais do Ministério Público in Revista do Advogado, $\mathrm{n}^{\mathrm{0}} 78$, ano XXIV, setembro de 2004, pp. 69-70.

${ }^{464}$ Cf. O crime de desobediencia e os processos investigatórios do Ministério Público in Boletim do Instituto Manoel Pedro Pimentel, $\mathrm{n}^{\mathrm{o}}$ 18, ano _, outubro-novembro-dezembro de 2001, p. 11.

${ }^{465}$ Entre tais autores, é possível mencionar ANTONIO EVARISTO DE MORAIS FILHO, O Ministério Público e o inquérito policial in Revista Brasileira de Ciências Criminais, $\mathrm{n}^{\circ}$ 19, São Paulo, Revista dos Tribunais, julho-setembro de 2007, p. 108, ROGÉRIO LAURIA TUCCI, Ministério Público e investigação criminal, São Paulo, Revista dos Tribunais, 2004, pp. 82-83, e GUILHERME DE SOUZA NUCCI, Manual de processo penal e execução penal, $2^{\mathrm{a}}$ ed., São Paulo, Revista dos Tribunais, 2006, p. 130.

${ }^{466}$ Cf. Procedimento administrativo criminal, realizado pelo Ministério Público in Boletim do Instituto Manoel Pedro Pimentel, no 22, ano V, junho-julho-agosto de 2003, p. 03. Defendem também tal posição LUÍS GUILHERME VIEIRA, O Ministério Público e a investigação criminal in Revista Brasileira de Ciências Criminais, $n^{\circ}$. 46, São Paulo, Revista dos Tribunais, janeiro-fevereiro de 2004, p. 314, JOSÉ CARLOS FRAGOSO, São ilegais os "procedimentos investigatórios" realizados pelo Ministério Público Federal in Revista Brasileira de Ciências Criminais, $n^{\circ}$. 37, São Paulo, Revista dos Tribunais, janeiro-março de 2002, p. 242, ORLANDO MIRANDA FERREIRA, Inquérito policial e o Ato Normativo 314 - PGJ/CPJ in Revista Brasileira de Ciências Criminais, $n^{\circ}$. 45, São Paulo, Revista dos Tribunais, outubro-dezembro de 
Há, no entanto, vários autores a sustentar que as investigações ministeriais não violam o equilíbrio processual nem a paridade de armas, fundamentalmente porque o Ministério Público, como parte no processo penal, não precisa agir imparcialmente. Para AURY LOPES JR., “o argumento da imparcialidade do Ministério Público é uma frágil construção técnica facilmente criticável, pois é contrário à lógica pretender a imparcialidade de uma parte. Ademais, é absolutamente inconciliável que uma mesma pessoa investigue e acuse e ainda seja defendida sua imparcialidade ${ }^{, 467}$.

Neste ponto, mostra-se oportuno realizar uma pequena digressão acerca das discussões sobre a qualificação do Ministério Público como parte no processo penal.

Colhem-se na doutrina opiniões tanto no sentido de que o Parquet seria uma parte instrumental ${ }^{468}$, como o de que seria uma parte imparcial ${ }^{469}$, uma parte em sentido puramente formal $^{470}$, ou até mesmo uma parte sui generis, posição esta defendida por FRANCESCO CARNELUTTI, que se refere ainda ao Parquet como parte imprópria ou artificial, não natural ${ }^{471}$.

O fato de atribuir-se ao Ministério Público tanto a função acusatória no processo penal, como o dever de atuar como fiscal da lei, é uma das principais causas de todas as controvérsias em torno da qualificação do Parquet. Isto porque, na condição de custos legis, cabe ao Ministério Público zelar pela correta aplicação da lei, podendo, nesse

2003, p. 263, e NELIO ROBERTO SEIDL MACHADO, Notas sobre a investigação criminal, diante da estrutura do processo criminal no estado de direito democrático in Discursos sediciosos - Crime, direito e sociedade, vol. 3, no 5/6, Rio de Janeiro, Freitas Bastos, 1998, p. 153.

${ }^{467}$ Cf. Sistemas de investigação preliminar no processo penal, Rio de Janeiro, Lumen Juris, 2001, p. 89.

${ }^{468}$ Esta tese é defendida, entre outros autores, por FERNANDO DA COSTA TOURINHO FILHO, Processo Penal, vol. II, $18^{\mathrm{a}}$ ed., São Paulo, Saraiva, 1997, pp. 352-355.

${ }^{469}$ EDGAR MAGALHÃES NORONHA afirma ser o Parquet parte dotada de imparcialidade in Curso de direito processual penal, $27^{\mathrm{a}}$ ed., São Paulo, Saraiva, 1999, p. 179. No mesmo sentido o posicionamento de JORGE DE FIGUEIREDO DIAS, Direito processual penal, __ ed., Coimbra, Coimbra Editora, 2004, p. 369, e PAULO CEZAR PINHEIRO CARNEIRO, O Ministério Público no processo civil e penal: promotor natural - atribuição e conflito, Rio de Janeiro, Forense, 1995, p. 248. ROGÉRIO LAURIA TUCCI, apesar de sustentar ser o Ministério Público uma parte em sentido processual, também ressalva a posição sui generis da instituição, decorrente de sua atuação não apenas como órgão acusatório, mas também como órgão opinante. Cf. Teoria do direito processual penal - Jurisdição, ação e processo penal (estudo sistemático), São Paulo, Revista dos Tribunais, 2002, p. 187.

${ }^{470}$ Cf. VINCENZO MANZINI, Tratado de derecho procesal penal, vol. 2, Buenos Aires, Ediciones Jurídicas Europa-América, 1951, p. 314. No mesmo sentido, sustenta JOÃO LOPES GUIMARÃES que o Ministério Público não é parte na relação jurídica material, mas apenas na relação jurídica processual, por conta de sua atuação como órgão fiscalizador. Cf. A posição do Ministério Público na fase pré-processual e o projeto do código de processo penal in Revista Justitia, v. 60, nº especial, 1999, p. 633.

${ }^{471}$ Cf. Principi del processo penale, Napoli, Morano Editore, 1960, p. 42. Também para HELIO TORNAGHI a duplicidade de funções do Parquet fez dele uma parte sui generis. Cf. Comentários ao Código de Processo Penal, Rio de Janeiro, Revista Forense, 1956, p. 486. 
sentido, até mesmo postular a absolvição de um acusado ${ }^{472}$. Esta duplicidade de funções levou JORGE DE FIGUEIREDO DIAS a questionar-se se não seria "puro idealismo utópico pretender que o MP cumpra simultaneamente a sua função de acusador e de sujeito processual dotado de absoluta imparcialidade ${ }^{, 473}$.

Nos Estados Unidos, por exemplo, os membros do Parquet não exercem a função de fiscal da lei, enquanto nos países de tradição continental, o Ministério Público costuma ser incumbido não apenas da função de acusar mas também da de fiscalizar a observância ao ordenamento jurídico em suas diferentes esferas ${ }^{474}$. Esta dupla atribuição de funções é que costuma gerar o entendimento de que o Ministério Público é uma parte imparcial no processo penal ${ }^{475}$, pois é guiado pelo interesse público de buscar a verdade e de aplicar corretamente a lei, além do que deve atuar com isenção e almejar sempre a promoção da justiça ${ }^{476}$, ainda que isto implique a absolvição do acusado.

Há, no entanto, quem sustente ser o Parquet uma efetiva parte no processo penal $^{477}$, bem como que é incompatível com o sistema acusatório a idéia de imparcialidade da instituição ${ }^{478}$, pois aquele prima justamente pela existência do contraditório, onde partes com interesses distintos atuam em igualdade de condições, numa estrutura dialética eficiente para a busca da verdade.

GUSTAVO HENRIQUE IVAHY BADARÓ, por exemplo, é defensor ardoroso da parcialidade do Parquet, tanto pelas razões expostas como pela constatação de que, na prática, a instituição visa sempre a comprovar sua hipótese delitiva, não o contrário, o que é não só natural como salutar num processo penal de partes como pretende ser o acusatório. Nas palavras do próprio autor, “o Ministério Público no processo penal é parte, parte interessada. Ao formular a acusação, embora esteja buscando o acertamento

${ }^{472}$ Cf. ANTONIO MAGAlHÃES GOMES FILHO, Ministério Público e acusação penal no sistema brasileiro in Ministério Público - Pena y Estado, Buenos Aires, Editores del Puerto, 1997, p. 151.

${ }^{473}$ Cf. Direito processual penal, Coimbra, Coimbra Editora, 2004, p. 369.

${ }^{474}$ Cf. DENISE NEVES ABADE, Garantias do processo penal acusatório - O novo papel do Ministério Público no processo penal de partes, Rio de Janeiro, Renovar, 2005, pp. 29-53.

${ }^{475}$ Cf. JULIO FABBRINI MIRABETE, Código de processo penal interpretado, $11^{\mathrm{a}}$ ed., São Paulo, Atlas, 2006 , p. 359.

${ }^{476}$ Cf. MARCO ANTONIO DE BARROS, A busca da verdade no processo penal, Revista dos Tribunais, São Paulo, 2002, p. 154.

${ }^{477}$ Cf. ANIELLO NAPPI, Guida breve alla procedura penale, $2^{\mathrm{a}}$ ed., Milano, Giuffrè, 2004, p. 15 e 20, e GIOVANNI CONSO e VITTORIO GREVI, Compendio di procedura penale: appendice di aggiornamento,

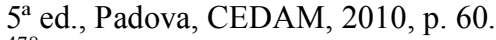

${ }^{478}$ Para AURY LOPES JR., a imparcialidade do Parquet "só é alardeada por quem não sabe o que fala. Por quem não sabe o que é imparcialidade e desconhece a origem do Ministério Público (que nasce como contraditor natural do imputado e imposição do sistema acusatório)". Cf. A opacidade da discussão em torno do promotor investigador (mudem os inquisidores, mas a fogueira continuará acesa) in Boletim do Instituto Brasileiro de Ciências Criminais, ano 12, no 142, setembro de 2004, pp. 10-11. 
judicial sobre a ocorrência ou não do fato crime imputado ao acusado, o Ministério Público já se convenceu previamente da culpabilidade e buscará prová-la. Embora para o exercício da ação penal não se exija a certeza da autoria, o representante do Ministério Público, quando acusa, certamente entende que esta é a hipótese mais provável. Mais do que isso, ao oferecer a denúncia, o promotor de Justiça acredita que, ao cabo da instrução, conseguirá provar, além de qualquer dúvida razoável, a tese da acusação"479.

Respeitados os entendimentos em contrário, de fato tem-se que o reconhecimento da parcialidade do Ministério Público mostra-se mais consentâneo com o sistema acusatório e com a idéia de um processo penal efetivamente de partes, onde estas possam atuar em igualdade de condições e tentar fazer valer seus interesses contrapostos, numa relação dialética que só contribui para o melhor esclarecimento do fato penal típico ocorrido e demais circunstâncias relevantes.

O fato de o Parquet poder pleitear a absolvição do réu ao final do processo, impetrar habeas corpus ou recorrer em favor do acusado, de modo algum desnatura sua verdadeira condição de parte ${ }^{480}$, pois, durante toda a persecução penal, atua como órgão acusatório. Sobre o assunto, sustenta MARCOS ALEXANDRE COELHO ZILLI que "não há como se conceber o Ministério Público, no exercício da ação penal condenatória, como um sujeito imparcial. Os sujeitos parciais são aqueles que direcionam o seu movimento ao longo da marcha processual de acordo com uma afirmação. Ou acusatória, como o Ministério Público, ou defensiva, como o acusado. Não está equiparado ao juiz. Este sim verdadeira e necessariamente imparcial, porquanto não comprometido, objetiva ou subjetivamente, com qualquer afirmação. Aliás, a possibilidade de pleitear, a final, uma absolvição não desnatura o movimento original que é o de promover e, portanto, sustentar a ação penal",481.

Caso após a instrução probatória reste demonstrada a inocência do acusado, é dever do Ministério Público, como instituição do Estado e que deve observar imperativos legais e éticos, pleitear sua absolvição, a fim de que um inocente não acabe injustamente condenado. Isso não implica, porém, afirmar que o Parquet é uma parte imparcial, pois durante toda a persecução penal atuou como órgão da acusação. Recorde-se, neste ponto,

\footnotetext{
${ }^{479}$ Cf. Ônus da prova no processo penal, São Paulo, Revista dos Tribunais, 2003, p. 220.

${ }^{480}$ Para JOSÉ FREDERICO MARQUES, esse argumento reforça a qualidade de parte do Parquet, não a desnatura, até porque se a instituição fosse imparcial, não seria necessária a figura do juiz para decidir a causa. Cf. Elementos de Direito Processual Penal, vol. II, $2^{\mathrm{a}}$ ed., Campinas, Millenium, 2000, p. 41.

${ }^{481} \mathrm{Cf}$. Atuação investigatória do Ministério Público: um convite à reflexão in Boletim do Instituto Manoel Pedro Pimentel, nº 23, dezembro de 2004, p. 07.
} 
que a instrução prévia não serve apenas para obter os elementos necessários à propositura de uma ação penal, mas também para evitar acusações equivocadas e infundadas que só prejudicariam o investigado.

Aliás, a apontada tendência de o Ministério Público proceder a uma busca orientada por fontes de provas durante a instrução preliminar, tendente a corroborar a versão acusatória sobre o fato criminoso e suas circunstâncias, não deve constituir óbice à realização de investigações pelo Parquet, primeiro porque, como visto, a atividade nada mais consiste do que no exercício do direito à investigação, de que é titular também o possível acusado numa futura ação penal. O fato de tal direito ser atribuído a ambas eventuais partes em um processo penal assegura o equilíbrio necessário entre as mesmas, sua paridade de armas e a própria igualdade que orienta todo processo penal.

Além disso, é evidente que, tomando ciência o Ministério Público de fatos que beneficiem o investigado, não os descartará, devendo levá-los em consideração até por força dos imperativos legais a que se sujeita.

E são dignas de nota algumas das decisões das mais altas cortes deste País no sentido de que o Ministério Público é uma verdadeira parte no processo penal. Em julgamento realizado no ano de 2008, o Pleno do Supremo Tribunal Federal decidiu que "ainda que, no mérito, o Ministério Público postule a absolvição do acusado, continua sempre órgão incumbido da acusação e não deixa de agir ou de poder agir como parte que é. Conclusão diversa levaria à concepção de processo de parte única, o acusado, o que parece absurdo diante de um sistema garantista, acusatório, antagônico, marcado pela garantia da contraditoriedade ${ }^{482}$. Também deve ser lembrada a recente decisão do C. Superior Tribunal de Justiça que igualmente reconheceu a natureza de efetiva parte do Parquet. No referido decisum, asseverou-se que "o Ministério Público é parte no processo penal, e embora seja entidade vocacionada à defesa da ordem jurídica, representando a sociedade como um todo, não atua de forma imparcial no âmbito penal "483.

E, a esta discussão sobre a qualificação do Parquet em nosso ordenamento jurídico, acrescenta-se a previsão da Súmula 234 do Superior Tribunal de Justiça, segundo a qual "a participação de membro do Ministério Público na fase investigatória criminal não acarreta o seu impedimento ou suspeição para o oferecimento de denúncia”. A

${ }^{482}$ Cf. STF, HC n ${ }^{\text {o }}$ 87.926/SP, Rel. Min. Cezar Peluso, Pleno, julgado em 20.02.2008.

${ }^{483}$ Cf. STJ, HC n ${ }^{\circ}$ 154.093/RJ, Rel. Min. Jorge Mussi, Quinta Turma, julgado em 09.11.2010. 
Súmula é interpretada de maneira absolutamente diversa pelos opositores e defensores das investigações criminais do Parquet ${ }^{484}$.

Seja como for, no que diz respeito à polêmica em torno de a Constituição Federal de 1988 ter atribuído ou não ao Parquet a função de investigar crimes, é possível afirmar que, embora não o tenha feito expressamente, o texto constitucional autorizou o Ministério Público a realizar instrução criminal prévia, conclusão esta que decorre tanto da asseguração pela Carta vigente do direito à prova como da previsão do art. 129, IX do diploma, que permite ao Ministério Público exercer atividades diversas das ali previstas expressamente, desde que compatíveis com sua finalidade.

O referido inciso IX do art. 129 da Constituição Federal constitui uma verdadeira cláusula de encerramento acerca das funções institucionais do Parquet, pois permite a este exercer atribuições diversas daquelas arroladas especificamente no art. 129, desde que condizentes com seus fins. E, como já visto, o exercício de atividade investigativa é plenamente compatível com o escopo de atuação do Ministério Público.

Se no plano constitucional, o exercício do direito à investigação pelo Parquet já gera inúmeras controvérsias, no plano infraconstitucional não seria diferente. Diversas normas concernentes ao tema têm dispositivos que são fonte de intensas discussões jurídicas e de interpretações completamente díspares.

O Código de Processo Penal (Decreto-lei $n^{0} 3.931 / 41$ ) trata da fase inicial da persecução penal basicamente no Livro I, Título II, do diploma, arts. $4^{\circ}$ a 23 . Entre estes, apresenta inegável importância para o tema o já referido art. $4^{\circ}$, cujo caput estabelece que a atuação da polícia judiciária deve se dar nos limites territoriais de suas circunscrições e tendo por finalidade precípua a investigação da materialidade e autoria dos delitos cometidos. O parágrafo único do dispositivo é que causa as maiores polêmicas ao estatuir que a atribuição da polícia judiciária referida no caput não exclui a de outras autoridades administrativas, a quem por lei seja cometida a mesma função.

Esta previsão legal é utilizada tanto para fundamentar as investigações criminais do Parquet como para refutá-las. Muitos juristas não negam a existência e

${ }^{484}$ Para MAURÍCIO ZANÓIDE DE MORAES, por exemplo, a participação referida na Súmula consistiria na requisição de diligências e controle externo da atividade policial, não na realização de investigações criminais. Cf. Esgrimando com o professor Sérgio Marcos de Moraes Pitombo: os inexistentes poderes investigatórios criminais do Ministério Público in Revista do Advogado, $\mathrm{n}^{\circ} 78$, ano XXIV, setembro de 2004, p. 70. Já para PAULO GUSTAVO GUEDES FONTES, a mesma Súmula corrobora a assertiva de que o Ministério Público é parte no processo penal. Cf. O poder investigatório do Ministério Público in Boletim Científico ESMPU, ano II, no 8, Brasília, ESMPU, julho-setembro de 2006, p. 135. 
admissibilidade de modalidades de investigação diversas do inquérito policial ${ }^{485}$, no entanto, defendem que este dispositivo não é aplicável ao Ministério Público ${ }^{486}$. Mas há inúmeros defensores da tese de que o art. $4^{\circ}$ do Código de Processo penal, na esteira do texto constitucional, permite ao Parquet realizar investigações criminais ${ }^{487}$.

Os artigos $27,39, \S 5^{\circ}$, e 46 do referido diploma ${ }^{488}$, ao aludirem à dispensabilidade do inquérito policial, também costumam ser lembrados como argumentos favoráveis à tese de que o Parquet pode investigar crimes ${ }^{489}$.

Os juristas contrários à realização de atos de instrução preliminar pelo Ministério Público não negam que as hipóteses legais referidas autorizam a dispensa do inquérito policial, mas entendem que as mesmas não autorizam as investigações ministeriais $^{490}$.

${ }^{485}$ Neste sentido é o posicionamento de EDUARDO LUIZ SANTOS CABETTE. Cf. O papel do inquérito policial no sistema acusatório - o modelo brasileiro in Revista Brasileira de Ciências Criminais, $\mathrm{n}^{\circ}$. 35, São Paulo, Revista dos Tribunais, julho-setembro de 2001, p. 191.

${ }^{486}$ LUÍS GUILHERME VIEIRA resume bem o posicionamento dessa corrente de pensamento, ao afirmar que ao Parquet é vedado "utilizar-se da regra estatuida no par. ún. do art. $4^{\circ}$ do CPP, recepcionada pela Carta de 1988, para, tomando-a como "pseudo-atribuição concorrente/supletiva" à polícia judiciária, investigar crimes, posto que a ressalva introduzida pelo legislador de 1940 é aplicada, sim, ao órgão ministerial, mas, única e exclusivamente, nos fatos de poder-dever investigar os praticados por seus representantes". Cf. O Ministério Público e a investigação criminal in Revista Brasileira de Ciências Criminais, $n^{\circ}$. 46, São Paulo, Revista dos Tribunais, janeiro-fevereiro de 2004, p. 332.

${ }^{487}$ Esta é a posição sustentada por MARCELLUS POLASTRI LIMA, O Ministério Público pode ou não investigar? Uma análise de recente decisão do STF, in Revista Brasileira de Ciências Criminais, $\mathrm{n}^{\circ}$ 46, São Paulo, Revista dos Tribunais, janeiro-fevereiro de 2004, p. 377, JOSÉ BARCELOS DE SOUZA' Investigação direta pelo Ministério Público in Revista Brasileira de Ciências Criminais, $\mathrm{n}^{\circ}$. 44, São Paulo, Revista dos Tribunais, julho-setembro de 2003, p. 365, entre outros.

${ }^{488}$ Estabelecem os referidos dispositivos o seguinte: "Art. 27. Qualquer pessoa do povo poderá provocar a iniciativa do Ministério Público, nos casos em que caiba a ação pública, fornecendo-lhe, por escrito, informações sobre o fato e a autoria e indicando o tempo, o lugar e os elementos de conviç̧ão".

"Art. 39. $\S 5^{\circ} \mathrm{O}$ órgão do Ministério Público dispensará o inquérito, se com a representação forem oferecidos elementos que o habilitem a promover a ação penal, e, neste caso, oferecerá a denúncia no prazo de quinze dias".

"Art. 46. § $1^{\circ}$ Quando o Ministério Público dispensar o inquérito policial, o prazo para o oferecimento da denúncia contar-se-á da data em que tiver recebido as peças de informações ou a representação".

${ }^{489}$ Nesse sentido, veja-se SERGIO DEMORO HAMILTON, A amplitude das atribuições do Ministério Público in Discursos sediciosos - Crime, direito e sociedade, vol. 3, $\mathrm{n}^{\circ}$ 5/6, Rio de Janeiro, Freitas Bastos, 1998, pp. 140-141, CARLOS FREDERICO COELHO NOGUEIRA, O Ministério Público pode investigar delitos in Boletim do Instituto Manoel Pedro Pimentel, $\mathrm{n}^{\circ}$ 21, ano IV, julho-agosto-setembro de 2002, p. 20, e VALTER FOLETO SANTIN, O Ministério Público na investigação criminal, Bauru, Edipro, 2001, p. 242. E, ao tratar do assunto, DIEGO DINIZ RIBEIRO formula a seguinte indagação: "se o inquérito policial é dispensável para o oferecimento de denúncia, por que não pode o titular da ação penal pública valer-se de um procedimento investigatório, de cunho administrativo e por ele dirigido, que não o inquérito policial, para propor a pertinente ação penal?". Cf. A intervenção do Ministério Público na investigação criminal: a figura do promotor-investigador in Boletim do Instituto Brasileiro de Ciências Criminais, ano 10, $\mathrm{n}^{\circ}$ 121, dezembro de 2002, p. 11.

${ }^{490}$ Neste sentido é a opinião de MAURÍCIO ZANÓIDE DE MORAES, Esgrimando com o professor Sérgio Marcos de Moraes Pitombo: os inexistentes poderes investigatórios criminais do Ministério Público in Revista do Advogado, $\mathrm{n}^{\circ}$ 78, ano XXIV, setembro de 2004, p. 70, CEZAR ROBERTO BITTENCOURT, $A$ inconstitucionalidade da Resolução $n^{o} 13$ do Conselho Nacional do Ministério Público in Boletim do 
Em suma, respeitados os entendimentos em contrário, em relação ao tratamento conferido pelo Código de Processo Penal à investigação criminal, é possível afirmar que o art. $4^{\circ}$ do diploma só vem corroborar a conclusão já extraída da análise da Constituição Federal de 1988 de que a polícia não detém a exclusividade da função investigatória. E os artigos 27, 39, $\S 5^{\circ}$, e 46 do Código de Processo Penal apenas evidenciam que o inquérito policial é dispensável quando a acusação já dispuser das informações necessárias à propositura da ação penal.

É imperioso ainda mencionar que, além do Código de Processo Penal, outras leis contêm importantes previsões relacionadas aos poderes investigatórios do Ministério Público, entre elas a Lei $n^{\circ}$ 8.625/93 (Lei Orgânica Nacional do Ministério Público/LONMP) e a Lei Complementar $n^{\circ}$ 75/93 (Estatuto do Ministério Público da União).

A Lei $n^{\circ} 8.625 / 93$ tem no seu art. 26 uma fonte infindável de controvérsias, pois o inciso I do dispositivo autoriza o Parquet a instaurar inquéritos civis e outras medidas e procedimentos pertinentes, ao passo que o inciso IV permite à instituição requisitar diligências investigatórias e a instauração de inquérito policial e de inquérito policial militar ${ }^{491}$.

Os opositores de tal forma de instrução preliminar acreditam que o inciso I do dispositivo não permite a realização de investigações criminais, mas meramente cíveis $^{492}$, e que o inciso IV não incluiu a atividade entre as atribuições institucionais do Parquet ${ }^{493}$.

Instituto Brasileiro de Ciências Criminais, ano 14, $\mathrm{n}^{\circ}$ 170, janeiro de 2007, p. 11, e JOSÉ AFONSO DA SILVA. Ao tratar do assunto, o autor inicialmente ressalva que o inquérito policial não é facultativo, mas apenas "dispensável, quando a notitia criminis consta de algum procedimento ou documentos com elementos suficientes para a propositura da ação penal", para depois afirmar que tal dispensabilidade se dá através da apuração indireta de delitos, por exemplo, quando estes são verificados no curso de um processo administrativo. Cf. Em face da Constituição Federal de 1988, o Ministério Público pode realizar elou presidir investigação criminal, diretamente? in Revista Brasileira de Ciências Criminais, $\mathrm{n}^{\circ}$. 49, São Paulo, Revista dos Tribunais, julho-agosto de 2004, pp. 381-382.

${ }^{491}$ Eis o dispositivo: "Art. 26. No exercício de suas funções, o Ministério Público poderá: I - instaurar inquéritos civis e outras medidas e procedimentos pertinentes (...); IV-requisitar diligências investigatórias e a instauração de inquérito policial e de inquérito policial militar, observado o disposto no art. 129, VIII, da Constituição Federal, podendo acompanhá-los".

${ }^{492}$ Nesse sentido, a opinião de MIGUEL REALE JR., $O$ crime de desobediência e os processos investigatórios do Ministério Público in Boletim do Instituto Manoel Pedro Pimentel, $\mathrm{n}^{\circ} 18$, ano outubro-novembro-dezembro de 2001, p. 10, ORLANDO MIRANDA FERREIRA, Inquérito policial e o Ato Normativo $314-P G J / C P J$ in Revista Brasileira de Ciências Criminais, $\mathrm{n}^{\circ}$. 45, São Paulo, Revista dos Tribunais, outubro-dezembro de 2003, p. 264, e JOSÉ AFONSO DA SILVA, para quem o art. 26, I, da Lei $\mathrm{n}^{\mathrm{o}}$ 8.625/93 apenas "autoriza o Ministério Público, no exercício de suas funções, a instaurar inquéritos civis e outras medidas e procedimentos administrativos pertinentes, e todo o conteúdo de suas alineas é 
Em sentido oposto, há quem sustente que as funções penais do Parquet previstas no ar. 26 da Lei $n^{\circ}$ 8.625/93 não se limitam às do inciso IV do dispositivo, abrangendo as dos demais incisos também ${ }^{494}$.

Também suscita controvérsias a Lei Complementar $n^{\circ} 75 / 93$, que regula o Ministério Público da União, mas tem suas disposições aplicadas subsidiariamente aos Ministérios Públicos dos Estados, nos termos do art. 80 do diploma. Os arts. $7^{\circ}, 8^{\circ}$ e 38 do referido ato normativo se relacionam ao tema, pois tratam justamente das funções atribuídas à instituição ${ }^{495}$.

À semelhança do que se viu em relação ao art. 26 da Lei $n^{\circ} 8.625 / 93$, os dispositivos da Lei Complementar $n^{\circ} 75 / 93$ costumam ser interpretados de maneiras diversas pelos defensores e opositores da realização de investigações criminais pelo

tipicamente administrativo, ou refere-se a procedimentos tais como a sindicância administrativa, o inquérito administrativo e o processo administrativo, e se destina a apurar infrações disciplinares e eventual aplicação de sanções administrativas". Cf. Em face da Constituição Federal de 1988, o Ministério Público pode realizar elou presidir investigação criminal, diretamente? in Revista Brasileira de Ciências Criminais, $\mathrm{n}^{\mathrm{o}}$. 49, São Paulo, Revista dos Tribunais, julho-agosto de 2004, p. 385.

${ }^{493}$ Cf. LUÍS GUILHERME VIEIRA, O Ministério Público e a investigação criminal in Revista Brasileira de Ciências Criminais, nº. 46, São Paulo, Revista dos Tribunais, janeiro-fevereiro de 2004, pp. 343-344.

${ }^{494}$ Tal é a opinião dos juristas AURY LOPES JR., Sistemas de investigação preliminar no processo penal, Rio de Janeiro, Lumen Juris, 2001, p. 142, e MARCELLUS POLASTRI LIMA, O Ministério Público pode ou não investigar? Uma análise de recente decisão do STF, in Revista Brasileira de Ciências Criminais, $\mathrm{n}^{\circ}$ 46, São Paulo, Revista dos Tribunais, janeiro-fevereiro de 2004, p. 385.

${ }^{495}$ Eis o conteúdo dos referidos dispositivos legais: "Art. $7^{\circ}$ Incumbe ao Ministério Público da União, sempre que necessário ao exercício de suas funções institucionais: I - instaurar inquérito civil e outros procedimentos administrativos correlatos; II - requisitar diligências investigatórias e a instauração de inquérito policial e de inquérito policial militar, podendo acompanhá-los e apresentar provas; III requisitar à autoridade competente a instauração de procedimentos administrativos, ressalvados os de natureza disciplinar, podendo acompanhá-los e produzir provas."

"Art. $8^{\circ}$ Para o exercicio de suas atribuições, o Ministério Público da União poderá, nos procedimentos de sua competência: I - notificar testemunhas e requisitar sua condução coercitiva, no caso de ausência injustificada; II - requisitar informações, exames, perícias e documentos de autoridades da Administração Pública direta ou indireta; III - requisitar da Administração Pública serviços temporários de seus servidores e meios materiais necessários para a realização de atividades específicas; IV - requisitar informações $e$ documentos a entidades privadas; $V$ - realizar inspeções e diligências investigatórias; VI - ter livre acesso a qualquer local público ou privado, respeitadas as normas constitucionais pertinentes à inviolabilidade do domicílio; VII - expedir notificações e intimações necessárias aos procedimentos e inquéritos que instaurar; VIII - ter acesso incondicional a qualquer banco de dados de caráter público ou relativo a serviço de relevância pública; $I X$ - requisitar o auxílio de força policial.(...)”

"Art. 38. São funções institucionais do Ministério Público Federal as previstas nos Capitulos I, II, III e IV do Título I, incumbindo-lhe, especialmente: I - instaurar inquérito civil e outros procedimentos administrativos correlatos; II - requisitar diligências investigatórias e instauração de inquérito policial, podendo acompanhá-los e apresentar provas; III - requisitar à autoridade competente a instauração de procedimentos administrativos, ressalvados os de natureza disciplinar, podendo acompanhá-los e produzir provas; IV - exercer o controle externo da atividade das policias federais, na forma do art. $9^{\circ}$; $V$ - participar dos Conselhos Penitenciários; VI - integrar os órgãos colegiados previstos no $\S 2^{\circ}$ do art. $6^{\circ}$, quando componentes da estrutura administrativa da União; VII - fiscalizar a execução da pena, nos processos de competência da Justiça Federal e da Justiça Eleitoral." 
Ministério Público. Para alguns ${ }^{496}$, segundo o diploma em análise, o Ministério Público só pode requisitar diligências investigatórias e a instauração de inquérito policial e de inquérito policial militar, e acompanhar e apresentar provas, na seara penal. Mas há quem enxergue nos mesmos dispositivos autorizações legais para a realização de investigações criminais pelo Parquet ${ }^{497}$. Para DENILSON FEITOZA PACHECO, por exemplo, esses e outros dispositivos de atos normativos relativos ao Ministério Público na verdade não criam novas faculdades, poderes ou direitos ao Parquet, apenas regulamentam seus procedimentos investigatórios ${ }^{498}$.

$\mathrm{Na}$ verdade, uma leitura atenta e minuciosa dos dispositivos mencionados da Lei $n^{\circ} 8.625 / 93$ e da Lei Complementar $n^{\circ} 75 / 93$ permite concluir que em nenhum deles aludiu-se expressamente à realização direta de atos de instrução preliminar pelo Parquet no âmbito penal. Tal circunstância, porém, não impede o exercício do direito à investigação pela instituição, assegurado pela Constituição Federal de 1988 em normas de eficácia plena.

Mencione-se ainda que leis complementares estaduais reguladoras do Ministério Público igualmente possuem dispositivos que tratam das funções da instituição no âmbito cível e criminal, e costumam ser lembradas para corroborar ou infirmar a atividade investigativa ministerial. A Lei Complementar $n^{\circ}$ 734/93 do Estado de São Paulo e a Lei Complementar $n^{\circ}$ 106/03 do Estado do Rio de Janeiro, por exemplo, arrolam funções do Ministério Público, respectivamente, nos arts. 103 e 35 e seguintes dos diplomas, mas tampouco atribuem claramente à instituição a prerrogativa de realizar atos investigatórios.

Justamente por conta da falta de autorização legal expressa para o exercício do direito à investigação, seja na Constituição Federal, seja no Código de Processo Penal ou em outras normas infraconstitucionais, o Ministério Público editou alguns atos normativos a fim de dar maior legitimidade às diligências promovidas nessa seara. $\mathrm{O}$ primeiro deles foi o Ato $n^{\circ}$ 98/96 do Procurador-Geral de Justiça de São Paulo (Ato $n^{\circ}$

\footnotetext{
496 Por exemplo, MIGUEL REALE JR., O crime de desobediencia e os processos investigatórios do Ministério Público in Boletim do Instituto Manoel Pedro Pimentel, $\mathrm{n}^{\mathrm{o}} 18$, ano _, outubro-novembrodezembro de 2001, pp. 09-10.

${ }^{497}$ Compartilham tal entendimento, entre outros, AURY LOPES JR., Sistemas de investigação preliminar no processo penal, Rio de Janeiro, Lumen Juris, 2001, p. 145, e MARCELLUS POLASTRI LIMA, $O$ Ministério Público pode ou não investigar? Uma análise de recente decisão do STF, in Revista Brasileira de Ciências Criminais, n 46, São Paulo, Revista dos Tribunais, janeiro-fevereiro de 2004, pp. 385-386.

${ }^{498}$ Cf. Investigação criminal pelo Ministério Público in Boletim do Instituto de Ciências Penais, vol. 4, $\mathrm{n}^{\circ}$ 60, 2005, p. 07.
} 
98/96 - CPJ), que, a pretexto de estabelecer "normas para o controle externo da atividade de Polícia Judiciária do Ministério Público", previu em seu art. 26 os chamados procedimentos administrativos criminais do Parquet $^{499}$.

Este ato normativo foi alvo de intensas críticas, pois o Órgão Especial do Colégio de Procuradores do Ministério Público não teria competência para legislar sobre o controle externo da polícia judiciária, e suas previsões extrapolariam os limites fixados na Constituição e na Lei Complementar Estadual n $n^{\mathrm{o}} 734 / 93^{500}$. Segundo JOSÉ AFONSO DA SILVA, o Ato $\mathrm{n}^{\circ}$ 98/96 - CPJ tem vários dispositivos inconstitucionais, em especial o referido art. $26^{501}$.

Em 2003, a fim de regulamentar o procedimento administrativo criminal previsto no art. 26 do Ato n 98/96 - CPJ, o Ministério Público formulou o Ato Normativo 314-PGJ/CPJ, o qual foi também bastante criticado por apresentar como uma de suas motivações a prevenção da criminalidade, prever o arquivamento do procedimento administrativo sem o conhecimento do Poder Judiciário ${ }^{502}$, não ser a espécie normativa adequada à regulação da matéria, criar regras de direito processual penal, entre tantas outras $^{503}$.

Em tempos mais recentes, o Conselho Nacional do Ministério Público editou a Resolução $n^{\circ}$ 13/06, com vistas a regulamentar o art. 26 da Lei $n^{\circ} 8.625 / 93$ e o art. $8^{\circ}$ da Lei Complementar $n^{\circ} 75 / 93$, já referidos. O ato normativo também teve sua constitucionalidade questionada, ao argumento de que não estaria a regulamentar, mas sim a atribuir poderes investigatórios ao Ministério Público, violando o art. 22, I da

\footnotetext{
${ }^{499}$ Eis o dispositivo: “Art. 26. O órgão do Ministério Público poderá promover diretamente investigações, por meio de procedimento administrativo próprio a ser definido em Ato do Procurador-Geral de Justiça, ouvido o Colégio de Procuradores de Justiça”.

${ }^{500}$ Cf. ABRAHÃO JOSÉ KFOURI FILHO, Parecer in Revista ADPESP (Associação dos Delegados de Polícia do Estado de São Paulo), ano 17, no 22, São Paulo, dezembro de 1996, p. 46.

${ }^{501}$ Segundo o jurista, "nesse dispositivo, institui o Ministério Público sponte própria, particular forma de inquérito, extrapolando os limites, consignados em lei, que lhe permitem cancelar investigação, o que só é possivel nas hipóteses de infração penal praticada por Promotores de Justiça, ou nos casos de inquérito civil, como medida preliminar à propositura de ação civil pública". Cf. Parecer "Controle externo da atividade policial como uma das funções institucionais do Ministério Público - entendimento do art. 129, VII, da Constituição Federal - conteúdo da Lei Complementar e seus limites constitucionais - competências exclusivas das polícias" in Revista ADPESP (Associação dos Delegados de Polícia do Estado de São Paulo), ano 17, n ${ }^{\circ} 22$, São Paulo, dezembro de 1996, p. 27.

502 Cf. MAURÍCIO ZANÓIDE DE MORAES, Esgrimando com o professor Sérgio Marcos de Moraes Pitombo: os inexistentes poderes investigatórios criminais do Ministério Público in Revista do Advogado, $\mathrm{n}^{\circ}$ 78, ano XXIV, setembro de 2004, p. 72.

${ }^{503}$ Cf. ORLANDO MIRANDA FERREIRA, Inquérito policial e o Ato Normativo 314 - PGJ/CPJ in Revista Brasileira de Ciências Criminais, $n^{\circ}$. 45, São Paulo, Revista dos Tribunais, outubro-dezembro de 2003, pp. 262-266.
} 
Constituição Federal, além de possuir outros vícios, como invasão a poderes e atribuições privativos do Poder Judiciário ${ }^{504}$.

Seja como for, após analisar a legislação infraconstitucional relacionada às investigações criminais e ao Ministério Público, é possível afirmar que o Código de Processo Penal, a Lei $n^{\circ}$ 8.625/93, a Lei Complementar no 75/93 e as Leis Complementares Estaduais de São Paulo e Rio de Janeiro, respectivamente a Lei Complementar no 734/93 e a Lei Complementar $n^{\circ}$ 106/03 (aqui mencionadas para exemplificar como a questão é tratada no âmbito dos Estados), em nenhum momento atribuem poderes investigatórios criminais ao Parquet de modo expresso, nem o regulamentam. Apenas os Atos Normativos editados pelo Ministério Público (Ato no 98/96 - CPJ, Ato Normativo 314-PGJ/CPJ e Resolução $n^{\circ} 13$ do Conselho Nacional do Ministério Público) conferem expressamente ao Ministério Público a função de investigar delitos e visam a, de algum modo, disciplinar a realização desta atividade.

Seja como for, fato é que o direito à investigação do Ministério Público deve ser reconhecido por decorrer do próprio direito à prova assegurado pela Constituição Federal de 1988, ainda que não expressamente.

E, diferentemente do que aduzem muitos juristas pátrios, a atribuição da função investigatória criminal ao Parquet não encontra qualquer óbice no texto constitucional, uma vez que a atividade de apurar o cometimento de infrações penais, sua autoria e demais circunstâncias inerentes ao ilícito não foi incumbida com exclusividade à polícia.

O fato, porém, de o direito à investigação não ter sido facultado expressamente ao Parquet (e às demais possíveis partes no processo penal, conforme se verá adiante), muito menos regulamentado, gera muitas dúvidas e questionamentos acerca de seu cabimento e do modo como tal direito deve ser exercido.

${ }^{504}$ Cf. CEZAR ROBERTO BITTENCOURT, A inconstitucionalidade da Resolução $n^{\circ} 13$ do Conselho Nacional do Ministério Público in Boletim do Instituto Brasileiro de Ciências Criminais, ano 14, $\mathrm{n}^{\circ} 170$, janeiro de 2007, p. 12. Sobre o assunto, acrescenta RENATO STANZIOLA VIEIRA que o Ministério Público, "da atribuição funcional de exercer o controle externo da atividade policial (art. 129, VII, CF), tenta tomar para si a atividade de polícia investigativa, sem a contrapartida da fiscalização judicial, apanágio do Estado Democrático de Direito. E, claro, assim não se controla a atividade policial" Cf. Procedimento investigatório criminal, esse outro desconhecido in Boletim do Instituto Brasileiro de Ciências Criminais, ano 14, nº 168, novembro de 2006, p. 13. 
O próprio Supremo Tribunal Federal, desde a década de 90, oscilava em reconhecer a constitucionalidade da instrução preliminar ministerial, proferindo decisões contrárias $^{505}$ e favoráveis ${ }^{506}$ nesse sentido.

Em tempos mais recentes, a referida Corte teve oportunidade de se pronunciar novamente sobre a questão, mas deixou de fazê-1o ${ }^{507}$. Foi apenas no início de 2009 que o Supremo Tribunal Federal proferiu decisão reconhecendo clara e expressamente a possibilidade de o Parquet promover investigações criminais. Mais precisamente em 10 de março daquele ano, ao julgar o Habeas Corpus n. 91.661, a Segunda Turma do STF reconheceu por unanimidade que o Ministério Público, como titular da ação penal pública, pode realizar investigações prévias ao oferecimento da denúncia, pois o inquérito policial seria uma peça meramente informativa, não sendo indispensável à formação da convicção do Parquet.

A teoria dos poderes implícitos também foi lembrada como fator a permitir a realização de investigações pelo Ministério Público, tendo sido ressalvado ainda o fato de que o reconhecimento da possibilidade de o Parquet promover atos de instrução preliminar não significa retirar da Polícia suas atribuições constitucionais.

Deve-se ressaltar, no entanto, que a decisão não foi esclarecedora, pois foi reconhecida a legitimidade das investigações criminais do Ministério Público em algumas hipóteses, as quais não foram especificadas ${ }^{508}$.

Depois deste julgado líder, muitos outros foram proferidos pela Segunda Turma do Supremo Tribunal Federal admitindo a realização de investigações penais pelo Parquet $^{509}$, mas, até o momento, o Pleno do tribunal não deliberou sobre o assunto. Esperase que quando do julgamento do $\mathrm{HC}^{\circ}$ 84.548, assim como da ADIN no 3.806 e da ADIN $\mathrm{n}^{\mathrm{o}}$ 3.836, o Plenário da mais alta Corte de nosso País se pronuncie em definitivo sobre o

${ }^{505}$ Cf. RE 205473/AL, Rel. Min. Carlos Velloso, Segunda Turma, j. 15/12/1998, RE 233072/RJ, Rel. Min. Néri da Silveira, Rel. p/ Acórdão Min. Nelson Jobim, Segunda Turma, j. 18/05/1999, RHC 81326/DF, Rel. Min. Nelson Jobim, Segunda Turma, j 06/05/2003.

${ }^{506}$ Cf. MS 21729/DF, Rel. Min. Néri da Silveira, Tribunal Pleno, j. 05/10/1995, HC 75769/MG, Rel. Min. Octavio Gallotti, Primeira Turma, j. 30/09/1997, HC 80948/ES, Rel. Min. Néri da Silveira, Segunda Turma, j. $07 / 08 / 2001$.

${ }_{507}$ Cf. HC 85172/SC, Rel. Min. Marco Aurélio, Primeira Turma, j 22/02/2005, RHC 84404/SP, Rel. Min. Carlos Britto, Primeira Turma, j. 29/03/2005.

${ }^{508}$ Cf. HC 91661-9/PE, Rel. Min. Ellen Gracie, Segunda Turma, j 10/03/2009.

${ }^{509}$ Cf. HC 89837/DF, Rel. Min. Celso de Mello, Segunda Turma, j 20/10/2009, HC 93930/RJ, Rel. Min. Gilmar Mendes, Segunda Turma, j. 07/12/2010, HC 97969/RS, Rel. Min. Ayres Britto, Segunda Turma, j. 01/02/2011. 
direito do Ministério Público de realizar atos de instrução na primeira fase da persecução penal.

Vale ainda ressaltar que também o Superior Tribunal de Justiça proferiu, ao longo do tempo, decisões contrárias e favoráveis às investigações ministeriais, as primeiras principalmente na década de $90^{510}$, e as últimas desde meados da década passada ${ }^{511}$. Esta última tendência apenas se intensificou depois de reconhecidos os poderes investigatórios criminais do Parquet pelo Supremo Tribunal Federal ${ }^{512}$, embora ainda tenham sido proferidas decisões onde foi professado entendimento contrário ${ }^{513}$.

Oportuno, no entanto, salientar que muitas das decisões acima referidas, embora reconheçam o direito à investigação do Ministério Público, salientam a necessidade de edição de uma lei para melhor disciplinar esta relevante prerrogativa do Parquet.

Lembra NEREU JOSÉ GIACOMOLLI que o grande problema do poder investigatório que se pode outorgar ao Ministério Público é a inexistência de um "iter procedimental" preestabelecido para tanto ${ }^{514}$.

Os atos normativos editados pela própria instituição tiveram a louvável intenção de conferir maior legitimidade e segurança jurídica às investigações ministeriais, porém, não se afiguram o veículo normativo adequado a disciplinar a matéria, dada a necessidade de uma regulamentação que, além de apresentar caráter geral e abstrato, afaste o risco de eventual seletividade das investigações criminais, e imponha fiscalização externa sobre esta atividade. GUILHERME DE SOUZA NUCCI é um dos autores que criticam a investigação ministerial por tais aspectos, e sustenta que nem mesmo uma lei ordinária poderia dispor sobre a matéria ${ }^{515}$.

Para ADA PELLEGRINI GRINOVER, somente uma lei complementar poderia instituir e regulamentar as investigações criminais do Ministério Público, por força

${ }^{510}$ Cf. RHC 4769/PR, Rel. Min. Luiz Vicente Cernicchiaro, Sexta Turma, j. 07/11/1995, RESP 76171/AL, Rel. Min. William Patterson, Sexta Turma, j. 13/02/1996.

511 Cf. ROMS 17884/SC, Rel. Min. Gilson Dipp, Quinta Turma, j. 17/11/2005, HC 55100/RJ, Rel. Min. Arnaldo Esteves Lima. Quinta Turma, j. 09/05/2006.

512 Cf. HC 94.129/RJ, Rel. Min. Laurita Vaz, Quinta Turma, j. 23/02/2010, HC 60976/ES, Rel. Min. Og Fernandes, Sexta Turma, j. 04/10/2011.

${ }^{513}$ Cf. HC 65292/GO, Rel. Min. Maria Thereza de Assis Moura, Sexta Turma, j.12/05/2009, HC 86.272/SP, Rel. Min. Maria Thereza de Assis Moura, Sexta Turma, j. 07 /12/2010.

${ }^{514} \mathrm{Cf}$. A fase preliminar do processo penal - Crises, misérias e novas metodologias investigatórias, Rio de Janeiro, Lumen Juris, 2011, p. 34.

${ }^{515}$ Cf. A investigação criminal e a atuação do Ministério Público in Revista CEJAP, volume 5, no 7, 2004, pp. 22-23. 
do disposto no art. 128, $\S 5^{\mathrm{o}}$ da Constituição Federal ${ }^{516}$, segundo o qual leis complementares da União e dos Estados devem estabelecer a organização, as atribuições e o estatuto de cada Ministério Público ${ }^{517}$.

Respeitado o posicionamento acima exposto, afigura-se mais adequado o entendimento segundo o qual a previsão do art. $128, \S 5^{\circ}$ da Constituição Federal não impede que leis ordinárias também estabeleçam ao Parquet funções diversas das que lhe foram conferidas no texto constitucional, bastando que aquelas sejam com este compatíveis.

Sobre o assunto, no julgamento da $\mathrm{ADI} \mathrm{n}^{\mathrm{o}} 2.794 / \mathrm{DF}^{518}$, o Pleno do Supremo Tribunal Federal decidiu que o art. 128, $\S 5^{\circ}$, da Constituição Federal não impôs reserva absoluta à lei complementar para conferir atribuições ao Ministério Público ou a cada um dos seus ramos, na União ou nos Estados-membros. No julgado, asseverou-se que o art. 129, IX, contém uma "norma de encerramento", e que, por não exigir explicitamente lei complementar, admite que leis ordinárias possam aditar novas funções às diretamente outorgadas ao Ministério Público pela Constituição, desde que compatíveis com as finalidades da instituição e às vedações de que nelas se incluam a representação judicial e a consultoria jurídica das entidades públicas. Lembrou o aresto que leis de cunho processual, ordinárias, conferem há muito tempo ao Parquet atribuições diversas das previstas expressamente no texto constitucional.

No mesmo sentido, HUGO NIGRO MAZZILLI já afirmou que, com base no art. $128, \S 5^{\circ}$ da Constituição Federal, é possível concluir que só as leis orgânicas de cada Ministério Público podem criar regras de organização e carreira, mas suas funções podem ser impostas por normas infraconstitucionais diversas daquelas, desde que compatíveis com a destinação da instituição, como acontece com o Código Civil, o Código de Defesa do Consumidor, o Estatuto da Criança e do Adolescente, entre outros ${ }^{519}$.

Ou seja, embora a lei complementar seja um veículo normativo adequado à regulamentação das funções do Parquet, não é o único. Leis ordinárias também podem impor ao Ministério Público atribuições diversas das constantes na Constituição e nas leis

\footnotetext{
${ }^{516}$ Eis o que estatui o referido dispositivo do texto constitucional: "Art. 128, $\S 5^{\circ}$. Leis complementares da União e dos Estados, cuja iniciativa é facultada aos respectivos Procuradores-Gerais, estabelecerão a organização, as atribuições e o estatuto de cada Ministério Público (...)”.

${ }^{517} \mathrm{Cf}$. Investigações pelo Ministério Público in Boletim do Instituto Brasileiro de Ciências Criminais, ano 12, $\mathrm{n}^{\mathrm{o}} 145$, dezembro de 2004, p. 04.

${ }^{518}$ Cf. STF, ADI no 2.794/DF, Rel. Min. Sepúlveda Pertence, Tribunal Pleno, j. 14.12.2016.

${ }^{519}$ Cf. Regime jurídico do Ministério Público, 6a ed., São Paulo, Saraiva, 2007, p. 353.
} 
complementares já existentes. E algumas funções nem precisam encontrar expressa previsão legal para serem exercidas pelos membros da instituição, por conta da aplicação da teoria dos poderes implícitos, acima referida.

Em outras palavras, o fato de nenhuma lei complementar ou ordinária prever e disciplinar expressamente a função investigatória criminal do Parquet não impede o exercício de tal atribuição, que decorre de outras previstas inclusive na Constituição Federal. Lembre-se, ademais, que a investigação criminal é um direito decorrente do próprio direito à prova.

Desse modo, o art. 128, $\S 5^{\circ}$ da Constituição Federal não obsta que, na ausência de lei complementar a referir-se expressamente à investigação criminal ministerial, o Parquet atue nessa seara de forma ampla e abrangente, sem observar regras ou parâmetros específicos, salvo os limites impostos por outras normas, inclusive constitucionais, no que com elas conflitar. Mas como justamente essa falta de disciplina legal torna tão questionáveis os atos de instrução preliminar do Parquet, faz-se premente a necessidade de regulamentação da matéria.

Muitos têm sugerido que a apuração de delitos pelo Ministério Público se dê em caráter excepcional ${ }^{520}$ ou subsidiário, de modo a viabilizar a elucidação de crimes que, de outra maneira, não seriam desvendados ${ }^{521}$, ou então nos casos em que a investigação policial é normalmente falha e omissa, a exemplo dos delitos cometidos pelos próprios agentes policiais $^{522}$.

A disciplina detalhada sobre a instrução preliminar ministerial afastaria o risco de indesejável seletividade dos casos a serem investigados pelo Parquet, permitiria que recursos materiais e humanos fossem disponibilizados para tal fim de maneira organizada e sistematizada, além do que permitiria que o exercício de tal função fosse fiscalizada, interna e externamente.

\footnotetext{
${ }^{520}$ Cf. MARIA THEREZA ROCHA DE ASSIS MOURA, Os sistemas de persecução penal e seus órgãos de acusação in Criminalia, $\mathrm{n}^{\circ}$ 2, vol. 69, 2003, p. 111, e HUGO NIGRO MAZZILLI, As investigações do Ministério Público para fins penais in Revista Magister de Direito Penal e Processual Penal, ano 1, $\mathrm{n}^{\circ}$ 5, 2005, p. 24.

${ }^{521}$ Nesse sentido, sustenta GERALDO PRADO que "a excepcionalidade dos casos de investigação criminal do Ministério Público, de lege ferenda, há de ser compreendida, do ponto de vista do direito, como emanação do critério da proporcionalidade. Nos limites do devido processo legal, sacrifica-se o ideal de afastamento do Ministério Público da investigação criminal, pelo qual é viabilizado o controle constitucional da atividade de polícia judiciária, para permitir a investigação de crimes que de outra maneira não seriam investigados". Cf. Sistema acusatório - A conformidade constitucional das leis processuais penais, $4^{\mathrm{a}}$ ed., Rio de janeiro, Lumen Juris, 2006, p. 133.

${ }_{522}$ Cf. LENIO LUIZ STRECK e LUCIANO FELDENS, Crime e Constituição - A legitimidade da função investigatória do Ministério Público, Rio de Janeiro, Forense, 2003, p. 111.
} 
Ademais, o regramento da matéria permitiria ainda aos cidadãos conhecer antecipadamente por quem seriam investigados e qual seria o procedimento aplicável à hipótese, o que só contribuiria para o afastamento da instabilidade e da insegurança jurídica dessa fase de instrução prévia ${ }^{523}$. Ou seja, a regulamentação por lei da atividade investigatória ministerial definiria seus limites, o relacionamento com as instituições policiais, e os modos pelos quais os direitos dos investigados seriam assegurados, tais como o direito à defesa técnica já nesta fase, o direito ao silêncio, o direito de acesso aos autos da investigação, entre outros ${ }^{524}$.

Em suma, embora a ausência de previsão e regulamentação legal das investigações ministeriais não impeça sua realização, constitui um fator de permanente instabilidade, pois enseja o constante questionamento acerca de sua legalidade. A existência de um procedimento específico para a realização desta atividade investigatória, previsto em lei, com contornos e limites de atuação bem definidos dos membros do Parquet, certamente permitiria que o direito à investigação da instituição fosse exercido de forma mais plena, além do que evitaria uma série de críticas e impugnações comumente suscitadas nos dias de hoje.

\subsection{INVESTIGAÇÃO CRIMINAL E DEFESA}

No que diz respeito ao exercício do direito à investigação pela defesa no ordenamento jurídico brasileiro, é possível afirmar que o mesmo encontra grande resistência, sendo praticamente inexistente sua verificação nos casos concretos.

Isto se deve em grande parte às previsões constitucionais e legais concernentes ao tema, as quais ensejam discussões até mesmo sobre a existência do direito de defesa na fase inicial da persecução penal.

Como visto anteriormente, o direito à prova, do qual decorre o direito à investigação, está intimamente ligado aos direitos de ação e de defesa, e em relação a este, previu o art. $5^{\circ}, \mathrm{LV}$, da Constituição Federal de 1988 que são assegurados o contraditório e ampla defesa, com os meios e recursos a ela inerentes, aos litigantes, em processo judicial ou administrativo, e aos acusados em geral.

${ }^{523}$ Cf. NEREU JOSÉ GIACOMOLLI, A fase preliminar do processo penal - Crises, misérias e novas metodologias investigatórias, Rio de Janeiro, Lumen Juris, 2011, P. 36.

${ }_{524}$ Cf. ANTONIO SCARANCE FERNANDES, Teoria geral do procedimento e o procedimento no processo penal, São Paulo, Revista dos Tribunais, 2005, p. 100. 
Uma vez que na fase de instrução preliminar não existe ainda processo judicial, nem processo administrativo propriamente dito, muitos autores sustentam inexistir contraditório e ampla defesa nesta etapa ${ }^{525}$, o que, no fim, inviabilizaria o exercício do direito à investigação.

Sobre a inexistência de processo judicial na etapa inicial da persecução penal parece não haver maiores dúvidas, uma vez que o processo tem início com o oferecimento da denúncia ou queixa-crime ${ }^{526}$.

No entanto, discute-se a existência de verdadeiro processo administrativo na fase de instrução prévia, ou de mero procedimento.

Neste ponto, imperiosa se faz a distinção entre as noções de processo e procedimento. AFRÂNIO SILVA JARDIM esclarece que "o processo é uma seqüência de atos, agrupados de forma orgânica e teleológica, utilizada pelo órgão jurisdicional para o julgamento da pretensão do autor ou de sua admissibilidade. Já o procedimento tem uma noção meramente formal, nada mais sendo do que a direção que os atos processuais tomam, ou seja, o rito a ser imprimido aos atos do processo. Em outras palavras, procedimento é uma coordenação sucessiva de atos que exteriorizam o processo. (...) Para finalizar, pode-se dizer que o processo cria uma relação entre pessoas (autor, juiz, réu), enquanto o procedimento é uma mera relação entre atos ${ }^{\text {,527. }}$.

No âmbito do Direito Administrativo, a jurista ODETE MEDAUAR não se afasta da distinção levada a efeito acima, ao afirmar que "procedimento distingue-se de processo porque, basicamente, significa a sucessão encadeada de atos. Processo, por seu lado, implica, além do vínculo entre atos, vínculos jurídicos entre os sujeitos, englobando direitos, deveres, poderes, faculdades, na relação processual ${ }^{, 528}$.

${ }^{525}$ FERNADO DE ALMEIDA PEDROSO, por exemplo, sustenta inexistir até mesmo direito de defesa na fase investigativa, pois o caráter inquisitivo desta deve ser preservado. Ou seja, para o autor, assegurar tal direito na instrução preliminar levaria à sua ineficácia e possível procrastinação, além do que o direito de defesa dirige-se ao juiz da causa depois de instaurado o processo, não à autoridade policial, e pela própria falta de possibilidade de defesa nesta etapa da persecução, qualquer irregularidade formal nela praticada não apresenta maiores consequências. Ressalva, no entanto, o jurista, o cabimento de habeas corpus contra flagrantes ilegalidades praticadas no inquérito, e a admissibilidade de o advogado comunicar-se com o indiciado e compulsar os autos da investigação. Cf. Processo penal - o direito de defesa: repercussão, amplitude e limites, $3^{\text {a }}$ ed., São Paulo, Revista dos Tribunais, 2001, pp. 58-62.

${ }^{526}$ Cf. JULIO FABBRINI MIRABETE, Processo penal, $17^{\mathrm{a}}$ ed., São Paulo, Atlas, 2005, p. 135.

527 Cf. Direito processual penal, $9^{\mathrm{a}}$ ed., Rio de Janeiro, Forense, 2000, p. 27. Ressalva, no entanto, ANTONIO SCARANCE FERNANDES que o procedimento consiste num "conjunto de atos marcado por seqüencia predeterminada e pela vinculação de todos a um mesmo objetivo final”. Cf. Teoria geral do procedimento e o procedimento no processo penal, São Paulo, Revista dos Tribunais, 2005, p. 15.

${ }^{528}$ Cf. Direito administrativo moderno, $9^{\mathrm{a}}$ ed., São Paulo, Revista dos Tribunais, 2005, p. 189. 
Considerando, pois, as distinções efetuadas, forçoso concluir que a investigação criminal não constitui verdadeiro processo administrativo, mas sim mero procedimento, pois não passa de uma "coordenação de atos que se sucedem",529.

Entende-se, porém, que mesmo não sendo a instrução preliminar um verdadeiro processo administrativo, onde a garantia do contraditório deve ser observada, em tal fase é assegurado ao menos o direito de defesa aos suspeitos/investigados. Isto porque embora não haja acusação formal, consubstanciada em denúncia ou queixa-crime, na fase de investigação são praticados diversos atos que podem ser considerados acusatórios em sentido amplo, e no mais das vezes implicam restrição a direitos e garantias fundamentais.

Ao interpretar o artigo $5^{\circ}, \mathrm{LV}$, da Constituição Federal, afirma NEREU JOSÉ GIACOMOLLI que as garantias do contraditório e da ampla defesa estão inseridas no devido processo legal, que abrange o processo judicial ou administrativo, o procedimento administrativo, e os meros procedimentos. Segundo o jurista, "a expressão “acusados em geral” não se limita ao acusado em processo judicial, após o recebimento de uma acusação, mas, por ser genérica e globalizante, abarca o suspeito, sempre que assim seja considerado por quem investiga, desde a formalização de seu início" ${ }^{\text {,530, }}$

Em obra dedicada especificamente ao tema do exercício do direito de defesa no inquérito policial, MARTA SAAD também sustentou que, na etapa preliminar da persecução penal já existe acusação em sentido largo, assim entendida como atribuição de ato ou fato criminoso a autor/partícipe, devendo por isso mesmo ser garantido ao investigado o direito de defesa no sentido de resistência, oposição de forças, o que abrangeria o direito de rebater as imputações feitas, o direito à assistência por advogado, $\mathrm{o}$ direito ao silêncio, e o direito de ver produzidas as provas por ele requeridas ${ }^{531}$.

Note-se que, embora o contraditório esteja intimamente relacionado ao direito de defesa, não há contradição lógica em afirmar que apenas o último pode ser exercido durante a instrução preliminar.

${ }^{529}$ Cf. ANTONIO CARLOS DE ARAÚJO CINTRA, ADA PELLEGRINI GRINOVER E CÂNDIDO RANGEL DINAMARCO, Teoria geral do processo, 20ª ed., São Paulo, Malheiros, 2004, p. 277.

${ }^{530} \mathrm{Cf}$. A fase preliminar do processo penal - Crises, misérias e novas metodologias investigatórias, Rio de Janeiro, Lumen Juris, 2011, pp. 88-89.

${ }^{531}$ Cf. O direito de defesa no inquérito policial, São Paulo, Revista dos Tribunais, 2004, pp. 222-223. Acrescenta a jurista que se pode falar em acusação lato sensu em diversos atos praticados no inquérito policial, entre os quais a prisão em flagrante, a nota de culpa, boletim de ocorrência de autoria conhecida, requerimento/requisição/portaria de instauração do inquérito policial, e medidas de natureza cautelar determinadas nesta etapa. 
Como já observado alhures ${ }^{532}$, nem é desejável um contraditório amplo e irrestrito na fase pré-processual da persecutio criminis, pois isso frustraria muitas diligências investigatórias que dependem do sigilo para seu êxito, além do que tornaria desnecessário o próprio processo. No entanto, o direito de defesa deve ser assegurado nesta etapa, sob pena de restarem violados diversos direitos fundamentais do investigado.

O jurista JOAQUIM CANUTO MENDES DE ALMEIDA há tempos já sustentava a necessidade de o direito de defesa ser assegurado na fase de instrução preliminar pois, nas palavras do autor, "seria absolutamente contrário a qualquer senso de justiça, e ao sistema mesmo de nosso processo penal, afastá-lo [da investigação], como se nada tivesse ele a ver com sua própria liberdade ${ }^{, 533}$.

Também JOSÉ BARCELOS DE SOUZA, na década de 80, entendia que embora não fosse obrigatória a participação da defesa na fase investigativa, já que a instrução nela feita era provisória, no mais das vezes o investigado tinha interesse em demonstrar a ausência dos requisitos para a prisão cautelar, ou a presença de causas de exclusão do crime, ou mesmo esclarecer certas circunstâncias relativas às provas irrepetíveis, o que levou o autor a sustentar a possibilidade de a defesa atuar já nesta etapa da persecução penal, inclusive com assistência de advogado, requerimento de diligências, formulação de quesitos, apresentação de documentos, e acesso aos autos do inquérito por intermédio de seu defensor ${ }^{534}$.

O referido jurista concluíra, ainda sob a égide da Constituição anterior, que "se, de um lado, não se aplica ao inquérito o contraditório exigido pela Constituição, não é lícito, por outro lado, impedir a plenitude da defesa, garantida pela mesma Constituição" ${ }^{, 535}$. A assertiva se manteve plenamente aplicável com o advento da Constituição Federal de 1988.

Pois bem, reconhecida a existência do direito de defesa na fase de instrução preliminar, possível também o reconhecimento do direito à prova e, por conseguinte, do direito à investigação, também nesta etapa, até para fins de preservação de outros princípios e garantias, como o da igualdade entre acusação e defesa.

\footnotetext{
${ }^{532}$ Veja-se mais sobre o assunto no item 2.5.

${ }^{533}$ Cf. Principios fundamentais do processo penal, São Paulo, Revista dos Tribunais, 1973, p. 217.

${ }^{534} \mathrm{Cf}$. Estas e outras prerrogativas do investigado foram objeto de minuciosa análise pelo autor na obra $A$ defesa na polícia e em juizo: teoria e prática do processo penal, $5^{\text {a }}$ ed., São Paulo, Saraiva, 1980, pp. 19-34.

${ }_{535}$ Cf. A defesa na polícia e em juízo: teoria e prática do processo penal, $5^{\text {a }}$ ed., São Paulo, Saraiva, 1980, p. 28.
} 
No entanto, tal conclusão parece colidir com a previsão do art. 14 do Código de Processo Penal ${ }^{536}$, segundo a qual o investigado poderia apenas requerer a realização de determinadas diligências na fase investigativa, as quais poderiam ser realizadas ou não, a critério da autoridade policial.

Como já visto ${ }^{537}$, há quem interprete literalmente o aludido dispositivo, restringindo a atuação probatória da defesa na instrução preliminar ao mero requerimento de diligências que podem nem ser realizadas pelo órgão policial, se este assim reputar conveniente ${ }^{538}$.

Colhem-se também opiniões na doutrina de que como o Código de Processo Penal, em seu artigo 14, alude ao "indiciado" sem ter disciplinado a figura do indiciamento, o simples investigado não pode nem requerer a realização de diligências enquanto não for indiciado, sendo que o indiciamento também é realizado a juízo da autoridade policial $^{539}$.

Mas há quem interprete o dispositivo sem tanto rigor, de modo que, se relevante a diligência requerida pela defesa e indeferida pela autoridade policial, seria possível, mesmo em face do disposto no art. 14 do CPP, dirigir o pedido ao Ministério Público ou ao Judiciário, que determinariam a realização da medida, se o caso ${ }^{540}$, ou então insistir no pedido administrativo, dirigindo-o ao superior hierárquico do delegado de polícia $^{541}$.

Existem também muitas vozes dissonantes em nossa doutrina, segundo as quais a autoridade policial não poderia deixar de realizar os atos investigatórios requeridos

\footnotetext{
536 Eis o exato teor do referido dispositivo legal: "O ofendido, ou seu representante legal, e o indiciado poderão requerer qualquer diligência, que será realizada, ou não, a juízo da autoridade”.

${ }^{537} \mathrm{O}$ item 2.2 tratou deste assunto.

${ }^{538}$ Cf. JULIO FABBRINI MIRABETE, Código de processo penal interpretado, $11^{\mathrm{a}}$ ed., São Paulo, Atlas, 2006, pp. 118-119.

${ }^{539}$ Cf. ANTONIO SCARANCE FERNANDES, Teoria geral do procedimento e o procedimento no processo penal, São Paulo, Revista dos Tribunais, 2005, p. 99.

${ }^{540}$ Cf. GUILHERME DE SOUZA NUCCI, Código de processo penal comentado, 9a ed., São Paulo, Revista dos Tribunais, 2009, p. 115.

${ }^{541}$ Cf. LUIZ CARLOS BETANHO, Código de processo penal e sua interpretação jurisprudencial, coord. Alberto Silva Franco e Rui Stoco, vol. 2, 2a ed., São Paulo, Revista dos Tribunais, 2004, p. 106. Sobre o assunto, FERNANDO DA COSTA TOURINHO FILHO entende que a única diligência requerida pela defesa que a autoridade policial não poderia se recusar a efetuar seria o exame de corpo de delito. Mas, de lege ferenda, sugere o autor que se confira ao indiciado, e mesmo ao ofendido, o direito de requerer diligências que considerem indispensáveis e que, em caso de indeferimento veiculado em despacho fundamentado, deveria ser cabível recurso ao superior hierárquico ou reclamação ao juiz. Cf. Código de processo penal comentado, 13ª ed., São Paulo, Saraiva, 2010, p. 102.
} 
pelo investigado, em observância tanto ao seu direito de defesa ${ }^{542}$ como ao princípio da igualdade, já que as diligências requeridas pelo Ministério Público devem, forçosamente, ser realizadas pela polícia, nos termos do art. 13, II, do Código de Processo Penal.

Como ressaltado anteriormente, JOAQUIM CANUTO MENDES DE ALMEIDA já afirmava que a expressão "a juízo da autoridade" constante do art. 14 do CPP relaciona-se ao poder-dever inquisitivo do delegado de polícia na condução de seu mister, não representando restrição ao direito de defesa ${ }^{543}$.

Sobre o assunto, assevera MARTA SAAD que "releitura do disposto no art. 14 do CPP, em face da garantia constitucional da ampla defesa, permite concluir que o delegado de polícia somente poderá negar a realização do pedido se este for inviável, sob o ponto de vista fático, ou inócuo. Não pode a autoridade policial negar o requerimento de diligência formulado pelo acusado, desde que guarde importância e correlação com o esclarecimento dos fatos e a defesa do acusado. Em face do disposto no art. $5^{\circ}$, LV da Constituição da República, o requerimento de diligências pelo indiciado é um direito subjetivo seu, que não pode ser negado arbitrariamente pela autoridade, e na eventualidade de ser indeferido o pedido, o acusado pode fazer uso do mandado de segurança, vez que ferido direito líquido e certo, ou, até mesmo para alguns, valer-se do habeas corpus ${ }^{, 544}$.

Logo, o investigado/suspeito da prática de um crime tem direito a ver realizados os atos investigatórios requeridos à autoridade policial, desde que não sejam flagrantemente irrelevantes ou impertinentes, mas sua atuação probatória não pode se resumir a esta prerrogativa, sob pena de violação ao seu direito à investigação, assegurado pela Constituição Federal de 1988.

A fim de que o direito à investigação do possível réu em futura ação penal seja integralmente efetivado, necessário se faz permitir-lhe também a realização de seus próprios atos instrutórios, com vistas à descoberta de elementos de informação que podem levar até mesmo a não propositura da ação penal, ou mesmo servir como fonte de prova num processo vindouro.

${ }^{542}$ Cf. ANDRÉ AUGUSTO MENDES MACHADO, Investigação criminal defensiva, São Paulo, Revista dos Tribunais, 2010, p.117.

${ }_{543}$ Cf. Principios Fundamentais do Processo Penal, São Paulo, Revista dos Tribunais, 1973, p. 213.

${ }^{544}$ Cf. O Direito de Defesa no Inquérito Policial, São Paulo, Revista dos Tribunais, 2004, pp. 351-352. 
Esta conclusão, todavia, não encontra largo respaldo na doutrina, muito menos na jurisprudência pátria. Mesmo autores que se dedicaram exclusivamente ao tema da investigação criminal defensiva, como ANDRÉ AUGUSTO MENDES MACHADO, sustentam a impossibilidade de o investigado proceder à sua própria investigação em face do ordenamento jurídico posto. Segundo o referido autor, "para retirar toda a carga de preconceito sobre a investigação defensiva e lhe atribuir o mesmo peso da investigação pública, deve haver previsão legal de procedimento para a sua realização, no qual se defina, com base em critérios constitucionais e legais, a forma de execução e documentação dos atos investigatórios pelo defensor, punindo o seu exercício irregular ou abusivo" ${ }^{545}$.

Mesmo a jurista MARTA SAAD, defensora da ampla garantia do direito de defesa na fase do inquérito policial, tampouco reconheceu expressamente ao investigado a prerrogativa de realizar sua própria investigação. No entanto, após tecer considerações sobre legislações estrangeiras que permitem ao argüido realizar atos instrutórios já na fase extrajudicial da persecução penal, constatou a autora que se evolui para a tendência mais moderna no sentido de permitir ao investigado uma participação ampla na instrução $\operatorname{preliminar}^{546}$, o que, por certo, inclui a realização de investigações particulares.

Sobre o assunto, imperiosa é a menção ao posicionamento de ANTONIO SCARANCE FERNANDES, para quem, embora não haja previsão sobre a possibilidade de o investigado obter elementos de prova para sua defesa, não está ele impedido de investigar $^{547}$.

Também para FRANCISCO DA COSTA OLIVEIRA existe um princípio da livre investigação dos fatos (decorrente de outros direitos como o direito à liberdade individual, o direito de se informar e de ser informado livremente, o direito à livre circulação, entre outros), e que permitiria ao imputado realizar sua própria instrução preliminar. Ou seja, para o jurista português, assim como as pessoas têm liberdade para investigar o paradeiro de alguém desaparecido, o comportamento de seu cônjuge, os bens

\footnotetext{
${ }^{545}$ Cf. Investigação criminal defensiva, São Paulo, Revista dos Tribunais, 2010, p. 179.

${ }^{546}$ Cf. O direito de defesa no inquérito policial, São Paulo, Revista dos Tribunais, 2004, pp. 352-353.

${ }^{547}$ Cf. Processo penal constitucional, $6^{\mathrm{a}}$ ed., São Paulo, Revista dos Tribunais, 2010, p. 241. No mesmo sentido se posicionam ANDRÉ BOIANI E AZEVEDO e ÉDSON LUÍS BALDAN, A preservação do devido processo legal pela investigação defensiva (ou do direito de defender-se provando) in Boletim do Instituto Brasileiro de Ciências Criminais, n⿳ำ 137, abril de 2004, pp. 06-08.
} 
do devedor, entre outros, também teriam liberdade para investigar fatos e circunstâncias relativas a um delito ${ }^{548}$.

Este é o entendimento que se revela, de fato, mais acertado, e consentâneo com as premissas estabelecidas no início deste trabalho, segundo as quais o direito à investigação é um corolário do próprio à prova, e por isso deve ser assegurado ao longo de toda a persecução penal, e a todas as possíveis partes de um futuro processo, tanto para o fim de evitar sua propositura equivocada e descabida, como para permitir que os titulares de aludido direito possam traçar suas respectivas estratégias de atuação, e conheçam desde logo as fontes de prova que servirão para a produção dos meios de prova na fase processual.

Ressalva, no entanto, ANTONIO SCARANCE FERNANDES que, embora não haja óbices legais à investigação defensiva, os elementos de informação por ela colhidos são vistos com desconfiança pelos juízes e promotores, quando não são simplesmente desconsiderados, além do que o defensor não pode se valer da colaboração da polícia $^{549}$.

A propósito, o fato de o defensor não possuir poderes coercitivos para compelir terceiros a fornecer informações e documentos dificulta o exercício da atividade investigativa, praticamente obstando-a quando quem detém aqueles se nega a colaborar ${ }^{550}$.

Seja como for, diante do reconhecimento de que o Ministério Público pode exercer seu direito à investigação independentemente da existência de regramento legal a disciplinar tal atividade ${ }^{551}$, imperioso se faz o reconhecimento de tal prerrogativa também à defesa, sob pena de não só obstar o direito à investigação que lhe foi conferido pela

\footnotetext{
548 Prossegue o autor, afirmando que haveria, contudo, um risco específico em tal atividade de investigação particular, qual seja "o risco de serem interpretadas como diligências de alguém que tenta, não investigar, mas encobrir o crime, ou eliminar elou subverter a genuidade das provas do crime; no fundo, obstruir a realização da Justiça Penal”. Cf. Processo penal constitucional, $6^{\mathrm{a}}$ ed., São Paulo, Revista dos Tribunais, 2010, p. 241. Também defendem a realização de investigações particulares ANDRÉ BOIANI AZEVEDO e ÉDSON LUÍS BALDAN. Cf. A preservação do devido processo legal pela investigação defensiva (ou do direito de defender-se provando) in Boletim do Instituto Brasileiro de Ciências Criminais, n⿳ ${ }^{-137}$, abril de 2004, pp. 06-08.

${ }^{549}$ Cf. Teoria geral do procedimento e o procedimento no processo penal, São Paulo, Revista dos Tribunais, 2005, p. 99.

${ }^{550}$ Cf. ANDRÉ AUGUSTO MENDES MACHADO, Investigação criminal defensiva, São Paulo, Revista dos Tribunais, 2010, p. 176.

${ }^{551}$ Sobre o assunto, veja-se o item 4.2.
} 
Constituição Federal, mas também de violar a igualdade processual e a paridade de $\operatorname{armas}^{552}$ entre as possíveis partes de eventual processo penal.

Muito se fala que permitir apenas ao Parquet a realização de atos de investigação gera patente desequilíbrio na etapa pré-processual da persecutio criminis $^{553}$. Dessa forma, facultar à defesa a realização de sua própria investigação criminal consistiria numa medida salutar ao almejado equilíbrio entre aqueles que figurarão como partes em eventual processo ${ }^{554}$, além de consistir numa medida extremamente eficaz ao exercício do direito de defesa pelo imputado na fase investigatória de nossa persecução penal. Sobre o assunto, já asseverou PAOLO TONINI que "a noção de "direito de defesa" compreende não só o direito de defesa contra uma acusação judiciária mas também o direito de investigar e de produzir as provas que demonstrem os fatos alegados pela parte ${ }^{, 555}$.

Por ser também uma expressão do direito de defesa, a investigação criminal por esta realizada não objetiva necessariamente alcançar a verdade, ou toda ela, até porque é direcionada à colheita de informações favoráveis ao imputado ${ }^{556}$.

Aliás, a possibilidade de a defesa promover suas próprias investigações representa, mais do que uma vertente do direito à defesa, um dos desdobramentos do próprio direito à prova, que deve ser reconhecido antes e mesmo fora do processo ${ }^{557}$.

\footnotetext{
${ }^{552}$ Como bem observa ADA PELLEGRINI GRINOVER, "entende-se, modernamente, por par condicio ou igualdade de armas, o princípio de equilíbrio de situações, não iguais mas recíprocas, como o são, no processo penal, as dos oficios da acusação e da defesa”. Cf. O processo constitucional em marcha, São Paulo, Max Limonad, 1985, p. 13.

${ }^{553}$ Nesse sentido são as opiniões de CEZAR ROBERTO BITTENCOURT, $A$ inconstitucionalidade dos poderes investigatórios do Ministério Público in Revista Brasileira de Ciências Criminais, $\mathrm{n}^{\circ}$ 66, São Paulo, Revista dos Tribunais, maio-junho de 2007, p. 251, LUIZ FLÁVIO BORGES D’URSO, Constituição Federal versus poder investigatório do MP in Revista CEJAP, vol. 6, nº 8, 2005, p. 03, RODRIGO TADEU PIMENTA DE OLIVEIRA, A investigação direta pelo Ministério Público e o sistema acusatório in Revista de Direito Militar, $\mathrm{n}^{0}$ 75, janeiro-fevereiro de 2009, p. 31, e CARLOS EDUARDO CABRAL BELOTI, $O$ Ministério Público e a investigação criminal direta in Revista IOB de Direito Penal e Processual Penal, ano 10, no 56, junho-julho de 2009, p. 124.

${ }^{554}$ Cf. MARCOS ALEXANDER COELHO ZILLI, Os bons ventos de Haia in Boletim do Instituto Brasileiro de Ciências Criminais, nº 190, setembro de 2008, p. 14.

${ }^{555}$ Cf. Direito de defesa e prova cientifica: novas tendências do processo penal italiano in Revista Brasileira de Ciências Criminais, ano 12, nº 48, maio-junho de 2004, p. 195.

556 Sobre o assunto, asseverou FRANCISCO DA COSTA OLIVEIRA que "sem a necessidade ou a preocupação de contribuir para a descoberta de "toda a verdade", é certo, mas com o fito de proporcionar a descoberta dos factos e das circunstâncias favoráveis aos interesses do argüido, consoante o sentido lógico e processual da sua Defesa, o defensor não deve confiar o destino do argüido "à sorte" das investigações oficiosas e, antes pelo contrário, deverá nas mesmas procurar intervir". Cf. A defesa e a investigação do crime, $2^{\mathrm{a}}$ ed. Coimbra, Almedina, 2008, pp. 18-19. E o fato de a investigação defensiva ser também uma manifestação do direito de defesa levou também ANDRÉ AUGUSTO MENDES MACHADO a concluir que "o defensor não está adstrito a apresentar à Autoridade Judiciária os elementos obtidos em sua atividade investigatória, nem mesmo a denunciar crime do qual tenha conhecimento no exercício dessa função”. Cf. Investigação criminal defensiva, São Paulo, Revista dos Tribunais, 2010, p. 176.
} 
Nesse sentido, muito pertinentes são as observações de ANTONIO MAGALHÃES GOMES FILHO, para quem o direito à investigação é condição indispensável ao exercício do direito à prova, de modo que não seria possível negar ao investigado e seu defensor as atividades de pesquisa probatória prévia "com vistas à obtenção do material destinado à demonstração das teses defensivas " ${ }^{\text {"58 }}$.

Desse modo, sói concluir que, mesmo em face da ausência de norma legal expressa a autorizar a investigação defensiva, esta pode ser realizada, pelos argumentos até aqui exaustivamente expostos.

O reconhecimento do direito à investigação também à defesa, porém, não significa sua efetivação na realidade brasileira. Para que tal direito seja assegurado plena e concretamente aos acusados em geral, necessária se faz sua regulamentação legal.

Como visto anteriormente ${ }^{559}$, na Itália nem mesmo a existência de previsão legal relativa à investigação defensiva permitiu sua implementação. Foi só a partir do momento em que tal prática foi detalhadamente regulamentada que os atos de instrução preliminar realizados por particulares passaram a ser amplamente realizados e levados em consideração pelas autoridades italianas.

No Brasil, a falta de reconhecimento expresso do direito à investigação já dificulta seu exercício, e mesmo quando este se verifica, as diligências realizadas por particulares costumam ser mal vistas, quando não simplesmente ignoradas.

Nessa perspectiva, a regulamentação da investigação defensiva, com o detalhamento do procedimento para sua realização e documentação, lhe conferiria maior legitimidade, lhe asseguraria idêntico peso ao da investigação estatal, ao menos em tese, evitaria eventuais abusos por parte dos advogados ${ }^{560}$, fixaria os limites dessa atividade, definiria os modos através dos quais essa instrução preliminar particular poderia ser auxiliada pelos órgãos estatais, entre outras tantas vantagens passíveis de enumeração.

A disciplina legal da investigação defensiva deve, no entanto, levar em consideração todas as críticas que costumam ser tecidas a seu respeito, em especial as de

\footnotetext{
${ }^{557}$ Para PAOLO TONINI, a expressão "direito à prova" compreende o direito de todas as partes de buscar fontes de prova, requerer a admissão de um determinado meio de prova, participar de sua produção e apresentar uma valoração no momento das conclusões. Cf. A prova no processo penal italiano, trad. Alexandra Martins e Daniela Mróz, São Paulo, Revista dos Tribunais, 2002, p. 83.

${ }^{558}$ Cf. Direito à Prova no Processo Penal, São Paulo, Revista dos Tribunais, 1997, pp. 86-87.

${ }^{559}$ Item 3.2.3.1.

${ }^{560}$ Cf. ANDRÉ AUGUSTO MENDES MACHADO, Investigação criminal defensiva, São Paulo, Revista dos Tribunais, 2010, p. 179.
} 
que tal espécie de instrução preliminar gera dúvidas acerca da veracidade das informações obtidas, dada a premente parcialidade com que é desenvolvida ${ }^{561}$, bem como de que sua prática acentua a desigualdade entre os imputados ricos e pobres ${ }^{562}$.

Sobre este último ponto, sugere-se que o Estado custeie a realização de tal atividade àqueles que não apresentem condições de arcar com os gastos para contratação de advogados ou investigadores particulares ${ }^{563}$. A Defensoria Pública, nesse sentido, poderia assumir mais esta função ${ }^{564}$, recebendo recursos materiais e humanos para a realização deste mister, já que é a instituição constitucionalmente incumbida de defender, em todos os graus, os interesses dos necessitados ${ }^{565}$.

Há também quem chame a atenção para o risco de criação de agências e escritórios de investigação particulares que, em sua atuação, poderiam misturar atividades de investigação com espionagem, contrainteligência e corrupção, com a indesejável atuação de investigadores privados ${ }^{566}$. $\mathrm{Na}$ verdade, em relação a este último aspecto, não há maiores óbices à atuação de detetives privados nas investigações particulares, bastaria que o exercício desta profissão fosse também devidamente disciplinado, e fiscalizado, como se verifica atualmente na Itália.

Já em Portugal, como a atividade dos detetives particulares no âmbito criminal não encontra regulamentação legal, é feita no mais das vezes sem qualquer controle ou preparação. Diante deste quadro, o jurista lusitano FRANCISCO DA COSTA OLIVEIRA considera mais sensato que o próprio investigado e seu defensor realizem a investigação $^{567}$. A recomendação é válida e aplicável também ao ordenamento jurídico brasileiro, que tampouco normatizou a matéria em questão.

\footnotetext{
${ }^{561}$ Cf. ANTONIO MAGAlHÃes GOMES FILHO, Direito à Prova no Processo Penal, São Paulo, Revista dos Tribunais, 1997, p. 87.

562 Cf. ANTONIO SCARANCE FERNANDES, Reação defensiva à imputação, São Paulo, Revista dos Tribunais, 2002, p. 119.

${ }^{563}$ Cf. ANDRÉ AUGUSTO MENDES MACHADO, Investigação criminal defensiva, São Paulo, Revista dos Tribunais, 2010, p. 181.

${ }^{564}$ Neste sentido é também a opinião de LUIZ RASCOVSKI. Cf. Investigação criminal defensiva: uma luz no fim do túnel com sua previsão no novo Código de Processo Penal (Projeto de Lei 156/09) in Boletim do Instituto Brasileiro de Ciências Criminais, nº 219, fevereiro de 2011, p. 14-15.

${ }^{565}$ O jurista NEREU JOSÉ GIACOMOLLI rebate, porém, este argumento, alegando que a falta de implementação integral das Defensorias Públicas impediria que os investigados em situações econômicas precárias tivessem assegurado o mesmo direito facilmente exercitável pelos suspeitos mais abastados. Cf. $A$ fase preliminar do processo penal - Crises, misérias e novas metodologias investigatórias, Rio de Janeiro, Lumen Juris, 2011, pp. 48-49.

${ }^{566}$ Cf. NEREU JOSÉ GIACOMOLLI, A fase preliminar do processo penal - Crises, misérias e novas metodologias investigatórias, Rio de Janeiro, Lumen Juris, 2011, p. 49.

${ }^{567} \mathrm{Cf}$. A defesa e a investigação do crime, $2^{\mathrm{a}}$ ed. Coimbra, Almedina, 2008, pp. 36-37.
} 


\subsection{INVESTIGAÇÃO CRIMINAL E VÍTIMA}

De início, cumpre salientar que, nos últimos tempos, a vítima tem assumido importância cada vez maior não só no processo penal brasileiro, mas também em outros ordenamentos jurídicos ${ }^{568}$. Durante muito tempo, a vítima permaneceu praticamente alijada do processo penal: a instituição da persecução penal pública, que substituiu o regime da vingança privada, acabou por retirar todas suas faculdades e desprezar, no mais das vezes, sua vontade ${ }^{569}$. Com o passar do tempo, porém, percebeu-se que a participação da vítima no procedimento criminal é essencial à resolução dos conflitos com verdadeira pacificação social.

Sobre o assunto, muito pertinentes são as observações de JULIO B. J. MAIER, para quem a vítima é protagonista principal do conflito social instaurado com a prática do ilícito penal, ao lado do autor do crime, de modo que o litígio nunca terá solução integral se o interesse daquela não for atendido, ou ao menos, se não lhe for concedida a oportunidade de influir na persecução penal. Segundo o autor, "só com a participação dos protagonistas - o imputado e o ofendido como hipotéticos protagonistas principais resulta racional buscar a solução do conflito otimamente, isto é, da melhor maneira possivel $^{, 570 .}$

Ou seja, após um longo período de vedação à efetiva participação da vítima na persecução penal, esta e seus interesses passaram recentemente a ser alvo de preocupação mais intensa dos juristas e dos sistemas processuais penais, o que se deve tanto à busca por meios alternativos, consensuais e mais informais de solução de controvérsias, diante da crise de legitimidade de que padece atualmente a Justiça penal ${ }^{571}$,

${ }^{568}$ Cf. JACOBO LÓPEZ BARJA DE QUIROGA, Tratado de derecho procesal penal, Navarra, Aranzadi, 2004, p. 790, e ANTONIO SCARANCE FERNANDES, O papel da vítima no processo criminal, São Paulo, Malheiros, 1995, p. 11.

${ }^{569}$ Cf. ALBERTO BOVINO, La participación de la víctima en el procedimiento penal in Revista Brasileira de Ciências Criminais, nº 21, São Paulo, Revista dos Tribunais, janeiro-março de 1998, p. 419.

${ }^{570}$ Eis o referido trecho no idioma original: "Sólo con la participación de los protagonistas - el imputado y el ofendido como hipotéticos protagonistas principales - resulta racional buscar la solución del conflicto óptimamnete, esto es, de la mejor manera posible”. Cf. Derecho procesal penal, Tomo II, Parte General Sujetos procesales, Buenos Aires, Editores del Puerto, 2003, p. 611.

${ }^{571}$ Cf. ALBERTO BOVINO, La participación de la víctima en el procedimiento penal in Revista Brasileira de Ciências Criminais, no 21, São Paulo, Revista dos Tribunais, janeiro-março de 1998, p. 422. 
como à necessidade de combater a burocracia estatal, e de exercer certo controle externo sobre a atividade do Ministério Público e da polícia ${ }^{572}$.

Aliás, em relação àquele primeiro aspecto, muito se tem discutido a implementação de modelos diferenciados de Justiça criminal, baseados na idéia de consenso, e onde um dos principais focos é a reparação dos danos causados à vítima. A chamada Justiça Restaurativa é um excelente exemplo, neste sentido ${ }^{573}$.

No Brasil, este movimento em prol da adoção de soluções consensuais de conflitos penais inspirou a previsão, pela Constituição Federal de 1988, dos Juizados Especiais Criminais (artigo 98, I, e $\S 1^{\circ}$, da Carta). A fim de dar cumprimento à norma constitucional, foram editadas a Lei dos Juizados Especiais Criminais estaduais (Lei $\mathrm{n}^{\mathrm{o}}$ 9.099/95) e a Lei dos Juizados Especiais federais (Lei $\mathrm{n}^{0}$ 10.259/01). Nas palavras de alguns dos elaboradores do Anteprojeto que resultou no primeiro dos referidos diplomas, "cuida-se de lei sumamente relevante, porque pretende testar um novo modelo ("novo paradigma”) de Justiça Criminal, fundado no consenso ",574.

Tanto o atendimento dos interesses da vítima é importante no âmbito dos Juizados Especiais que uma das medidas despenalizadoras previstas foi a composição civil dos danos. Se a vítima e o autor do fato anuem acerca da forma de reparação dos prejuízos causados àquela, o respectivo acordo é homologado pelo juízo e acarreta a renúncia ao direito de queixa ou representação, respectivamente, para os crimes de ação penal privada ou pública condicionada, nos termos do art. 74, parágrafo único, da Lei $n^{\circ}$ 9.099/95, aplicável subsidiariamente à Lei no 10.259/01.

Este e outros avanços obtidos em benefício dos interesses da vítima no ordenamento pátrio não se verificam, porém, em matéria probatória e, mais especificamente, no que concerne ao direito à investigação.

$\mathrm{Na}$ verdade, no processo penal brasileiro praticamente não se cogita do direito à investigação da vítima. No plano constitucional, ao ofendido foi assegurado, basicamente, o direito de promover a ação privada subsidiária da pública, quando esta não

${ }^{572}$ Cf. JULIO B. J. MAIER, Derecho procesal penal, Tomo II, Parte General - Sujetos procesales, Buenos Aires, Editores del Puerto, 2003, p. 612.

${ }^{573}$ Sobre o assunto, recomenda-se a obra de HOWARD ZEHR, Trocando as lentes - um novo foco sobre o crime e a Justiça, São Paulo, Palas Athena, 2008.

${ }_{574}$ Participaram do grupo de trabalho que apresentou o aludido Anteprojeto ADA PELLEGRINI GRINOVER, ANTONIO MAGALHÃES GOMES FILHO e ANTONIO SCARANCE FERNANDES, que, ao lado de LUIZ FLÁVIO GOMES, exararam o comentário transcrito em Juizados especiais criminais: Comentários à Lei 9.099, de 26.09.1995, 5ª ed., São Paulo, Revista dos Tribunais, 2005, p. 48. 
for intentada no prazo legal (art. 5 , LIX, da Constituição Federal em vigor) e o direito à reparação dos danos causados pelo delito (art. $5^{\circ}, \mathrm{XLV}$, do mesmo diploma) ${ }^{575}$. O direito à investigação da vítima não foi nem remotamente aventado.

Como visto ${ }^{576}$, apenas em tempos recentes a doutrina pátria passou a admitir o direito à investigação do próprio imputado, e, substancialmente, como forma de assegurar a paridade de armas entre as possíveis partes em futuro processo penal, diante das nítidas e irremediáveis investidas do Ministério Público na instrução preliminar. O direito à investigação da vítima, quer como querelante, quer como assistente de acusação, é quase nulo, inexistente em nosso sistema.

Aliás, cabe neste ponto salientar que o direito à investigação do ofendido se faz presente tanto nas hipóteses em que ele ocuparia, em futuro processo, a condição de parte principal (nos crimes de ação penal privada exclusiva, subsidiária da pública ou personalíssima ${ }^{577}$ ) como nas hipóteses em que ele ocuparia a posição de assistente de acusação (nos crimes de ação penal pública, condicionada ou não ${ }^{578}$ ), com todas as diferenças daí decorrentes.

Pois bem, não obstante o direito à investigação da vítima não encontre guarida atualmente no processo penal brasileiro, imperioso é o seu reconhecimento. Não se pode olvidar que a vítima atua como responsável pela acusação nos crimes de ação penal privada, sendo inegável sua qualidade de parte principal nestes processos. Além disso, mesmo quando atua como assistente de acusação, a vítima assume a condição de parte, ainda que coadjuvante, auxiliar, colaboradora do Ministério Público ${ }^{579}$. Em ambos os casos, tem a vítima interesse em comprovar fatos relevantes aos interesses por ela

575 Para FLAVIANE DE MAGALHÃES BARROS, a Constituição Federal de 1988 também assegurou à vítima o direito à participação no procedimento sumaríssimo dos Juizados Especiais Criminais, e o direito ao contraditório e à ampla defesa, pois a todos os afetados por uma decisão judicial é dado o direito de nela influir. Cf. Direito das vítimas e sua participação no processo penal: a análise do PLS 156/2009 a partir de uma interpretação constitucional in $\mathrm{O}$ novo processo penal à luz da Constituição (Análise crítica do Projeto de Lei ${ }^{\circ}$ 156/2009, do Senado Federal), Rio de Janeiro, Lumen Juris, 2010, p. 322.

${ }^{576}$ Item 4.3.

${ }^{577}$ A ação penal é de iniciativa exclusivamente privada nas hipóteses em que apenas se procede mediante queixa do ofendido ou de seu representante legal, é privada subsidiária da ação penal de iniciativa pública quando o representante do Ministério Público deixa de oferecer a denúncia no prazo legal, e o ofendido oferece a queixa em seu lugar, e é privada personalíssima quando o direito de queixa é personalíssimo e intransferível, ou seja, não há possibilidade de representação legal ou voluntária, nem de sucessão do querelante em caso de morte ou ausência, como sói acontecer nos crimes de ação penal exclusivamente privada. Atualmente, o único exemplo de ação penal privada personalíssima é a do crime de induzimento a erro essencial e ocultação de impedimento (art. 236 do Código Penal). Cf. GUSTAVO HENRIQUE RIGHI IVAHY BADARÓ, Direito processual penal, Tomo I, Rio de Janeiro, Elsevier, 2008, pp. 77-79.

${ }^{578}$ Cf. JULIO FABBRINI MIRABETE, Processo penal, $17^{\mathrm{a}}$ ed., São Paulo, Atlas, 2005, p. 376.

${ }^{579}$ Cf. GUSTAVO HENRIQUE RIGHI IVAHY BADARÓ, Direito processual penal, Tomo I, Rio de Janeiro, Elsevier, 2008, p. 158. 
perseguidos. Vale lembrar, neste ponto, da amplitude do objeto da prova, o qual não se resume à autoria e à materialidade do delito. Como visto anteriormente ${ }^{580}$, podem ser objeto de prova todos os fatos pertinentes e úteis à verificação das alegações formuladas pelas partes acerca das demais circunstâncias que envolvem o crime ${ }^{581}$.

Considerando o acima exposto, e o fato de que a vítima assume, desde a fase inicial da persecução penal, a condição de possível parte em futuro processo, quer como autora, quer como assistente da acusação, imperioso se torna o reconhecimento de seu direito à investigação, até como decorrência do direito à prova que lhe é assegurado na fase judicial da persecutio criminis.

Ademais, proibir a vítima de exercer suas próprias investigações violaria o princípio da igualdade ${ }^{582}$, pois a outras possíveis partes em eventual processo penal é assegurado o direito à investigação, conforme visto anteriormente ${ }^{583}$.

Reconhecido, pois, o direito à investigação da vítima em nosso ordenamento jurídico, resta apenas verificar como o mesmo pode ser exercido em face dos dispositivos legais vigentes aplicáveis à matéria. Aliás, o tratamento conferido à tal parte pelo nosso Código de Processo Penal carece de sistematização, e mesmo de rigor terminológico. Ora se fala em lesado, ora se fala em ofendido, e por vezes se fala simplesmente em vítima.

Segundo ANTONIO SCARANCE FERNANDES, do disposto em nosso diploma processual penal, é possível concluir, grosso modo, que vítima seria o sujeito passivo da infração penal, lesado seria aquele que sofreu prejuízo em decorrência do crime, e ofendido seria a vítima em sentido processual ${ }^{584}$. Diante desta classificação empreendida, vítima e ofendido serão utilizados como sinônimos neste trabalho.

É válido ainda mencionar que no sistema processual penal italiano, também se distinguem as figuras do ofendido e do lesado. O primeiro seria o titular do interesse, do bem jurídico protegido pela norma incriminadora ${ }^{585}$, ao passo que o último seria aquele

\footnotetext{
${ }^{580}$ Item 1.3.4.

${ }^{581}$ Cf. GIUSTINO GATTI, Codice di procedura penale annotato com la giurisprudenza, 18 ${ }^{\mathrm{a}}$ ed., Napoli, Grupo Editoriale Esselibri Simone, 2010, p. 493.

${ }^{582}$ Cf. PASQUALE VENTURA, Le indagine difensive, Milano, Giuffrè, 2005, p. 27.

${ }^{583}$ Vejam-se, a respeito, os itens 4.2. e 4.3.

${ }^{584}$ Cf. La víctima en el proceso penal - su régimen legal en Argentina, Bolívia, Brasil, Chile, Paraguay, Uruguay, Ediciones de Palma, Buenos Aires, 1997, pp. 122-123.

${ }^{585}$ Cf. PAOLO TONINI, Manuale breve - Diritto processuale penale, Milano, Giuffrè, 2009, p. 99.
} 
que sofreu um dano, patrimonial ou não, em decorrência do crime e que tem direito à reparação do prejuízo ${ }^{586}$.

Pois bem, de acordo com o ordenamento jurídico vigente em nosso País, em matéria de investigação criminal, uma das primeiras medidas asseguradas à vítima é o requerimento da instauração de inquérito policial. A notícia da ocorrência de um crime pela vítima ou por qualquer do povo é chamada de "delação", e pode ser simples, quando há mera comunicação do delito, ou postulatória, quando se pede a instauração de inquérito policial $^{587}$.

Nos termos do art. $5^{\circ}, \S \S 4^{\circ}$ e $5^{\circ}$ do Código de Processo Penal, nos crimes de ação penal pública condicionada, o inquérito policial não pode ser iniciado sem a representação da vítima, e nos crimes de ação penal privada, a instauração do inquérito depende de requerimento da vítima.

Se a autoridade policial indeferir ou não apreciar o pedido da vítima nas hipóteses acima referidas, cabe recurso ao chefe de Polícia, segundo dispõe o art. $5^{\circ}, \S 2^{\circ}$ do CPP, e se tal impugnação não obtiver êxito, o ofendido pode formular seu pedido ao Ministério Público ou à autoridade judicial, que, se o caso, requisitarão a instauração do inquérito ao delegado de polícia, o qual, desta vez, não poderá deixar de dar início à investigação sobre o delito ${ }^{588}$.

Lembre-se ainda que, nos crimes de ação penal pública incondicionada, a vítima, ou qualquer outra pessoa, pode provocar a iniciativa do Ministério Público, fornecendo-lhe, por escrito, informações sobre o fato e a autoria e indicando o tempo, o lugar e os elementos de convicção acerca do crime, segundo o disposto no art. 27 do diploma processual penal em vigor. $\mathrm{Na}$ verdade, o dispositivo fala apenas em ação penal pública, mas entende-se que a ação referida é a incondicionada porque, quando se trata de

\footnotetext{
${ }^{586}$ Para MARIO PISANI, ALFREDO MOLARI, VINCENZO PERCHINUNNO e PIERMARIA CORSO, o lesado, ou seja, a pessoa que sofreu dano em virtude do crime, não tem qualquer participação na fase de instrução preliminar, uma vez que a pretensão civil de reparação do dano só pode ser exercida durante o processo. A intervenção do lesado durante as investigações só seria admissível se o mesmo também tivesse sido ofendido pelo delito cometido. Cf. Manuale di procedura penale, Bologna, Monduzzi, 1994, p. 360.

${ }^{587}$ Cf. JOSÉ FREDERICO MARQUES, Elementos de direito processual penal, vol. I, $2^{\mathrm{a}}$ ed., Campinas, Millenium, 2000, p. 148.

588 Cf. ANTONIO SCARANCE FERNANDES, O papel da vítima no processo criminal, São Paulo, Malheiros, 1995, p. 74. Observa ainda o jurista que, ao invés de recorrer ao chefe de Polícia em caso de recusa indevida de instauração do inquérito policial, o ofendido pode dirigir-se imediatamente ao Ministério Público ou ao Poder Judiciário para efetuar seu pedido.
} 
ação penal pública condicionada, a iniciativa do Ministério Público depende de provocação do ofendido (ou de seu representante legal) ou do Ministro da Justiça ${ }^{589}$.

Ainda no âmbito da instrução preliminar, o art. 14 do Código de Processo Penal pátrio faculta ao ofendido, ou a seu representante legal, assim como ao indiciado, requerer a realização de determinadas diligências na fase investigativa, as quais serão efetuadas ou não, a critério da autoridade policial.

Aqui, aplicam-se as mesmas conclusões obtidas quando da análise do dispositivo em relação ao direito à investigação da defesa ${ }^{590}$. Ou seja, embora haja quem interprete ao pé da letra o art. 14 do CPP, limitando a atuação probatória da vítima na instrução preliminar ao mero requerimento de diligências, as quais podem nem ser realizadas pela polícia ${ }^{591}$, é possível também concluir, em face do mesmo dispositivo, que a autoridade policial só poderá deixar de realizar as diligências requeridas pelo ofendido se estas forem infundadas.

Sobre o assunto, muito pertinentes são as observações de ANTONIO SCARANCE FERNANDES, para quem o melhor é " $a$ autoridade policial realizar a diligência, quando não se revelar inteiramente destituída de fundamento, porque importa muito a colaboração do ofendido. Via de regra, tem ele condições de fornecer dados $e$ informes relevantes para o esclarecimento do fato criminoso. Assim, só devem ser indeferidos seus requerimentos quando forem realmente desnecessários ou, no caso, implicarem inadequado atraso ou desvio na investigação ${ }^{, 592}$.

Logo, sempre que a autoridade policial negar indevidamente a realização de diligência requerida pelo ofendido ou seu representante legal, poderão estes formular o mesmo pedido ao superior hierárquico do delegado de polícia ${ }^{593}$, ou ao promotor ou ao juiz que acompanham o caso, que requisitarão a realização da providência, se não for indevida, tornando-a obrigatória à autoridade policial $^{594}$. As conclusões derivam até da aplicação,

\footnotetext{
${ }^{589}$ Cf. DAMÁSIO E. DE JESUS, Código de Processo Penal Anotado, São Paulo, Saraiva, 2000, p. 26.

${ }^{590}$ Item 4.3.

${ }^{591}$ Cf. JULIO FABBRINI MIRABETE, Código de processo penal interpretado, $11^{\mathrm{a}}$ ed., São Paulo, Atlas, 2006 , p. 118.

${ }^{592}$ Cf. La víctima en el proceso penal - su régimen legal en Argentina, Bolívia, Brasil, Chile, Paraguay, Uruguay, Ediciones de Palma, Buenos Aires, 1997, pp. 125-126.

${ }^{593}$ Cf. LUIZ CARLOS BETANHO, Código de processo penal e sua interpretação jurisprudencial, coord. Alberto Silva Franco e Rui Stoco, vol. 2, 2a ed., São Paulo, Revista dos Tribunais, 2004, p. 106.

${ }^{594}$ Cf. GUILHERME DE SOUZA NUCCI, Código de processo penal comentado, 9a ed., São Paulo, Revista dos Tribunais, 2009, p. 115, e FERNANDO DA COSTA TOURINHO FILHO, Código de processo penal comentado, $13^{\text {a }}$ ed., São Paulo, Saraiva, 2010, p. 102.
} 
por analogia, do disposto no art. $5^{\circ}, \S 2^{\circ}$, do CPP, e de seus consectários lógicos acima expostos.

Mas, para que o direito à investigação da vítima seja integralmente assegurado, necessário se faz permitir-lhe também a realização de seus próprios atos instrutórios, com vistas à descoberta de elementos de informação que podem levar à propositura da ação penal privada, ou da pública (quando o ofendido atua na condição de auxiliar do Ministério Público), e mesmo para fins de tutela dos interesses civis do ofendido.

Normalmente, a participação da vítima na fase de instrução preliminar é refutada pelo risco de que a persecução penal torne-se mera vingança privada ${ }^{595}$, e pelo temor de que o ofendido, ainda fortemente influenciado pelos acontecimentos, não apresente o distanciamento necessário para a realização de diligências que poderão ser usadas em desfavor do imputado.

Todavia, o receio de que a vítima seja movida unicamente por interesses particulares e, por isso, acabe prejudicando a realização dos atos de instrução prévia, não pode servir como óbice ao exercício de seu direito à investigação. O ofendido também tem interesse em demonstrar a veracidade de suas alegações, quer relativas à autoria e à materialidade do delito para fins de oferecimento de queixa-crime ou auxílio às investigações oficiais, quer referentes ao resguardo de suas pretensões civis.

Sobre o primeiro ponto, aliás, cumpre ressaltar que a participação da vítima pode ser essencial à elucidação do crime e de sua autoria, através de seu depoimento, do reconhecimento pessoal ou da coisa subtraída e encontrada em poder do suspeito, da submissão a exame de corpo de delito ou perícia grafotécnica, sem contar que tal material probatório normalmente é dotado de alto poder de convencimento ${ }^{596}$.

Além dessa colaboração direta da vítima, a ela deve ser facultada também a realização de outros atos investigatórios no intuito de esclarecer os aspectos essenciais do delito e proteger seus interesses civis. Quanto a este último aspecto, deve ser permitido ao ofendido realizar diligências tanto para busca e posterior apreensão da coisa subtraída, de forma a assegurar sua rápida restituição, como para seqüestro de bens, com vistas a

${ }^{595}$ Cf. JULIO B. J. MAIER, Derecho procesal penal, Tomo II, Parte General - Sujetos procesales, Buenos Aires, Editores del Puerto, 2003, p. 606.

${ }_{596}$ Cf. ANTONIO SCARANCE FERNANDES, La víctima en el proceso penal - su régimen legal en Argentina, Bolivia, Brasil, Chile, Paraguay, Uruguay, Ediciones de Palma, Buenos Aires, 1997, p. 126. 
garantir a futura reparação do dano, e mesmo para compelir o suspeito a ressarcir os prejuízos causados antes da propositura da ação penal ${ }^{597}$.

É bem verdade que, atualmente, a vítima pode requerer à autoridade policial, ou mesmo ao Poder Judiciário, a realização de providências que resguardem seus interesses civis. No entanto, melhor seria se o ofendido também pudesse, através de investigação própria, diligenciar a busca da coisa que lhe foi subtraída, ou mesmo a de bens outros, com o objetivo de assegurar a reparação dos danos causados em futuro processo de execução.

Mas não se pode deixar de ressalvar que, mesmo nas hipóteses em que o delito cometido enseja a propositura de ação penal privada, a doutrina pátria costuma questionar o direito da vítima de empreender suas próprias investigações. Tal se deve, principalmente, ao fato de nosso ordenamento não fazer qualquer referência a esta possibilidade. Há quem sustente, com base no referido silêncio da lei, que o inquérito policial é pressuposto praticamente indispensável ao oferecimento de queixa-crime ${ }^{598}$.

Parecem, no entanto, mais acertadas as conclusões já obtidas quando do exame do direito à investigação do Ministério Público e da defesa ${ }^{599}$, no sentido de que a ausência de previsão legal acerca de tal prerrogativa não impede seu exercício, mesmo porque o direito à investigação decorre do direito à prova, e deve ser garantido a todas as possíveis partes de um futuro processo, seja para evitar seu errôneo ajuizamento, seja para permitir a busca de fontes de prova que poderão ser utilizadas na fase judicial da persecução penal, seja para propiciar a definição das melhores estratégias de atuação dos titulares de tal direito.

Não se pode negar, é claro, que os elementos de informação obtidos pela vítima através de sua investigação própria possivelmente não gozarão, perante a autoridade judicial, da mesma credibilidade atribuída aos informes policiais ou ministeriais, estes oficiais, além do que o ofendido, assim como o imputado, não goza de poderes coercitivos

597 Cf. ANTONIO SCARANCE FERNANDES, La víctima en el proceso penal - su régimen legal en Argentina, Bolivia, Brasil, Chile, Paraguay, Uruguay, Ediciones de Palma, Buenos Aires, 1997, p. 127. Como exemplo desta última hipótese, o autor traz o crime de emissão de cheque sem fundos, em que, como o pagamento do título antes da denúncia elide o crime, o "credor requer o inquérito para ameaçar o emitente com possível acusação e, assim, levá-lo a pagar o valor do cheque e evitar a ação penal".

${ }^{598}$ REJANE ALVES DE ARRUDA é uma das juristas que defende tal posicionamento, ao afirmar que "o silêncio do legislador não é casual: se, por um lado, não exclui a possibilidade da queixa-crime não ser oferecida com base em IP, por outro, não admite a total viabilidade de tal direcionamento". Cf. A importância do inquérito policial nos crimes de ação penal privada in Revista Síntese de Direito Penal e Processual Penal, no 15, São Paulo, Síntese, agosto-setembro de 2002, p. 22.

${ }^{599}$ Itens 4.2. e 4.3. 
para a realização de suas diligências, o que prejudica sua efetividade, principalmente quando terceiros se negam a colaborar.

Daí porque, embora o direito à investigação da vítima deva ser reconhecido desde logo, necessária se faz a regulamentação normativa de tal atividade, a fim de que sua legalidade não seja questionada, de que os advogados e outros profissionais por ventura incumbidos dessa função possam agir com segurança, sabedores dos limites de sua atuação e das condutas consideradas abusivas no exercício de tal mister, e também para que os elementos de informação colhidos possam ser efetivamente levados em consideração por quem de direito, assim como o são os resultantes das investigações estatais.

Os inconvenientes das investigações particulares já apontados quando do estudo do direito à investigação da defesa ${ }^{600}$, entre os quais o risco de apresentação de elementos de informação falsos, de manipulação e alteração de dados, e de acentuação das diferenças entre litigantes ricos e pobres, igualmente devem ser levados em conta pelo legislador brasileiro ao tratar do assunto.

A propósito, sugere-se, neste ponto, que a mesma disciplina prevista para as investigações defensivas seja aplicável às investigações da vítima, tal como ocorre no ordenamento jurídico italiano. Lá, as investigações privadas podem ser realizadas não só pelo advogado do imputado ${ }^{601}$, mas também pelo defensor do ofendido e/ou lesado pelo crime $^{602}$, aplicando-se idêntico procedimento em ambos os casos.

E, como bem recorda PALO TONINI ao tratar do assunto, o ofendido pode participar da fase inicial da persecução penal tanto realizando suas próprias investigações (através de seu advogado, de um substituto, de um assistente técnico ou de um investigador privado autorizado), como assistindo aos poucos atos de investigação nos quais é admitida sua presença (basicamente, os atos instrutórios irrepetíveis) ${ }^{603}$.

\footnotetext{
${ }^{600}$ Sobre o assunto, ver item 4.3.

${ }^{601}$ É válido mencionar que, no processo penal italiano, distinguem-se as figuras do imputado ("imputato") e do indagado ("indagato"). Segundo PAOLO TONINI, a diferenciação se dá para fins eminentemente garantistas, de modo que "indagato" seria, basicamente, a pessoa investigada, a pessoa submetida às investigações criminais; já o termo "imputato" teria um significado preciso, qual seja o de pessoa à qual é atribuído o crime ao cabo das investigações. Cf. Manuale breve - Diritto processuale penale, Milano, Giuffrè, 2009, p. 81. Seja como for, a ambos é assegurado o direito à investigação no processo penal italiano. ${ }^{602}$ Cf. PASQUALE VENTURA, Le indagine difensive, Milano, Giuffrè, 2005, p. 25. É válido ainda mencionar que, na Itália, também podem realizar as chamadas "indagini difensive” os advogados da parte civil, do responsável civil e do civilmente obrigado pela pena pecuniária, figuras estas que, por não encontrarem previsão em nosso ordenamento, não serão aqui analisadas.

${ }^{603}$ Cf. Manuale breve - Diritto processuale penale, Milano, Giuffrè, 2009, p. 101.
} 
Por fim, faz-se necessário analisar a delicada questão do exercício do direito à investigação da vítima nos crimes de ação penal pública, condicionada ou não. Se já era questionável tal prerrogativa do ofendido nos crimes de ação penal privada, com maior dose de razão o é nos delitos cuja iniciativa para o oferecimento da denúncia é do Ministério Público. É que, embora em tais crimes a vítima possa figurar como parte eventual, seu ingresso na persecução penal como assistente de acusação só pode ocorrer depois de proposta a ação penal, nos termos do art. 268 do Código de Processo Penal vigente, e até o trânsito em julgado da condenação, conforme o art. 269 do mesmo texto legal $^{604}$.

O referido art. 268 do CPP estatui que "em todos os termos da ação pública, poderá intervir, como assistente do Ministério Público, o ofendido ou seu representante legal, ou, na falta, qualquer das pessoas mencionadas no art. 31”, que seriam o cônjuge, ascendente, descendente ou irmão da vítima.

Em face da aludida previsão legal, a doutrina brasileira é praticamente unânime acerca da impossibilidade de a vítima atuar como assistente de acusação já na fase extrajudicial da persecução penal. O jurista JULIO FABBRINI MIRABETE, por exemplo, sustenta que "referindo-se a lei a "processo" e, diante da figura do assistente, que é um auxiliar do Ministério Público, é evidente que não pode ser admitido durante o inquérito policial ou antes de instaurada a ação penal ${ }^{\text {,605. }}$.

Como principal justificativa para a vedação à participação do ofendido na instrução preliminar, costuma-se apontar a ausência de interesse da vítima em tal etapa da

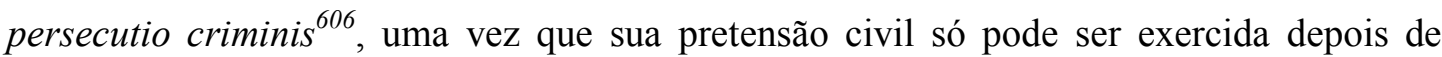
instaurado o processo.

No entanto, como visto alhures ${ }^{607}$, a natureza do interesse do assistente de acusação não é meramente patrimonial, porque tal conclusão implicaria reconhecer que a vítima só poderia atuar no intuito de conseguir o título executivo necessário à satisfação de sua pretensão no âmbito civil, o que não é verdade. Afinal, o assistente pode, por exemplo, recorrer da condenação imposta meramente para aumentar a pena, bem como atuar em processo onde houve crime apenas tentado, ou delito que não resultou em prejuízo

\footnotetext{
${ }^{604}$ Dispõe o art. 269 do CCP pátrio que "o assistente será admitido enquanto não passar em julgado a sentença e receberá a causa no estado em que se encontrar".

${ }^{605}$ Cf. Código de processo penal interpretado, $11^{\mathrm{a}}$ ed., São Paulo, Atlas, 2006, p. 692.

${ }^{606}$ Cf. GUILHERME DE SOUZA NUCCI, Código de processo penal comentado, 9a ed., São Paulo, Revista dos Tribunais, 2009, p. 568.

${ }^{607}$ Ver item 1.3.4.
} 
material, tudo isto porque tem interesse não apenas econômico na persecutio criminis, visa também a auxiliar o Parquet no exercício da tese de acusação amplamente considerada, segundo já decidiu o Supremo Tribunal Federal ${ }^{608}$. Resume FÁTIMA ZIYADE que "o assistente intervém não visando apenas ao interesse econômico mas também à correta aplicação da sanção penal ao infrator do dispositivo legal, atuando no interesse do Estado, e, via de conseqüência, na consecução de propósito de caráter público "609.

Aliás, embora a jurisprudência também seja praticamente pacífica acerca da proibição da habilitação da vítima como assistente de acusação durante a instrução preliminar $^{610}$, já houve nítidas demonstrações dos tribunais pátrios de que tal entendimento deve ser alterado ${ }^{611}$, baseadas justamente no fato de que o ofendido tem interesse também na apuração do ilícito penal e na adequada punição do responsável. Em Acórdão relativamente recente proferido pelo C. Superior Tribunal de Justiça, decidiu-se que, embora inadmissível a intervenção do assistente de acusação na fase extrajudicial da persecutio criminis, consoante o disposto no art. 268 do CPP, "não se pode privar a vítima, que efetivamente sofreu, como sujeito passivo do crime, o gravame causado pelo ato típico e antijurídico, de qualquer tutela jurisdicional, sob pena de ofensa às garantias constitucionais do acesso à justiça e do duplo grau de jurisdição" ${ }^{\text {,612. }}$.

Discussão semelhante se instalou no ordenamento jurídico italiano acerca da possibilidade de o defensor do responsável civil e da pessoa civilmente obrigada pela pena pecuniária realizar investigações na etapa extrajudicial da persecução penal. Tais figuras não encontram correspondência com qualquer outra existente no processo penal brasileiro, mas o fato é que, à semelhança do que ocorre com nosso assistente de acusação, só podem intervir na persecução penal depois de ajuizada a ação penal.

Pois bem, também no sistema processual penal italiano há quem sustente que o responsável civil e a pessoa civilmente obrigada pela pena pecuniária estão legitimados a desenvolver suas próprias investigações mesmo antes de assumirem a

\footnotetext{
${ }^{608}$ Sobre o assunto, vejam-se os julgados referidos no item 1.3.4.

${ }^{609}$ Cf. $O$ assistente da acusação, Porto Alegre, Livraria do Advogado, 1993, pp. 29-30.

${ }^{610}$ Cf. STF, Inquérito 381/DF, Rel. Min. Celio Borja, Tribunal Pleno, j. 21/09/1988, TJSP, Procedimento Investigatório do MP (peças de Informação) n 990.08.135792-5, Rel. Des. Ribeiro dos Santos, $15^{\text {a }}$ Câmara de Direito Criminal, j. 25.02.2010.

611 Como exemplo dessa corrente, a jurista FÁTIMA ZIYADE mencionou o seguinte julgado: TJSP, Apelação Cível 141.210, Rel. Des. Rezende Junqueira, 2a Câmara Criminal, j. 16/11/1981. Cf. O assistente da acusação, Porto Alegre, Livraria do Advogado, 1993, p. 82.

${ }^{612}$ Cf. STJ, HC 123365/SP, Rel. Min. Og Fernandes, Sexta turma, j. 22/06/2010.
} 
qualidade de partes pois, sem esta possibilidade, seu direito à prova ou à contraprova no processo restaria comprometido ${ }^{613}$.

Logo, mesmo em face da aparente vedação imposta pelo art. 268 do nosso Código de Processo Penal ao ingresso da vítima como assistente de acusação na etapa extrajudicial da persecução penal, parece ser possível o reconhecimento do direito à investigação do ofendido também nesta fase, por força de uma interpretação sistemática dos dispositivos constitucionais e legais relativos ao direito à prova, e à figura da vítima, a qual não deve receber determinado tratamento quando for parte principal, e outro completamente diferente quando for parte coadjuvante/eventual. Como bem observa FÁBIO RAMAZZINI BECHARA, não há motivo plausível para tal distinção, salvo o fato de que, quando atua como assistente, o ofendido apenas complementa a atividade do Ministério Público, ao passo que, quando atua como titular da ação penal, sua atuação é mais abrangente ${ }^{614}$.

Esta circunstância, aliás, é a única justificativa razoável para limitar a atuação probatória da vítima na qualidade de assistente de acusação, e durante toda a persecução, afinal, o imputado estará em situação desigual, pois terá contra si dois opositores, o Ministério Público e a vítima.

Sobre o assunto, muito pertinentes são as observações de JULIO B. J. MAIER, para quem "o único argumento racional para não tolerar a intromissão da vítima no procedimento se vincula à posição do imputado, debilitado pela incorporação de um novo acusador, quando não de vários, em casos específicos ",615.

O problema da existência de vários de acusadores em virtude da admissibilidade da vítima como auxiliar do Parquet apresenta duas soluções possíveis, segundo o jurista argentino, a primeira delas simplesmente impedir a intervenção da vítima no procedimento, o que não é desejável, pelas razões já expostas, ou então estabelecer alguns remédios jurídicos para equilibrar a situação das partes, por exemplo, o

${ }^{613}$ Cf. PASQUALE VENTURA, Le indagine difensive, Milano, Giuffrè, 2005, p. 26.

${ }^{614} \mathrm{Cf}$. Da assistência no processo penal in Boletim do Instituto Brasileiro de Ciências Criminais, ano 10, $\mathrm{n}^{\circ}$ 117, agosto de 2002, pp. 11-12.

${ }^{615}$ Eis o trecho, em vernáculo: "el único argumento racional para no tolerar la intromisión de la víctima en el procedimiento se vincula a la posición en él del imputado, debilitado por la incorporación de un nuevo acusador, cuando no de varios, en casos específicos". Cf. Derecho procesal penal, Tomo II, Parte General Sujetos procesales, Buenos Aires, Editores del Puerto, 2003, p. 608. 
fornecimento de assistência jurídica de qualidade e oficial ao imputado, assim como à vítima $^{616}$.

Diante de todas as considerações acima tecidas, relativas ao direito à prova de que é titular também o ofendido, à regra contida no CPP que permite o ingresso do assistente da acusação na persecução penal apenas depois de instaurado o processo, e à possibilidade de violação à paridade de armas que a existência de dupla investigação pelos opositores do imputado pode causar, afigura-se recomendável que o direito à investigação da vítima nos crimes de ação penal pública seja reconhecido com certas restrições. Tal entendimento é reforçado pelo fato de que, como assistente da acusação, o ofendido meramente auxilia o Ministério Público na tese acusatória, não é seu protagonista, além do que atua de acordo com seus interesses, que não são meramente patrimoniais, vale salientar ${ }^{617}$.

Sugere-se, assim, a adoção de regramento semelhante ao existente no ordenamento jurídico português acerca dos poderes instrutórios da vítima na qualidade de assistente de acusação. Lá, como já visto ${ }^{618}$, tal figura intervém na instrução preliminar na condição de colaborador subordinado ao Ministério Público, o que lhe permite apresentar memoriais ou requerimento de diligências probatórias ao Parquet, as quais são realizadas sempre que relevantes à demonstração dos fatos alegados ${ }^{619}$.

Todavia, mais do que postular pela realização de certos atos instrutórios, como sói acontecer no processo penal português, talvez fosse recomendável permitir à vítima, na qualidade de assistente de acusação, realizar investigação própria para a comprovação de alegações relativas a seus interesses civis, ou mesmo diligências complementares/subsidiárias às do Parquet para a apuração da autoria, materialidade do delito, e demais circunstâncias relevantes pendentes de esclarecimento. Tudo isto, é claro, dependeria de específica previsão legal, inexistente nos diplomas hoje vigentes em nosso País.

\footnotetext{
${ }^{616}$ Cf. Derecho procesal penal, Tomo II, Parte General - Sujetos procesales, Buenos Aires, Editores del Puerto, 2003, pp. 608-609.

${ }^{617}$ Posição semelhante é defendida por CHRISTIANO FRAGOSO, para quem os interesses da vítima, além de fundamentarem sua atuação, servem como limite aos poderes por ela exercitáveis. Cf. Assistente: a condição de vítima como limite à sua atividade in Boletim do Instituto Brasileiro de Ciências Criminais, ano $10, \mathrm{n}^{\mathrm{o}} 117$, agosto de 2002, pp. 03-05.

${ }^{618}$ Item 1.3.4.

${ }^{619}$ Cf. JORGE DE FIGUEIREDO DIAS, Direito processual penal, Coimbra, Coimbra Editora, 2004, p. 522.
} 


\section{CAPÍTULO V - DIREITO À INVESTIGAÇÃO NO MAIS RECENTE PROJETO DE NOVO CÓDIGO DE PROCESSO PENAL}

O Código de Processo Penal vigente em nosso País é de 1941. Foi elaborado sob a égide de um regime político autoritário, e por isso muitas de suas disposições são reflexo do momento atravessado pelo País à época. Vigorava o Estado Novo de Getúlio Vargas, e o Congresso Nacional encontrava-se fechado quando foi editado, por Decreto-lei, o Código de Processo Penal que até hoje vige ${ }^{620}$, claramente inspirado no diploma processual penal italiano de 1930, igualmente autoritário e capitaneado por Vincenzo Manzini, líder fascista daquele país.

É acentuado o viés repressivo e limitador das liberdades públicas do nosso Código de Processo Penal, tanto que da leitura de sua Exposição de Motivos depreende-se que o objetivo central do diploma era conferir maior eficiência e energia à ação repressiva do Estado contra os criminosos, em detrimento dos direitos e garantias fundamentais dos acusados, tratados os últimos, aliás, como sinônimos de favores ${ }^{621}$.

São marcantes ainda na legislação processual penal em vigor regras típicas de um sistema inquisitório ${ }^{622}$, a exemplo de algumas relacionadas à matéria probatória ${ }^{623}$. Muitas delas não têm sido mais aplicadas, sob o argumento de que não foram recepcionadas pela nova Constituição, que instituiu regime expressamente acusatório, mas, ainda assim, há disposições vigentes que, ora ou outra, causam grande celeuma jurídica,

${ }^{620}$ Cf. RENATO CASAGRANDE, A urgência de um novo Código de Processo Penal in Revista de Informação Legislativa, ano 46, $\mathrm{n}^{\circ}$ 183, edição especial, julho-setembro de 2009, p. 189.

${ }^{621}$ Eis o referido excerto da Exposição de Motivos do Código de Processo Penal de 1941: "De par com a necessidade de coordenação sistemática das regras do processo penal num Código único para todo o Brasil, impunha-se o seu ajustamento ao objetivo de maior eficiência e energia da ação repressiva do Estado contra os que delinqüem. As nossas vigentes leis de processo penal asseguram aos réus, ainda que colhidos em flagrante ou confundidos pela evidência das provas, um tão extenso catálogo de garantias e favores, que a repressão se torna, necessariamente, defeituosa e retardatária, decorrendo dai um indireto estímulo à expansão da criminalidade. Urge que seja abolida a injustificável primazia do interesse do individuo sobre o da tutela social. Não se pode continuar a contemporizar com pseudodireitos individuais em prejuizo do bem comum. O indivíduo, principalmente quando vem de se mostrar rebelde à disciplina jurídico-penal da vida em sociedade, não pode invocar, em face do Estado, outras franquias ou imunidades além daquelas que o assegurem contra o exercício do poder público fora da medida reclamada pelo interesse social".

${ }^{622}$ Nesse sentido, JACINTO NELSON DE MIRANDA COUTINHO enfatiza que "o sistema processual penal brasileiro, assentado no CPP de 41 (cópia do Código Rocco, da Itália, de 1930, o fascista Vincenzo Manzini na dianteira), tem por base - e sempre teve - a estrutura inquisitorial”. Cf. Cada parte no lugar constitucionalmente demarcado in Revista de Informação Legislativa, ano 46, $\mathrm{n}^{\circ} 183$, edição especial, julhosetembro de 2009, p. 109.

${ }^{623}$ Cf. ANTONIO MAGAlHÃeS GOMES FILHO, Princípios gerais da prova no Projeto de Código de Processo Penal in Revista de Informação Legislativa, ano 46, $\mathrm{n}^{\circ} 183$, edição especial, julho-setembro de 2009, p. 36. 
pois, na prática, afiguram-se potencialmente lesivas não apenas ao sistema instaurado em 1988, mas, principalmente, aos imputados em geral.

Fala-se muito, ainda, que o processo penal brasileiro, tal como posto, é lento e ineficiente, permeado de formalidades legais desnecessárias, e que não disponibiliza instrumentos adequados nem de repressão à criminalidade moderna e organizada, nem de defesa plena aos investigados e acusados em geral $^{624}$.

Nota-se, portanto, que o Código vigente contém previsões vetustas, ultrapassadas e, mais do que isto, incompatíveis com o regime democrático instaurado em nossa Nação com o advento da Constituição Federal de 1988.

Algumas dessas disposições, como já dito, não têm sido mais aplicadas, porque se entende que não foram recepcionadas pela novel Constituição. Alterações pontuais também já foram realizadas a fim de harmonizar a legislação processual penal infraconstitucional com a Carta Magna. Aventou-se, ainda, a possibilidade de realizar amplas e abrangentes reformas do Código de Processo Penal, a fim de suprimir seus aspectos mais falhos.

Nesse último escopo, diversos projetos de lei foram elaborados, alguns dos quais redigidos por comissões de juristas das mais abalizadas. Ganharam destaque os projetos de reforma do CPP de 1994 e de 2000, o primeiro cuja comissão de anteprojetos foi presidida por Sálvio de Figueiredo Teixeira e o segundo, encabeçado por Ada Pellegrini Grinover, mas que contou com muitos membros que participaram da formulação dos anteprojetos da comissão anterior.

O conteúdo desses projetos, e as razões pelas quais os mesmos não vingaram plenamente, não serão aqui objeto de análise detida, por fugir demais ao fim deste trabalho. No entanto, merecem ser ao menos mencionadas as principais disposições desses projetos relativas ao tema da investigação criminal.

Nas propostas de reforma de 1994, nítidas eram as preocupações com uma disciplina mais detalhada do procedimento investigativo, e que lhe conferisse maior eficácia. Também se cogitou da obrigatoriedade de fundamentação, pela autoridade policial, do ato de indiciamento, da substituição do inquérito policial pela autuação sumária

624 GERALDO PRADO aludiu ainda à insuficiência do diploma na sociedade de massas atual, "industrializada e de conhecimento e de informação”. Cf. Sobre o Projeto de Código de Processo Penal in Revista de Informação Legislativa, ano 46, n 183, edição especial, julho-setembro de 2009, p. 95. 
(idéia que se aproximava do atual termo circunstanciado da Lei n. 9.099/95) e de medidas diversas relacionadas à instauração do inquérito, sua tramitação e arquivamento ${ }^{625}$.

Já o projeto da Comissão Pellegrini, atento ao fato de que o inquérito policial não constitui o único meio admitido de instrução preliminar, sugeriu a adoção de um Título específico no CPP para disciplinar a investigação criminal. No entanto, o projeto preferiu silenciar acerca dos legitimados para o exercício de atos de instrução preliminar, aludindo apenas à atividade da polícia nesse sentido. Como observou PETRÔNIO CALMON FILHO ao analisar o projeto, "a polêmica tese sobre a transferência da responsabilidade pela investigação criminal para o Ministério Público não foi absorvida pela Comissão. O projeto define, precisamente, os papéis concernentes à persecução penal. Simplificando a linguagem, a polícia investiga, o promotor acusa e o juiz julga. Por outro lado, seguindo a técnica de freios e contrapesos, foi estabelecido um certo equilíbrio, com vistas a valorizar as atividades de controle (transparência) e, acima de tudo, proporcionar agilidade à investigação" ${ }^{, 626}$.

O trabalho empreendido pela Comissão Pellegrini redundou em vários projetos de lei, um dos quais o de $n^{\circ} 4.209 / 2001$, que, ressalte-se, não tratou de um novo Código de Processo Penal, mas sim de uma reforma com vistas a alterar dispositivos específicos do Código vigente, relativos à investigação criminal ${ }^{627}$.

Não obstante as nobres tentativas empreendidas pelos juristas pátrios de modificar mais profundamente nosso sistema processual penal, de modo a não apenas modernizá-lo, tornando-o mais célere e eficiente, mas também a compatibilizá-lo com a Constituição vigente, mostrou-se praticamente impossível apagar todos os resquícios do sistema autoritário e repressivo instaurado pelo Código de 1941 sem sua completa alteração.

\footnotetext{
${ }^{625}$ Maiores informações sobre este projeto podem sem obtidas no estudo de EDUARDO REALE FERRARI, Código de Processo Penal - Comentários aos projetos de reforma legislativa, São Paulo, Ed. Millenium, 2003, pp. 09-12.

${ }^{626}$ Cf. A investigação criminal na reforma do Código de Processo Penal in Revista Brasileira de Ciências Criminais, $\mathrm{n}^{\circ}$ 34, São Paulo, Revista dos Tribunais, abril-junho de 2001, p. 82.

${ }^{627}$ Sobre este projeto de reforma do CPP, veja-se ainda ROGÉRIO LAURIA TUCCI, Investigação criminal no projeto de reforma do Código de Processo Penal in Revista do Advogado, $\mathrm{n}^{\circ} 78$, ano XXIV, setembro de 2004, pp. 103-110, e HERÁCLITO ANTONIO MOSSIN, Aspectos relevantes no projeto de reforma do Código de Processo Penal em tema de investigação in Revista CEJAP, ano 3, $\mathrm{n}^{\circ} 5$, novembro de 2002, pp. 03-15.
} 
Além disso, a prática evidenciou que modificações esparsas e pontuais do Código de Processo Penal acabam por retirar a completude e a logicidade do sistema, que fica fragmentado e muitas vezes contraditório em seus termos.

Daí porque já há algum tempo cogita-se de um novo Código de Processo Penal. Foi apenas no ano de 2009 que a comissão de juristas capitaneada por Hamilton Carvalhido, e que contou com a presença de Antonio Magalhães Gomes Filho e Jacinto Nelson de Miranda Coutinho, entre outros, apresentou um anteprojeto de reforma do Código de Processo Penal, convertido no Projeto de Lei do Senado n 156, de 2009.

Um dos principais destaques deste Projeto de Reforma do CPP é a ênfase atribuída à adoção do princípio acusatório ${ }^{628}$, com a expressa vedação tanto à iniciativa do juiz na fase investigatória ${ }^{629}$ como à substituição da atuação probatória do Ministério Público $^{630}$.

Também têm sido lembrados como importantes modificações trazidas pelo Projeto a previsão de um juiz de garantias ${ }^{631}$, a melhor definição da situação jurídica do indiciado $^{632}$, a extinção da ação penal privada ${ }^{633}$, a previsão de medidas cautelares diversas da prisão preventiva ${ }^{634}$, a limitação do cabimento do habeas corpus às hipóteses ligadas ao direito de locomoção ${ }^{635}$, a aplicação de pena privativa de liberdade por consenso no procedimento sumário ${ }^{636}$, entre outros.

${ }^{628}$ Para JACINTO NELSON DE MIRANDA COUTINHO, a mais relevante alteração no CPP vindouro é justamente a mudança para o sistema acusatório. Cf. Anotações pontuais sobre a reforma global do CPP in Boletim do Instituto Brasileiro de Ciências Criminais, ano 18, Edição Especial, agosto de 2010, pp. 16-17. A alteração referida vem consubstanciada no art. $4^{\circ}$ do Projeto, que prevê que "o processo penal terá estrutura acusatória, nos limites definidos neste Código, vedada a iniciativa do juiz na fase de investigação e a substituição da atuação probatória do órgão de acusação."

${ }^{629}$ Cf. FLÁVIA RAHAL, Questões gerais da reforma do Código de Processo Penal in Revista do Advogado, no 113, ano XXXI, setembro de 2011, pp. 63-64.

${ }^{630} \mathrm{Cf}$. ANTONIO MAGALHÃES GOMES FILHO, Breves anotações sobre a temática das provas no Projeto de Código de Processo Penal (Projeto $n^{\circ} 156 / 2009$ do Senado Federal) in Revista do Advogado, $\mathrm{n}^{\circ}$ 113, ano XXXI, setembro de 2011, p. 36.

${ }^{631}$ Cf. MAURÍCIO ZANÓIDE DE MORAES, Quem tem medo do "juiz das garantias"? in Boletim do Instituto Brasileiro de Ciências Criminais, ano 18, Edição Especial, agosto de 2010, pp. 21-23.

${ }^{632}$ Cf. HELENA SCHIESSL CARDOSO, O inquérito policial no Anteprojeto do Código de Processo Penal: será possível abrir mão do defensor no interrogatório policial? in $\mathrm{O}$ novo processo penal à luz da Constituição (Análise crítica do Projeto de Lei ${ }^{\circ}$ 156/2009, do Senado Federal), Rio de Janeiro, Lumen Juris, 2010, p. 63.

${ }^{633}$ Cf. ALBERTO ZACHARIAS TORON, Inquérito só no MP e bye, bye ação penal privada in Boletim do Instituto Brasileiro de Ciências Criminais, ano 18, Edição Especial, agosto de 2010, pp. 03-05.

${ }^{634}$ Cf. PIERPAOLO CRUZ BOTTINI, Cautelares: superação da mediocre dicotomia in Boletim do Instituto Brasileiro de Ciências Criminais, ano 18, Edição Especial, agosto de 2010, p. 26.

${ }^{635}$ Cf. OG FERNANDES, $O$ habeas corpus no projeto do CPP in Boletim do Instituto Brasileiro de Ciências Criminais, ano 18, Edição Especial, agosto de 2010, pp. 24-25.

${ }^{636}$ Cf. ANTONIO SCARANCE FERNANDES, Procedimentos do Código originário ao Código projetado in Revista do Advogado, $n^{\circ}$ 113, ano XXXI, setembro de 2011, p. 60. 
Em matéria de investigação criminal, a própria Exposição de Motivos do Projeto dá destaque à alteração na tramitação do inquérito policial, cuja passagem pelo Poder Judiciário deixa de ser exigida ao argumento de que a função precípua da investigação é a formação da opinio delicti do Parquet. Também mereceu menção expressa na Exposição de Motivos do Projeto o fim do controle judicial sobre o arquivamento do inquérito policial ou das peças de informação.

Foi igualmente apontada como importante inovação trazida pelo Projeto a alusão à identificação das fontes de prova como objeto da instrução preliminar, referência esta que permite distinguir claramente atos de prova de atos de investigação, e salienta a idéia da prova como resultado do exercício pleno contraditório na fase processual da persecução $^{637}$.

Em relação aos legitimados ao exercício da investigação criminal, o Projeto inicialmente previu em seu art. $9^{\circ}$ que a autoridade competente para conduzir a investigação criminal, os procedimentos a serem observados e o seu prazo de encerramento seriam definidos em lei.

Ao analisar o aludido art. $9^{\circ}$, houve quem entendesse que, como o Projeto não qualificou a autoridade que deveria conduzir a investigação criminal, o Ministério Público, evidentemente, poderia dirigi-la ${ }^{638}$.

Parece, no entanto, mais acertada a interpretação segundo a qual, ao redigir o aludido dispositivo, a Comissão de Juristas que elaborou o Projeto de novo Código preferiu não atribuir expressamente ao Parquet poderes investigatórios, nem vedar de pronto tal possibilidade, relegando as discussões sobre a matéria à futura e eventual lei específica para tanto. Imagina-se, aqui, que a questão não deve ter sido alvo de consenso entre os juristas responsáveis pela formulação do Projeto.

Pois bem, foram propostas diversas Emendas e oferecidos vários pareceres ao Projeto original, que redundaram num Substitutivo. A versão final do Projeto de Lei do Senado $n^{\circ} 156 / 2009$, aprovada em tal Casa legislativa, foi então enviada à Câmara dos Deputados, e lá passou a tramitar como Projeto de Lei no 8.045/2010.

${ }^{637}$ Cf. MAURÍCIO STEGEMANN DIETER, O sistema de investigação criminal brasileiro e o novo Código de Processo Penal que se anuncia in O novo processo penal à luz da Constituição (Análise crítica do Projeto de Lei n $^{\circ}$ 156/2009, do Senado Federal), Rio de Janeiro, Lumen Juris, 2010, p. 55.

${ }^{638}$ Cf. HELENA SCHIESSL CARDOSO, O inquérito policial no Anteprojeto do Código de Processo Penal: será possivel abrir mão do defensor no interrogatório policial? in $\mathrm{O}$ novo processo penal à luz da Constituição (Análise crítica do Projeto de Lei $n^{\circ}$ 156/2009, do Senado Federal), Rio de Janeiro, Lumen Juris, 2010, p. 62. 
Atualmente, o aludido Projeto está paralisado (na verdade, assim se encontra há cerca de um ano), mas em dezembro de 2011 foi apresentado um Requerimento ao Presidente da Câmara dos Deputados solicitando a criação de uma Comissão Especial para analisar o Projeto, a fim de que seu andamento seja logo retomado $^{639}$.

De qualquer modo, importa salientar que do texto que atualmente tramita no Congresso Nacional, foi suprimido o teor do mencionado artigo $9^{\circ}$, ao passo que o art. 18 , $\S 2^{\circ}$ passou a conter previsão praticamente idêntica à existente no CPP vigente, no sentido de que a atribuição incumbida à polícia judiciária de apurar infrações penais e sua autoria não excluirá a de outras autoridades administrativas, a quem por lei seja cometida a mesma função.

Talvez se tenha optado por não trazer para o Projeto de novo CPP a questão da realização de investigações criminais pelo Ministério Público, a fim de que o mesmo pudesse ser aprovado com maior facilidade, pois, sabidamente, há interesses corporativos muito fortes em jogo.

Preferiu o legislador postergar a discussão para outro momento, o que é até compreensível, mas não deixa de ser criticável, pois foi perdida uma excelente oportunidade de prever expressamente em lei e, mais do que isto, regulamentar tais investigações que vêm sendo realizadas na prática, e cuja legalidade já foi alvo de reconhecimento mais de uma vez pelo Supremo Tribunal Federal ${ }^{640}$.

Há quem enxergue, porém, no Projeto de novo Código de Processo Penal, tal como redigido, a atribuição ao Parquet da responsabilidade direta pela investigação criminal, como destinatário final de tal atividade. Para PAULO CÉSAR BUSATO, por exemplo, o tratamento dado ao tema do arquivamento do inquérito policial e a própria forma com que os títulos e capítulos foram dispostos no Projeto denota a capacidade investigatória do Ministério Público, já que foi fixada no Título II a investigação criminal

\footnotetext{
${ }^{639}$ Tal é a situação atual do Projeto, segundo informação veiculada no site oficial da Câmara dos Deputados, disponível [on line] in http://www.camara.gov.br/proposicoesWeb/fichadetramitacao?idProposicao=490263 [28-12-11].

${ }^{640}$ Ao tratar do assunto, GERALDO PRADO fez as seguintes observações e questionamentos: “Com efeito, o PLS 156/09 deixou de tomar partido na questão da direção da investigação criminal, remetendo à lei (art. $\left.9^{\circ}\right)$. Mas, que lei? Por que não o próprio Código de Processo Penal, que reivindica reserva - e monopólio infraconstitucional das regras de processo?". Cf. Sobre o Projeto de Código de Processo Penal in Revista de Informação Legislativa, ano 46, nº 183, edição especial, julho-setembro de 2009, p. 99.
} 
como gênero, do qual seria espécie o inquérito policial, referido no Capítulo III do mesmo Título $^{641}$.

Segundo o jurista, também demonstra que o Projeto incumbiu o Parquet de comandar a instrução preliminar a constante referência à "autoridade" como autora da investigação, sem alusão expressa à "autoridade policial". Mas, mais do que isto, para o autor, é possível concluir que o Projeto possibilitou a direção da investigação criminal ao Ministério Público por conta de seu tratamento como efetiva parte no processo penal. Em suas próprias palavras, "se o sujeito processual encarregado da acusação é o Ministério Público e esta é a sua posição como o sujeito do processo, é óbvio que a ele incumbe o comando da investigação criminal, exercendo não só o poder de seleção e organização das provas a serem apresentadas com o caso ao judiciário, como ainda exercendo sua tarefa constitucional primordial de controle externo da atividade policial, também no campo da investigação" ${ }^{\circ 42}$.

Ainda sobre o tema, oportuno mencionar que o Instituto Brasileiro de Direito Processual (IBDP) apresentou diversas propostas de emendas ao Projeto de lei de Código de Processo Penal. Uma delas sugeriu a modificação do já referido $\S 2^{\circ}$ do art. 18 do Projeto, para que dele constasse a seguinte redação: "a competência definida neste artigo não excluirá a do Ministério Público e de autoridades administrativas, a quem por lei seja cometida a mesma função".

A justificativa apresentada para a mudança proposta foi a "necessidade de estabelecer que o exercício da atividade de polícia judiciária pelos delegados de polícia não exclua a competência do Ministério Público e outra autoridade administrativa para também realizarem a investigação. Todavia, para tanto, a redação deveria mencionar, expressamente, tal possibilidade, na medida em que, segundo a disciplina constitucional

\footnotetext{
${ }^{641}$ Cf. De magistrados, inquisidores, promotores de justiça e samambaias - Um estudo sobre os sujeitos no processo em um sistema acusatório in $\mathrm{O}$ novo processo penal à luz da Constituição (Análise crítica do Projeto de Lei n ${ }^{\circ}$ 156/2009, do Senado Federal), Rio de Janeiro, Lumen Juris, 2010, p. 121. Explica ainda o autor que o inquérito policial é o mais importante instrumento na composição da investigação endereçada ao Parquet, o que não significa que seja o único, ou que o Ministério Público dependa do inquérito policial para formar sua opinio delicti.

${ }^{642}$ Cf. De magistrados, inquisidores, promotores de justiça e samambaias - Um estudo sobre os sujeitos no processo em um sistema acusatório in $\mathrm{O}$ novo processo penal à luz da Constituição (Análise crítica do Projeto de Lei n ${ }^{\circ}$ 156/2009, do Senado Federal), Rio de Janeiro, Lumen Juris, 2010, p. 122.
} 
brasileira, o Ministério Público não é órgão da Administração Publica ou autoridade administrativa ${ }^{, 643}$.

Não se desconhece, ainda, a existência de opiniões no sentido de que o Projeto deveria, na verdade, ter vedado expressamente ao Ministério Público o exercício do direito à investigação ${ }^{644}$.

Se, de um lado, o Projeto não contemplou, ao menos explicitamente, as investigações ministeriais, de outro lado, permitiu expressamente a realização de investigação criminal pela defesa. A previsão, contida no art. 14 do projeto original e um pouco modificada no art. 13 da versão atual, faculta ao investigado, por meio de seu advogado, de defensor público ou de outros mandatários com poderes expressos, tomar a iniciativa de identificar fontes de prova em favor de sua defesa, podendo inclusive entrevistar pessoas.

$\mathrm{O} \S 1^{\circ}$ do dispositivo, em sua redação mais recente, acrescenta ainda que as entrevistas realizadas na forma do caput do artigo deverão ser precedidas de esclarecimentos sobre seus objetivos e do consentimento das pessoas ouvidas.

Ao analisar o aludido preceito legal, observa MAURÍCIO STEGEMANN DIETER que o mesmo "garante ao investigado o direito de se socorrer na própria astúcia para identificação de fontes de prova de modo ativo, identificando - pessoalmente ou por meio de seus procuradores - fontes de prova em seu favor, inclusive na forma especifica de entrevistas com potenciais testemunhas, bastando para validá-las o esclarecimento do propósito que cumprem ao falar e o consentimento" ${ }^{\circ 45}$.

A previsão, claramente inspirada nas investigações defensivas estatuídas pelo ordenamento jurídico italiano, ao menos assegura maior equilíbrio e igualdade entre

${ }^{643}$ Cf. INSTITUTO BRASILEIRO DE DIREITO PROCESSUAL (IBDP), Propostas de emendas ao Projeto de lei de Código de Processo Penal - Substitutivo da CCJ do Senado, Presidência de Ada Pellegrini Grinover, 2010. Disponível [on line] in http://direitoprocessual.org.br/content/blocos/96/1 [29/12/2011]

${ }^{644} \mathrm{Em}$ parecer formulado pelo Instituto dos Advogados Brasileiros (IAB), defendeu-se o posicionamento segundo o qual faltou ao Projeto "uma vedação expressa e categórica de investigação criminal pelo Ministério Público, que na relação processual penal é parte e não "fiscal da lei"”, e por isso estaria "tão empenhado em fazer valer sua pretensão punitiva quanto o advogado do réu contra ela resistir". Cf. INSTITUTO DOS ADVOGADOS BRASILEIROS, Parecer da Comissão Permanente de Direito Penal do Instituto dos Advogados Brasileiros ao Projeto de Lei do Senado $n^{\circ}$ 156/2009 que institui o novo Código de Processo Penal, coord. Fernando Fragoso, Rio de Janeiro, 2010, p. 19.

${ }^{645}$ Cf. O sistema de investigação criminal brasileiro e o novo Código de Processo Penal que se anuncia in $\mathrm{O}$ novo processo penal à luz da Constituição (Análise crítica do Projeto de Lei n ${ }^{\circ}$ 156/2009, do Senado Federal), Rio de Janeiro, Lumen Juris, 2010, p. 56. Semelhante é a opinião de ANTONIO RUIZ FILHO, para quem a inovadora previsão da investigação defensiva "retira o investigado da condição incômoda de mero espectador da própria persecução". Cf. Observações sobre o novo processo penal in Revista do Advogado, $\mathrm{n}^{\circ} 113$, ano XXXI, setembro de 2011, p. 48. 
acusação e defesa na fase inicial da persecução penal, pois, embora a instrução preliminar a cargo do Parquet não tenha sido contemplada pelo Projeto, imagina-se que continuará sendo realizada, tal como tem ocorrido hoje, mesmo na ausência de previsão legal.

Necessário ainda mencionar que da redação original do Projeto de novo CPP não constava nenhum outro detalhamento acerca da investigação defensiva. No entanto, após alterações promovidas ainda no Senado Federal, o art. 13 do Projeto passou a contar com uma série de parágrafos que objetivaram disciplinar mais minuciosamente o exercício do direito à investigação pela defesa.

Passou-se a prever, por exemplo, que a vítima não poderá ser interpelada para fins de investigação defensiva, salvo se houver autorização do juiz de garantias, que deverá, se o caso, fixar condições para a realização da entrevista, devendo sempre ser resguardado o consentimento da vítima ( $\$ \S 2^{\circ}$ e $3^{\circ}$ do art. 13$)$.

O dispositivo estabeleceu ainda que os pedidos de entrevista deverão ser feitos com discrição e reserva, em dias úteis e no horário comercial, que o material produzido poderá ser juntado aos autos do inquérito, a critério da autoridade policial, e que as pessoas habilitadas à realização das investigações (advogado, defensor público ou outros mandatários com poderes expressos) responderão civil, criminal e disciplinarmente pelos excessos cometidos $\left(\S \S 4^{\circ}, 5^{\circ}\right.$ e $6^{\circ}$ do art. 13$)$.

Louvável a preocupação dos legisladores com a proteção da vítima e com o cometimento de abusos por parte dos profissionais que efetuarão diretamente as diligências investigatórias defensivas. De fato, o ofendido deve ser resguardado contra eventuais investidas arbitrárias resultantes da instrução preliminar a cargo da defesa, e a previsão de que os legitimados à realização dos atos investigativos poderão ser responsabilizados pelos excessos cometidos, longe de ser redundante, serve de alerta para que abusos no exercício de tal mister sejam evitados.

Passível de críticas, porém, a previsão de que o material colhido na investigação defensiva poderá ser juntado aos autos do inquérito, a critério da autoridade policial. Ora, se os elementos de informação obtidos pela defesa só puderem ser considerados caso juntados aos autos do inquérito, e se tal juntada ficar submetida ao juízo discricionário da autoridade policial, a realização de investigação própria pela defesa poderá muitas vezes se revelar inútil, pois quando o delegado de polícia houver por bem 
não colacionar aos autos do inquérito os informes trazidos pela defesa, os mesmos sequer serão conhecidos ou apreciados por quem de direito.

Lembre-se ainda da experiência italiana, onde se percebeu que o encaminhamento da investigação defensiva ao Ministério Público acabava por tolher sua efetividade e frustrar seus objetivos, além do que acentuava a disparidade de tratamento entre acusação e defesa ${ }^{646}$. E mesmo a posterior previsão, no ordenamento jurídico daquele país, de que os elementos colhidos na investigação defensiva deveriam ser endereçados ao juiz e não mais ao Parquet, e de que tal documentação deveria ser inserida nos autos da instrução preliminar ${ }^{647}$, não foi suficiente para conferir efetividade plena ao exercício do direito à investigação pela defesa. Como visto ${ }^{648}$, tal objetivo só foi alcançado depois que a investigação defensiva foi minuciosamente regulamentada.

Indaga-se, portanto, se, a exemplo do que ocorreu na Itália num primeiro momento, a mera referência legal à investigação defensiva, sem detalhada disciplina dos modos através dos quais tal atividade será exercida, não será insuficiente à sua efetiva concretização. Ao que tudo indica, a ausência de regulamentação pormenorizada do procedimento investigativo da defesa poderá esvaziar o conteúdo da norma que o prevê.

Quanto à vítima, embora o Projeto de novo Código de Processo Penal tenha lhe dedicado especial atenção, tratando de seus direitos em capítulo específico do diploma (Título V do Livro I), não lhe foi atribuída expressamente a prerrogativa de realizar suas próprias investigações criminais. Entre os direitos arrolados no art. 91 do texto, já na versão atual, não se previu o direito à investigação. Apenas o art. 26 do Projeto assegura ao ofendido o direito hoje já existente de requerer a realização de diligência à autoridade policial, a ser realizada quando reconhecida sua necessidade.

Ainda em matéria de investigação criminal, o Projeto assegurou também à vítima o direito de obter cópias de peças do inquérito policial, de peticionar às autoridades públicas para informar-se a respeito do andamento e deslinde da investigação, bem como de manifestar sua opinião.

É válido ainda mencionar que o Projeto inovou ao prever a possibilidade de o ofendido participar do processo penal como parte civil, e não apenas como assistente do

${ }^{646}$ Cf. PASQUALE VENTURA, Le indagine difensive, Milano, Giuffrè, 2005, pp. 09-16.

${ }^{647} \mathrm{Cf}$. ANDRÉ AUGUSTO MENDES MACHADO, Investigação criminal defensiva, São Paulo, Revista dos Tribunais, 2010, p. 146.

${ }^{648}$ Ver item 3.2.3.1. 
Ministério Público. Atuando apenas naquela primeira condição, a vítima limitar-se-á a postular a satisfação do dano moral sofrido em decorrência do ilícito penal, ao passo que como assistente, o pleito indenizatório formulado pelo ofendido pode ser mais amplo.

Em outras palavras, a diferença entre a atuação da vítima como parte civil e como assistente seria a de que, no primeiro caso, buscar-se-ia somente o reconhecimento do dano moral, e na própria sentença criminal, ao passo que, na segunda hipótese, haveria interesse na constituição do título executivo penal de modo genérico, para satisfação do crédito no âmbito civil ${ }^{649}$.

A propósito, ao tratar da figura do assistente no art. 77, o Projeto praticamente repetiu a regra hoje vigente que permite à vítima, seu representante legal (em caso de menoridade ou incapacidade) ou seus herdeiros (em caso de morte ou ausência) intervir como assistente do Ministério Público em todos os termos do "processo penal". Esta última expressão excluiria, a princípio, o ingresso do ofendido já na fase de instrução preliminar, tal como ocorre hodiernamente, por força do disposto no art. 268 do CPP em vigor.

É imperioso, ainda, chamar a atenção para o fato de que algumas disposições constantes do Projeto de novo Código de Processo Penal parecem restringir a atuação da vítima, no papel de assistente, à satisfação de seus interesses patrimoniais, o que contraria a orientação hoje reinante na doutrina pátria, no sentido de que o ofendido também visa à correta aplicação da lei penal ao auxiliar o Ministério Público na acusação.

É o art. 79 da versão atual do Projeto que permite extrair a conclusão de que a vítima só poderia intervir no processo penal para satisfazer sua pretensão civil. Afinal, o caput do dispositivo estabelece que o assistente de acusação só poderá arrazoar os recursos interpostos pelo Parquet ou por ele próprio nas hipóteses de absolvição, de absolvição sumária, de impronúncia e de extinção da punibilidade, e o $\S 3^{\circ}$ do mesmo art. 79 dispõe que o recurso do assistente será limitado ao reconhecimento da autoria e da existência do fato.

Ao analisar aludidos preceitos, asseverou LUIS GUSTAVO GRANDINETTI CASTANHO DE CARVALHO que, no Projeto de novo CPP, a

${ }^{649}$ Cf. LUIS GUSTAVO GRANDINETTI CASTANHO DE CARVALHO, Quando o público e o privado se encontram no Projeto: assistência, indenização e composição in $\mathrm{O}$ novo processo penal à luz da Constituição (Análise crítica do Projeto de Lei n ${ }^{\circ}$ 156/2009, do Senado Federal), Rio de Janeiro, Lumen Juris, 2010, pp. 318-319. 
finalidade da assistência é obter uma sentença penal que melhor proteja o interesse da vítima de recompor o dano causado pela infração penal, quer seja ele exclusivamente moral (e por isto objeto da própria sentença penal), quer seja também de ordem material (a ser liquidado e executado no juízo cível). Tanto o interesse da vítima na persecução penal seria exclusivamente patrimonial, segundo o jurista, que o Projeto proibiu expressamente a interposição de recurso pelo assistente para discutir a quantidade e a qualidade da pena ${ }^{650}$.

Há, no entanto, quem sustente que, mesmo em face das mudanças propostas pelo Projeto de novo CPP relativas à figura do assistente, a atuação da vítima na persecução penal não se resume à obtenção de uma sentença penal condenatória para fins de satisfação de seus interesses civis, seria mais ampla. Este entendimento seria compatível com o tratamento conferido à vítima pela Constituição Federal de 1988, e corroborado pelo fato de o Projeto assegurar uma imensa gama de direitos ao ofendido, os quais abrangem, além da reparação dos danos, o direito à informação, à preservação da intimidade, da integridade física e mental, e à própria participação no processo penal ${ }^{651}$.

Ainda em relação à vítima, mostra-se imperioso recordar que o Projeto de novo Código de Processo Penal não mais permite sua intervenção no processo penal na condição de querelante, uma vez que a ação penal exclusivamente privada deixa existir no referido diploma. A exclusão, aliás, foi alvo de críticas, uma vez que contraria, de certo modo, uma tendência verificada em todo o mundo de valorização do ofendido e de seus interesses no processo penal.

A justificativa apresentada na Exposição de Motivos do Projeto para a extinção da ação penal exclusivamente privada é a de que não "parece haver lugar para uma ação penal que esteja à disposição dos interesses e motivações do particular, ainda que seja a vítima. Eventual necessidade de aplicação de sanção penal somente se legitima no interesse público”.

Para ALBERTO ZACHARIAS TORON, o Projeto, neste ponto, simplesmente confundiu interesse público na punição e as razões que ditam a persecução

\footnotetext{
${ }^{650}$ Cf. Quando o público e o privado se encontram no Projeto: assistência, indenização e composição in $\mathrm{O}$ novo processo penal à luz da Constituição (Análise crítica do Projeto de Lei n ${ }^{0}$ 156/2009, do Senado Federal), Rio de Janeiro, Lumen Juris, 2010, p. 317.

${ }^{651}$ Cf. FLAVIANE DE MAGALHÃES BARROS, Direito das vitimas e sua participação no processo penal: a análise do PLS 156/2009 a partir de uma interpretação constitucional in O novo processo penal à luz da Constituição (Análise crítica do Projeto de Lei n ${ }^{\circ}$ 156/2009, do Senado Federal), Rio de Janeiro, Lumen Juris, 2010, pp. 326-327.
} 
penal privada, que são de outra ordem, sendo que, o que se permite à vítima neste último caso é a persecução penal; o direito de punir é conservado nas mãos do Estado ${ }^{652}$.

Seja como for, não se pode negar os relevantes avanços trazidos pela disciplina da investigação criminal no Projeto de novo Código de Processo Penal. Este, ao procurar dar maior concretude ao princípio acusatório em nosso sistema, reforçou o papel de cada um dos sujeitos processuais: vedou a iniciativa do juiz na investigação criminal, restringindo a atuação do Judiciário nesta fase ao exercício das funções do juiz de garantia, atribuiu ao Parquet verdadeira condição de parte já durante a instrução preliminar prévia, tanto que o trâmite do inquérito policial se dá diretamente entre polícia e Ministério Público, e o arquivamento da aludida peça não é mais submetido à apreciação judicial, e possibilitou expressamente à defesa exercer seu direito à investigação, colhendo fontes de prova em seu favor através, inclusive, de entrevistas com potenciais testemunhas.

Essas mudanças certamente trarão benefícios não apenas ao desenvolvimento das funções e finalidades de cada uma das partes, mas também imprimirão um viés mais democrático ao nosso sistema processual penal, com efetiva participação de todos os envolvidos.

A julgar pelos dispositivos do Projeto de novo Código de Processo Penal, os papéis da acusação, da defesa e do Estado-juiz estarão melhor demarcados no sistema que se instalará e, por isto mesmo, poderão ser exercidos de modo a conciliar o interesse estatal na persecução penal e os direitos e garantias fundamentais dos cidadãos investigados e acusados em geral.

Criticável, porém, o fato de o Projeto não prever expressamente o direito à investigação do Ministério Público e da vítima, sendo que o último poderia, certamente, ser assegurado de forma limitada nos crimes de ação penal pública, e também o fato de o Projeto não disciplinar detalhadamente o procedimento segundo o qual se realizará a investigação defensiva, pelas razões já expostas.

${ }^{652} \mathrm{Cf}$. Inquérito só no MP e bye, bye ação penal privada in Boletim do Instituto Brasileiro de Ciências Criminais, ano 18, Edição Especial, agosto de 2010, p. 04. A jurista FLAVIANE DE MAGALHÃES BARROS também criticou a alteração promovida pelo Projeto. Cf. Direito das vítimas e sua participação no processo penal: a análise do PLS 156/2009 a partir de uma interpretação constitucional in O novo processo penal à luz da Constituição (Análise crítica do Projeto de Lei n ${ }^{\circ}$ 156/2009, do Senado Federal), Rio de Janeiro, Lumen Juris, 2010, p. 329. 


\section{CONCLUSÃO}

A investigação criminal é tema dos mais caros e instigantes no âmbito da ciência processual penal, e tem sido objeto de estudo pela doutrina pátria nos últimos anos sob os mais variados aspectos. Ocorre, porém, que, usualmente, a investigação é abordada meramente como a fase extrajudicial da persecução penal, em que se objetiva a colheita de informações sobre a autoria e a materialidade do delito cometido para fins de propositura da ação penal.

O presente trabalho propôs-se a analisar a investigação criminal sob outro viés, não como etapa inicial da persecutio criminis, mas sim como um direito das partes, decorrente do próprio direito à prova. Este é um direito fundamental, garantido implicitamente pela Constituição Federal de 1988, como consectário lógico de outros direitos, entre os quais o direito ao devido processo legal previsto no art. $5^{\circ}$, LIV, o direito ao contraditório e à ampla defesa, com os meios e recursos a ela inerentes, referido no art. $5^{\circ}, \mathrm{LV}$, e o próprio direito à presunção de inocência, tratado no art. $5^{\circ}$, LVII do texto constitucional.

Oportuno ainda mencionar que a incorporação ao ordenamento jurídico brasileiro do Pacto Internacional de Direitos Civis e Políticos de 1966, e da Convenção Americana de Direitos Humanos (ou Pacto de São José da Costa Rica) de 1969, apenas veio a corroborar a existência do direito à prova e, por conseguinte, do direito à investigação, em nosso País.

Pois bem, inicialmente foram analisados os aspectos teóricos relacionados ao direito à investigação, o qual, como visto, é uma das prerrogativas inerentes ao direito à prova. Esta é uma palavra polissêmica, pois comporta diferentes significados não só na linguagem comum, mas também no âmbito da ciência processual: é possível falar-se em elementos de prova, resultados de prova, objetos de prova, fontes de prova, meios de prova, meios de investigação de prova, entre tantas outras locuções.

No que diz respeito à expressão direito à prova, consiste ela basicamente no direito das partes de utilizar, durante a persecução penal, todos os meios e instrumentos de prova disponíveis a fim de demonstrar a veracidade dos fatos alegados. Vale lembrar que o direito à prova está intrinsecamente ligado às garantias do contraditório, da ação e da 
defesa, conceitos estes que têm como ponto de convergência a constante possibilidade de participar ativamente do desenvolvimento do processo amplamente considerado.

E justamente por estar relacionado diretamente aos direitos de ação e de defesa, o direito à prova apresenta a natureza jurídica de direito público subjetivo de participar de todas as fases do procedimento probatório e de ver introduzido no processo o material produzido, de forma a influir na formação do convencimento judicial.

A propósito, são titulares do direito à prova não apenas o autor e o réu da ação penal, como poderia se supor pelo fato de o direito à prova estar diretamente relacionado aos direitos de ação e de defesa. A todas as partes de um processo penal, necessárias ou eventuais, é assegurado o direito à prova, uma vez que o objeto desta é amplo, não diz respeito apenas à autoria e à materialidade do delito, abrange também fatos pertinentes e úteis à verificação das demais alegações formuladas pelas partes, relativas a circunstâncias diversas daquelas. Logo, no processo penal brasileiro, não apenas ao autor e ao réu é assegurado o direito à prova, mas também ao assistente de acusação, único exemplo de parte eventual do processo penal brasileiro.

E quanto ao conteúdo do direito à prova, justamente por estar normalmente associado às fases do procedimento probatório é possível concluir que o direito à investigação dele advém. Afinal, são etapas da instrução não só a proposição, admissão, produção e valoração da prova, mas também sua investigação; de nada adiantaria garantir aquelas prerrogativas se não fosse permitido à partes buscar as fontes de prova, os elementos de informação que poderão servir como meios de prova durante o processo.

O direito à investigação consistiria, assim, no direito de pesquisar as fontes de prova, de investigar o material que poderá subsidiar as alegações das partes durante toda a persecução penal. E, por decorrer diretamente do direito à prova, o direito à investigação apresenta a mesma natureza jurídica daquele, qual seja a de um direito público subjetivo, e de que são titulares as possíveis partes de um futuro processo penal. Repare-se que não apenas às efetivas partes é assegurado tal direito, mas também às potenciais partes, uma vez que o direito à investigação é exercitável depois de já instaurado o processo e, principalmente, antes dele. E não se exige nem a condição de provável parte para se assegurar o direito à investigação na fase instrutória preliminar, pois também aos investigados ditos inocentes deve ser garantido tal direito, a fim de que possam demonstrar, por exemplo, a inexistência de justa causa para a ação penal. 
Aliás, é imperioso ressaltar que o exercício do direito à investigação não tem como único propósito embasar a propositura de uma demanda; talvez sua função primordial seja justamente evitar o ajuizamento de processos equivocados e descabidos, além, é claro, de fornecer supedâneo para decisões na fase instrutória preliminar. A investigação criminal própria permite ainda que as partes busquem informações que utilizarão para produzir os meios de prova durante o processo, e tracem, desde logo, suas estratégias de atuação ao longo da persecução criminal.

Como se vê, o direito à investigação tem as partes, ainda que potenciais, como titulares e também destinatários da atividade desenvolvida nesse escopo. Mais do que ao juiz, as informações colhidas no bojo de uma investigação servem ao convencimento das partes acerca da viabilidade da ação penal; apenas depois de proposta esta é que a atividade probatória se volta à formação da convicção do magistrado que julgará a causa. É por este motivo, aliás, que se pode falar na autonomia do direito à investigação, que não se vincula, necessariamente, à existência de um processo, pode existir independentemente daquele, como ocorre quando a instrução preliminar não é seguida da propositura de uma ação penal.

E não é demais ressaltar que, no exercício do direito à investigação, as possíveis partes de um processo penal colhem fontes de prova, assim entendidas as pessoas ou coisas através das quais se pode conseguir a prova. Não há verdadeira produção de meios de prova, uma vez que sua obtenção se dá de forma unilateral, muitas vezes com uso do chamado elemento-surpresa, e longe da presença do juiz, ou seja, sem a observância do contraditório.

Logo, via de regra, os elementos de informação obtidos antes de iniciado o processo não devem ser utilizados como prova em sentido estrito para a formação do convencimento do judicial, pois o contraditório não se faz presente nesta etapa da persecução penal. Admite-se, no entanto, o chamado contraditório diferido (posterior, não para a prova, mas sobre esta) nas hipóteses de produção de provas irrepetíveis, cautelares ou antecipadas, as quais muitas vezes são tratadas como sinônimo pela doutrina, mas apresentam certas distinções.

Neste sentido, provas irrepetíveis seriam, basicamente, aquelas que, uma vez realizadas, não mais podem ser reproduzidas posteriormente (por exemplo, determinadas provas periciais). Ressalte-se que, embora aceitável o contraditório diferido sobre tais provas, caso a irrepetibilidade do ato seja conhecida desde logo e afigure-se 
viável colher a prova na presença das possíveis partes e do juiz sem prejuízo de sua eficácia, deve-se, tanto quanto possível, proceder a uma espécie de incidente jurisdicionalizado na fase de instrução preliminar, à semelhança do chamado incidente probatório existente no ordenamento jurídico italiano, como forma de garantir o contraditório já na formação da prova, pois esta é a regra, não a exceção.

No Brasil, não existe figura equivalente à mencionada do processo penal italiano, mas há previsões legais de conteúdo semelhante, e que remetem às distinções entre provas cautelares e antecipadas. As primeiras seriam aquelas colhidas ad perpetuam memoriam e que visam à conservação das fontes para posterior utilização no processo, ao passo que, nas últimas, haveria verdadeira produção de prova, mas em momento anterior à fase instrutória propriamente dita. Ou seja, nas provas cautelares se visaria meramente à assecuração da fonte de prova, antes da instauração do processo e, normalmente, sem a observância do contraditório, enquanto nas provas antecipadas se realizaria verdadeira produção dos meios de prova, com a relação processual já instaurada e contraditório em sua formação, mas num momento anterior à fase instrutória propriamente dita.

Como as distinções acima referidas entre provas irrepetíveis, cautelares e antecipadas, embora possíveis, não são pacíficas, e o legislador pátrio tampouco foi rigoroso ao tratar da matéria, as expressões costumam ser tratadas como equivalentes pela doutrina brasileira.

Mencione-se também que, embora no âmbito processual civil seja defensável a produção antecipada de provas sem o requisito da urgência, no processo penal, a idéia deve ser vista com ressalvas, pois a própria dinâmica que rege o último obsta a instalação do contraditório antes de iniciado o processo, além do que não se sabe de antemão exatamente contra quem tal prova será utilizada, e mesmo a cognição plena acerca dos fatos sobre os quais versa a causa não é desejável em tal momento da persecução.

E ainda quando da análise do direito à investigação no plano teórico, viu-se que o abuso de tal direito não é, a priori, punível no processo penal pátrio, pois seus princípios, direitos e garantias próprios, como a ampla defesa e o princípio da presunção de inocência, não impõem às partes, principalmente ao imputado, rígidos deveres de veracidade, de lealdade e de colaboração processual. Ademais, lembre-se que o Ministério Público é, na maioria das vezes, o titular da ação penal, e, por ser um ente estatal, seus atos gozam de presunção de legalidade. Por tal razão, não se vislumbra, ao menos não num 
primeiro momento, a possibilidade de membros do Parquet cometerem abuso de direito processual, até porque poderiam ser responsabilizados pelos atos praticados com excesso.

Logo, não se cogita de litigância de má-fé ou da imposição, por analogia, das respectivas sanções previstas no processo civil, para as condutas que impliquem abuso de direito à investigação. Ressalte-se, porém, que a prerrogativa em análise não é absoluta, deve observar certos limites, sob pena de violar outros direitos e garantias fundamentais igualmente assegurados. Não podem as partes, no exercício de tal direito, utilizar meios de investigação de provas, ou produzir provas cautelares e antecipadas, ilícitas.

E quanto ao uso de informações obtidas através da investigação criminal por terceiros, em especial pela imprensa, trata-se de um tema muito controverso e debatido nos dias de hoje, e que envolve o conflito entre diferentes direitos fundamentais, tais como o direito à liberdade de imprensa, ao acesso à informação, à vida privada, e à publicidade dos atos administrativos e jurisdicionais, ainda que atenuada pelo sigilo das investigações em certas hipóteses.

Neste trabalho, buscou-se apenas chamar a atenção para os riscos ao investigado e à própria investigação da atuação descuidada e excessiva dos meios de comunicação ao noticiar a prática de delitos e suas circunstâncias, pois muitas vezes os suspeitos são tratados como se condenados fossem, em evidente violação ao princípio da presunção de inocência, além do que a veiculação pela mídia de determinadas informações pode comprometer o próprio sucesso de diligências que dependam do fator-surpresa para sua realização. Ressalte-se que a doutrina tem apontado diversas soluções para que os princípios e valores em jogo na divulgação pela imprensa de fatos criminosos restem assegurados no caso concreto.

Estas foram, em síntese, as principais conclusões obtidas quanto da análise do direito à investigação no plano teórico. Antes, porém, de verificar quais as repercussões práticas do reconhecimento do direito à investigação no processo penal brasileiro, procedeu-se neste estudo a uma breve análise de direito comparado, para verificação dos modos pelos quais os diferentes países tratam da matéria.

Nesse escopo, foram analisados sistemas processuais de países da Common Law e da Civil Law, e sua classificação foi feita segundo o critério do principal sujeito/instituição a quem foi incumbida a função de investigar. Os sistemas de instrução prévia ou preparatória foram, assim, divididos em três categorias: juizado de instrução, 
investigação policial e investigação ministerial. Entre elas, mereceu destaque a última, pois nela se insere a disciplina legal italiana relativa ao tema, que confere expressamente às possíveis partes de um processo penal o direito à investigação.

O regramento processual italiano guarda grande similitude com o processo penal brasileiro, de tradição continental, e tem-nos servido de inspiração para algumas alterações legislativas, contudo, mais do que isto, deve ser destacado porque contém regulamentação específica atinente ao exercício do direito à investigação. Na Itália, é reconhecido expressamente tal direito ao Ministério Público, à defesa, e à vítima, e a chamada investigação defensiva (exercitável não só pelo imputado, mas também pelo ofendido) encontrou guarida já na Constituição do país, além de ter recebido, ao longo dos anos, tratamento minucioso acerca de seu procedimento no Código de Processo Penal.

Pois bem, depois de empreendida uma rápida análise de direito comparado acerca do direito à investigação, buscou-se analisar os efeitos práticos de seu reconhecimento no ordenamento jurídico brasileiro, ou seja, os modos pelos quais cada um dos titulares de tal direito pode exercê-lo em face do ordenamento jurídico hoje vigente.

Da análise da Constituição Federal de 1988 e do Código de Processo Penal (CPP), principal diploma infraconstitucional relacionado à matéria, viu-se que o Brasil adotou o modelo de investigação policial, segundo o qual a função de apurar o cometimento de delitos foi atribuída precipuamente à polícia judiciária, exercida pela polícia civil nos Estados, e pela polícia federal no âmbito da União.

No entanto, tanto a Carta Magna como o CPP previram a possibilidade de órgãos diversos da polícia judiciária promoverem investigações criminais, a exemplo das comissões parlamentares de inquérito, da polícia militar no seu âmbito de atuação, e de muitas outras autoridades administrativas a quem foi atribuída a mesma função.

Tais modalidades de instrução preliminar são admitidas sem maiores controvérsias em nosso ordenamento jurídico, mas o mesmo não se aplica às investigações promovidas pelas possíveis partes em um processo penal, titulares do direito à investigação, constatação esta que causa certa perplexidade se consideradas as premissas teóricas expostas, segundo as quais a realização de investigações criminais constitui na verdade um direito público subjetivo das possíveis partes de um processo penal, decorrente do direito à prova. 
Seja como for, mesmo em face do ordenamento jurídico hoje vigente, é possível que as partes exerçam seu direito à investigação.

Em relação ao Ministério Público, cabe observar que a Constituição Federal de 1988 não lhe atribuiu expressamente tal direito, mas tampouco lhe proibiu de exercê-lo. A análise de todos os dispositivos constitucionais relacionados ao tema, e dos argumentos favoráveis e contrários à atribuição de tal atividade ao Parquet, permitiu concluir que a realização de atos de instrução preliminar pelos representantes da instituição é totalmente compatível com as finalidades desta, além do que constitui manifestação do direito à prova.

Idêntico raciocínio se aplica ao exame dos dispositivos infraconstitucionais concernentes ao tema. O Código de Processo Penal e as leis que regulamentam o Ministério Público tampouco atribuem expressamente poderes investigatórios criminais a seus membros. No entanto, entende-se que tal prerrogativa advém do direito à prova, e está abrangida implicitamente entre os poderes dos membros do Parquet, necessários ao alcance de suas finalidades.

Ressalte-se que apenas os atos normativos editados pelo próprio Ministério Público conferem-lhe expressamente a função de investigar delitos e disciplinam sua realização, não se tratando, porém, do veículo normativo adequado a tanto. Faz-se necessária, na verdade, uma lei geral e abstrata, complementar ou ordinária, que regulamente a matéria de modo a fixar os contornos e limites dessa atividade ministerial, evitando o risco de o Parquet selecionar arbitrariamente os casos que deseja investigar, permitindo que recursos materiais e humanos sejam disponibilizados para tal fim, e que o exercício de tal função seja fiscalizada, interna e externamente, entre tantas outras vantagens passíveis de enumeração.

Mencione-se ainda que o Supremo Tribunal Federal já reconheceu, em decisões proferidas não pelo plenário, mas por uma de suas Turmas, a constitucionalidade das investigações ministeriais, entendimento este que vem sendo adotado também pelo Superior Tribunal de Justiça e pelos demais tribunais do País.

Já no que diz respeito à investigação defensiva, carece tal direito de maior reconhecimento no ordenamento pátrio, o que se deve em grande parte às discussões em torno da própria existência ou não da garantia da ampla defesa na etapa inicial da persecução penal, em que não há processo propriamente dito. 
Após breve análise acerca da questão, concluiu-se que, mesmo não havendo contraditório ou processo na instrução preliminar, nela já se faz necessária a observância do direito de defesa, pois nesta fase extrajudicial da persecutio criminis são praticados diversos atos que podem ser considerados acusatórios em sentido amplo, e que implicam, no mais das vezes, restrição a direitos e garantias fundamentais.

Logo, o direito à investigação da defesa deve ser reconhecido como corolário tanto do direito à prova assegurado a todas as partes do processo, como do direito à ampla defesa, e mesmo como decorrência do princípio da igualdade, pois esta restaria violada caso fosse permitido apenas ao Parquet promover seus próprios atos de instrução prévia.

Lembre-se ainda que tal conclusão não colide com a previsão do Código de Processo Penal, segundo a qual o investigado poderia apenas requerer a realização de determinadas diligências na fase investigativa, a serem realizadas a critério da autoridade policial. Na verdade, o imputado pode tanto promover suas próprias investigações como solicitar a realização de determinados atos à autoridade policial, que só poderá deixar de realizá-los se forem irrelevantes ou impertinentes, e mediante decisão fundamentada do delegado responsável.

Em outras palavras, mesmo não havendo qualquer dispositivo legal a autorizar expressamente o imputado a promover investigação criminal particular, não está ele impedido de fazê-lo, pelas razões já expostas. Seria, no entanto, aconselhável que houvesse disciplina legislativa detalhada sobre tal procedimento, a fim de que o mesmo fosse realizado com maior segurança jurídica, e de que os inconvenientes comumente atribuídos a tal espécie de instrução prévia fossem afastados.

Considerações semelhantes são aplicáveis ao direito à investigação da vítima. O mesmo tampouco encontra qualquer amparo legal, sendo, aliás, vedada a intervenção do ofendido como assistente de acusação na fase extrajudicial da persecução penal.

No entanto, uma vez que a vítima também é considerada titular do direito à prova e, por conseguinte, do direito à investigação, seja na condição de parte principal da ação penal, seja na qualidade de parte eventual/colaboradora do Ministério Público, imperioso reconhecer que a ela também é facultado promover as próprias investigações, até para fins de assegurar suas pretensões civis. 
Recorde-se que o objeto da prova é amplo, não se limita à apuração da autoria e da materialidade da infração penal, compreende também outras circunstâncias relevantes a ele ligadas e que as partes tenham interesse em demonstrar. Ademais, proibir a vítima de investigar, quer na condição de futura querelante, quer na condição de futura assistente de acusação, implicaria violar o princípio da igualdade, pois o direito à investigação do Ministério Público já foi reconhecido por nossos tribunais.

Em face da legislação processual hoje em vigor, em matéria de investigação criminal, a vítima pode, indubitavelmente, requerer a instauração de inquérito policial e a realização de diligências, as quais, a exemplo do que ocorre com a defesa, só poderão deixar de ser realizadas pela autoridade policial quando infundadas, e mediante decisão motivada.

Todavia, a fim de que o direito à investigação da vítima seja plenamente assegurado, imperioso se faz permitir-lhe também a realização de seus próprios atos instrutórios, para descoberta de elementos de informação que podem levar à propositura da ação penal privada, ou da pública (quando o ofendido intervém como assistente da acusação), e mesmo para fins de tutela dos seus interesses civis. Apenas nas hipóteses de crime de ação penal pública, talvez fosse conveniente limitar a atividade instrutória da vítima, porque, nesta hipótese, ela atua na mera condição de auxiliar do Parquet, que já poderá realizar ele próprio sua investigação. A medida evitaria, ainda, que o imputado se visse em situação de patente desequilíbrio, com dois opositores realizando investigações penais contra si.

Imperioso, porém, ressaltar, que a ausência de previsão legal a contemplar o direito à investigação do ofendido também pode dificultar seu exercício. Igualmente recomendável, portanto, que houvesse regramento legal específico a tratar da matéria.

Em suma, em relação a todos os titulares do direito à investigação em nosso sistema processual penal, cumpre observar que inexiste norma legal expressa a autorizar a realização de instrução preliminar própria. A circunstância não impede, todavia, que o direito seja exercido, pois o mesmo decorre do direito à prova assegurado pela Constituição Federal vigente, e de outros direitos fundamentais correlatos.

É certo, porém, que a inexistência de menção legal e de regramento específico para o desenvolvimento de tal atividade investigativa pode tornar inútil ou ineficaz o reconhecimento do direito em análise, já que as investigações particulares teriam 
a todo tempo sua legalidade questionada, e os elementos de informação colhidos em seu seio poderiam ser simplesmente desconsiderados.

Faz-se imprescindível, assim, a criação de uma disciplina legislativa específica para tratar do procedimento das investigações criminais realizadas pelas partes de um processo penal, ainda que potenciais. A regulamentação evitaria que a legitimidade de tais atos instrutórios fosse constantemente posta em xeque, fixaria os limites dessa atividade, impediria eventual seletividade indesejável nas investigações ministeriais, conferiria às diligências particulares idêntico peso ao das investigações estatais, permitindo que suas conclusões fossem efetivamente consideradas por quem de direito, evitaria eventuais abusos por parte dos advogados, definiria os modos através dos quais a instrução preliminar particular poderia ser auxiliada pelos órgãos estatais, entre tantos outros benefícios apontados ao longo deste estudo.

O regramento minucioso da matéria, tal como verificado na Itália, também afastaria, nas investigações privadas, as críticas relativas ao risco de apresentação de elementos de informação falsos, de manipulação e alteração de dados, e de acentuação das diferenças entre litigantes ricos e pobres.

Tais observações, aliás, são muito pertinentes na atualidade, uma vez que se encontra em tramitação no Congresso Nacional um projeto de lei de novo Código de Processo Penal, o qual traz algumas inovações em matéria de investigação criminal, mas silencia a respeito de muitas questões que mereciam atenção legislativa.

O Projeto, por exemplo, não alude à possibilidade de o Ministério Público ou a vitima promoverem suas próprias investigações criminais, mas contempla a defesa com tal direito, trazendo regras que, de um lado, servem de alento em relação ao atual cenário brasileiro, marcado pela escassez de normas atinentes ao direito à investigação, mas, de outro, demonstram que há ainda um enorme caminho a percorrer a fim de que a prerrogativa em análise seja plenamente exercitável por seus titulares.

De modo geral, porém, a análise do mais recente Projeto de novo Código de Processo Penal permite afirmar que suas regras objetivaram apagar todos os resquícios autoritários do Código em vigor, imprimindo à legislação infraconstitucional um forte viés democrático, com adoção do princípio acusatório. Em termos de investigação criminal, há notáveis avanços na legislação proposta, os quais, porém, não afastarão a necessidade já verificada nos dias atuais de os operadores do direito interpretarem a lei à luz da 
Constituição Federal e de seus princípios orientadores. Somente assim o direito à investigação, inserido implicitamente no rol de direitos fundamentais do texto constitucional, restará plenamente assegurado. 


\section{BIBLIOGRAFIA}

ABADE, Denise Neves, Garantias do processo penal acusatório - $O$ novo papel do Ministério Público no processo penal de partes, Rio de Janeiro, Renovar, 2005.

ABDO, Helena Najjar, Fundamentos sistemáticos do abuso do processo no direito processual civil, Dissertação de Mestrado apresentada à Faculdade de Direito da Universidade de São Paulo em 2002.

, Observância da regra da objetividade na publicidade do processo realizada pelos meios de comunicação social, Tese de Doutorado apresentada à Faculdade de Direito da Universidade de São Paulo em 2006.

ABELLÁN, Marina Gascón, Los hechos en el derecho - Bases argumentales de la prueba, Barcelona, Marcial Pons, Ediciones Jurídicas e Sociales, 1999.

AFONSO DA SILVA, José, Em face da Constituição Federal de 1988, o Ministério Público pode realizar elou presidir investigação criminal, diretamente? in Revista Brasileira de Ciências Criminais, $n^{\circ}$ 49, São Paulo, Revista dos Tribunais, julho-agosto de 2004.

, Parecer "Controle externo da atividade policial como uma das funções institucionais do Ministério Público - entendimento do art. 129, VII, da Constituição Federal - conteúdo da Lei Complementar e seus limites constitucionais - competências exclusivas das polícias" in Revista ADPESP (Associação dos Delegados de Polícia do Estado de São Paulo), ano 17, nº 22, São Paulo, dezembro de 1996.

ALMEIDA, Joaquim Canuto Mendes de, Princípios fundamentais do processo penal, São Paulo, Revista dos Tribunais, 1973. 
ALMEIDA JR., João Mendes de, O processo criminal brasileiro, vol. I, 4 a ed., São Paulo, Freitas Bastos, 1959.

AMBOS, Kai, Control de la policía por el fiscal versus domínio policial de la instrucción in Revista Jurídica da Escola Superior do Ministério Público de São Paulo, ano I, $\mathrm{n}^{\mathrm{o}} 2$, ESMP, julho-dezembro de 2001.

AMODIO, Ennio, Il processo penale negli Stati Uniti d'America, Milano, Giuffrè Editore, 1988.

, Vitórias e derrotas da cultura dos juristas na elaboração do novo Código de Processo Penal in Revista Brasileira de Ciências Criminais, $n^{\circ} 25$, São Paulo, Revista dos Tribunais, janeiro-março de 1999.

ANDRADE, Manuel da Costa, Sobre as proibições de prova em processo penal, Coimbra, Coimbra Editora, 2006.

ARRUDA, Rejane Alves de, A importância do inquérito policial nos crimes de ação penal privada in Revista Síntese de Direito Penal e Processual Penal, nº 15, São Paulo, Síntese, agosto-setembro de 2002.

BADARÓ, Gustavo Henrique Righi Ivahy, Direito processual penal, Tomo I, Rio de Janeiro, Elsevier, 2008.

, Onus da prova no processo penal, São Paulo, Revista dos Tribunais, 2003.

, Provas atípicas e provas anômalas: inadmissibilidade da substituição da prova testemunhal pela juntada de declarações escritas de quem poderia ser testemunha in 
Estudos em homenagem à Professora Ada Pellegrini Grinover, org. Flávio Luiz Yarshell e Maurício Zanóide de Moraes, São Paulo, DPJ, 2005.

BALDAN, Édson Luís, Investigação defensiva: o direito de defender-se provando in Revista Brasileira de Ciências Criminais, $n^{\circ}$ 64, São Paulo, Revista dos Tribunais, janeirofevereiro 2007.

BARROS, Flaviane de Magalhães, Direito das vítimas e sua participação no processo penal: a análise do PLS 156/2009 a partir de uma interpretação constitucional in O novo processo penal à luz da Constituição (Análise crítica do Projeto de Lei no 156/2009, do Senado Federal), Rio de Janeiro, Lumen Juris, 2010.

BARROS, Marco Antonio de, A busca da verdade no processo penal, Revista dos Tribunais, São Paulo, 2002.

BARROS, Romeu Pires de Campos, Sistema do processo penal brasileiro, vol. I, Rio de Janeiro, Forense, 1987.

BECHARA, Fábio Ramazzini, Da assistência no processo penal in Boletim do Instituto Brasileiro de Ciências Criminais, ano 10, nº 117, agosto de 2002.

BEDAQUE, José Roberto dos Santos, Tutela cautelar e tutela antecipada - tutelas sumárias e tutelas de urgência - Tentativa de sistematização, 5aed., São Paulo, Malheiros, 2006.

BELOTI, Carlos Eduardo Cabral, O Ministério Público e a investigação criminal direta in Revista IOB de Direito Penal e Processual Penal, ano 10, nº 56, junho-julho de 2009. 
BETANHO, Luiz Carlos, Código de processo penal e sua interpretação jurisprudencial, coord. Alberto Silva Franco e Rui Stoco, vol. 2, 2a ed., São Paulo, Revista dos Tribunais, 2004.

BITTENCOURT, Cezar Roberto, A inconstitucionalidade da Resolução $n^{\circ} 13$ do Conselho Nacional do Ministério Público in Boletim do Instituto Brasileiro de Ciências Criminais, ano $14, \mathrm{n}^{\mathrm{o}} 170$, janeiro de 2007.

, A inconstitucionalidade dos poderes investigatórios do Ministério Público in Revista Brasileira de Ciências Criminais, $n^{\circ}$ 66, São Paulo, Revista dos Tribunais, maiojunho de 2007.

BOTTINI, Pierpaolo Cruz, Cautelares: superação da mediocre dicotomia in Boletim do Instituto Brasileiro de Ciências Criminais, ano 18, Edição Especial, agosto de 2010.

BOVINO, Alberto, La participación de la víctima en el procedimiento penal in Revista Brasileira de Ciências Criminais, $n^{\circ}$ 21, São Paulo, Revista dos Tribunais, janeiro-março de 1998.

BUSATO, Paulo César, De magistrados, inquisidores, promotores de justiça $e$ samambaias - Um estudo sobre os sujeitos no processo em um sistema acusatório in $\mathrm{O}$ novo processo penal à luz da Constituição (Análise crítica do Projeto de Lei $n^{0}$ 156/2009, do Senado Federal), Rio de Janeiro, Lumen Juris, 2010.

CABETTE, Eduardo Luiz Santos, O papel do inquérito policial no sistema acusatório - o modelo brasileiro in Revista Brasileira de Ciências Criminais, $n^{\circ} 35$, São Paulo, Revista dos Tribunais, julho-setembro de 2001.

CALMON FILHO, Petrônio, A investigação criminal na reforma do Código de Processo Penal in Revista Brasileira de Ciências Criminais, no 34, São Paulo, Revista dos Tribunais, abril-junho de 2001. 
CAMPOS, Vinício Stein, A força dos grupos de pressão sobre a proposta de mudanças na investigação criminal, na reforma do processo penal brasileiro in Revista A Força Policial, nº 60, São Paulo, outubro-dezembro de 2008.

CARDOSO, Helena Schiessl, O inquérito policial no Anteprojeto do Código de Processo Penal: será possivel abrir mão do defensor no interrogatório policial? in O novo processo penal à luz da Constituição (Análise crítica do Projeto de Lei $n^{\circ}$ 156/2009, do Senado Federal), Rio de Janeiro, Lumen Juris, 2010.

CARNEIRO, Paulo Cezar Pinheiro, O Ministério Público no processo civil e penal: promotor natural - atribuição e conflito, Rio de Janeiro, Forense, 1995.

CARNELUTTI, Francesco, Las miserias del proceso penal, trad. S. S. Melendo, Editorial Temis S.A., Bogotá, 1989.

, Principi del processo penale, Napoli, Morano Editore, 1960.

CARVALHO, Luis Gustavo Grandinetti Castanho de, Quando o público e o privado se encontram no Projeto: assistência, indenização e composição in O novo processo penal à luz da Constituição (Análise crítica do Projeto de Lei n 156/2009, do Senado Federal), Rio de Janeiro, Lumen Juris, 2010.

CASAGRANDE, Renato, A urgência de um novo Código de Processo Penal in Revista de Informação Legislativa, ano 46, nº 183, edição especial, julho-setembro de 2009.

CASTRO FILHO, José Olímpio de, Abuso do direito no processo civil, $2^{\mathrm{a}}$ ed., Rio de Janeiro, Forense, 1960.

CATALANO, Elena Maria, L'abuso del processo, Milano, Giuffrè, 2004. 
CHAIA, Rubén A., La prueba en el proceso penal, Buenos Aires, Hammurabi, 2010.

CHOUKR, Fauzi Hassan, Garantias constitucionais na investigação criminal, $2^{\mathrm{a}}$ ed., Rio de Janeiro, Lumen Juris, 2001.

, O relacionamento entre o Ministério Público e a polícia judiciária no processo penal acusatório in Revista Jurídica da Escola Superior do Ministério Público de São Paulo, ano I, nº 2, ESMP, julho-dezembro de 2001.

CINTRA, Antonio Carlos de Araújo, GRINOVER, Ada Pellegrini e DINAMARCO, Cândido Rangel, Teoria geral do processo, 20ª ed., São Paulo, Malheiros, 2004.

COLOMER, Juan-Luis Gómez, La investigacion criminal: problemas actuales y perspectivas de unificacion internacional in Revista Jurídica da Escola Superior do Ministério Público de São Paulo, ano I, nº 2, ESMP, julho-dezembro de 2001.

COMOGLIO, Luigi Paolo, Prove ed accertamento dei fatti nel nuovo C.P.P. in Rivista Italiana di Diritto e Procedura Penale, ano 33, Milano, Giuffrè Editore, 1990.

COMOGLIO, Luigi Paolo, FERRI, Corrado, e TARUFFO, Michelle, Lezioni sul processo civile, $2^{\mathrm{a}}$ ed., Bologna, Il Mulino, 1998.

CONSO, Giovanni, e GREVI, Vittorio, Compendio di procedura penale: appendice di aggiornamento, Padova, CEDAM, 2001.

COUCEIRO, João Claudio, A garantia constitucional do direito ao silêncio, São Paulo, Revista dos Tribunais, 2004. 
COUTINHO, Jacinto Nelson de Miranda, Ampla defesa e direito à contraprova in Revista Brasileira de Ciências Criminais, nº 55, vol. 13, 2005.

, Anotações pontuais sobre a reforma global do CPP in Boletim do Instituto Brasileiro de Ciências Criminais, ano 18, Edição Especial, agosto de 2010.

, Cada parte no lugar constitucionalmente demarcado in Revista de Informação Legislativa, ano 46, nº 183, edição especial, julho-setembro de 2009.

D’AIUTO, Gianluca, L'estensione all'invesigatore privato delle garanzie di liberta del difensore in Il nuovo ruolo del difensore nel processo penale, coord. Andréa Antonio Dalia e Marzia Ferraioli, Giuffrè Editore, Milano, 2002.

DALIA, Andrea Antonio, Manuale di diritto processuale penale, $4^{\mathrm{a}}$ ed., Padova, CEDAM, 2001 .

DALIA, Gaspare, Il nuovo ruolo del diffensore di ufficio e la disciplina del gratuito patrocínio in Il nuovo ruolo del difensore nel processo penale, coord. Andréa Antonio Dalia e Marzia Ferraioli, Giuffrè Editore, Milano, 2002.

DAMASKA, Mirjan R., I volti della giustizia e del potere - Analisi comparatistica del processo, Bologna, Il Mulino, 1991.

DEZEM, Guilherme Madeira, Da prova penal: tipo processual, provas típicas e atípicas, Campinas, Millenium, 2008.

, Lei do crime organizado in Legislação penal especial, vol. 2, 2a ed., São Paulo, Premier Máxima, 2008. 
DIAS, Jorge de Figueiredo, Direito processual penal, Coimbra, Coimbra Editora, 2004.

DIAS NETO, Theodomiro, O direito ao silêncio: tratamento nos direitos alemão e norteamericano in Revista Brasileira de Ciências Criminais, $\mathrm{n}^{\circ}$ 19, São Paulo, Revista dos Tribunais, julho-setembro de 1997.

DIETER, Maurício Stegemann, O sistema de investigação criminal brasileiro e o novo Código de Processo Penal que se anuncia in $\mathrm{O}$ novo processo penal à luz da Constituição (Análise crítica do Projeto de Lei $n^{\circ}$ 156/2009, do Senado Federal), Rio de Janeiro, Lumen Juris, 2010.

DINAMARCO, Cândido Rangel, $A$ instrumentalidade do processo, $13^{\mathrm{a}}$ ed., São Paulo, Malheiros, 2008.

, Instituições de direito processual civil, vol. III, São Paulo, Malheiros, 2001.

D’URSO, Luiz Flávio Borges, Constituição Federal versus poder investigatório do MP in Revista CEJAP, vol. 6, $\mathrm{n}^{\mathrm{o}}$ 8, 2005.

FERNANDES, Antonio Scarance, O consenso na Justiça penal in Boletim do Instituto Brasileiro de Ciências Criminais, São Paulo, v. 7, n. 83, out. 1999.

, O equilíbrio na investigação criminal in Estudos em Homenagem à Professora Ada Pellegrini Grinover, coord. Flávio Luiz Yarshell e Maurício Zanóide de Moraes, São Paulo, DPJ Editora, 2005.

, O papel da vítima no processo criminal, São Paulo, Malheiros, 1995. 
, Procedimentos do Código originário ao Código projetado in Revista do Advogado, no 113, ano XXXI, setembro de 2011.

, Processo penal constitucional, $6^{\mathrm{a}}$ ed., São Paulo, Revista dos Tribunais, 2010.

, Prova e sucedâneos da prova no processo penal, Revista Brasileira de Ciências Criminais, $n^{\circ}$ 66, vol. 15, 2007.

, Reação defensiva à imputação, São Paulo, Revista dos Tribunais, 2002.

, Teoria geral do procedimento e o procedimento no processo penal, São Paulo, Revista dos Tribunais, 2005.

FERNANDES, Antonio Scarance, E OUTROS, La víctima en el proceso penal - su régimen legal en Argentina, Bolívia, Brasil, Chile, Paraguay, Uruguay, Ediciones de Palma, Buenos Aires, 1997.

FERNANDES, Marcela de Jesus Boldori, A legitimidade investigativa do Ministério Público e a importância de sua investigação no combate ao crime organizado in Boletim Científico ESMPU, ano III, nº 2, Brasília, ESMPU, abril-junho de 2004.

FERNANDES, Og, $O$ habeas corpus no projeto do $C P P$ in Boletim do Instituto Brasileiro de Ciências Criminais, ano 18, Edição Especial, agosto de 2010.

FERRAIOLI, Marzia, e DALIA, Andrea Antonio, Manuale di diritto procesuale penale, $7^{\mathrm{a}}$ ed., Padova, CEDAM, 2010. 
FERRAJOLI, Luigi, Direito e razão - Teoria do garantismo penal, São Paulo, Revista dos Tribunais, 2002.

FERRARI, Eduardo Reale, Código de Processo Penal - Comentários aos projetos de reforma legislativa, São Paulo, Ed. Millenium, 2003.

FERRAZ JR., Tercio Sampaio, Introdução ao estudo do direito - Técnica, decisão, dominação, $4^{\mathrm{a}}$ ed., São Paulo, Atlas, 2003.

FERREIRA, Orlando Miranda, Inquérito policial e o Ato Normativo 314 - PGJ/CPJ in Revista Brasileira de Ciências Criminais, $n^{\circ}$. 45, São Paulo, Revista dos Tribunais, outubro-dezembro de 2003.

FERREIRA, Pinto, Comentários à Constituição Brasileira, vol. II, São Paulo, Saraiva, 1989.

FERREIRA FILHO, Manoel Gonçalves, O poder investigatório do Ministério Público in Boletim do Instituto Manoel Pedro Pimentel, no 23, dezembro de 2004.

FONTES, Paulo Gustavo Guedes, O poder investigatório do Ministério Público in Boletim Científico ESMPU, ano II, nº 8, Brasília, ESMPU, julho-setembro de 2006, p. 135.

FRAGOSO, José Carlos, São ilegais os “procedimentos investigatórios” realizados pelo Ministério Público Federal in Revista Brasileira de Ciências Criminais, no. 37, São Paulo, Revista dos Tribunais, janeiro-março de 2002.

GARCIA, Flúvio Cardinelle Oliveira, Formas alternativas de resolução de conflitos: uma abordagem no âmbito do direito penal e processual penal in Processo penal e garantias constitucionais, coord. Marco Antonio Marques da Silva, São Paulo, Quartier Latin, 2006. 
GATTI, Giustino, Codice di procedura penale annotato com la giurisprudenza, $18^{\mathrm{a}}$ ed., Napoli, Grupo Editoriale Esselibri Simone, 2010.

GIACOMOLLI, Nereu José, A fase preliminar do processo penal - Crises, misérias e novas metodologias investigatórias, Rio de Janeiro, Lumen Juris, 2011.

GOMES, Carla Silene Cardoso Lisboa Bernardo, Inexistência de multa por litigância de má-fé no processo penal in Análise de precedentes criminais do Superior Tribunal de Justiça - Estudos em homenagem à Desembargadora Jane Ribeiro Silva, Belo Horizonte, Ed. Atualizar, 2009.

GOMES FILHO, Antonio Magalhães, A motivação das decisões penais, São Paulo, Revista dos Tribunais, 2001.

, Breves anotações sobre a temática das provas no Projeto de Código de Processo Penal (Projeto $n^{\circ} 156 / 2009$ do Senado Federal) in Revista do Advogado, $\mathrm{n}^{\circ} 113$, ano XXXI, setembro de 2011.

, Direito à prova no processo penal, São Paulo, Revista dos Tribunais, 1997.

, Medidas cautelares da Lei 9.271/96: produção antecipada de provas e prisão preventiva in Boletim do Instituto Brasileiro de Ciências Criminais, $\mathrm{n}^{0}$ 42, junho de 1996.

, Ministério Público e acusação penal no sistema brasileiro in Ministério Público - Pena y Estado, Buenos Aires, Editores del Puerto, 1997. 
, Notas sobre a terminologia da prova (reflexos no processo penal brasileiro)

in Estudos em homenagem à Professora Ada Pellegrini Grinover, org. Flávio Luiz Yarshell e Maurício Zanóide de Moraes, São Paulo, DPJ, 2005.

, O princípio da presunção de inocência na Constituição de 1988 e na Convenção Americana sobre Direitos Humanos - Pacto de São José da Costa Rica in Revista da Associação dos Advogados de São Paulo, nº 42, 1994.

, Princípios gerais da prova no Projeto de Código de Processo Penal in Revista de Informação Legislativa, ano $46, \mathrm{n}^{0}$ 183, edição especial, julho-setembro de 2009.

, Provas - Lei 11.690, de 09.06.2008 in As reformas no processo penal - as novas leis de 2008 e os projetos de reforma, coord. Maria Thereza Rocha de Assis Moura, São Paulo, Revista dos Tribunais, 2008.

GOMES FILHO, Antonio Magalhães e BADARÓ, Gustavo Henrique Righi Ivahy, Prova e sucedâneos de prova no processo penal brasileiro in Revista Brasileira de Ciências Criminais, São Paulo, Revista dos Tribunais, nº 65, março-abril de 2007.

GONÇALVES, Luiz Carlos dos Santos, A atuação criminal do Ministério Público: entre a tradição e a efetividade in Revista Brasileira de Ciências Criminais, $n^{\circ}$ 46, São Paulo, Revista dos Tribunais, janeiro-fevereiro de 2004.

GRECO FILHO, Vicente, Manual de processo penal, 7ª ed., São Paulo, Saraiva, 2009.

GRINOVER, Ada Pellegrini, A iniciativa instrutória do juiz no processo penal acusatório in Revista Brasileira de Ciências Criminais, n² 27, São Paulo, Revista dos Tribunais, 1999. , A marcha do processo, Rio de Janeiro, Forense Universitária, 2000. 
, Interrogatório do réu e direito ao silêncio in Ciência Penal, ano $3, \mathrm{n}^{\circ} 1$, São

Paulo, Ed. Convívio, 1976.

, Investigações pelo Ministério Público in Boletim do Instituto Brasileiro de Ciências Criminais, ano 12, no 145, dezembro de 2004.

, O conteúdo da garantia do contraditório in Novas tendências do direito processual, Rio de Janeiro, Forense Universitária, 1990.

, O processo constitucional em marcha, São Paulo, Max Limonad, 1985.

GRINOVER, Ada Pellegrini, FERNANDES, Antonio Scarance e GOMES FILHO, Antonio Magalhães, As nulidades no processo penal, 11ª ed., São Paulo, Revista dos Tribunais, 2009.

GRINOVER, Ada Pellegrini, FERNANDES, Antonio Scarance, GOMES FILHO, Antonio Magalhães, e GOMES, Luiz Flávio, Juizados especiais criminais: Comentários à Lei 9.099, de 26.09.1995, $5^{\mathrm{a}}$ ed., São Paulo, Revista dos Tribunais, 2005.

GUIMARÃES, João Lopes, A posição do Ministério Público na fase pré-processual e o projeto do código de processo penal in Revista Justitia, v. 60, número especial, 1999.

HAMILTON, Sergio Demoro, A amplitude das atribuições do Ministério Público in Discursos sediciosos - Crime, direito e sociedade, vol. 3, $\mathrm{n}^{\mathrm{o}}$ 5/6, Rio de Janeiro, Freitas Bastos, 1998.

HASSEMER, Winfried, Sobre el abuso de los derechos in Revista de Ciências Jurídicas ¿Más derecho?, n 3, 2003. 
HERNÁNDEZ, Elia Pérez, La constitucionalidad de las pruebas aportadas por los detectives privados in Poder Judicial, no 35, setembro de 1994.

INSTITUTO BRASILEIRO DE DIREITO PROCESSUAL (IBDP), Propostas de emendas ao Projeto de lei de Código de Processo Penal - Substitutivo da CCJ do Senado, Presidência de Ada Pellegrini Grinover, 2010. Disponível on line in http://novo.direitoprocessual.org.br/content/blocos/96/1

INSTITUTO DOS ADVOGADOS BRASILEIROS, Parecer da Comissão Permanente de Direito Penal do Instituto dos Advogados Brasileiros ao Projeto de Lei do Senado $n^{o}$ 156/2009 que institui o novo Código de Processo Penal, coord. Fernando Fragoso, Rio de Janeiro, 2010.

JARDIM, Afrânio Silva, Direito processual penal, 9a ed., Rio de Janeiro, Forense, 2000.

KFOURI FILHO, Abrahão José, Parecer in Revista ADPESP (Associação dos Delegados de Polícia do Estado de São Paulo), ano 17, n 22, São Paulo, dezembro de 1996.

LATTANZI, Giorgio, e LUPO, Ernesto, Codice di procedura penale - Rassegna di giurisprudenza e di dottrina - Atti e prove, Libri II e III, Milano, Giuffrè, 1997.

LIMA, Marcellus Polastri, A prova penal de acordo com a reforma processual penal, $3^{\text {a }}$ ed., Rio de Janeiro, Lumen Juris, 2009.

,O Ministério Público pode ou não investigar? Uma análise de recente decisão do STF, in Revista Brasileira de Ciências Criminais, n 46, São Paulo, Revista dos Tribunais, janeiro-fevereiro de 2004. 
LONGOBARDO, Carlo, Le false dichiarazione al difensore in Il nuovo ruolo del difensore nel processo penale, coord. Andréa Antonio Dália e Marzia Ferraioli, Giuffrè Editore, Milano, 2002.

LOPES, Fábio Motta, A impossibilidade de o Ministério Público investigar no âmbito criminal in Revista CEJ (Conselho de Estudos Judiciários), vol. 13, n 47, 2009.

LOPES JR. Aury, A opacidade da discussão em torno do promotor investigador (mudem os inquisidores, mas a fogueira continuará acesa) in Boletim do Instituto Brasileiro de Ciências Criminais, ano 12, nº 142, setembro de 2004.

, Introdução crítica ao processo penal (fundamentos da instrumentalidade garantista), 4ª ed., Rio de Janeiro, Lumen Juris, 2006.

, Sistemas de investigação preliminar no processo penal, Rio de Janeiro, Lumen Juris, 2001.

LORUSSO, Sergio, Provvedimenti "allo stato degli atti" e processo penale di parti, Milano, Giuffrè Editore, 1995.

MACHADO, André Augusto Mendes, Investigação criminal defensiva, São Paulo, Revista dos Tribunais, 2010.

MACHADO, Antonio Claudio da Costa, Tutela antecipada, São Paulo, Oliveira Mendes, 1998.

MACHADO, Luiz Alberto, Palestra “Conversa com a Polícia Judiciária” realizada no IV Congresso Nacional de Delegados de Polícia de Carreira em Foz do Iguaçu, a 09/10/1996 in Revista ADPESP (Associação dos Delegados de Polícia do Estado de São Paulo), ano 17, no 22, São Paulo, dezembro de 1996. 
MACHADO, Nelio Roberto Seidl, Notas sobre a investigação criminal, diante da estrutura do processo criminal no estado de direito democrático in Discursos sediciosos Crime, direito e sociedade, vol. 3, nº 5/6, Rio de Janeiro, Freitas Bastos, 1998.

MAIER, Julio B. J., Derecho procesal penal, Tomo II, Parte General - Sujetos procesales, Buenos Aires, Editores del Puerto, 2003.

MALATESTA, Nicola Framarino dei, A lógica das provas em matéria criminal, trad. Waleska Girotto Silverberg, vol. I, Conan Editora, 1995.

MANZINI, Vincenzo, Tratado de derecho procesal penal, vol. 2, Buenos Aires, Ediciones Jurídicas Europa-América, 1951.

MARCHI, Eduardo Cesar Silveira, Guia de metodologia jurídica (teses, monografias e artigos), Itália, Edizioni del Grifo, 2001.

MARQUES, José Frederico, Elementos de direito processual penal, vol. I e II, $2^{\mathrm{a}}$ ed., Campinas, Millenium, 2000.

MAZZILli, Hugo Nigro, As investigações do Ministério Público para fins penais in Revista Magister de Direito Penal e Processual Penal, ano 1, nº 5, 2005. , Regime jurídico do Ministério Público, $5^{\mathrm{a}}$ ed., São Paulo, Saraiva, 2001.

MEDAUAR, Odete, Direito administrativo moderno, $9^{\text {a }}$ ed., São Paulo, Revista dos Tribunais, 2005. 
MIRABETE, Julio Fabbrini, Código de processo penal interpretado, $11^{\mathrm{a}}$ ed., São Paulo, Atlas, 2006.

, Processo penal, $17^{\mathrm{a}}$ ed., São Paulo, Atlas, 2005.

MIRANDA, Pontes de, Comentários ao Código de Processo Civil, t. XII, Rio de Janeiro, Forense, 1973.

MITTERMAIER, Karl Joseph Anton, Tratado de la prueba en materia criminal, trad. Primitivo González del Alba, Buenos Aires, Hammurabi, 2006.

MONTE, Elio lo, Il delitto di rivelazione di segretti inerenti ad un procedimento penale in Il nuovo ruolo del difensore nel processo penale, coord. Andréa Antonio Dalia e Marzia Ferraioli, Giuffrè Editore, Milano, 2002.

MORAES, Alexandre de, Constituição do Brasil Interpretada e legislação constitucional, $7^{a}$ ed., São Paulo. Atlas, 2007.

, Direito constitucional, 24 ed., São Paulo, Atlas, 2009.

MORAES, Maurício Zanóide de, Esgrimando com o professor Sérgio Marcos de Moraes Pitombo: os inexistentes poderes investigatórios criminais do Ministério Público in Revista do Advogado, $n^{\circ} 78$, ano XXIV, setembro de 2004.

, Quem tem medo do "juiz das garantias"? in Boletim do Instituto Brasileiro de Ciências Criminais, ano 18, Edição Especial, agosto de 2010. 
MORAIS FILHO, Antonio Evaristo de, O Ministério Público e o inquérito policial in Revista Brasileira de Ciências Criminais, $n^{0}$ 19, São Paulo, Revista dos Tribunais, julhosetembro de 2007.

MOSSIN, Heráclito Antonio, Aspectos relevantes no projeto de reforma do Código de Processo Penal em tema de investigação in Revista CEJAP, ano 3, $\mathrm{n}^{\circ}$, novembro de 2002.

MOURA, Maria Thereza Rocha de Assis, Os sistemas de persecução penal e seus órgãos de acusação in Criminalia, $\mathrm{n}^{\circ}$ 2, vol. 69, 2003.

MOURA, Maria Thereza Rocha de Assis, e MORAES, Maurício Zanóide de, Direito ao silêncio no interrogatório in Revista Brasileira de Ciências Criminais, $\mathrm{n}^{\mathrm{o}}$ 6, São Paulo, Revista dos Tribunais, abril-junho de 1994.

NAPPI, Aniello, Guida breve alla procedura penale, 2a ed., Milano, Giuffrè, 2004.

NOGUEIRA, Carlos Frederico Coelho, O Ministério Público pode investigar delitos in Boletim do Instituto Manoel Pedro Pimentel, $\mathrm{n}^{\mathrm{o}}$ 21, ano IV, julho-agosto-setembro de 2002.

NORONHA, Edgar Magalhães, Curso de direito processual penal, $27^{\mathrm{a}}$ ed., São Paulo, Saraiva, 1999.

NUCCI, Guilherme de Souza, A investigação criminal e a atuação do Ministério Público in Revista CEJAP, vol. 5, $n^{\circ}$ 7, 2004.

, Código de processo penal comentado, 9ª ed., São Paulo, Revista dos Tribunais, 2009. 
, Manual de processo penal e execução penal, $2^{\mathrm{a}}$ ed., São Paulo, Revista dos Tribunais, 2006.

, O valor da confissão como meio de prova no processo penal, São Paulo, Revista dos Tribunais, 1997.

OLIVEIRA, Francisco da Costa, A defesa e a investigação do crime, $2^{\mathrm{a}}$ ed. Coimbra, Almedina, 2008.

OLIVEIRA, Rodrigo Tadeu Pimenta, A investigação direta pelo Ministério Público e o sistema acusatório in Revista de Direito Militar, $\mathrm{n}^{\mathrm{o}}$ 75, janeiro-fevereiro de 2009.

PACHECO, Denilson Feitoza, Investigação criminal pelo Ministério Público in Boletim do Instituto de Ciências Penais, vol. 4, nº 60, 2005.

PASCHOAL, Janaína Conceição, Breves apontamentos relativos ao instituto do plea bargaining no direito norte-americano in Revista do curso de direito do Centro Universitário das Faculdades Metropolitanas Unidas, São Paulo, v. 15, n. 23, 2001.

PEDROSO, Fernando de Almeida, Processo penal - o direito de defesa: repercussão, amplitude e limites, $3^{\mathrm{a}}$ ed., São Paulo, Revista dos Tribunais, 2001.

PELUSO, Vinicius de Toledo Pisa, Revelia e produção antecipada da prova testemunhal in Revista Brasileira de Ciências Criminais, nº 72, v. 16, 2008.

PINHO, Rodrigo César Rebello, Participação no Painel "O Ministério Público e a Investigação Criminal” do Seminário Propostas para um Novo Modelo de Persecução Criminal - Combate à Impunidade, Série Cadernos do CEJ, nº 25, Brasília, CJF, 2005. 
PIOVESAN, Flávia, A incorporação, a hierarquia e o impacto dos tratados internacionais de proteção dos direitos humanos no direito brasileiro in $\mathrm{O}$ sistema interamericano de proteção dos direitos humanos e o direito brasileiro, coord. Luiz Flávio Gomes e Flávia Piovesan, São Paulo, Revista dos Tribunais, 2000.

, Reforma do Judiciário e direitos humanos in Reforma do Judiciário analisada e comentada - Emenda Constitucional 45/2004, coord. André Ramos Tavares, Pedro Lenza e Pietro de Jesús Alarcón, São Paulo, Método, 2005.

PISANI, Mario, MOLARI, Alfredo, PERCHINUNNO, Vincenzo, e CORSO, Piermaria, Manuale di procedura penale, Bologna, Monduzzi, 1994.

PRADO, Geraldo, Sistema acusatório - A conformidade constitucional das leis processuais penais, $4^{\mathrm{a}}$ ed., Rio de janeiro, Lumen Juris, 2006.

, Sobre o Projeto de Código de Processo Penal in Revista de Informação Legislativa, ano 46, nº 183, edição especial, julho-setembro de 2009.

QUEIJO, Maria Elizabeth, O direito de não produzir prova contra si mesmo (o princípio nemo tenetur se detegere e suas decorrências no processo penal), São Paulo, Saraiva, 2003.

QUIROGA, Jacobo López Barja de, Tratado de derecho procesal penal, Navarra, Aranzadi, 2004.

RAHAL, Flávia, Questões gerais da reforma do Código de Processo Penal in Revista do Advogado, no 113, ano XXXI, setembro de 2011. 
RAMOS, João Gualberto Garcez, A tutela de urgência no processo penal brasileiro, Belo Horizonte, Del Rey, 1998.

RANGEL, Paulo, Direito processual penal, 10를 ed., Rio de Janeiro, Lumen Juris, 2005.

RASCOVSKI, Luiz, Investigação criminal defensiva: uma luz no fim do túnel com sua previsão no novo Código de Processo Penal (Projeto de Lei 156/09) in Boletim do Instituto Brasileiro de Ciências Criminais, $\mathrm{n}^{\mathrm{o}}$ 219, fevereiro de 2011.

REALE JÚNIOR, Miguel, O crime de desobediência e os processos investigatórios do Ministério Público in Boletim do Instituto Manoel Pedro Pimentel, $\mathrm{n}^{\mathrm{o}} 18$, ano outubro-novembro-dezembro de 2001.

RIBEIRO, Diego Diniz, A intervenção do Ministério Público na investigação criminal: a figura do promotor-investigador in Boletim do Instituto Brasileiro de Ciências Criminais, ano $10, \mathrm{n}^{\mathrm{o}} 121$, dezembro de 2002.

RUIZ FILHO, Antonio, Observações sobre o novo processo penal in Revista do Advogado, $\mathrm{n}^{\mathrm{o}}$ 113, ano XXXI, setembro de 2011.

SAAD, Marta, O direito de defesa no inquérito policial, São Paulo, Revista dos Tribunais, 2004.

SANTIN, Valter Foleto, O Ministério Público na investigação criminal, Bauru, Edipro, 2001.

SARLET, Ingo Wolfgang, A eficácia dos direitos fundamentais, 9ªed., Porto Alegra, Livraria do Advogado, 2008. 
SCHOLZ, Leônidas Ribeiro, e KEHDI, André Pires de Andrade, Cabimento de perícia em sede de justificação prévia de natureza criminal in Boletim do Instituto Brasileiro de Ciências Criminais, $\mathrm{n}^{\mathrm{o}}$ 177, agosto de 2007.

SILVA, Aloísio Firmo Guimarães, ARAÚJO, Maria Emilia Moraes de e CORRÊA, Paulo Fernando, A investigação criminal direta pelo Ministério Público in Boletim do Instituto Brasileiro de Ciências Criminais, ano , nº6, maio de 1998.

SILVA, Ovídio A. Baptista da, Comentários ao Código de Processo Civil, vol. XI, 2ª ed., Porto Alegre, Letras Jurídicas, 1986.

SIRACUSANO, Delfino, Manuale di diritto processuale penale, vol. 1, Milano, Giuffrè, 1990.

SOUZA, José Barcelos de, A defesa na polícia e em juizo: teoria e prática do processo

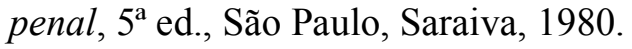

, Dificuldades na prática do direito: produção antecipada de prova e prova ad perpetuam memoriam, com a reforma processual penal de 2008, artigo ainda no prelo, a ser publicado em obra jurídica em homenagem ao Professor Sérgio Demoro Hamilton, pela Editora Lumen Juuris, Rio de Janeiro apud MARCELLUS POLASTRI LIMA, A prova penal de acordo com a reforma processual penal, $3^{\text {a }}$ ed., Rio de Janeiro, Lumen Juris, 2009.

, Investigação direta pelo Ministério Público in Revista Brasileira de Ciências Criminais, n 44, São Paulo, Revista dos Tribunais, julho-setembro de 2003.

SOUZA, Luiz Sergio Fernandes, Abuso de direito processual - uma teoria pragmática, São Paulo, Revista dos Tribunais, 2005. 
STOCO, Rui, Abuso do direito e má-fé processual, São Paulo, Revista dos Tribunais, 2002.

STRECK, Lenio Luiz e FELDENS, Luciano, Crime e Constituição - A legitimidade da função investigatória do Ministério Público, Rio de Janeiro, Forense, 2003.

SUANNES, Adauto, Os fundamentos éticos do devido processo penal, São Paulo, Revista dos Tribunais, 1999.

SZAFIR, Alexandra Lebelson, Competência para justificação prévia preparatória de revisão criminal in Boletim do Instituto Brasileiro de Ciências Criminais, $\mathrm{n}^{\mathrm{o}}$ 37, janeiro de 1999.

TARUFFO, Michelle, Il diritto alla prova nel processo civile in Rivista di Diritto Processuale, Padova, CEDAM, n. 39, v. 77, janeiro-março de 1984.

, La prueba de los hechos, Madrid, Ed. Trotta, 2002.

, Simplesmente la verdad - El juez y la construcción de los hechos, trad. Daniela Accatino Scagliotti, Madrid, Marcial Pons, 2010.

THEODORO JÚNIOR, Humberto, Processo cautelar, 22ª ed., São Paulo, Liv. e Ed. Universitária de Direito, 2005.

TONINI, Paolo, A prova no processo penal italiano, trad. Alexandra Martins e Daniela Mróz, São Paulo, Revista dos Tribunais, 2002.

, Direito de defesa e prova científica: novas tendências do processo penal italiano in Revista Brasileira de Ciências Criminais, ano 12, no 48, maio-junho de 2004. 
, Manuale breve - Diritto processuale penale, Milano, Giuffrè, 2009.

TORNAGHI, Hélio, Comentários ao Código de Processo Penal, Rio de Janeiro, Revista Forense, 1956.

TORON, Alberto Zacharias, Inquérito só no MP e bye, bye ação penal privada in Boletim do Instituto Brasileiro de Ciências Criminais, ano 18, Edição Especial, agosto de 2010.

TOURINHO FILHO, Fernando da Costa, Código de processo penal comentado, $13^{\mathrm{a}}$ ed., São Paulo, Saraiva, 2010. , Processo Penal, 31ª ed., vol. 2, São Paulo, Saraiva, 2009.

TUCCI, Rogério Lauria, Investigação criminal no projeto de reforma do Código de Processo Penal in Revista do Advogado, nº 78, ano XXIV, setembro de 2004. , Ministério Público e investigação criminal, São Paulo, Revista dos Tribunais, 2004.

, Persecução penal, prisão e liberdade, São Paulo, Saraiva, 1980.

, Teoria do direito processual penal - Jurisdição, ação e processo penal (estudo sistemático), São Paulo, Revista dos Tribunais, 2002.

UBERTIS, Giulio, Il contradittorio nella formazione della prova penale in Estudos em homenagem à Professora Ada Pellegrini Grinover, org. Flávio Luiz Yarshell e Maurício Zanóide de Moraes, São Paulo, DPJ, 2005. 
, La ricerca della verità giudiziale in La conoscenza del fatto nel processo penale, Milano, Giuffrè, 1992.

VENTURA, Pasquale, Le indagine difensive, Milano, Giuffrè, 2005.

VIEIRA, Ana Lúcia Menezes, Processo penal e mídia, São Paulo, Revista dos Tribunais, 2003.

VIEIRA, Luís Guilherme, O Ministério Público e a investigação criminal in Revista Brasileira de Ciências Criminais, $n^{\circ} 46$, São Paulo, Revista dos Tribunais, janeiro-fevereiro de 2004.

VIEIRA, Renato Stanziola, Ainda, investigação criminal direta do Ministério Público: poder implícito ou limite explícito? Proposta de novo enfoque in Boletim do Instituto Brasileiro de Ciências Criminais, ano 17, nº 199, junho de 2009.

, Procedimento investigatório criminal, esse outro desconhecido in Boletim do Instituto Brasileiro de Ciências Criminais, ano 14, n 168 , novembro de 2006.

YARSHELL, Flávio Luiz, Antecipação da prova sem o requisito da urgência e direito autônomo à prova, São Paulo, Malheiros, 2009.

ZEHR, Howard, Trocando as lentes - um novo foco sobre o crime e a Justiça, São Paulo, Palas Athena, 2008.

ZILLI, Marcos Alexandre Coelho, A iniciativa instrutória do juiz no processo penal, São Paulo, Revista dos Tribunais, 2003. 
, Atuação investigatória do Ministério Público: um convite à reflexão in Boletim do Instituto Manoel Pedro Pimentel, no 23, dezembro de 2004.

ZIYADE, Fátima, O assistente da acusação, Porto Alegre, Livraria do Advogado, 1993. 


\section{RESUMO}

O presente trabalho aborda a investigação criminal como um direito das partes, decorrente do próprio direito à prova, assegurado implicitamente pela Constituição Federal de 1988. Mais do que a fase inicial da persecução penal, a investigação é um verdadeiro direito das possíveis partes de um futuro processo (Ministério Público, imputado e vítima), exercitável para inúmeros fins: busca de fontes de prova que poderão ensejar a produção dos respectivos meios de prova na fase instrutória, colheita de elementos de informação para embasar a propositura da ação penal e evitar seu ajuizamento equivocado e desnecessário, fundamento para as decisões judiciais proferidas nesta etapa de instrução preliminar, subsídio para as partes traçarem suas respectivas estratégias de atuação ao longo da persecução penal, entre outros.

O reconhecimento do direito à investigação no plano teórico, no entanto, não reproduz as conseqüências práticas esperadas no processo penal brasileiro. A falta de regulamentação legal acerca dos modos de exercício de tal direito, verificada no ordenamento jurídico em vigor, acaba por tolher sua eficácia. Logo, a fim de que o direito à investigação seja plenamente assegurado em nosso País, necessária se faz a criação de normas que reconheçam expressamente e disciplinem às minúcias o procedimento para a realização das investigações por cada uma das diferentes partes do processo penal. 


\section{RIASSUNTO}

Il presente studio analizza l'indagine penale come um diritto delle parti, derivato del proprio diritto alla prova, implicitamente garantito dalla Costituzione del 1988. Più che la fase iniziale del procedimento penale, l'indagine è veramente un diritto delle possibile parti di un futuro processo (Pubblico Ministero, imputato e offeso), esercitabile per vari fini: ricerca di fonti di prova per l'assunzione dei mezzi di prova nella fase probatoria, raccolta di elementi infomativi per l'esercizio dell'azione penale o per evitare questa quando inutile, fondamento per le decisioni giudiziale nella prima fase del procedimento, supporto per le parti delineare le loro strategie di azione lungo il procedimento, tra le altre.

Il riconoscimento del diritto all'indagine in teoria, tuttavia, non reproduce le conseguenze pratiche previste nel processo penale brasiliano. La mancanza di regolamentazione giuridica verso i mezzi di esercizio di questo diritto nel sistema legale vigente toglie la sua efficacia. Per garantire pienamente il diritto all'indagine in nostro Paese, c'è bisogno di creare regole che riconoscono esplicitamente e disciplinano in

dettagli il procedimento per lo svolgimento dell'indagine per ciascuna delle diverse parti del processo penale. 